\title{
BASELINE RISK ASSESSMENT OF GROUND WATER CONTAMINATION at THE URANIUM MiLl TaILINGS Site Near Naturita, Colorado
}

\section{August 1995}

\author{
ran \\ $\operatorname{OeT} 1 \mathrm{dt} ;$ \\ $0 \operatorname{sic}$
}

\section{DISCLAIMER}

This report was prepared as an account of work sponsored by an agency of the United States Government. Neither the United States Government nor any agency thereof, nor any of their employees, makes any warranty, express or implied, or assumes any legal liability or responsibility for the accuracy, completeness, or usefulness of any information, apparatus, product, or process disclosed, or represents that its use would not infringe privately owned rights. Reference herein to any specific commercial product, process, or service by trade name, trademark, manufacturer, or otherwise does not necessarily constitute or imply its endorsement, recommendation, or favoring by the United States Government or any agency thereof. The views and opinions of authors expressed herein do not necessarily state or reflect those of the United States Government or any agency thereof.

DISTRIBUTION OF THIS DOCUMENT IS UNLIRITEY) (h)

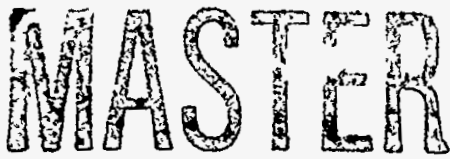


This report has been reproduced from the best available copy. Available in paper copy and microfiche.

Number of pages in this report: 190

DOE and DOE contractors can obtain copies of this report from:

Office of Scientific and Technical Information

P.O. Box 62

Oak Ridge, TN 37831

(615) $576-8401$

This report is publicly available from:

National Technical Information Service

Department of Commerce 5285 Port Royal Road

Springfield, VA 22161

(703) 487-4650 


\section{DISCLAIMER}

Portions of this document may be illegible in electronic image products. Images are produced from the best available original document. 
DOE/AL/62350-195

REV. 0

BASELINE RISK ASSESSMENT OF GROUND WATER CONTAMINATION AT THE

URANIUM MILL TAILINGS SITE NEAR NATURITA, COLORADO

August 1995

Prepared for

U.S. Department of Energy

Environmental Restoration Division

UMTRA Project Team

Albuquerque, New Mexico

Prepared by

Jacobs Engineering Group Inc.

Albuquerque, New Mexico 


\section{CITIZENS' SUMMARY}

\section{INTRODUCTION}

The Uranium Mill Tailings Remedial Action (UMTRA) Project consists of the Surface Project (phase I), and the Ground Water Project (phase II). For the UMTRA Project site located near Naturita, Colorado (the Naturita site), phase I involves the removal of radioactively contaminated soils and materials and their transportation to a disposal site at Union Carbide Corporation's Upper Burbank Repository at Uravan, Colorado, about 13 road miles (mi) (21 kilometers [km]) to the northwest. The surface cleanup will reduce radon and other radiation emissions from the former uranium processing site and prevent further siterelated contamination of ground water. No uranium mill tailings are involved because the tailings were removed from the Naturita site and placed at Coke Oven, Colorado, during 1977 to 1979.

Phase II of the project will evaluate the nature and extent of ground water contamination resulting from uranium processing and its effect on human health or the environment; and will determine site-specific ground water compliance strategies in accordance with the U.S. Environmental Protection Agency (EPA) ground water standards established for the UMTRA Project. Human health risks could occur from drinking water pumped from a hypothetical well drilled in the contaminated ground water area. Environmental risks may result if plants or animals are exposed to contaminated ground water, or surface water that has received contaminated ground water. Therefore, a risk assessment is conducted for the Naturita site.

Risk assessment is the process of describing a source of contamination, showing how that contamination may reach the public and the environment, calculating the amount of contamination exposure, and characterizing possible health or environmental effects that may result from this exposure.

This risk assessment report is the first site-specific document prepared for the Ground Water Project at the Naturita site. What follows is an evaluation of current and possible future impacts to the public and the environment from exposure to contaminated ground water. The results of this evaluation and further site characterization will be used to determine whether any action is needed to protect human health or the environment.

\section{RISK SUMMARY}

There are currently no human health risks associated with the contaminated ground water, because no one uses the water from the Naturita site area for drinking, bathing, irrigating, or livestock watering. This situation will continue if land and water use near the Naturita site does not change. Since changes of land use may or may not create future risks, when determined, these specific land uses should be evaluated to identify potential health and environmental risks from the contaminated ground water or surface water.

There are currently no impacts to plants or animals from contaminated ground water discharging to the surface. However, vegetation growing in the flowing spring and 
floodplain areas may be taking up contaminants directly from the upper aquifer. The amount of this contamination, if any, is not known.

Because future land use at the Naturita site is not known, this risk assessment is conservative and evaluates a hypothetical worst-case scenario. This scenario places a hypothetical well in the most contaminated portion, the alluvial (upper) aquifer. In this situation, this hypothetical well would be the sole source of water for drinking, bathing, livestock watering, and irrigating crops. Drinking this ground water could cause health problems to this future population. Livestock, crops, and wildlife could also suffer ill effects. Based on the findings of this scenario, the water from the upper aquifer should not be used; and all other site water should be evaluated before it is used.

\section{GROUND WATER QUALITY}

\section{Background ground water quality}

Background ground water quality is the ground water quality in the area if uranium milling activities had not occurred. Two aquifers are present in the vicinity of the Naturita site: a shallow upper aquifer at approximately 3 to 18 feet (ft) (1 to 5.5 meters [m]) below land surface, and a deeper sandstone aquifer, the Salt Wash (lower) aquifer, at a depth of about $170 \mathrm{ft}(52 \mathrm{~m})$ below land surface. These two aquifers are separated by a low permeability rock unit (the Brushy Basin member) primarily composed of permeability shale and mudstone.

The upper aquifer is a source of potable water about $1.5 \mathrm{mi}(2.4 \mathrm{~km})$ upgradient of the Naturita site. The ground water in the upper aquifer does not move into the lower aquifer due to the upward ground water pressure in the lower aquifer. The natural ground water in the lower aquifer contains arsenic, molybdenum, selenium, uranium, and radium (-226 and -228 ). These result from naturally occurring uranium mineralization in the lower aquifer.

\section{Site-related ground water quality}

Arsenic, manganese, molybdenum, sodium, sulfate, vanadium, and uranium are the main contaminants in the upper aquifer resulting from the uranium processing at the Naturita site. This contamination appears to extend some distance off-site toward the northwest; discharges into the San Miguel River, where it is quickly diluted; and discharges to the surface from a flowing spring located near the Naturita site. The full extent of the contamination has not been determined.

\section{HUMAN HEALTH RISK ASSESSMENT}

\section{Methods}

This risk assessment starts by identifying constituents present in ground water contaminated by the uranium milling process. This is done by comparing water quality data from wells drilled on the Naturita site to water quality data collected from background 
wells. The next step is to examine possible human health problems that could result from drinking water containing these contaminants.

Both current and possible future human health risks are evaluated. To evaluate current possible risks, it must be determined whether anyone is now drinking the ground water. To evaluate possible future risks, it is assumed that a drinking water well is drilled into the most contaminated area under the Naturita site, and that people are getting all their drinking water from this well. To evaluate possible future risks from the spring, it is assumed that children could drink the water and eat the sediment while playing in the flowing spring and floodplain areas.

Health risks, other than cancer, were specially evaluated for children, because the ratio of contaminant to body weight is greater for children. Thus, children 1 to 10 years old would be the most likely to experience health problems from drinking contaminated water. Infants, 0 to 1 year, generally drink less water than children, but they are sensitive to contaminants, like sulfate. The health risks from contact with the spring were evaluated for older children ( 9 to 10 year olds), because they are likely to play in the flowing spring and floodplain areas. Cancer risks were evaluated for adults, because cancer takes a long time to develop.

The seriousness of possible health effects varies because the levels of contaminants in ground water vary from one well sampling round to the next; people vary in their body weight and in their consumption of water. People also vary in how their bodies react to chemical exposures. These differences are all considered in this risk assessment whenever possible.

This risk assessment provides the graphs that show the different exposure levels that might occur, and the most current scientific information on the types of health effects that may result from the hypothetical exposure.

\section{Results}

Because no one uses the contaminated ground water from the Naturita site area for drinking, bathing, irrigating, or livestock watering, there are currently no health problems occurring from it. This situation will continue if water use near the Naturita site does not change.

It is unlikely that people will use the contaminated ground water from the aquifer for drinking in the future, because of the availability of a municipal water supply system in the town of Naturita. Nevertheless, based on current concentrations of contaminants found in the most contaminated ground water, there are possible health risks associated from drinking this water. Table CS-1 provides information on the nature of possible health problems that could be expected.

Only people whose sole drinking water comes from a well placed in the most contaminated portion of the upper aquifer (a fraction of the Naturita site) would be expected to experience the health problems described in Table CS-1. Therefore, the table provides the upper limit of possible risks; real future risks would probably be lower. 
Table CS-1 Human health effects from drinking site-affected contaminated ground water from the upper aquifer, Naturita, Colorado, site

\begin{tabular}{|c|c|c|}
\hline Contaminant & Short-term & Long-term \\
\hline Arsenic & None & $\begin{array}{l}\text { Excess lifetime cancer risk } \\
\text { exceeds the maximum } \\
\text { recommended by EPA as } \\
\text { acceptable; other health problems } \\
\text { not expected. }\end{array}$ \\
\hline Manganese & None & $\begin{array}{l}\text { Mild neurological symptoms } \\
\text { include memory loss, irritability, } \\
\text { and muscle rigidity. }\end{array}$ \\
\hline Molybdenum & None & Copper deficiency anemia. \\
\hline Sodium & None & Hypertension in sensitive people. \\
\hline Sulfate & $\begin{array}{l}\text { Diarrhea, particularly in } \\
\text { infants }\end{array}$ & None. \\
\hline Uranium & None & $\begin{array}{l}\text { Health problems not expected } \\
\text { from chemical toxicity; increased } \\
\text { lifetime cancer risk exceeds the } \\
\text { maximum recommended by EPA } \\
\text { as acceptable. }\end{array}$ \\
\hline Vanadium & Diarrhea & Green tongue. \\
\hline \multicolumn{3}{|c|}{$\begin{array}{l}\text { These effects could vary from person to person depending on the amount of water a } \\
\text { person drinks, body weight, dietary habits, and individual sensitivities such as the } \\
\text { preexisting kidney, liver, or heart diseases, and other factors. }\end{array}$} \\
\hline
\end{tabular}

The most notable possible health hazard in this ground water is sulfate. Ingestion of sulfate in the amounts found in the ground water, particularly by infants, could cause diarrhea. However, these sulfate levels make the water taste and smell very unpleasant, discouraging use. The vanadium levels present in the contaminated ground water could increase the severity of sulfate-caused diarrhea.

Mild health problems could result from the other contaminants if people were to drink the ground water obtained from a hypothetical domestic well located in the most contaminated portion of the upper aquifer for a long time. The manganese levels could affect the nervous system, causing mental disturbances, memory loss, muscle rigidity, or tremors. The molybdenum levels could result in copper deficiency. The sodium levels could lead to hypertension in sensitive people and high blood pressure. These health problems could be worse in people who have kidney problems. In addition, the increased lifetime cancer risk from arsenic and uranium may exceed the maximum acceptable value recommended by the EPA.

Although people could incidentally come into contact with the spring, based on available data, no health problems would be expected from such contact. Furthermore, human 
health would not be affected from eating meat or drinking milk from cattle grazed near or watered from the flowing spring.

\section{ECOLOGICAL AND LIVESTOCK RISK ASSESSMENT}

\section{Methods}

The ecological risk assessment presented in this document is a screening level assessment that relies on limited environmental sampling and literature information. The field of ecological risk assessment has many uncertainties because of limited scientific knowledge, such as the lack of information on how some chemicals affect plants and animals. Also, the impact of a mixture of chemicals on plants and animals is poorly understood.

The possible effects of the above mentioned site-related contaminants on grazing livestock, wildlife, and crops are evaluated using comparisons. These contaminant concentrations in ground water and surface water, sediment, and plants are compared to available guidelines from regulatory agencies and literature values. The areas evaluated include surface water and sediment in the flowing spring area located on the floodplain of the San Miguel River northwest of the Naturita site. The upper aquifer ground water is also evaluated assuming plant roots extending into the upper aquifer take up the most contaminated ground water. In addition, this risk assessment examines the use and impact of this ground water as a sole source for watering livestock and irrigating crops, as well as its for possible impact on wildlife.

\section{LIVESTOCK AND AGRICULTURAL RESULTS}

There are currently no health risks to cattle and crops from the contaminated ground water in the upper aquifer, since cattle are not currently grazed or watered on or around the Naturita site, and agricultural crops are not currently irrigated with the contaminated ground water. Possible effects to grazing horses that eat vegetation growing into the San Miguel River floodplain northwest of the Naturita site could not be determined. If some day, the contaminated ground water from the upper aquifer under the Naturita site is used as a sole drinking water source for cattle or sheep, long term exposure to high levels of selenium, and vanadium could harm these animals. This water should not be used for irrigation because manganese, molybdenum, selenium, sodium, and vanadium could harm agricultural crops. In addition, selenium, molybdenum, manganese, and vanadium could concentrate in plants and enter the food chain. The flowing spring water is safe for livestock watering.

\section{ECOLOGICAL RESULTS}

Vegetation growing above the upper aquifer may have roots extending into the shallow contaminated ground water. Based on literature values, the levels of some contaminants such as arsenic, manganese, and vanadium found in the contaminated ground water, may be concentrated by plants. Therefore, these elements could affect plants and could enter the foodchain. However, it has not been determined with existing data whether or not plant species growing at the Naturita site could be harmed by these contaminant levels. 
If the most contaminated ground water from the upper aquifer were used in the future to create a pond, the levels of chloride, manganese, selenium, silver, and vanadium could have negative effects on plants and animals. Although the spring water is safe for animals, arsenic and manganese have accumulated in the sediment below the spring and could harm aquatic plants and animals.

\section{CONCLUSIONS}

Ground water site-related contamination below the Naturita site is limited to the upper aquifer. This aquifer extends downgradient to the San Miguel River channel about $3500 \mathrm{ft}$ $(1100 \mathrm{~m})$ north of the former mill yard. There are no domestic wells in this aquifer on or near the Naturita site now, and cattle are not grazing there. Based on limited sampling, there are currently no human health risks associated with Naturita site contaminated ground water or from contaminated ground water discharging to the surface in the form of a flowing spring. However, the high levels of contaminants in sediment below the flowing spring may harm aquatic plants and animals.

This risk assessment has determined that there could be certain health problems in people and livestock if in the future site-related contaminated ground water were used for drinking. The contaminated ground water could also be harmful to plants with roots in the most contaminated portion of the upper aquifer or to plants irrigated with the contaminated ground water. Therefore, no one should drink the water; livestock should not be permitted to graze on the grasses growing. on the Naturita site until the possible risks to livestock are evaluated; and contaminated ground water should not be used for irrigation.

The Naturita site evaluation is ongoing and will include further characterization of ground water quality, water levels, and ground water movement. In addition, sampling of surface water, sediment, and plants will be considered in future work plans. This risk assessment and future investigations will be used to determine how to deal with the contaminated ground water. In addition, if specific plans for land use at the Naturita site are determined, the possible risks from the ground water to human health or the environment should be evaluated. 


\section{TABLE OF CONTENTS}

Section

Page

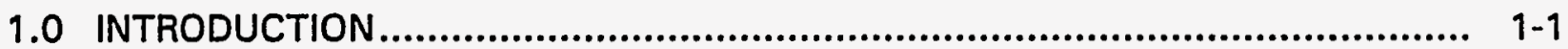

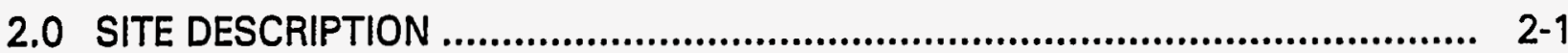

2.1 Site background ......................................................................... 2-1

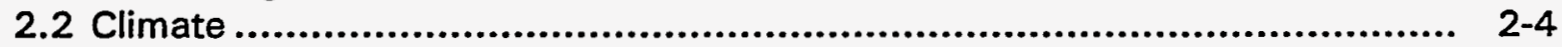

2.3 Physiographic setting.............................................................. $2-4$

2.4 Geology and hydrogeology ............................................................ 2-6

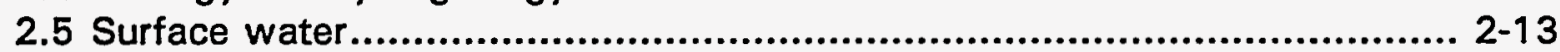

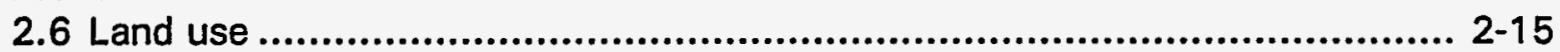

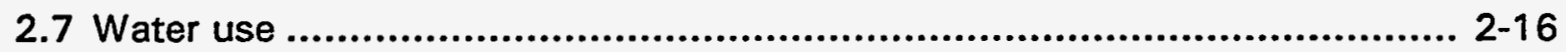

3.0 MAGNITUDE AND EXTENT OF CONTAMINATION $\ldots \ldots \ldots \ldots \ldots \ldots \ldots \ldots \ldots \ldots \ldots \ldots . . . . \ldots \ldots \ldots$

3.1 Background water quality summary.................................................. $3-9$

3.2 Magnitude of site-related contamination ............................................ $3-9$

3.3 Statistical analysis of ground water quality ........................................ 3-15

3.4 Contaminants of potential concern ................................................ 3-16

3.5 Contaminant fate and transport ..................................................... 3-18

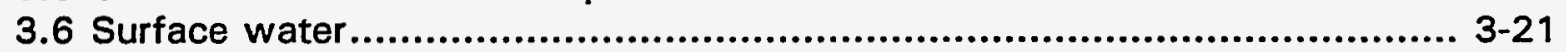

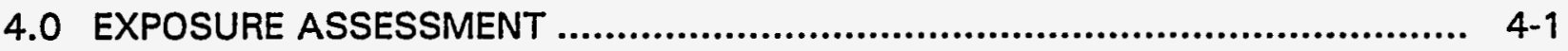

4.1 Potentially exposed population....................................................... 4-1

4.2 Exposure pathways ................................................................... $4-3$

4.2.1 Ground water exposure pathways........................................... 4-4

4.2.2 Floodplain exposure pathways ................................................. 4-7

4.3 Exposure concentrations ............................................................. 4-7

4.3.1 Ground water ................................................................... 4-7

4.3.2 Spring water, associated sediment and plants............................ 4-8

4.4 Estimation of intake..................................................................... 4-11

4.4.1 Ground water ingestion pathway ............................................... 4-11

4.4.2 Floodplain exposure pathways .................................................. 4-15

4.5 Exposure assessment uncertainties .............................................. 4-19

5.0 TOXICITY ASSESSMENT .............................................................. $\quad 5-1$

5.1 Contaminant toxicity summaries................................................... $5-1$

5.1 .1 Antimony .................................................................... $5-1$

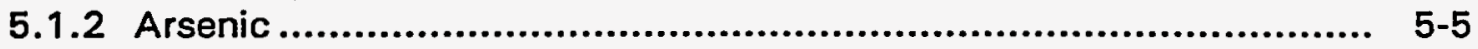

5.1 .3 Manganese .................................................................. $5-8$

5.1.4 Molybdenum................................................................. 5-13

5.1 .5 Selenium ........................................................................ 5-15

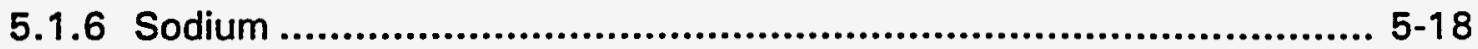

5.1 .7 Sulfate.......................................................................... 5-21

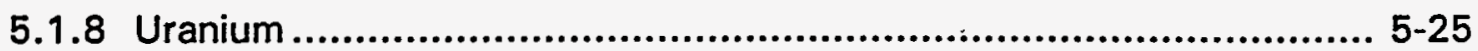

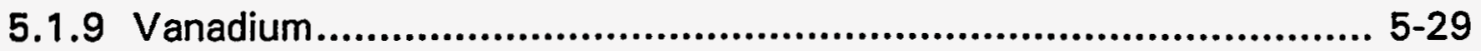

5.2 Contaminant interactions ........................................................... 5-33 


\section{TABLE OF CONTENTS (Concluded)}

Section

Page

5.3 Contaminant risk factors

6.0 HUMAN HEALTH RISK EVALUATION

6.1 Potential noncarcinogenic health effects

6.1.1 Alluvial ground water potential use

6.1.2 Floodplain spring water potential use.

6.2 Potential carcinogenic health effects

6.3 Limitations of human risk evaluation

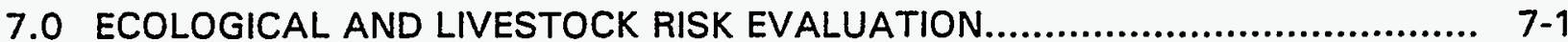

7.1 Exposure pathways ................................................................ $7-1$

7.2 Ecological receptors .............................................................. $7-2$

7.2.1 Terrestrial resources....................................................... $7-2$

7.2.2 Aquatic resources ....................................................... $7-5$

7.2.3 Threatened and endangered species........................................ 7-6

7.3 Contaminants of potential ecological concern and ecological risk............... $7-7$

7.3.1 San Miguel River ................................................................. 7-7

7.3.2 Other surface water bodies ................................................... 7-7

7.3.3 Alluvial ground water....................................................... 7-12

7.4 Potential agricultural and livestock impacts ..................................... 7-17

7.5 Limitations of the ecological risk assessment ................................... 7-18

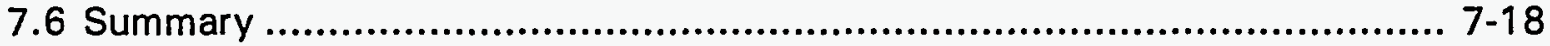

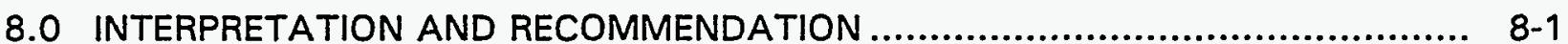

8.1 Risk summary .................................................................... $8-1$

8.2 Limitations of this risk assessment.............................................. $8-2$

8.3 Ground water criteria........................................................... $8-4$

8.4 Risk mitigation measures .......................................................... 8-6

8.5 Recommendations.............................................................. $8-7$

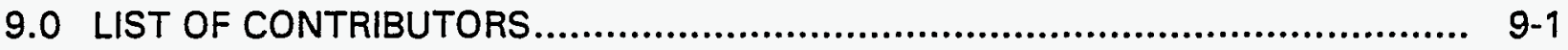

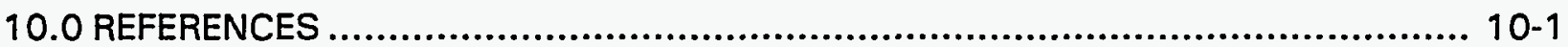




\section{LIST OF FIGURES}

2.1 Location of Naturita, Colorado, site

2.2 Aerial photograph, Naturita, Colorado, site .............................................. 2-3

2.3 San Miguel River floodplain, Naturita, Colorado, site.................................... 2-5

2.4 Rocks and hydrogeologic units present in the Naturita area, Naturita, Colorado, site

2.5 Locations of active and abandoned monitor wells, Naturita, Colorado, site

2.6 Ground water table elevation in the alluvial aquifer and trend of hydrogeologic cross-section, Naturita, Colorado, site

2.7 Hydrogeological cross section A-A', Naturita, Colorado, site

2.8 Location of private wells, Naturita, Colorado, site

3.1 Major element classification of ground water from DOE monitor wells, Naturita, Colorado, site

3.2 Chloride isopleth map, Naturita, Colorado, site ........................................ 3-12

3.2 Uranium isopleth map, Naturita, Colorado, site ........................................ 3-13

3.4 Hydrogeological cross-section A-A' showing the distribution of uranium concentration, Naturita, Colorado, site.

3.5 Surface water and sediment sampling locations, Naturita, Colorado, site.

4.1 Conceptual model, Naturita, Colorado, site.

4.2 Human exposure pathway interactions, Naturita, Colorado, site .................... 4-5

4.3 Probability distributions for tap water ingestion rates, Naturita, Colorado, site..... 4-13

4.4 Probability distributions for body weight, Naturita, Colorado, site.................... 4-14

5.1 Antimony toxicity ranges, Naturita, Colorado, site..................................... 5-4

5.2 Arsenic toxicity ranges, Naturita, Colorado, site...................................... 5-10

5.3 Manganese toxicity ranges, Naturita, Colorado, site ................................. 5-14

5.4 Molybdenum toxicity ranges, Naturita, Colorado, site ................................ 5-16

5.5 Selenium toxicity ranges, Naturita, Colorado, site .................................... 5-19

5.6 Sodium toxicity ranges, Naturita, Colorado, site........................................ 5-22

5.7 Sulfate toxicity ranges, Naturita, Colorado, site ....................................... 5-26

5.8 Half-lives and emissions from decay chain of uranium-238, Naturita,

Colorado, site

5.9 Uranium toxicity ranges, Naturita, Colorado, site ..................................... 5-30

5.10 Vanadium toxicity ranges, Naturita, Colorado, site .................................... 5-34

6.1 Health effects of potential sulfate exposure ranges for infants, Naturita,

Colorado, site

6.2 Health effects of potential vanadium exposure ranges for children, Naturita, Colorado, site

6.3 Health effects of potential manganese exposure ranges for children, Naturita, Colorado, site

6.4 Health effects of potential sodium exposure ranges for children, Naturita, Colorado, site 


\section{LIST OF FIGURES (Concluded)}

Figure

Page

6.5 Health effects of potential molybdenum exposure ranges for children, Naturita, Colorado, site

6.6 Health effects of potential uranium exposure ranges for children, Naturita, Colorado, site

6.7 Health effects of potential arsenic exposure ranges for children, Naturita, Colorado, site

6.8 Health effects of potential antimony exposure ranges for children, Naturita, Colorado, site

6.9 Health effects of potential selenium exposure ranges for children, Naturita, Colorado, site

7.1 Sampling locations and riparian plant communities, Naturita, Colorado, site

7.2 Concentrations of manganese and zinc (a) and arsenic, uranium, and vanadium (b) in sediment and vegetation I pond 538, Naturita, Colorado, site 


\section{LIST OF TABLES}

Table

Page

2.1 Summary of information on private wells within 2-mi $(3-\mathrm{km})$ downgradient and upgradient of the Naturita, Colorado, site.

3.1 Comparison of background and on-site ground water quality in the alluvial aquifer, and downgradient spring water quality, Naturita, Colorado, site (July 1989 to April, 1994, filtered water samples)....................................... 3-2

3.2 DOE monitor well information, Naturita, Colorado, site ................................ 3-8

3.3 Contaminants of potential concern, Naturita, Colorado, site .......................... 3-17

3.4 Stable species of contaminants of potential concern in the ground water system at the Naturita, Colorado, site.

3.5 Comparison of upstream and downstream water quality data for constituents above background in ground water, San Miguel River, Naturita, Colorado, site.... 3-23

3.6 Sediment quality data, Naturita, Colorado, site, November 1994 ..................... 3-29

3.7 Results of mass balance calculations showing calculated changes in concentrations of contaminants of potential concern into the San Miguel River attributable to ground water flowing from the Naturita, Colorado, site

4.1 Concentration probability distributions for the chemical contaminants of potential concern in the alluvial aquifer, Naturita, Colorado, site

4.2 Exposure concentration for the spring water, sediment, and plants (November 1994 sampling round), Naturita, Colorado, site

4.3 Intake probability distributions for the chemical contaminants of potential concern in the alluvial aquifer, Naturita, Colorado, site

4.4 Exposure dose calculations and equation definitions for the hypothetical, incidental ingestion of spring water and sediment by children on the floodplain, Naturita, Colorado, site

4.5 Exposure dose calculations and equation definitions for future hypothetical adult meat and milk consumption from cattle grazed and watered on the floodplain area, Naturita, Colorado, site

5.1 Toxicity values: potential carcinogenic effects....................................... 5-9

5.2 Toxicity values: potential noncarcinogenic effects................................... 5-37

6.1 Calculation of excess lifetime cancer risks from ingestion of ground water, Naturita, Colorado, site 6-14

7.1 Fish species recorded in the San Miguel River at the Naturita, Colorado, site ...... 7-5

7.2 Concentrations of constituent in plants collected in November 1994 from six locations into the San Miguel River at the Naturita, Colorado, site

7.3 Sediment to plant bioconcentration factors for six sampling locations along the San Miguel River near the Naturita, Colorado, site

7.4 Water, sediment, and vegetation analysis at pond 538 near the Naturita, Colorado, site 


\section{LIST OF TABLES (Concluded)}

Table

Page

7.5 Contaminants of potential concern in the alluvial aquifer, Naturita, Colorado, site.

8.1 Concentration limits of constituents for the ground water, Naturita, Colorado, site .............................................................................................. 8 $8-5$ 


\section{LIST OF ACRONYMS}

Acronym

ALC
BLM
'C
DHHS
DOE
DW
EA
EPA
ER-L
ER-M
OF
HEAST
IRIS
LOAEL
MCL
NCP
NEPA
NOAA
NOAEL
RFD
SAR
SF
UMTRA
UMTRCA
USGS
VCA

\section{Definition}

alternate concentration limits Bureau of Land Management degrees celsius Department of Health and Human Services U.S. Department of Energy dry weight environmental assessment U.S. Environmental Protection Agency effects range-low effects-range median degrees Fahrenheit Health Effects Assessment Summary Tables Integrated Risk information System lowest-observed-adverse-effect level Maximum concentration limit National Contingency Plan National Environmental Policy Act National Oceanic and Atmospheric Administration no-observed-adverse-effect level reference dose sodium adsorption ratio slope factor Uranium Mill Tailings Remedial Action Uranium Mill Tailings Radiation Control Act U.S. Geological Survey Vanadium Corporation of America 


\subsection{INTRODUCTION}

The purpose of this baseline risk assessment (this risk assessment) is to determine whether ground water contamination at the Naturita, Colorado, uranium mill tailings site (the Naturita site) could adversely affect human health or the environment. The Naturita site is one of 24 designated uranium mill tailings sites undergoing remediation in accordance with the requirements of the Uranium Mill Tailings Radiation Control Act (UMTRCA) (42 USC $\$ 7901$ et seq.) under the oversight of the U.S. Department of Energy (DOE) Uranium Mill Tailings Remedial Action (UMTRA) Project. The uranium mill tailings (the tailings) were removed from the Naturita site during 1977 to 1979 and were stabilized at Coke Oven, Colorado. The remediation of the remaining surface contamination at the Naturita site started in August 1994. These residual contaminated soils and materials will be removed and contained in a disposal cell at Union Carbide Corporation's Upper Burbank Repository at Uravan, Colorado (the Uravan site), about 13 road miles (mi) (21 kilometers [km]) to the northwest.

This risk assessment is a baseline assessment in the sense that it describes current ground water conditions at the Naturita site; ground water contamination has only been partially characterized. This document evaluates the present and future potential for human health or environmental risk that may need attention. This risk assessment is based on available ground water data for the Naturita site (the former tailings pile and former mill yard areas). Major exposure pathways have been identified and examined for this risk assessment.

This risk assessment follows the basic framework outlined by the U.S. Environmental Protection Agency (EPA) (EPA, 1989a) for evaluating hazardous waste sites to assess potential health and environmental impacts. This risk assessment framework consists of the following steps:

- Data evaluation.

- Combining existing data from various site investigations.

- Comparing sample results with background and tailings source data.

- Selecting appropriate chemical data for this risk assessment.

- Exposure assessment.

- Characterizing exposure settings.

- Identifying exposure pathways.

- Quantifying exposure.

- Toxicity assessment.

- Identifying toxicity values.

- Evaluating noncarcinogenic effects.

- Evaluating carcinogenic effects from radionuclides and chemical carcinogens. 
- Public health risk characterization.

- Comparing toxicity ranges to predicted exposure ranges.

- Combining risks across exposure pathways and multiple contaminants.

- Characterizing uncertainties.

- Environmental risk.

- Characterizing potential biota exposure pathways.

- Identifying potential ecological receptors.

- Evaluating environmental risk qualitatively.

This risk assessment framework is incorporated in the methodology developed to evaluate current human health risk at UMTRA Project sites and to estimate risks from possible future use of contaminated ground water or surface water near the former Naturita site (DOE, 1994a).

This risk assessment will support decisions made for the UMTRA Ground Water Project. The DOE was authorized to conduct ground water remediation under the 1988 UMTRCA Amendments Act (42 USC $\$ 7922$ et seq.) and will determine site-specific ground water compliance strategies for each site. This risk assessment provides information to assist in determining the site-specific ground water compliance strategy for the Naturita site. 


\subsection{SITE DESCRIPTION}

The Naturita site is in the southwestern portion of Colorado, in Montrose County, and about $2 \mathrm{mi}(3 \mathrm{~km})$ northwest of the town of Naturita along Colorado State Highway 141 (Figure 2.1). The Naturita site is on the west bank of the San Miguel River.

\subsection{SITE BACKGROUND}

The Naturita plant was built by the Rare Metals Company in 1930, although operations did not start until 1939, after being purchased and refitted by Vanadium Corporation of America (VCA) for vanadium production (Merritt, 1971).

In 1942 the Naturita plant was altered again to process vanadium as well as uranium. The first shipments of uranium concentrates began in 1947; the Naturita plant was shut down in 1958.

During 1961 to 1963 the VCA operated an upgrader plant making a sand-slime separation at the Naturita site (Merritt, 1971). The slime concentrates were shipped to Durango, Colorado, for further treatment. From 1947 to 1963 the Naturita plant processed 704,000 tons $(639,000$ tonnes) of uranium-vanadium ore (FB\&D, 1981).

During the period 1939 to 1942 a salt-roast and water-leaching process was used for vanadium recovery. Water for the process was obtained from the San Miguel River (FB\&D, 1981). After 1942 both uranium and vanadium were extracted by salt roasting, followed by carbonate leaching in percolation tanks. Carbonate leach tails were slurried to the western half of the Naturita site, north of the former mill yard area (DOE, 1995a). The extractions of uranium and vanadium at this point were usually less than 80 percent. To increase the efficiency of the process, the carbonate-residues were sent to a second stage of sulfuric acid percolation leaching. As a result, an additional 15 to 20 percent of the uranium and vanadium were extracted. A small amount of ammonium sulfate was used at this point as a purifying measure (DOE, 1995a). Acid leach tails were deposited to the east of the Naturita site between the former mill yard and the San Miguel River (DOE, 1995a). Figure 2.2 shows the Naturita site during its operating period.

The tailings were removed from the Naturita site to a heap-leach reprocessing plant located along State Highway 90 , about $3 \mathrm{mi}(5 \mathrm{~km})$ southeast of the intersection of Highways 90 and 141 at Coke Oven during 1977 to 1979. After being reprocessed, the tailings were stabilized at that location with 2 to 10 feet (ft) 10.6 to 3 meters [m]) of cover. In the late 1970 s to early 1980 s, a portion of the Naturita site was leased to General Electric Company for a uranium orebuying station (DOE, 1994b). 


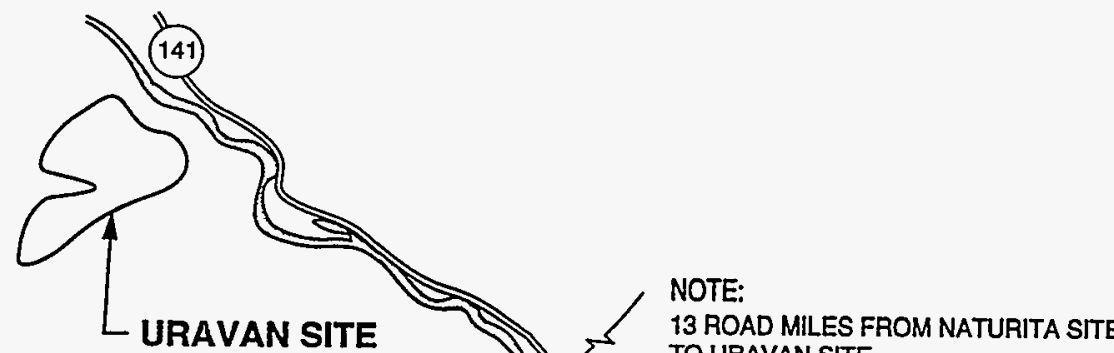

TO URAVAN SITE

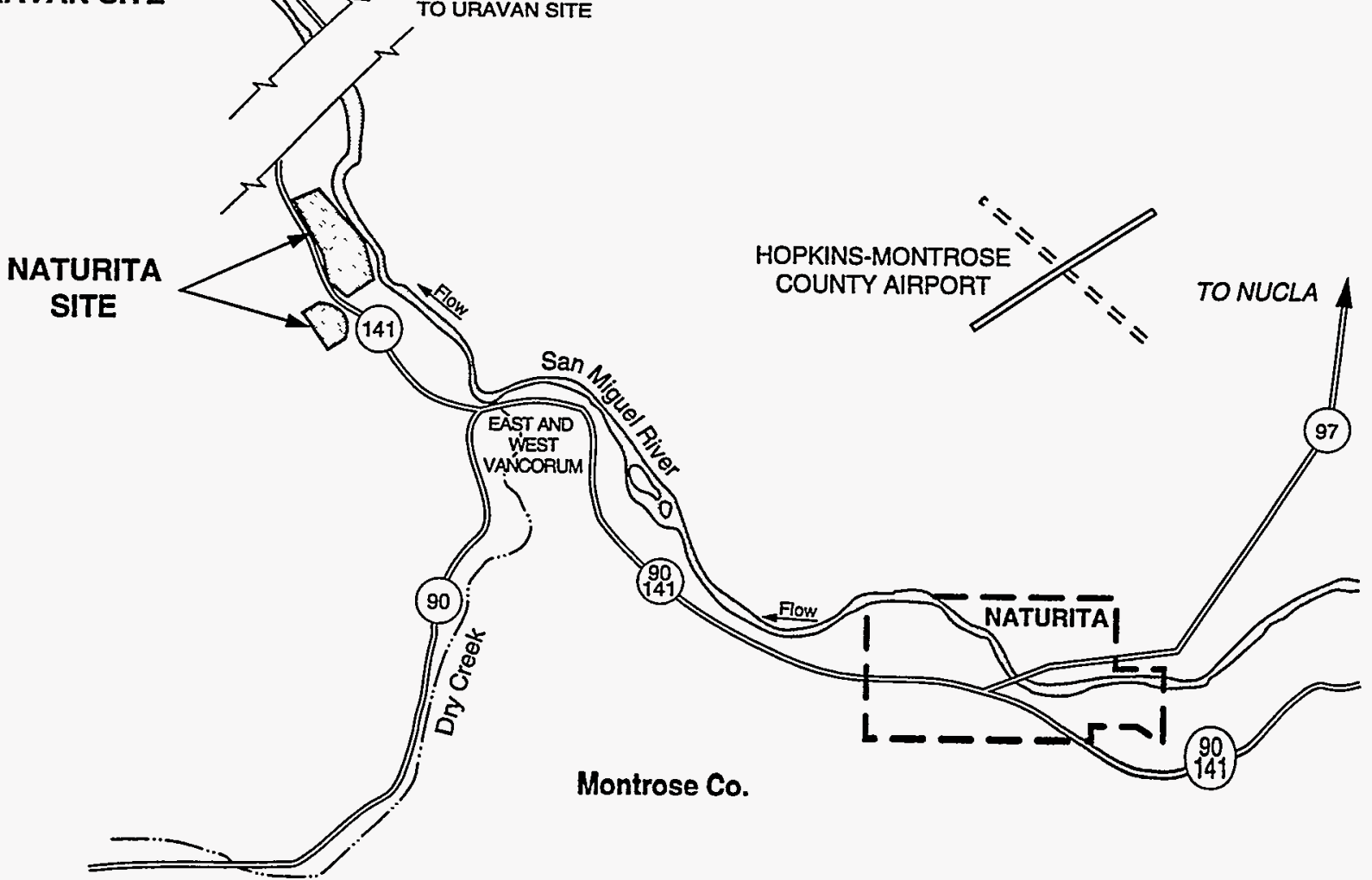

LEGEND

NOT TO SCALE

90) STATE HIGHWAY

EPHEMERAL STREAM

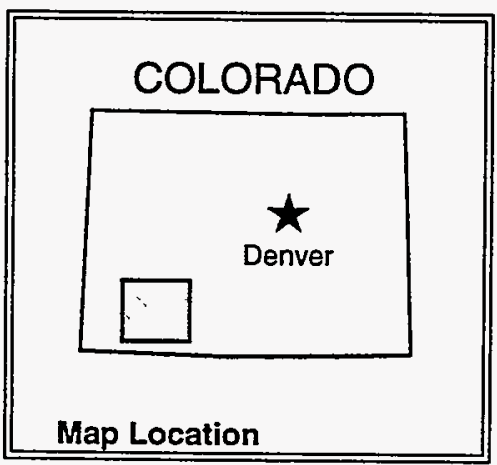

MODIFIED FROM DOE, 1994.

FIGURE 2.1

LOCATION OF NATURITA, COLORADO, SITE 


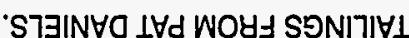

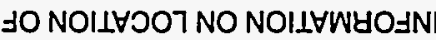

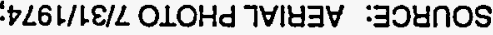

\section{ヨLIS ‘Oव}

Hd $\forall$ y

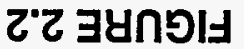

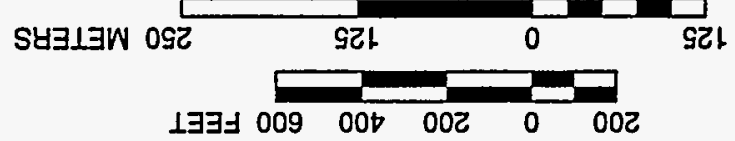

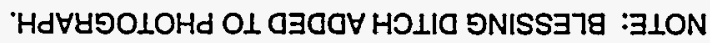

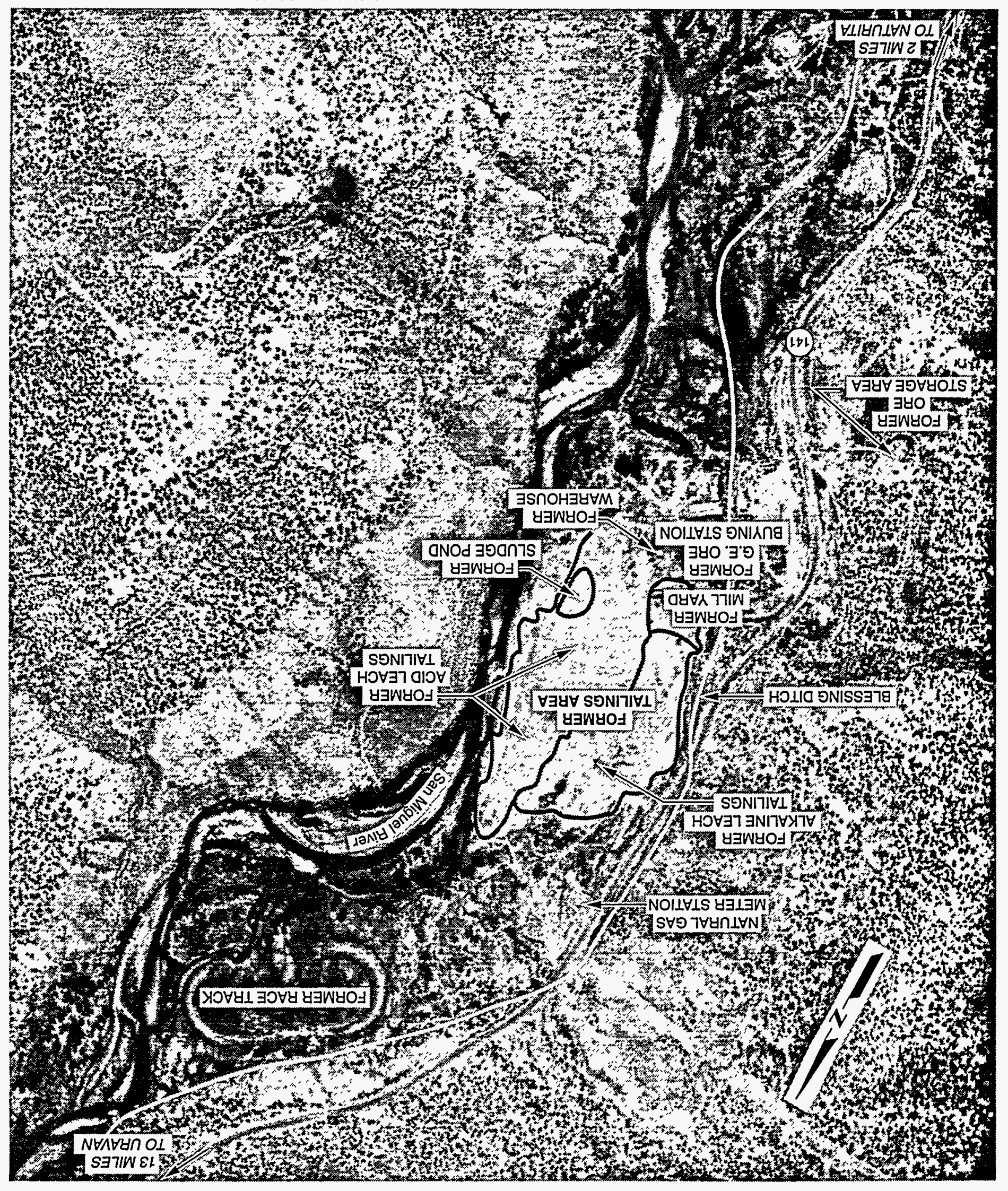


The remaining contaminated material includes about 117,000 cubic yards $\left(\mathrm{yd}^{3}\right)$ $\left(89,500\right.$ cubic meters $\left.\left[\mathrm{m}^{3}\right]\right)$ of sub-tailings and contaminated soil from the former tailings pile area, about $115,000 \mathrm{yd}^{3}\left(87,900 \mathrm{~m}^{3}\right)$ of contaminated soil in the former mill yard and about $8000 \mathrm{yd}^{3}\left(6,000 \mathrm{~m}^{3}\right)$ of demolition debris, about $12,000 \mathrm{yd}^{3}\left(9200 \mathrm{~m}^{3}\right)$ of contaminated soil from the former ore storage area, and about $295,000 \mathrm{yd}^{3}\left(226,000 \mathrm{~m}^{3}\right)$ of windblown and other contaminated material from vicinity properties (DOE, 1994b).

Surface remedial action at the Naturita site started in August 1994 and should be completed by 1997. Residual contaminated soils and materials will be transported to the Uravan site (Figure 2.1) and contained in a disposal cell.

After the remedial action, the Naturita site will be backfilled with clean fill material, recontoured to promote surface drainage, and revegetated (DOE, 1994c). Then the Naturita site will be released for development or other uses.

\subsection{CLIMATE}

The climate of the Naturita site area is semiarid continental with low precipitation and humidity, large temperature variations, and high evaporation (DOE, 1994c). The annual precipitation is approximately 13 inches (33 centimeters [cm]), with most precipitation occurring from July through October. The annual snowfall is about 30 to 32 inches $(80$ to $81 \mathrm{~cm})$. The annual potential evapotranspiration is less than 24 inches $(61 \mathrm{~cm})$ (Water Information Center, 1973).

Prevailing winds are from north-northwest (down-valley) and south-southeast (up-valley) with the average wind speed below 7 miles per hour (6 knots) (DOE, $1994 \mathrm{c}$ ). The average daily high temperature is 65 degrees Fahrenheit ( ${ }^{\circ} \mathrm{F}$ ) (18 degrees Celsius $\left.\left[{ }^{\circ} \mathrm{C}\right]\right)$, and the average daily low temperature is $36^{\circ} \mathrm{F}\left(2^{\circ} \mathrm{C}\right)$.

\subsection{PHYSIOGRAPHIC SETTING}

The Naturita site is located in the Canyonlands section of the Colorado Plateau physiographic province (Fenneman, 1946). The Canyonlands section is characterized by deeply incised drainages and isolated mesas. The Naturita site is within the San Miguel River valley at an elevation of about $5300 \mathrm{ft}(1600 \mathrm{~m})$ above sea level.

The present course of the San Miguel River generally coincides with the axis if the Nucla syncline, a major structural feature of the area (Ackerman and Rush, 1984). The Nucla syncline plunges gently to the northwest.

The Naturita site is situated on a northwest trending portion of the San Miguel River floodplain (see Figure 2.3) and is bordered to the east and northeast by the San Miguel River and to the west and southwest by the northeast flank of Sawtooth Ridge (USGS, 1979). 


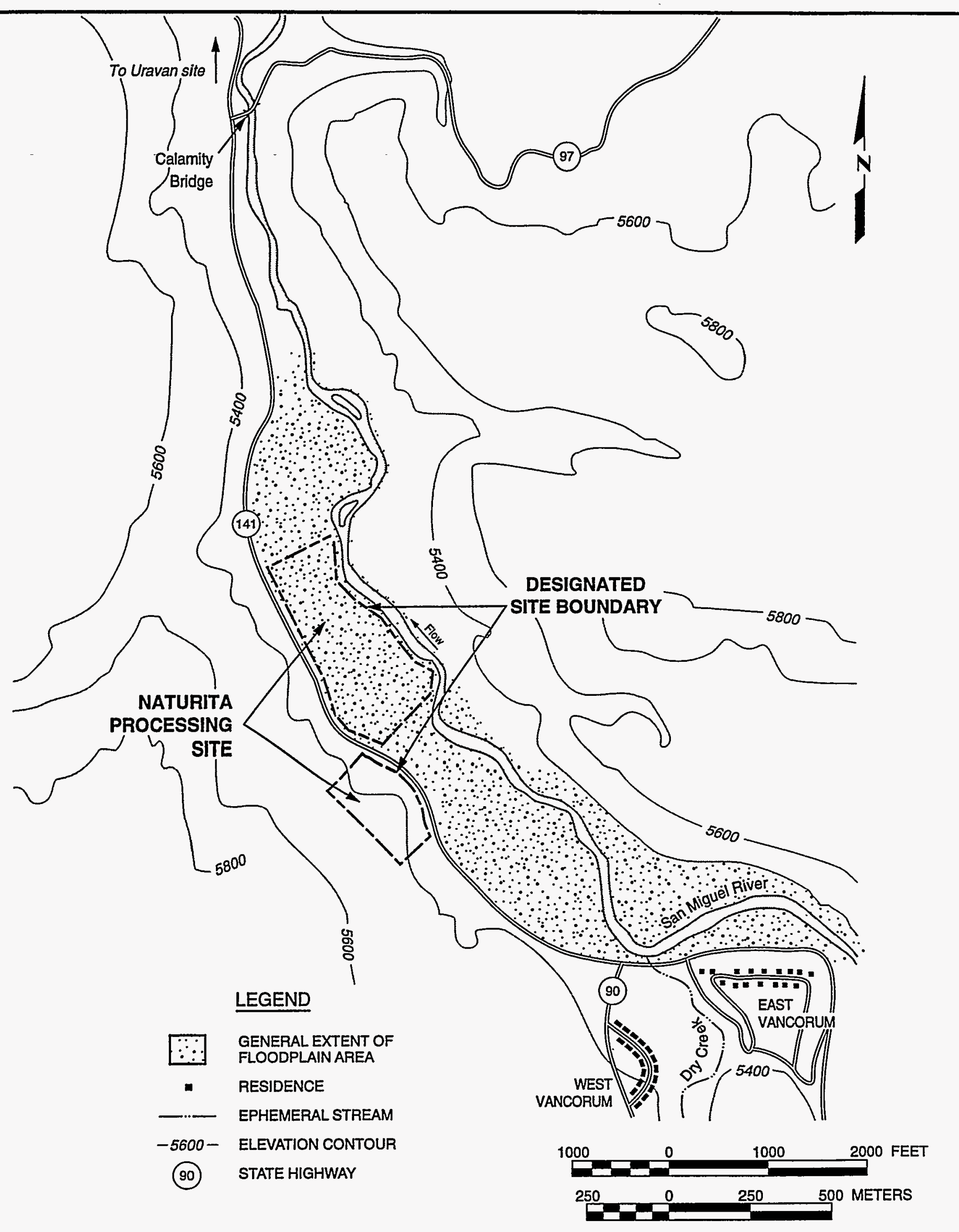

FIGURE 2.3

SAN MIGUEL RIVER FLOODPLAIN NATURITA, COLORADO, SITE 
The Naturita site is underlain by unconsolidated surficial deposits consisting of narrow strips of Quaternary floodplain and river terrace deposits along the incised river valleys. The Quaternary is underlain by rock units consisting of a thick sequence of Jurassic continental and marine rocks consisting of sandstone, shale, and limestone. Figure 2.4 shows the regionally significant rock and hydrogeologic units present in the area.

The Naturita site is underlain by unconsolidated alluvial deposits and fill material consisting of river gravel and cobbles in a silty to clayey sand matrix. The alluvium ranges in thickness from 11 to $34 \mathrm{ft}(3.4$ to $10 \mathrm{~m})$, with an average thickness of $20 \mathrm{ft}(6 \mathrm{~m})$. The alluvium is underlain by rocks of the Morrison Formation consisting of shales, fine- to very fine-grained sandstones, conglomerates of the Brushy Basin Member and fine- to coarse-grained sandstones and shales of the Salt Wash Member. The Brushy Basin Member has a maximum thickness of $490 \mathrm{ft}(150 \mathrm{~m})$. At the Naturita site, the top of the Salt Wash Member is encountered at depths of 130 to $165 \mathrm{ft}(40$ to $50 \mathrm{~m}$ ) below ground surface. These units dip 2 to 4 degrees to the northeast.

The Brushy Basin Member and the Salt Wash Member of the Morrison Formation are part of the regionally significant Mesozoic sandstone aquifer (Figure 2.4) (Weir et al., 1984).

\section{Alluvial Aquifer}

At the Naturita site, unconfined ground water occurs in the Quaternary alluvium (alluvial aquifer) at depths ranging from 3 to $18 \mathrm{ft}(1$ to $5.5 \mathrm{~m}$ ) below ground surface. Currently there are six DOE monitor wells (monitor wells) completed within the alluvial aquifer at the Naturita site. Monitor wells 546, 547, and 549 monitor upgradient locations, monitor wells 505 and 506 are located in the former tailings pile and former mill yard areas respectively, and monitor well 548 is located downgradient of the former tailings pile area. In late 1992, six monitor wells $(616,619,630,632,637$, and 656) were removed or destroyed prior to the initiation of surface remedial action. Figure 2.5 shows the locations of active and abandoned monitor wells at the Naturita site.

To aid in the assessment of potential points of exposure via ground water use, it is important to understand the configuration of the alluvial aquifer and the interaction between ground water and surface water. The general configuration of the alluvial aquifer is controlled by the depositional extent and saturated thickness of the alluvium within the San Miguel River drainage.

To the west, the alluvial aquifer is bounded by the rocks of the Brushy Basin Member which forms the lower canyon wall and generally may be regarded as a no-flow boundary. To the east and north of the Naturita site, the San Miguel River dissects the valley alluvium and probably constitutes a hydrologic boundary for the alluvial aquifer based on the depth of channel incisement and 


\begin{tabular}{|c|c|c|c|c|c|}
\hline $\begin{array}{l}\text { SYSTEM } \\
\text { OR SERIES }\end{array}$ & \multicolumn{2}{|c|}{$\begin{array}{l}\text { ROCK } \\
\text { UNIT }\end{array}$} & $\begin{array}{l}\text { MAXIMUM } \\
\text { THICKNESS } \\
\text { (feet/meters) }\end{array}$ & $\begin{array}{l}\text { PREDOMINANT } \\
\text { LITHOLOGY }\end{array}$ & $\begin{array}{c}\text { HYDROGEOLOGIC } \\
\text { UNIT }\end{array}$ \\
\hline Quaternary. & & um & $49 / 15$ & $\begin{array}{l}\text { Silt, sand and gravel } \\
\text { associated with } \\
\text { floodplain and } \\
\text { river terrace }\end{array}$ & $\begin{array}{l}\text { Quaternary } \\
\text { alluvial aquifer }\end{array}$ \\
\hline $\begin{array}{l}\text { Upper } \\
\text { Jurassic }\end{array}$ & $\begin{array}{l}\text { Morrison } \\
\text { Formation }\end{array}$ & $\begin{array}{l}\text { Brushy Basin } \\
\text { Member } \\
\text { Salt Wash } \\
\text { Member }\end{array}$ & $\begin{array}{l}490 / 150 \\
360 / 110\end{array}$ & $\begin{array}{c}\text { Shale, sandstone, } \\
\text { and conglomerate } \\
\text { Sandstone } \\
\text { and shale }\end{array}$ & $\begin{array}{c}\text { Mesozoic } \\
\text { sandstone } \\
\text { aquifer }\end{array}$ \\
\hline
\end{tabular}

MODIFIED FROM ACKERMAN AND RUSH, 1984. 
the seasonal interaction between surface water and ground water. During high river stage periods, the alluvial aquifer is recharged by the river along the eastern boundary of the Naturita site. Conversely, during low river stage periods, water in the alluvial aquifer probably discharges to the river channel. North of the Naturita site the river channel trends northwest, crossing from the east side to the west side of the drainage and bisecting the alluvium down stream of the Naturita site. This configuration creates a natural discharge zone for the alluvial aquifer.

Information obtained from the installation of the monitor wells that fully penetrate the alluvial aquifer indicates that the saturated thickness of the alluvial aquifer varies from about 6 to $10 \mathrm{ft}(2$ to $3 \mathrm{~m})$ in the southern portion of the Naturita site near wells 549 and 546 , to about $14 \mathrm{ft}(4.2 \mathrm{~m})$ north of the former tailings pile area near well 548. In the central portion of the Naturita site, the saturated thickness of the alluvial aquifer is observed to be about $10 \mathrm{ft}(3 \mathrm{~m})$ at alluvial monitor well 506 and $11 \mathrm{ft}(3.3 \mathrm{~m})$ at alluvial monitor well 505 .

Surface water and ground water interaction north of the Naturita site is of interest due to the potential for underflow of ground water beneath the river. The potential for underflow must be assessed to accurately determine potential points of exposure downgradient of the Naturita site. Underflow may occur where a significant portion of the alluvial aquifer is present beneath the river channel. North of the former processing site the vertical extent of river channel incisement in the alluvium is unknown. However it is doubtful that the channel completely bisects the alluvium. The presence of a spring (538) (Figure 2.6) near the river channel indicates that ground water discharges to the river in the area. However it is likely that underflow is also present where the alluvial aquifer is present beneath the river channel.

The measured horizontal hydraulic gradient within the alluvium is 0.005 , based on water level measurements made in alluvial monitor wells 548 and 549 in April 1994. Figure 2.6 is a ground water table elevation map for the Naturita site Figure 2.7 is a hydrogeologic cross-section of the Naturita site.

The average measured hydraulic conductivity value of the alluvial aquifer, as determined from slug tests, is $3.0 \mathrm{ft}$ per day $(0.001 \mathrm{~cm}$ per second) (DOE, 1994b; Calculation number: NAT-06-89-14-02-00). The accuracy of slug test data is affected by a variety of factors (well efficiency, test duration, the radius of influence of the test). Consequently, hydraulic conductivity values, as measured by slug tests, are commonly underestimated by one order of magnitude and can be underestimated by as much as two orders of magnitude. Therefore, the actual hydraulic conductivity of the alluvial aquifer may range from $3.0 \mathrm{ft}$ per day $(0.001 \mathrm{~cm}$ per second) to $300 \mathrm{ft}$ per day $10.1 \mathrm{~cm}$ per second).

Based on the estimated range of hydraulic conductivity, field measured values of hydraulic gradient and an estimated effective porosity of 0.25 , the linear ground water flow velocity likely ranges from $20 \mathrm{ft}(6 \mathrm{~m})$ per year to $200 \mathrm{ft}(60 \mathrm{~m})$ per 


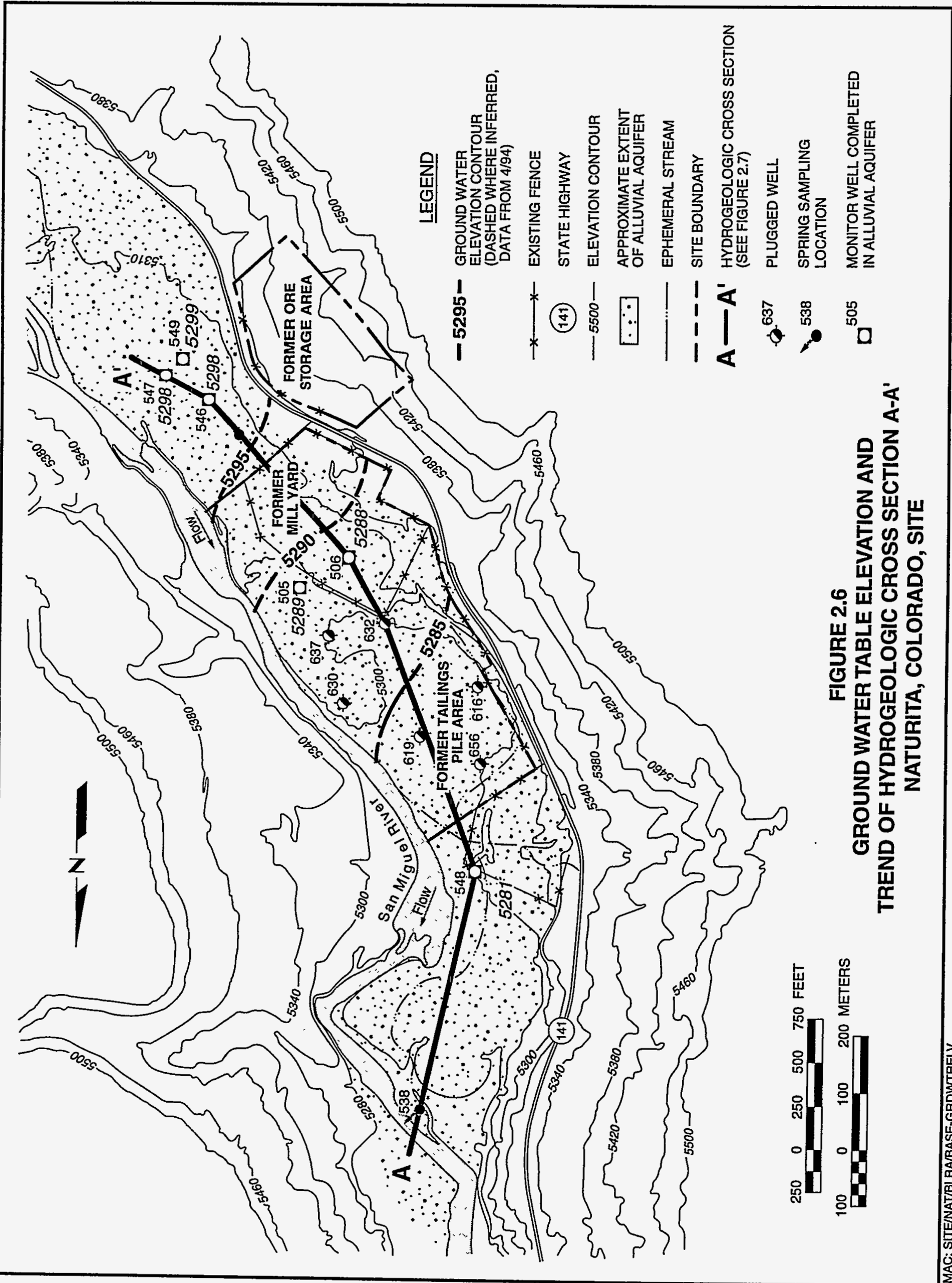




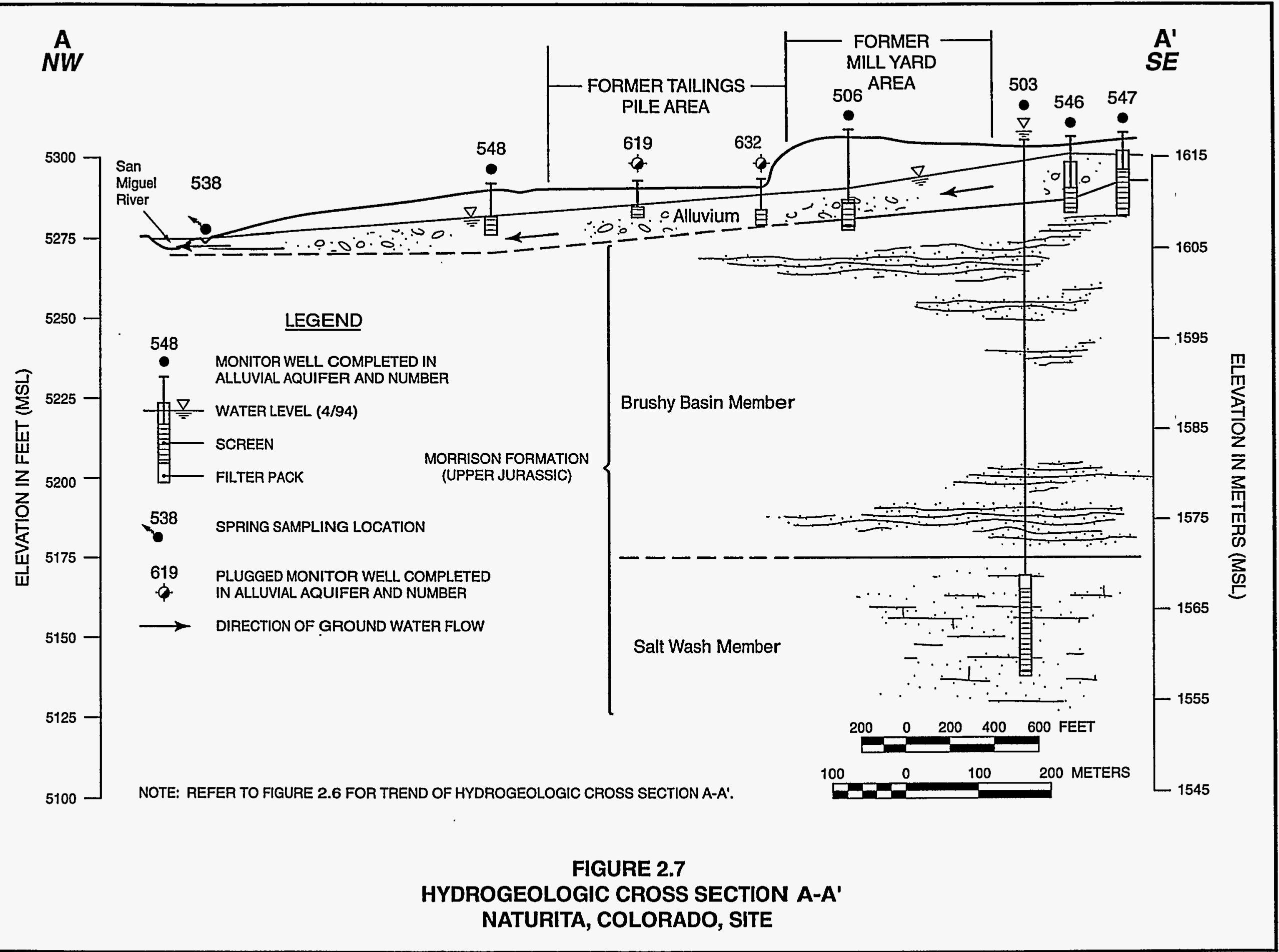


year, and may possibly be as high as $2000 \mathrm{ft}(600 \mathrm{~m})$ per year (DOE, 1994b;

Calculation number: NAT-08-89-14-07-00).

An alternative estimate of ground water flow velocity may be made based on available knowledge of when processing began (1942) and the current distribution of contaminants. Using this approach elevated uranium concentrations measured in the spring (538) during late 199410.11 milligrams per liter [mg/L]), the distance from the sample location (538) and the Naturita site (approximately $3400 \mathrm{ft}$ [1000 m]), and the elapsed time from the onset of processing operations (53 years) indicate that an estimate of the minimum ground water flow velocity is approximately $65 \mathrm{ft}$ per year $(20 \mathrm{~m}$ per year). This value falls within the range of value for average linear ground water flow velocity as estimated from slug test data. Ground water recharge and discharge zones for the alluvial aquifer are generally established relative to the gradient of the San Miguel River. Upstream of the Naturita site, the alluvial aquifer is recharged by inflow from the river. Downstream of the Naturita site, the alluvial aquifer discharges to the river.

\section{Bedrock Aquifer}

While the Brushy Basin and Salt Wash Members are considered collectively to be part of the Mesozoic sandstone aquifer from a regional standpoint, they must be treated separately with respect to the Naturita site due to the distinctly unique hydraulic properties for each unit. The Brushy Basin Member is the uppermost bedrock unit at the Naturita site and consists of interbedded shale, sandstone and conglomerate lenses. The Brushy Basin Member is estimated to range from 110 to $165 \mathrm{ft}(36$ to $50 \mathrm{~m}$ ) thick. Drilling performed in 1985 to install monitor wells at the Naturita site indicated that the Brushy Basin Member is generally not a source of ground water beneath the Naturita site.

Lithologically, the Brushy Basin Member is primarily composed of low permeability shale and mudstone. During the drilling of Salt Wash monitor well 502 (total depth $249 \mathrm{ft}$ [76 m]) the occurrence of ground water was noted at $155 \mathrm{ft}(47 \mathrm{~m})$ below ground surface, within $10 \mathrm{ft}(3 \mathrm{~m})$ of the estimated contact with the lower Salt Wash Member. Subsequent water level measurements for this Salt Wash monitor well consistently note a piezometric head rising to within approximately $50 \mathrm{ft}(20 \mathrm{~m})$ of the land surface. Given the completion interval for this Salt Wash monitor well, 229 to $249 \mathrm{ft}(70$ to $76 \mathrm{~m})$ below ground surface within the Salt Wash Member, it is apparent that the Brushy Basin Member serves to confine ground water present in the Salt Wash Member.

Beneath the Naturita site the Salt Wash Member consists of sandstone with some shale. Two Salt Wash monitor wells, 502 and 503, were completed in the Salt Wash Member. The average hydraulic conductivity for the Salt Wash Member as determined from slug tests is $0.06 \mathrm{ft}$ per day $\left(2 \times 10^{-5} \mathrm{~cm}\right.$ per second) and the horizontal hydraulic gradient is approximately 0.003 , with ground water flow to the northeast preferentially along the bedding of the strata (DOE, 1994b). A preliminary estimate of ground water flow velocity for the bedrock aquifer can be made based on an estimate of the range of hydraulic 
conductivity (using the field measured average as the lower bound and the field measured average plus one or two orders of magnitude as the upper bound), field measured values of hydraulic gradient, and an estimated effective porosity of 0.10 . The resulting likely value for linear ground water flow velocity ranges from $0.7 \mathrm{ft}(0.2 \mathrm{~m})$ per year to $7 \mathrm{ft}(2 \mathrm{~m})$ per year and may be as high as $70 \mathrm{ft}$ $(20 \mathrm{~m})$ per year (DOE, 1994b; Calculation number: NAT-08-89-14-07-00). The vertical gradient between the alluvial aquifer and the Salt Wash Member is 0.04 in an upward direction (DOE, 1994b). The upward vertical hydraulic gradient of ground water in the Salt Wash Member and the thickness and low permeability characteristics of the Brushy Basin Member indicate that the alluvial aquifer may be recharged by upward leakage from the Salt Wash Member. Downward flow from the alluvial aquifer to the Salt Wash Member does not occur due to the upward ground water pressure in the Salt Wash Member.

\subsection{SURFACE WATER}

The Naturita site is located on the west bank of the San Miguel River, which flows in a northwesterly direction through San Miguel Canyon. The San Miguel River originates in the San Juan Mountains near Telluride, Colorado, and joins the Dolores River $20 \mathrm{mi}(30 \mathrm{~km})$ downstream from the town of Naturita. In the vicinity of the Naturita site, the San Miguel River has a drainage area of 1209 square miles $\left(\mathrm{mi}^{2}\right.$ ) (3131 square kilometers $\left[\mathrm{km}^{2}\right.$ ]) (DOE, 1994c).

A U.S. Geological Survey (USGS) gaging station was located on the San Miguel River near the town of Naturita, $3 \mathrm{mi}(5 \mathrm{~km})$ upstream of the Naturita site from 1918 until 1981. During the years 1930 through 1940 data were not recorded for this location. Consequently the period of record for surface water stage and discharge at Naturita encompass 53 years of measurements. in order to assess the distribution of low flow conditions for the San Miguel River at Naturita, a statistical analysis of the available historical data was performed (Calculation number: NAT-05-95-08-00-00). For the low flow analysis, the low normal monthly mean values for discharge for each year were compiled. The results indicate the mean annual monthly low flow value is about 60 cubic feet $\left(\mathrm{ft}^{3}\right)$ per second $\left(1.7 \mathrm{~m}^{3}\right.$ per second) and the fifth percentile value is about $20 \mathrm{ft}^{3}$ per second $\left(0.6 \mathrm{~m}^{3}\right.$ per second). The fifth percentage corresponds to the approximate value of a low flow event having a probability of occurring once every. twenty years.

The former tailings pile and former mill yard areas are located approximately 650 $\mathrm{ft}(200 \mathrm{~m})$ from the San Miguel River and approximately 31 acres (ac) (13.hectares [ha]) of the Naturita site is within the 100-year floodplain of the San Miguel River (DOE, 1994c). Unnamed ephemeral streams drain the uplands to the west and transect the Naturita site north and west of the former tailings 'pile area (see Figure 2.8). An unnamed spring (sampling location 538) (Figure 2.6) is located near the extreme northwest portion of the alluvial aquifer. This spring is a point of discharge for ground water from the alluvial aquifer. 


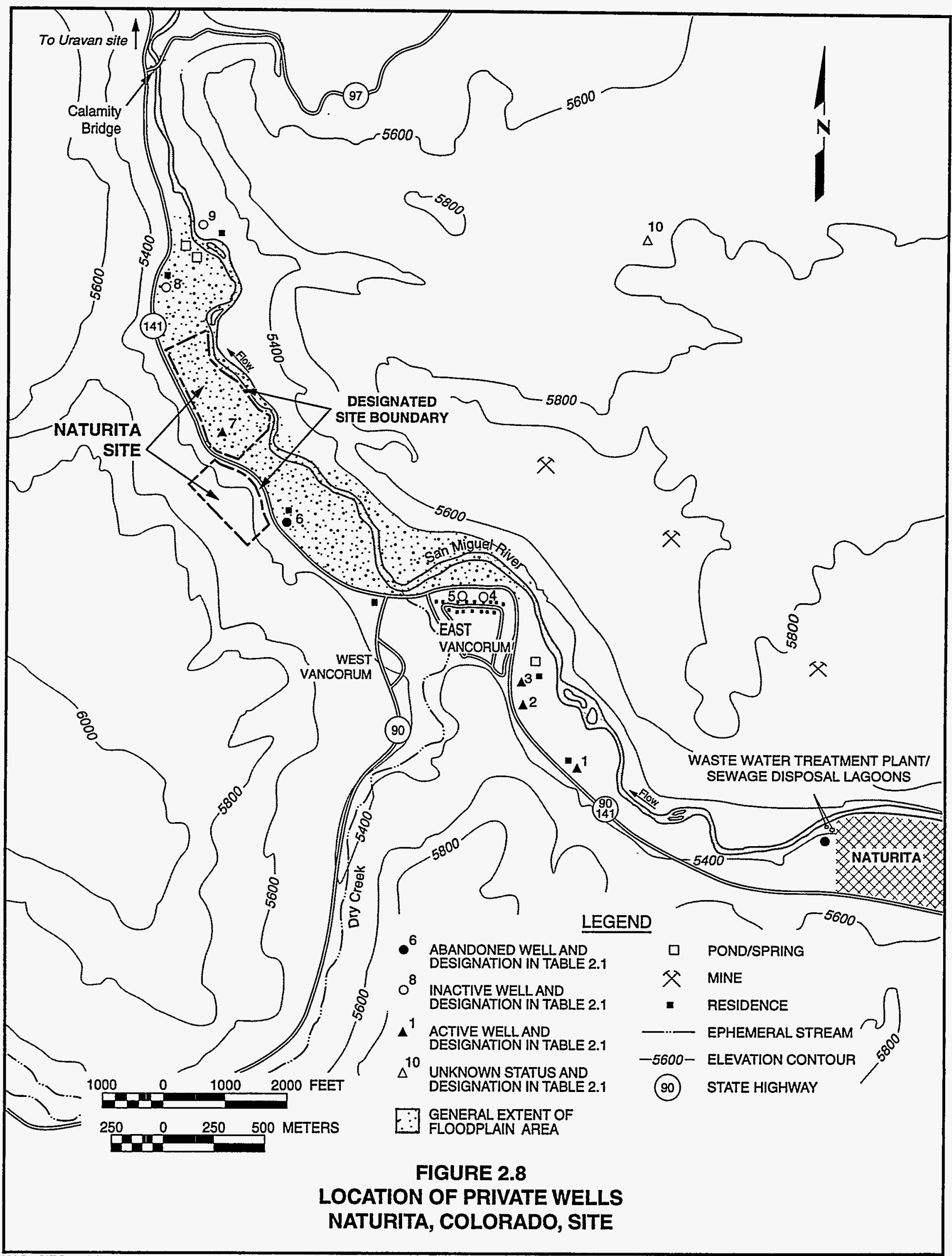


The Naturita site is in Montrose County, Colorado, about $2 \mathrm{mi}(3 \mathrm{~km})$ northwest of the town of Naturita along Colorado State Highway 141 (Figure 2.1). The 53 ac (21 ha) of the former Naturita uranium processing site include the former tailings pile area, the former mill yard and former ore-buying station, and the adjacent former ore storage area (Figure 2.2). The former tailings pile area, which covers about 27 ac (11 ha), is owned by Hecla Mining Corporation (DOE, 1994c). The 14-ac (5.7-ha) former mill yard and former ore-buying station, and the 12-ac (4.9-ha) former ore storage area are owned by Cyprus Foote Mineral Company. The former ore storage area is adjacent to the former tailings pile area and west of Colorado State Highway 141. Approximately 6-ac (2-ha) of the former ore storage area are on lands administered by the Bureau of Land Management (BLM) (DOE, 1995a). The remaining Naturita site area is on Montrose County-administered lands.

According to Montrose County ordinance, the Naturita site is in an agricultural zone (DOE, 1995a) where ranching and farming dominate. Livestock grazing (cattle and horses) is the primary form of agricultural activity in the Naturita site region. Hay and corn are the major crops grown in the region (DOE, 1995a). Tourism is another industry in the Naturita site area. Recreational fishing in the San Miguel River is also popular.

About 480 people live in the town of Naturita and there are about 15 families living in the area extending approximately $5 \mathrm{mi}(8 \mathrm{~km})$ northwest of the town of Naturita and along the highway 141 (DOE, 1995a). Two private properties are northwest of and adjacent to the Naturita site, one on each side of the San Miguel River. The land is used for grazing horses, for growing household vegetables (tomatoes, potatoes, pepper, corn, peas, beans) and fruit (cherry, plum, apricot), and for pasture land. The property located on the western side of the river extends up to about $2 \mathrm{mi}(3 \mathrm{~km})$ downstream and along the river and the highway 141 . There is a hay field on the portion of the property which extends beyond the Calamity Bridge (Figure 2.8).

The private land about $2 \mathrm{mi}(3 \mathrm{~km})$ northwest of the Naturita site is used for cattle grazing; nobody has been living there since 1979 (DOE, 1995a).

The privately owned property located southeast of and adjacent to the Naturita site is currently not occupied; however, it appears to be used for equipment storage.

Two private properties, known as East and West Vancorum, are approximately $1 \mathrm{mi}(1.6 \mathrm{~km})$ southwest of the Naturita site. The East Vancorum residential community consists of 10 currently occupied houses (DOE, 1995a). Plans for West Vancorum include a trailer park development (DOE, 1995a).

Two more private properties are located southeast of the Naturita site between West and East Vancorum and the town of Naturita. Two families live on one of 
them, and the cement plant is on another. A wastewater treatment plant and associated sewage disposal lagoons are at the extreme northeastern corner of the town of Naturita. Wastewater is treated in the lagoon system and then discharged into the San Miguel River about $2 \mathrm{mi}(3 \mathrm{~km})$ southeast of the Naturita site (Figure 2.8).

The town of Naturita and the county are focused on tourism and a new business development in the Naturita site area (DOE, 1995a). To promote tourism and enhance the quality of live of its residents, the town plans to develop the former mill yard and former ore storage areas for recreational purposes. Development plans include a golf course and campground (DOE, 1995a). Also, there are plans to enhance the fishery in the San Miguel River.

The San Miguel River water is currently the only source of water for the town of Naturita water supply system which services the town residents and businesses, as well as most of the residents living within the area extending about $5 \mathrm{mi}(8 \mathrm{~km})$ northwest of the town of Naturita (DOE, 1995a). The water intake from the San Miguel River is about $7 \mathrm{mi}(11 \mathrm{~km})$ southeast and upstream from the town, and $9 \mathrm{mi}(14 \mathrm{~km})$ upstream from the Naturita site.

Consequently, the water would not be affected by the Naturita site activities. A water treatment plant and associated water reservoirs are located immediately near the southern corner of the town. Water treatment consists of sedimentation, filtration, chlorination and fluoridation. Treated water is pumped to a 500,000-gallon (gal) $(2,000,000$-liter [L]) water tank and then to water lines which extend to the town limits. The portion of the water which is untreated goes into a ditch channel for agricultural use.

Naturita residents and businesses are directly connected with the system. Residents living out of the town limits haul the water from the lines located at the Town Hall building. Remaining residents of the area extending about $2 \mathrm{mi}$ $(3 \mathrm{~km})$ northeast of the town have domestic wells or pump the river water (DOE, 1995a).

There is, however, a need for an additional water source (DOE, 1995a). The town of Naturita owns the river water rights for $6.84 \mathrm{ft}^{3}\left(0.194 \mathrm{~m}^{3}\right)$ per second. Of this number, $2.84 \mathrm{ft}^{3}\left(0.08 \mathrm{~m}^{3}\right)$ per second is used for domestic purposes and the remaining water is for agricultural use. This is not considered adequate for the current rate of growth. Thus, the town of Naturita is interested in obtaining the water rights held by the owners of the Naturita site $115 \mathrm{ft}^{3}$ $\left[0.42 \mathrm{~m}^{3}\right]$ per second) (DOE, 1995a). The town of Naturita also owns a private well. However, the details on the status and condition of the well are unknown (DOE, 1995a).

A survey of water use in the area surrounding the Naturita site was conducted using information from the Colorado Division of Water Resources database and field investigations (DOE, 1995a). Table 2.1 summarizes the information 


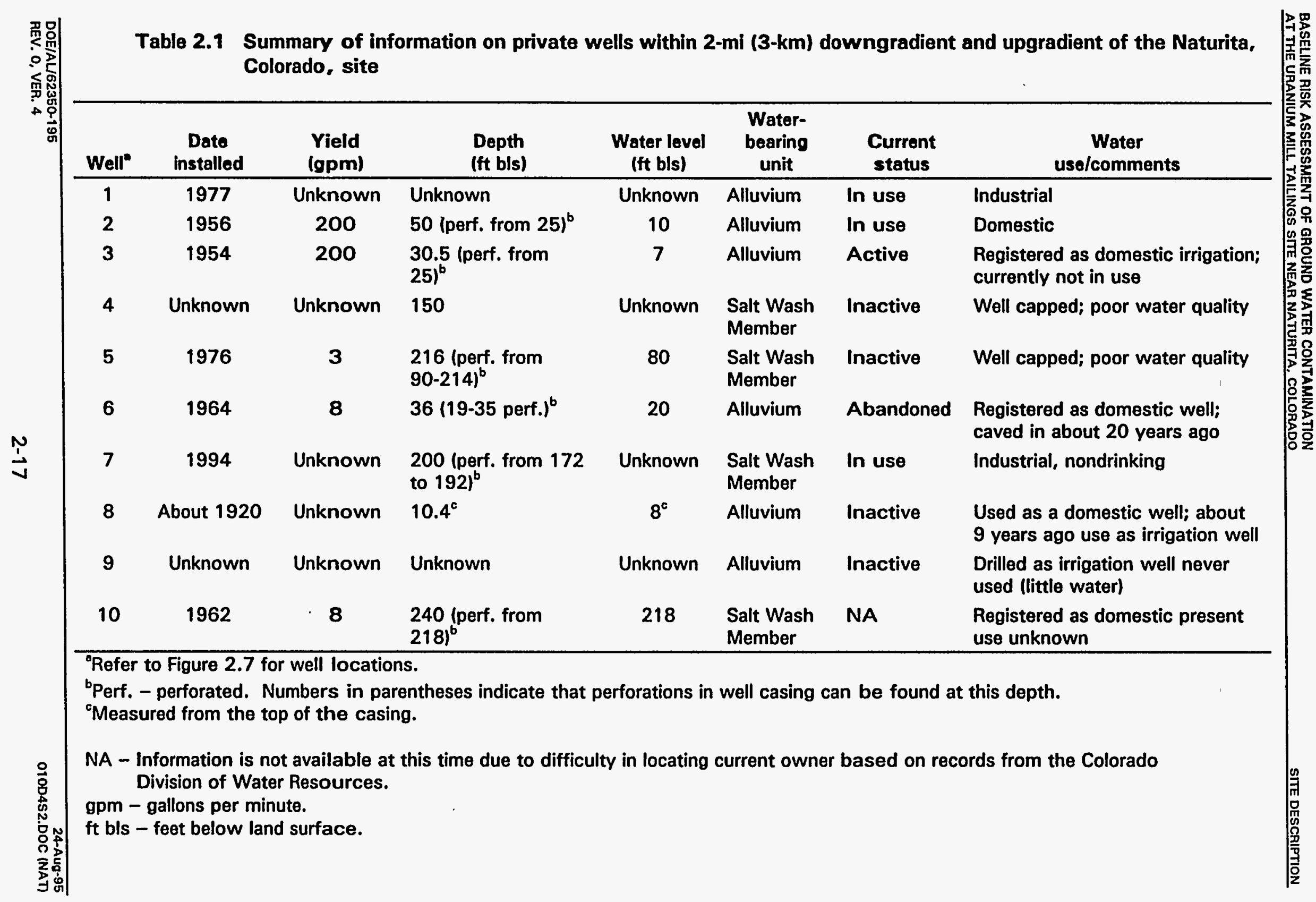


obtained for private wells within about $2 \mathrm{mi}(3-\mathrm{km})$ upgradient and downgradient of the Naturita site. Some of the listed private wells are in use; however, the status of one of the private wells (well number 10 in Figure 2.8) is unknown because of difficulty in determining the current property owner.

The only known downgradient shallow private wells are northeast of and adjacent to the Naturita site on each side of the San Miguel River (wells number 8 and 9 in Figure 2.8). However, these private wells are inactive. Well number 8 was used for drinking and other domestic purposes (DOE, 1995a). About 9 years ago, private well number 8 was used for garden irrigation. An inactive irrigation ditch, known as Blessing Ditch (Figure 2.2) serviced the irrigation needs of the land owners downgradient of the Naturita site (DOE, 1995a). Although drilled for irrigation, private well number 9 (in Figure 2.7) has never been used because of low yield. Both residents haul water from the town of Naturita for domestic purposes. They obtain livestock and irrigation water from the San Miguel River directly (water rights for about $5 \mathrm{ft}^{3}\left[0.1 \mathrm{~m}^{3}\right]$ per second). Residents living on the opposite side of the river obtain irrigation water from the waste water ditch which comes from Nucla. A deep private well (number 7 in Figure 2.7) is located on the Naturita site and is used by the surface remedial action contractor for office purposes with the exception of drinking. This well is completed in the Salt Wash Member of the Morrison Formation. Ground water in this unit is not affected by shallow ground water at the Naturita site because an upward gradient exists from the Salt Wash Member to the alluvium. Also, the alluvial aquifer and Salt Wash Member are separated by the low permeability Brushy Basin Member (see Section 2.4). All other private wells in Figure 2.8 are southeast (hydraulically upgradient) of the Naturita site. 


\subsection{MAGNITUDE AND EXTENT OF CONTAMINATION}

Ground water quality data for the Naturita site collected from 1989 through 1994 are used to characterize the magnitude and extent of site related contamination. This allows for incorporation of 5 years of ground water data representing the most recent information on current site conditions. A statistical summary of background and down gradient ground water quality analyses is presented in Table 3.1 .

Figure 2.5 is a map of the Naturita site showing the DOE monitor well network. A total of 14 DOE monitor wells were sampled. Table 3.2 gives sampling history, screen interval, and hydrogeologic zone of completion for each DOE monitor well. Two DOE monitor wells were completed in the Salt Wash Member of the Morrison Formation of the Mesozoic Sandstone aquifer (Salt Wash Monitor wells) and twelve DOE monitor wells were completed in the alluvial aquifer overlying the Brushy Basin Member of the Morrison Formation (alluvial monitor wells).

As discussed in Section 2.4, the Brushy Basin Member acts as an aquitard between the alluvium and the Salt Wash Member and is not a source of ground water beneath the Naturita site. Due to upward hydraulic gradients from the Salt Wash Member to the alluvium, the alluvial aquifer ground water containing site related contamination cannot migrate downward into the Salt Wash Member. Although ground water quality in Salt Wash monitor wells 502 and 503, is characterized by the presence of arsenic, molybdenum, selenium, uranium, and radium $(-226$ and -228$)$, this is the result of naturally occurring uranium mineralization in the Salt Wash Member beneath the Naturita site (Chenoweth, 1978). Thus, the Salt Wash monitor wells are not further addressed in this risk assessment.

Alluvial monitor wells of the 500 series (Table 3.2) are screened across the contact between the alluvium and the Brushy Basin Member. However, since the Brushy Basin contains very little water, the alluvial contribution dominates ground water in these alluvial monitor wells. The 600 series wells are shallower and completed entirely in the alluvium. The 500 series wells were sampled from 1986 to 1994, while 600 series alluvial monitor wells were sampled from 1989 to 1992.

Most of the water samples collected from alluvial monitor wells at the Naturita site were filtered prior to water quality analysis. One sampling round of unfiltered sample analyses, consisting of a limited list of inorganic constituents was obtained in 1994. The alluvial monitor wells with the highest levels of contamination have no unfiltered water sample data. Therefore, filtered water sample data were used in the statistical evaluation of onsite contamination. A qualitative assessment of paired filtered and unfiltered data suggests that the following constituents are higher in the unfiltered data; iron (average 60 percent higher), manganese (average 7 percent higher), uranium (average 3 percent higher), and vanadium (average 11 percent higher). 
Table 3.1 Comparison of background and on-site ground water quality in the alluvial aquifer, and downgradient spring water quality, Naturita, Colorado, site (July 1989 to April, 1994, filtered water samples)

\begin{tabular}{|c|c|c|c|c|c|}
\hline Constituent & Well ID" & $\begin{array}{c}\text { Frequency of } \\
\text { detection }^{\mathrm{b}}\end{array}$ & Minimum & $\begin{array}{c}\text { Median }^{\circ} \\
\text { (mg/L) }\end{array}$ & Maximum \\
\hline \multicolumn{6}{|c|}{ Chemical (inorganics) } \\
\hline \multicolumn{6}{|l|}{ Aluminum ${ }^{d}$} \\
\hline Background & & $2 / 14$ & $<0.05$ & $<0.09$ & 0.13 \\
\hline On-site & & $6 / 13$ & $<0.05$ & $<0.10$ & 0.28 \\
\hline Spring ${ }^{\circ}$ & 538 & $0 / 0$ & NA & NA & NA \\
\hline \multicolumn{6}{|l|}{ Ammonium $^{f, d}$} \\
\hline Background & & $4 / 12$ & 0.09 & $<0.10$ & 0.14 \\
\hline On-site & & $7 / 11$ & $<0.10$ & 0.26 & 1.4 \\
\hline Spring & 538 & $0 / 0$ & NA & NA & NA \\
\hline \multicolumn{6}{|l|}{ Antimony ${ }^{d}$} \\
\hline Background & & $0 / 15$ & $<0.003$ & $<0.003$ & $<0.020$ \\
\hline On-site & & $5 / 13$ & $<0.003$ & $<0.003$ & 0.043 \\
\hline Spring & 538 & $0 / 1$ & NA & $<0.003$ & NA \\
\hline \multicolumn{6}{|l|}{ Arsenic $^{d}$} \\
\hline Background & & $0 / 15$ & $<0.001$ & $<0.01$ & $<0.01$ \\
\hline On-site & & $11 / 13$ & 0.007 & 0.03 & 0.08 \\
\hline Spring & 538 & $0 / 1$ & NA & $<0.005$ & NA \\
\hline \multicolumn{6}{|l|}{ Barium ${ }^{d}$} \\
\hline Background & & $6 / 14$ & 0.02 & $<0.1$ & $<0.1$ \\
\hline On-site & & $7 / 13$ & 0.04 & $<0.1$ & $<0.2$ \\
\hline Spring & 538 & $0 / 0$ & NA & NA & NA \\
\hline \multicolumn{6}{|l|}{ Beryllium } \\
\hline Background & & $0 / 10$ & $<0.005$ & $<0.005$ & $<0.01$ \\
\hline On-site & & $0 / 9$ & $<0.005$ & $<0.005$ & $<0.01$ \\
\hline Spring & 538 & $0 / 0$ & NA & NA & NA \\
\hline \multicolumn{6}{|l|}{ Boron $^{d}$} \\
\hline Background & & $0 / 4$ & $<0.1$ & $<0.1$ & $<0.1$ \\
\hline On-site & & $4 / 4$ & 0.2 & 0.2 & 0.3 \\
\hline Spring & 538 & $0 / 0$ & NA & NA & NA \\
\hline \multicolumn{6}{|l|}{ Bromide } \\
\hline Background & & $0 / 5$ & $<0.1$ & $<0.1$ & $<2.0$ \\
\hline On-site & & $3 / 4$ & $<0.1$ & 0.4 & 0.6 \\
\hline Spring & 538 & $0 / 1$ & $N A$ & $<0.10$ & NA \\
\hline
\end{tabular}


Table 3.1 Comparison of background and on-site ground water quality in the alluvial aquifer, and downgradient spring water quality, Naturita, Colorado, site (July 1989 to April, 1994, filtered water samples) (Continued)

\begin{tabular}{|c|c|c|c|c|c|}
\hline & Well ID & $\begin{array}{c}\text { Frequency of } \\
\text { detection }\end{array}$ & Minimum & $\frac{\text { Median }^{\circ}}{\text { (mg/L) }}$ & Maximum \\
\hline Cadmium & & & \multicolumn{3}{|c|}{$(\mathrm{mg} / \mathrm{L})$} \\
\hline $\begin{array}{l}\text { Background } \\
\text { On-site } \\
\text { Spring }\end{array}$ & 538 & $\begin{array}{c}1 / 14 \\
3 / 13 \\
0 / 0\end{array}$ & $\begin{array}{l}<0.001 \\
<0.001 \\
\text { NA }\end{array}$ & $\begin{array}{l}<0.001 \\
<0.001 \\
\text { NA }\end{array}$ & $\begin{array}{r}0.001 \\
0.002 \\
\text { NA }\end{array}$ \\
\hline Calcium $^{d}$ & & & & & \\
\hline $\begin{array}{l}\text { Background } \\
\text { On-site } \\
\text { Spring }\end{array}$ & $\begin{array}{l}632 \\
538\end{array}$ & $\begin{array}{l}15 / 15 \\
7 / 7 \\
1 / 1\end{array}$ & $\begin{array}{r}98 \\
210 \\
\text { NA }\end{array}$ & $\begin{array}{l}155 \\
243 \\
170\end{array}$ & $\begin{array}{r}251 \\
281 \\
\text { NA }\end{array}$ \\
\hline $\begin{array}{l}\text { Chloride }^{d} \\
\text { Background } \\
\text { On-site } \\
\text { Spring }\end{array}$ & $\begin{array}{l}616 \\
538\end{array}$ & $\begin{array}{l}15 / 15 \\
6 / 6 \\
1 / 1\end{array}$ & $\begin{array}{l}2.2 \\
419 \\
\text { NA }\end{array}$ & $\begin{array}{c}8.2 \\
546 \\
7.4\end{array}$ & $\begin{array}{r}16 \\
856 \\
N A\end{array}$ \\
\hline $\begin{array}{l}\text { Chromium } \\
\text { Background } \\
\text { On-site } \\
\text { Spring }\end{array}$ & 538 & $\begin{array}{c}0 / 12 \\
0 / 11 \\
0 / 0\end{array}$ & $\begin{array}{l}<0.01 \\
<0.01 \\
N A\end{array}$ & $\begin{array}{l}<0.01 \\
<0.01 \\
\text { NA }\end{array}$ & $\begin{array}{l}<0.01 \\
<0.01 \\
\text { NA }\end{array}$ \\
\hline $\begin{array}{l}\text { Cobalt } \\
\text { Background } \\
\text { On-site } \\
\text { Spring }\end{array}$ & 538 & $\begin{array}{l}0 / 4 \\
0 / 4 \\
0 / 0\end{array}$ & $\begin{array}{l}<0.05 \\
<0.05 \\
\text { NA }\end{array}$ & $\begin{array}{l}<0.05 \\
<0.05 \\
N A\end{array}$ & $\begin{array}{l}<0.05 \\
<0.05 \\
\text { NA }\end{array}$ \\
\hline $\begin{array}{l}\text { Copper } \\
\text { Background } \\
\text { On-site } \\
\text { Spring }\end{array}$ & 538 & $\begin{array}{l}0 / 10 \\
0 / 9 \\
0 / 0\end{array}$ & $\begin{array}{l}<0.01 \\
<0.01 \\
\text { NA }\end{array}$ & $\begin{array}{l}<0.02 \\
<0.02 \\
N A\end{array}$ & $\begin{array}{l}<0.02 \\
<0.02 \\
\text { NA }\end{array}$ \\
\hline $\begin{array}{l}\text { Cyanide } \\
\text { Background } \\
\text { On-site } \\
\text { Spring }\end{array}$ & 538 & $\begin{array}{c}0 / 14 \\
0 / 13 \\
0 / 0\end{array}$ & $\begin{array}{l}<0.01 \\
<0.01 \\
\text { NA }\end{array}$ & $\begin{array}{l}<0.01 \\
<0.01 \\
N A\end{array}$ & $\begin{array}{l}<0.02 \\
<0.02 \\
N A\end{array}$ \\
\hline $\begin{array}{l}\text { Fluoride }^{d} \\
\text { Background } \\
\text { On-site } \\
\text { Spring } \\
\end{array}$ & $\begin{array}{l}616 \\
538 \\
\end{array}$ & $\begin{array}{c}15 / 15 \\
6 / 6 \\
1 / 1 \\
\end{array}$ & $\begin{array}{l}0.30 \\
1.0 \\
\text { NA }\end{array}$ & $\begin{array}{l}0.30 \\
1.4 \\
0.20 \\
\end{array}$ & $\begin{array}{c}0.57 \\
1.6 \\
\text { NA } \\
\end{array}$ \\
\hline
\end{tabular}


Table 3.1 Comparison of background and on-site ground water quality in the alluvial aquifer, and downgradient spring water quality, Naturita, Colorado, site (July 1989 to April, 1994, filtered water samples) (Continued)

\begin{tabular}{|c|c|c|c|c|c|}
\hline Constituent & Well ID & $\begin{array}{c}\text { Frequency of } \\
\text { detection }^{b}\end{array}$ & Minimum & \multirow[t]{2}{*}{$\begin{array}{c}\text { Median }^{\circ} \\
\text { (mg/L) }\end{array}$} & Maximum \\
\hline Iron & & & & & \\
\hline $\begin{array}{l}\text { Background } \\
\text { On-site } \\
\text { Spring }\end{array}$ & 538 & $\begin{array}{l}2 / 5 \\
2 / 4 \\
1 / 1\end{array}$ & $\begin{array}{l}<0.03 \\
<0.03 \\
N A\end{array}$ & $\begin{array}{r}<0.03 \\
<0.05 \\
0.27\end{array}$ & $\begin{array}{l}0.08 \\
0.09 \\
\text { NA }\end{array}$ \\
\hline $\begin{array}{l}\text { Lead } \\
\text { Background } \\
\text { On-site } \\
\text { Spring }\end{array}$ & 538 & $\begin{array}{l}0 / 10 \\
0 / 9 \\
0 / 0\end{array}$ & $\begin{array}{l}<0.005 \\
<0.005 \\
\text { NA }\end{array}$ & $\begin{array}{l}<0.01 \\
<0.01 \\
\text { NA }\end{array}$ & $\begin{array}{l}<0.01 \\
<0.01 \\
\text { NA }\end{array}$ \\
\hline $\begin{array}{l}\text { Magnesium }^{d} \\
\text { Background } \\
\text { On-site } \\
\text { Spring }\end{array}$ & $\begin{array}{l}632 \\
538\end{array}$ & $\begin{array}{l}15 / 15 \\
7 / 7 \\
1 / 1\end{array}$ & $\begin{array}{l}24 \\
70 \\
\text { NA }\end{array}$ & $\begin{array}{l}32 \\
89 \\
39\end{array}$ & $\begin{array}{r}49 \\
97 \\
\text { NA }\end{array}$ \\
\hline $\begin{array}{l}\text { Manganese }^{d} \\
\text { Background } \\
\text { On-site } \\
\text { Spring }\end{array}$ & $\begin{array}{l}656 \\
538\end{array}$ & $\begin{array}{l}6 / 15 \\
6 / 6 \\
1 / 1\end{array}$ & $\begin{array}{c}<0.01 \\
1.9 \\
\text { NA }\end{array}$ & $\begin{array}{c}<0.01 \\
5.1 \\
0.98\end{array}$ & $\begin{array}{l}0.05 \\
7.5 \\
\text { NA }\end{array}$ \\
\hline $\begin{array}{l}\text { Mercury } \\
\text { Background } \\
\text { On-site } \\
\text { Spring }\end{array}$ & 538 & $\begin{array}{l}0 / 10 \\
0 / 9 \\
0 / 0\end{array}$ & $\begin{array}{l}<0.0002 \\
<0.0002 \\
N A\end{array}$ & $\begin{array}{l}<0.0002 \\
<0.0002 \\
\text { NA }\end{array}$ & $\begin{array}{l}<0.0002 \\
<0.0002 \\
\text { NA }\end{array}$ \\
\hline $\begin{array}{l}\text { Molybdenum } \\
\text { Background } \\
\text { On-site } \\
\text { Spring }\end{array}$ & $\begin{array}{l}616 \\
538\end{array}$ & $\begin{array}{c}3 / 15 \\
6 / 6 \\
1 / 1\end{array}$ & $\begin{array}{c}<0.01 \\
0.25 \\
\text { NA }\end{array}$ & $\begin{array}{r}<0.01 \\
0.29 \\
0.01\end{array}$ & $\begin{array}{l}0.03 \\
0.38 \\
\text { NA }\end{array}$ \\
\hline $\begin{array}{l}\text { Nickel } \\
\text { Background } \\
\text { On-site } \\
\text { Spring }\end{array}$ & 538 & $\begin{array}{l}0 / 10 \\
0 / 9 \\
0.0\end{array}$ & $\begin{array}{l}<0.04 \\
<0.04 \\
\text { NA }\end{array}$ & $\begin{array}{l}<0.04 \\
<0.04 \\
\text { NA }\end{array}$ & $\begin{array}{l}<0.04 \\
<0.04 \\
\text { NA }\end{array}$ \\
\hline $\begin{array}{l}\text { Nitrate }^{d} \\
\text { Background } \\
\text { On-site } \\
\text { Spring }\end{array}$ & 538 & $\begin{array}{c}8 / 14 \\
10 / 13 \\
1 / 1 \\
\end{array}$ & $\begin{array}{l}<0.01 \\
<0.1 \\
\text { NA }\end{array}$ & $\begin{array}{l}1.7 \\
2.7 \\
3.8\end{array}$ & $\begin{array}{r}13 \\
45 \\
\text { NA }\end{array}$ \\
\hline
\end{tabular}


Table 3.1 Comparison of background and on-site ground water quality in the alluvial aquifer, and downgradient spring water quality, Naturita, Colorado, site (July 1989 to April, 1994, filtered water samples) (Continued)

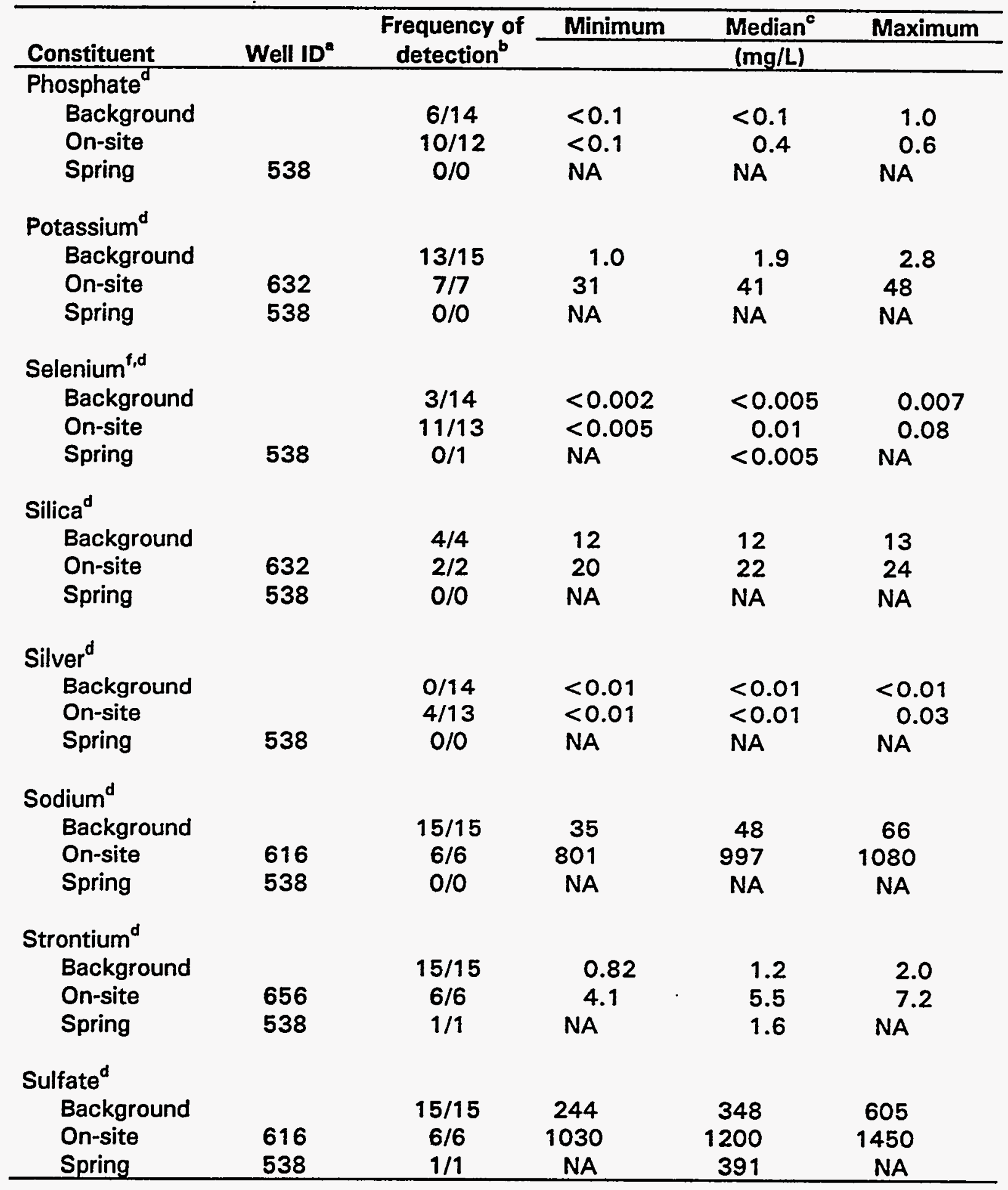


Table 3.1 Comparison of background and on-site ground water quality in the alluvial aquifer, and downgradient spring water quality, Naturita, Colorado, site (July 1989 to April, 1994, filtered water samples) (Continued)

\begin{tabular}{|c|c|c|c|c|c|}
\hline Constituent & Well ID & $\begin{array}{c}\text { Frequency of } \\
\text { detection }^{\text {b }}\end{array}$ & \multicolumn{3}{|c|}{$(\mathrm{mg} / \mathrm{L})$} \\
\hline Sulfide & & & & & \\
\hline $\begin{array}{l}\text { Background } \\
\text { On-site } \\
\text { Spring }\end{array}$ & 538 & $\begin{array}{c}3 / 14 \\
3 / 13 \\
0 / 0\end{array}$ & $\begin{array}{l}<0.1 \\
<0.1 \\
N A\end{array}$ & $\begin{array}{l}<0.1 \\
<0.1 \\
\text { NA }\end{array}$ & $\begin{array}{l}2.3 \\
2.3 \\
\text { NA }\end{array}$ \\
\hline \multicolumn{6}{|l|}{ Thallium } \\
\hline $\begin{array}{l}\text { Background } \\
\text { On-site } \\
\text { Spring }\end{array}$ & 538 & $\begin{array}{l}0 / 10 \\
0 / 9 \\
0 / 0\end{array}$ & $\begin{array}{l}<0.01 \\
<0.01 \\
N A\end{array}$ & $\begin{array}{l}<0.01 \\
<0.01 \\
N A\end{array}$ & $\begin{array}{l}<0.1 \\
<0.1 \\
\text { NA }\end{array}$ \\
\hline \multicolumn{6}{|l|}{ Tin } \\
\hline $\begin{array}{l}\text { Background } \\
\text { On-site } \\
\text { Snrinn }\end{array}$ & & $\begin{array}{l}0 / 14 \\
2 / 11 \\
0 / 0\end{array}$ & $\begin{array}{l}<0.005 \\
<0.005\end{array}$ & $\begin{array}{l}<0.005 \\
<0.01\end{array}$ & $\begin{array}{r}<0.01 \\
0.13\end{array}$ \\
\hline Spring & 538 & $0 / 0$ & NA & & \\
\hline \multicolumn{6}{|l|}{ Uranium $^{d}$} \\
\hline $\begin{array}{l}\text { Background } \\
\text { On-site }\end{array}$ & & $\begin{array}{l}15 / 15 \\
13 / 13\end{array}$ & $\begin{array}{l}0.002 \\
1.0\end{array}$ & $\begin{array}{l}0.012 \\
2.2\end{array}$ & $\begin{array}{l}0.025 \\
5.2\end{array}$ \\
\hline Spring & 538 & $1 / 1$ & NA & 0.11 & NA \\
\hline \multicolumn{6}{|l|}{ Vanadium ${ }^{d}$} \\
\hline $\begin{array}{l}\text { Background } \\
\text { On-site } \\
\text { Spring }\end{array}$ & $\begin{array}{l}616 \\
538\end{array}$ & $\begin{array}{c}6 / 15 \\
6 / 6 \\
0 / 1\end{array}$ & $\begin{array}{c}<0.01 \\
1.5 \\
\text { NA }\end{array}$ & $\begin{array}{c}<0.01 \\
6.4 \\
<0.01\end{array}$ & $\begin{array}{l}0.02 \\
10 \\
\text { NA }\end{array}$ \\
\hline \multicolumn{6}{|l|}{ Zinc } \\
\hline $\begin{array}{l}\text { Background } \\
\text { On-site } \\
\text { Spring }\end{array}$ & 538 & $\begin{array}{c}15 / 15 \\
5 / 13 \\
0 / 1 \\
\end{array}$ & $\begin{array}{l}0.018 \\
<0.005 \\
\text { NA }\end{array}$ & $\begin{aligned} & 0.057 \\
&< 0.005 \\
&< 0.05 \\
&\end{aligned}$ & $\begin{array}{l}0.08 \\
0.11 \\
\text { NA. }\end{array}$ \\
\hline
\end{tabular}


Table 3.1 Comparison of background and on-site ground water quality in the alluvial aquifer, and downgradient spring water quality, Naturita, Colorado, site (July 1989 to April, 1994, filtered water samples) (Concluded)

\begin{tabular}{|c|c|c|c|c|c|}
\hline Constituent & Well ID' & $\begin{array}{c}\text { Number of } \\
\text { samples }^{b}\end{array}$ & Minimum & $\frac{\text { Median }^{c}}{\text { (pCi/L) }}$ & Maximum \\
\hline \multicolumn{6}{|l|}{$\begin{array}{l}\text { Radionuclides } \\
\text { Lead-210 }\end{array}$} \\
\hline $\begin{array}{l}\text { Background } \\
\text { On-site } \\
\text { Spring }\end{array}$ & 538 & $\begin{array}{l}4 \\
4 \\
0\end{array}$ & $\begin{array}{l}0.0 \\
3.4 \\
\text { NA }\end{array}$ & $\begin{array}{l}0.3 \\
5.2 \\
\text { NA }\end{array}$ & $\begin{array}{l}0.6 \\
13.5 \\
\text { NA }\end{array}$ \\
\hline \multicolumn{6}{|l|}{ Polonium-210 } \\
\hline $\begin{array}{l}\text { Background } \\
\text { On-site } \\
\text { Spring }\end{array}$ & 538 & $\begin{array}{l}4 \\
4 \\
0\end{array}$ & $\begin{array}{l}0.0 \\
0.5 \\
\text { NA }\end{array}$ & $\begin{array}{l}0.1 \\
0.9 \\
\text { NA }\end{array}$ & $\begin{array}{r}0.2 \\
4.5 \\
N A\end{array}$ \\
\hline
\end{tabular}

Radium-226

Background

On-site

Spring

538

$\begin{array}{crrr}15 & 0.0 & 0.1 & 0.6 \\ 13 & 3.2 & 4.9 & 28.6 \\ 0 & \text { NA } & \text { NA } & \text { NA }\end{array}$

Radium-228 ${ }^{d}$

Background

On-site

Spring

538

15

13

0

40.0

0.0

NA
0.0

0.0

NA
0

0.1

0.2

6.7

1.1

3.4

NA

NA

Thorium-230

Background

Spring

538

0.6

0.3

NA

0.9

${ }^{8}$ Background data are from 547 and 549; on-site data are from combined

monitor wells 616 and 632 , unless otherwise specified.

${ }^{b}$ Frequency of detection = number of samples reported at or above the detection limit/total number of samples.

Median = the 50th percentile of the data.

${ }^{d}$ Constituent is above background.

'The spring was sampled only one time in November 1994.

'Certain nondetect data associated with matrix interferences were omitted.

NA - not available. 
Table 3.2 DOE monitor well information, Naturita, Colorado, site

\begin{tabular}{|c|c|c|c|c|}
\hline Well ID & Location & Years sampled & $\begin{array}{l}\text { Number } \\
\text { of rounds }\end{array}$ & $\begin{array}{c}\text { Screen } \\
\text { interval } \\
\text { (ft) }\end{array}$ \\
\hline \multicolumn{5}{|c|}{ Alluvial monitor wells } \\
\hline \multicolumn{5}{|c|}{ Background Wells } \\
\hline 547 & $\begin{array}{l}\text { Southeast of former mill } \\
\text { yard }\end{array}$ & $\begin{array}{l}1986-1987,1989- \\
1992,1994\end{array}$ & 11 & $10.0-20.0$ \\
\hline 549 & & $1987,1989-1992$ & 9 & $11.5-16.5$ \\
\hline \multicolumn{5}{|c|}{ On-site wells } \\
\hline 505 & Former mill yard & $\begin{array}{l}1986-1987,1989- \\
1992,1994\end{array}$ & 12 & $16.0-21.0$ \\
\hline 506 & Former tailings pile area & $\begin{array}{l}1986-1987,1989- \\
1992,1994\end{array}$ & 12 & $22.5-27.5$ \\
\hline 616 & Former tailings pile area & $1989-1992$ & 6 & $7.5-10.0$ \\
\hline 619 & Former tailings pile area & 1989-1992 & 7 & $7.5-10.0$ \\
\hline 630 & Former tailings pile area & $1989-1992$ & 7 & $7.5-10.0$ \\
\hline 632 & Former tailings pile area & 1989-1992 & 7 & $7.5-10.0$ \\
\hline 637 & Former tailings pile area & $1989-1992$ & 7 & $5.5-8.0$ \\
\hline 656 & Former tailings pile area & $1990-1992$ & 4 & $7.5-10.0$ \\
\hline \multicolumn{5}{|l|}{ Upgradient } \\
\hline 546 & $\begin{array}{l}\text { Southeast of former mill } \\
\text { yard }\end{array}$ & $\begin{array}{l}1986-1987,1989- \\
1992\end{array}$ & 10 & $10.0-15.0$ \\
\hline \multicolumn{5}{|c|}{ Downgradient } \\
\hline 548 & $\begin{array}{l}\text { Northwest of former } \\
\text { tailings pile area }\end{array}$ & $\begin{array}{l}1986-1987,1989- \\
1992,1994\end{array}$ & 11 & $16.0-21.0$ \\
\hline \multicolumn{5}{|c|}{ Salt Wash monitor wells } \\
\hline 502 & Former mill yard & $\begin{array}{l}1986-1987,1989- \\
1992,1994\end{array}$ & 11 & $\begin{array}{l}229.25 \\
249.25\end{array}$ \\
\hline 503 & $\begin{array}{l}\text { Southeast of former mill } \\
\text { yard }\end{array}$ & $\begin{array}{l}1986-1987,1989- \\
1992,1994\end{array}$ & 10 & $140.0-165.0$ \\
\hline
\end{tabular}




\subsection{BACKGROUND WATER QUALITY SUMMARY}

Background water quality is defined as the quality of ground water that would be present at the Naturita site if uranium milling activities had not taken place. Upgradient alluvial monitor wells 547 and 549 (Figure 2.5) are located in an area containing a minor amount of wind-blown site related contamination on the land surface. These alluvial monitor wells have had maximum uranium concentrations in groundwater of $0.025 \mathrm{mg} / \mathrm{L}$ and a maximum measured activity of radium-226 plus radium-228 of 6.8 picocuries per liter $(\mathrm{pCi} / \mathrm{L})$.

These values are within the range of natural background values measured for other UMTRA sites having a similar hydrologic setting (DOE, 1995b). Uranium and radium in these wells could come from natural sources. The Sait Wash Member beneath the Naturita site is a known uranium ore body, and the Brushy Basin Member, lying directly beneath the alluvium, is known to contain uranium ore in nearby regions (Brod and Stone, 1981). Nevertheless, alluvial monitor wells 547 and 549 will be treated as an upper bound on background rather than natural background in this risk assessment. Thus, natural background water may hàve lower levels of some constituents than are observed in monitor wells 547 and 549.

Ground water in alluvial monitor wells 547 and 549 is classified as a calcium sulfate type (Figure 3.1) and the $\mathrm{pH}$ ranges from 6.84 to 7.32. Total dissolved solids range from 568 to $2520 \mathrm{mg} / \mathrm{L}$ and the alkalinity (as $\mathrm{mg} / \mathrm{L} \mathrm{CaCO}_{3}$ ) ranges from 211 to 268. Most trace elements were detected at low concentrations or were never detected in analyses of ground water in these wells. However, in addition to uranium and radium, other trace elements that were historically present are fluoride (up to $0.57 \mathrm{mg} / \mathrm{L}$ ), strontium (up to $1.96 \mathrm{mg} / \mathrm{L}$ ), and sulfide (up to $2.3 \mathrm{mg} / \mathrm{L}$ ). Phosphate has been as high as $1.0 \mathrm{mg} / \mathrm{L}$ and nitrate values as high as $12.5 \mathrm{mg} / \mathrm{L}$ (as $\mathrm{NO}_{3}$ ) have been observed. Phosphate and nitrate values may be related to agricultural activities in the area.

\subsection{MAGNITUDE OF SITE-RELATED CONTAMINATION}

As discussed in Section 2.1, salt roasting and alkaline leaching, followed by acid leaching of uranium/vanadium ores contributed sodium chloride $(\mathrm{NaCl})$, sodium bicarbonate $\left(\mathrm{NaHCO}_{3}\right)$, sulfuric acid $\left(\mathrm{H}_{2} \mathrm{SO}_{4}\right)$ and ammonium sulfate $\left[\left(\mathrm{NH}_{4}\right)_{2} \mathrm{SO}_{4}\right]$ to the former tailings pile, and, thus, to the ground water at the Naturita site. Therefore, indicators of contamination expected in down gradient wells are the sodium $\left(\mathrm{Na}^{+}\right)$, bicarbonate $\left(\mathrm{HCO}_{3}{ }^{-}\right)$, sulfate $\left(\mathrm{SO}_{4}{ }^{2-}\right)$, chloride $(\mathrm{Cl})$, and ammonium $\left(\mathrm{NH}_{4}{ }^{+}\right)$ions. Contaminants that can be expected in association with the uranium/vanadium ores themselves include arsenic (As), molybdenum (Mo), selenium (Se), uranium (U), and vanadium (V) (Evans, 1987).

Sources of ground water site-related contamination at the Naturita site include ore, original processing fluids, and tailings. The former tailings pile was removed from the Naturita site in the late 1970's, thus, removing a major source of ground water site-related contamination. The primary sources of site-related 


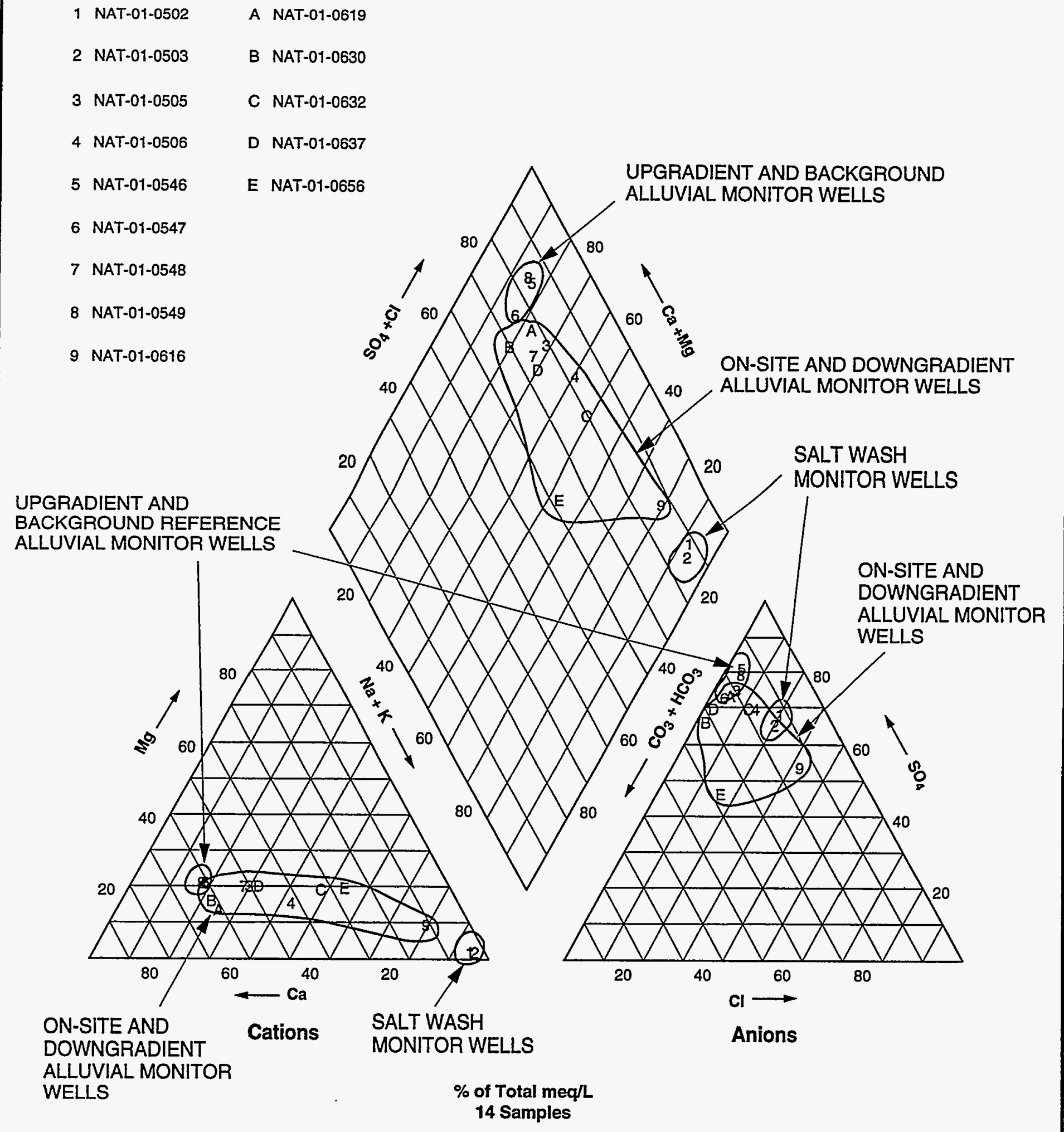

DATA FROM 6/92.

FIGURE 3.1

MAJOR ELEMENT CLASSIFICATION OF GROUND WATER FROM DOE ALLUVIAL AND SALT WASH MONITOR WELLS NATURITA, COLORADO, SITE 
contamination remaining include sub-tailings soil and contaminated soil in the former mill yard. The latter contains tailings used as fill material on the lower former mill terrace (DOE, 1995a). The sub-tailings soil contains contaminants that were leached out of the tailings by acidic pore fluids and were subsequently precipitated or adsorbed when acidic solutions were neutralized by naturally occurring carbonate minerals in soils beneath the pile.

Chloride is a primary indicator of processing chemicals at the Naturita site and it is largely unaffected by precipitation and adsorption reactions. A chloride isopleth map (Figure 3.2) shows that remaining high chloride concentrations are confined to an elongate area in the alluvium underlying the western half of the former tailings pile area. Ground water underlying the eastern half of the former tailings pile area, closest to the river, has chloride concentrations at or below those found in background wells. This distribution is the result of former alkaline leach tailings that were deposited on the western half of the Naturita site (DOE, 1995a).

In contrast, uranium concentrations that exceed background are distributed over a much larger area (Figure 3.3). This distribution is the result of multiple sources of uranium. Alkaline leach tails had a higher concentration of uranium than acid leach tails formerly deposited on the eastern half of the Naturita site. This source of contamination has been removed. However, tailings used as fill material are still present in the lower terrace of the former mill yard (DOE, $1995 \mathrm{a})$ and are likely contributing uranium to the ground water on the eastern half of the Naturita site.

At the Naturita site, the alluvium is laterally truncated to the west by an escarpment of Morrison Formation (Figures 3.2 and 3.3). Therefore, site-related contamination and ground water flow in the alluvium is effectively limited to the area between the escarpment of the Morrison Formation west of the Naturita site and the San Miguel River east of the Naturita site with ground water flowing north, parallel to the river. Site-related contamination is elongated to the north from the Naturita site, in the direction of ground water flow (Figures 3.2 and 3.3).

There is limited information regarding the down gradient extent of contamination. Uranium contamination clearly exists in monitor well 548, the farthest down gradient well at the Naturita site. A'spring that was first sampled in November 1994 has a uranium concentration of $0.11 \mathrm{mg} / \mathrm{L}$. While technically a surface water sampling location, a spring represents ground water that has just emerged at the surface. This spring is a discharge point for alluvial aquifer (Figure 3.3). This information indicates that some uranium from the Naturita site has traveled approximately $0.4 \mathrm{mi}(.6 \mathrm{~km})$ down gradient of the former tailings pile area.

An estimate of the vertical extent of uranium contamination is given in a hydrogeologic cross section that extends from background well 547 to the San Miguel River near spring location 538 (Figure 3.4). The distribution of uranium 


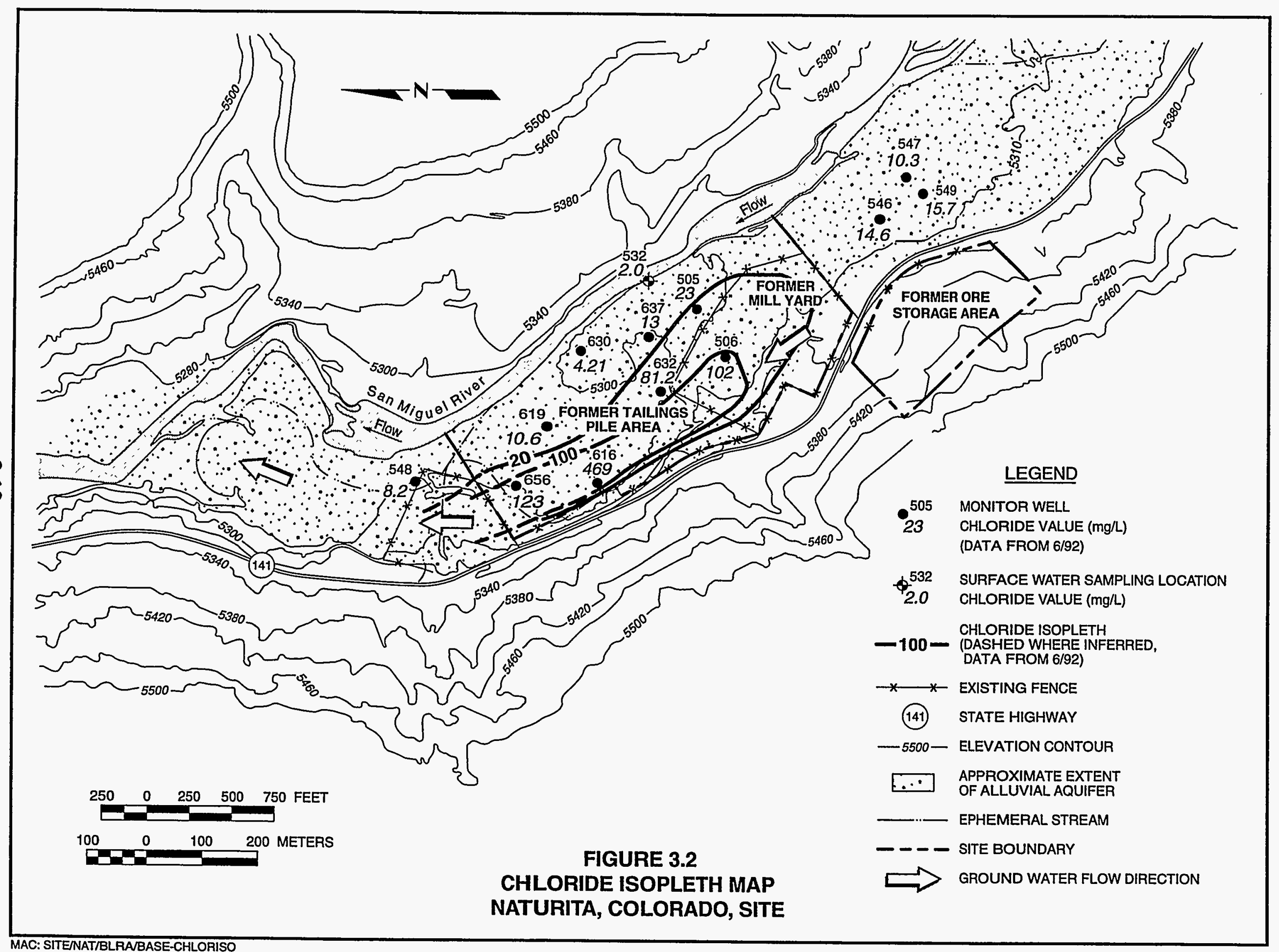




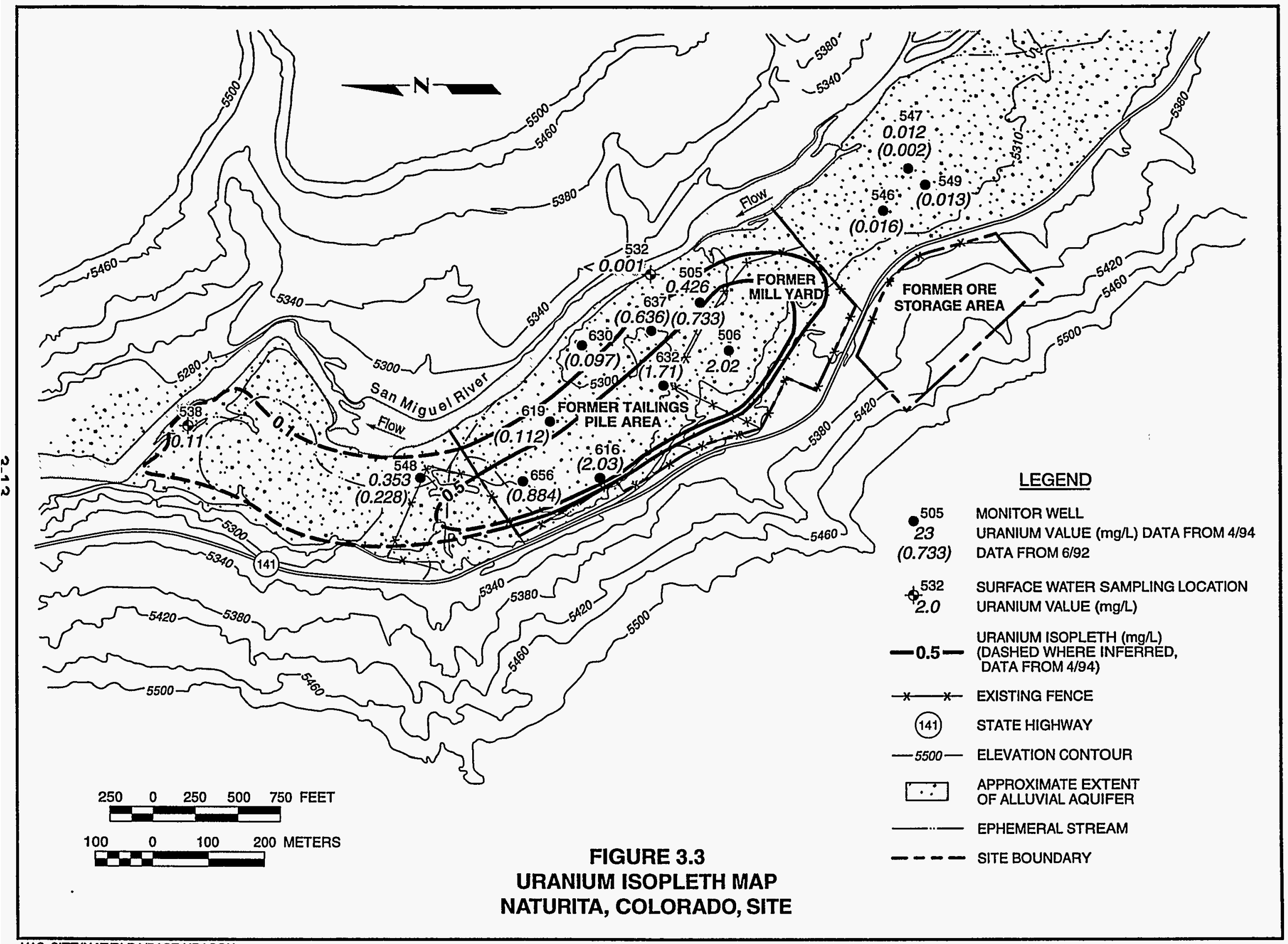




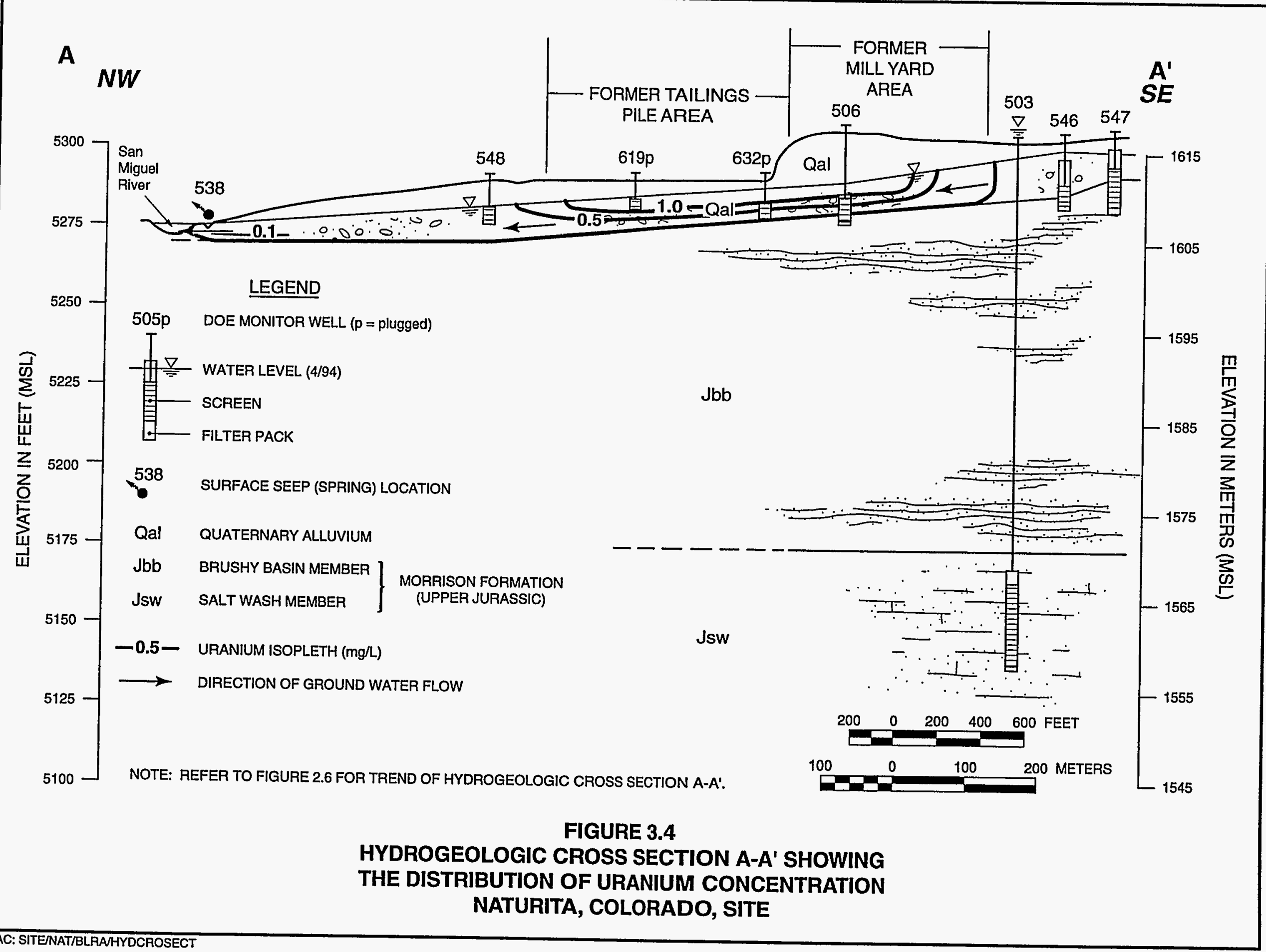


in this figure shows the highest uranium concentrations in the shallower, clayrich alluvium and lower concentrations in the deeper portion of the aquifer, near the interface between the alluvium and the Brushy Basin Member of the Morrison Formation This configuration is the result of a layer of coarse gravel and cobbles observed at the base of the alluvium (Section 2.41. Ground water moves much more quickly through the gravel and cobbles than it does through the clay-rich upper alluvium. Thus, uranium contamination moving down from near the surface tends to be diluted when it reaches the gravel and cobble layer near the bottom of the alluvium.

The above discussion highlights the large number of factors affecting contaminant distribution at the Naturita site. For example, the limited extent of the alluvium at the Naturita site limits the extent of contamination and the composition of the alluvium, ranging from clay-rich to dominantly coarse gravel and cobbles, affects contaminant concentrations. Waste disposal practices at the Naturita site (i.e., location of alkaline and acid leach tailings) also influence contaminant distribution. Additionally, contaminants in ground water move at different rates due to differences in degree of participation in precipitation and adsorption reactions. Thus, contaminant distribution at the Naturita site is not uniform from one constituent to another. It is possible, however, to say that the area with the highest levels of uranium contamination is approximated by the 20 $\mathrm{mg} / \mathrm{L}$ chloride isopleth in Figure 3.2 and the maximum extent of contamination is likely approximated by the $0.1 \mathrm{mg} / \mathrm{L}$ uranium isopleth of Figure 3.3 .

On-site and background ground water quality data collected between 1989 and 1994 were compared to determine constituents that are elevated above background in ground water under the Naturita site. A complete description of the statistical methods used in this assessment is presented in a statistician's report (DOE, 1995a). Statistical testing was conducted at the 0.10 level of significance.

Water quality data from alluvial monitor wells 547 and 549 were used to quantify background ground water quality at the Naturita site. Both wells were sampled seven times between 1989 and 1992. Alluvial monitor well 547 was also sampled in 1994. On-site water quality was represented by alluvial monitor wells 616 and 632. These wells consistently have shown the highest levels of constituents generally associated with uranium milling. Alluvial monitor well 616 was sampled six times and 632 seven times between 1989 and 1992.

The following constituents were eliminated from further assessment because of extremely low frequency of detection in on-site wells: beryllium, cobalt, chromium, copper, cyanide, mercury, nickel, lead, and thallium. For the other monitored constituents, data from the two background wells were pooled together and compared to levels in alluvial monitor well 616, and then to levels in alluvial monitor well 632. The statistical comparison method used was the 
Wilcoxon rank-sum test. If either on-site well comparison was significant at the 0.10 level, the constituent was retained for additional assessment.

The statistical analysis identified 27 constituents that are present at higher concentrations in on-site than in background wells. Table 3.1 summarizes the concentration levels measured in the most contaminated alluvial monitor well(s) on the site, 616 and/or 632, with the exception of manganese and strontium, both of which were measured in higher concentrations in samples from nearby alluvial monitor well 656.

\subsection{CONTAMINANTS OF POTENTIAL CONCERN}

The results of analyses in Section 3.3 were used to compile a list of contaminants of potential concern for the assessment of risks to human health and the environment at the Naturita site. The constituents listed in column one of Table 3.3 are elevated above background levels at the 0.10 level of significance.

These constituents were screened for their potential to affect human health. The screening was based on the range of observed concentrations in filtered ground water samples between July 1989 and April 1994.

Some constituents were screened out because they are essential nutrients present at levels within nutritional ranges even when added to expected dietary ranges (DOE, 1994a; 1995a). These constituents are calcium, magnesium, phosphate, and potassium (Table 3.3, column 2).

The final screening of the remaining constituents was based on their relatively low toxic potency and/or relatively high normal dietary intake by comparison to the values measured, so that levels at which they are observed at the Naturita site would not be associated with adverse health effects even then added to expected dietary intake (DOE, 1994a; 1995a). These constituents are aluminum, ammonium, barium, boron, chloride, fluoride, nitrate, silica, silver, and strontium (Table 3.3, column 3). Although some contaminants have been eliminated from the list of contaminants of potential concern, the potential for their interaction with other contaminants is discussed in Section 5.2.

Based on the screening, antimony, arsenic, manganese, molybdenum, selenium, vanadium, uranium, sodium, sulfate, radium-226 and -228 , lead-210, and polonium-210 were chosen as final contaminants of potential concern for the human health risk assessment at the Naturita site. Although thorium-230 is not statistically above background levels in the alluvial aquifer, it is evaluated in Section 6.0 because thorium-230 is a longer-lived progeny of the uranium decay series. 
Table 3.3 Contaminants of potential concern, Naturita, Colorado, site ${ }^{a}$

\begin{tabular}{|c|c|c|c|}
\hline $\begin{array}{c}\text { Contaminants } \\
\text { exceeding } \\
\text { background levels }\end{array}$ & $\begin{array}{l}\text { Contaminants in } \\
\text { nutritional range }\end{array}$ & $\begin{array}{l}\text { Contaminants of very } \\
\text { low toxic potency at } \\
\text { observed levels and/or } \\
\text { high dietary range }\end{array}$ & $\begin{array}{l}\text { Contaminants of } \\
\text { potential concern }\end{array}$ \\
\hline Aluminum & Calcium & Aluminum & Antimony \\
\hline Ammonium & Magnesium & Ammonium & Arsenic \\
\hline Antimony & Phosphate & Barium & Lead-210 \\
\hline Arsenic & Potassium & Boron & Manganese \\
\hline Barium & & Chloride & Molybdenum \\
\hline Boron & & Fluoride & Polonium-210 \\
\hline Calcium & $\cdot$ & Nitrate & Radium-226 \\
\hline Chloride & & Silica & Radium-228 \\
\hline Fluoride & & Silver & Selenium \\
\hline Lead-210 & & Strontium & Sodium \\
\hline Magnesium & & & Sulfate \\
\hline Manganese & & & Uranium \\
\hline Molybdenum & & & Vanadium \\
\hline \multicolumn{4}{|l|}{ Nitrate } \\
\hline \multicolumn{4}{|l|}{ Phosphate } \\
\hline \multicolumn{4}{|l|}{ Polonium-210 } \\
\hline \multicolumn{4}{|l|}{ Potassium } \\
\hline \multicolumn{4}{|l|}{ Radium-226 } \\
\hline \multicolumn{4}{|l|}{ Radium-228 } \\
\hline Selenium & & & \\
\hline \multicolumn{4}{|l|}{ Silica } \\
\hline \multicolumn{4}{|l|}{ Silver } \\
\hline \multicolumn{4}{|l|}{ Sodium } \\
\hline \multicolumn{4}{|l|}{ Strontium } \\
\hline \multicolumn{4}{|l|}{ Sulfate } \\
\hline \multicolumn{4}{|l|}{ Uranium } \\
\hline Vanadium & & & \\
\hline
\end{tabular}

The screening process starts with the first column; constituents listed in the second and third columns are subtracted from the list of constituents in the first column; the remaining constituents form the list shown in the last column. 
These constituents form the basis of the human health risk assessment for ground water at the Naturita site. Because ecological impacts differ from effects on human health, the complete lists of contaminants (Table 3.3, column 1) are considered for ecological risk assessment in Section 7.0.

\subsection{CONTAMINANT FATE AND TRANSPORT}

Transport of the contaminants in ground water at the Naturita site is by ground water flow in the alluvium. Contaminant mobility, uptake, and toxicity depend on the species of ions that exist in the aqueous environment. The type of ion species and complexes depend on the availability of various anions and cations for the formation of complex ions, and on $\mathrm{pH}$ and Eh (oxidation/reduction potential) conditions. The pH conditions in the alluvium at the Naturita site are near neutral (close to 7). Although the redox state of the ground water is poorly defined, stable species of the contaminants of potential concern have been computed with the geochemical speciation computer program PHREEOE (Parkhurst et al., 1980) using the constituent concentrations (Table 3.1) and pH conditions observed in the most contaminated well and a range of Eh values from 0 to 400 millivolts (DOE, 1995a). This Eh range is reasonable given the overall chemistry of the alluvial aquifer and model results are very similar using either 0 or $\mathbf{4 0 0}$ millivolts. The predominant species and their molar percentages are summarized in Table 3.4 .

\section{Antimony}

Antimony is present at the Naturita site at concentrations of up to $0.043 \mathrm{mg} / \mathrm{L}$, but the median concentration is less than $0.003 \mathrm{mg} / \mathrm{L}$. High concentrations are found directly under the former tailings pile area. All of the known antimony compounds are very soluble; therefore, precipitation of antimony-bearing minerals is not expected to occur. While very little is known about adsorption/desorption behavior of antimony species (Rai and Zachara, 1984), adsorption appears to have attenuated concentrations of this ion at the Naturita site.

\section{Arsenic}

Arsenic is present in amounts up to $0.08 \mathrm{mg} / \mathrm{L}$ in alluvial monitor well 616 at the Naturita site but concentrations never exceed $0.01 \mathrm{mg} / \mathrm{L}$ in downgradient alluvial monitor well 548. This drop in concentrations is due to adsorption onto the aquifer matrix. Thus, data for the Naturita site demonstrate that, with transport and time, arsenic has been greatly attenuated by adsorption, and further attenuation is expected in the future.

\section{Manganese}

Manganese is present in alluvial monitor well 656 in amounts up to $7.5 \mathrm{mg} / \mathrm{L}$. Several samples of ground water at the Naturita site are at or near saturation 
Table 3.4 Stable species of contaminants of potential concern in the ground water system at the Naturita, Colorado, site ${ }^{a}$

\begin{tabular}{|c|c|c|c|c|}
\hline $\begin{array}{c}\text { Contaminant of } \\
\text { potential concern }\end{array}$ & $\begin{array}{l}\text { Valence } \\
\text { state }\end{array}$ & Common name & $\begin{array}{l}\text { Identity of } \\
\text { species } \\
\text { in ground water }\end{array}$ & $\begin{array}{c}\text { Approximate } \\
\text { molar } \\
\text { percentage }\end{array}$ \\
\hline \multirow[t]{2}{*}{ Antimony } & $5+$ & Antimony hexahydroxide & $\mathrm{Sb}(\mathrm{OH})_{6}^{-}$ & Dominant \\
\hline & $3+$ & Antimony trihydroxide & $\mathrm{Sb}(\mathrm{OH})_{3} \mathrm{AQ}$ & Secondary \\
\hline \multirow[t]{2}{*}{ Arsenic } & $5+$ & Hydrogen arsenate & $\mathrm{HAsO}_{4}{ }^{2-}$ & 87 \\
\hline & $5+$ & Dihydrogen arsenate & $\mathrm{H}_{2} \mathrm{AsO}_{4}^{-}$ & 13 \\
\hline \multirow[t]{2}{*}{ Manganese } & $2+$ & Manganese ion & $\mathrm{Mn}^{2+}$ & 72 \\
\hline & $2+$ & Manganese sulfate & $\mathrm{MnSO}_{4} \mathrm{AQ}$ & 21 \\
\hline Molybdenum & $6+$ & Molybdate ion & $\mathrm{MoO}_{4}{ }^{2-}$ & 100 \\
\hline \multirow[t]{2}{*}{ Selenium ${ }^{b}$} & $4+$ & Hydrogen selenite & $\mathrm{HSeO}_{3}^{-}$ & Dominant \\
\hline & $4+$ & Selenite & $\mathrm{SeO}_{3}{ }^{2-}$ & Secondary \\
\hline Sodium & $1+$ & Sodium ion & $\mathrm{Na}^{+}$ & 98 \\
\hline \multirow[t]{4}{*}{ Sulfur } & $6+$ & Sulfate ion & $\mathrm{SO}_{4}{ }^{2-}$ & 82 \\
\hline & $6+$ & Sodium sulfate & $\mathrm{NaSO}_{4}^{-}$ & 7 \\
\hline & $6+$ & Calcium sulfate & $\mathrm{CaSO}_{4} \mathrm{AO}$ & 6 \\
\hline & $6+$ & Magnesium sulfate & $\mathrm{MgSO}_{4} \mathrm{AO}$ & 5 \\
\hline \multirow[t]{3}{*}{ Uranium } & $6+$ & Uranyl tricarbonate & $\mathrm{UO}_{2}\left(\mathrm{CO}_{3}\right)_{3}^{4-}$ & 68 \\
\hline & $6+$ & Uranyl dicarbonate & $\mathrm{UO}_{2}\left(\mathrm{CO}_{3}\right)_{2}^{2-}$ & 22 \\
\hline & $6+$ & Uranyl biphosphate & $\mathrm{UO}_{2}\left(\mathrm{HPO}_{4}\right)_{2}^{2-}$ & 10 \\
\hline \multirow[t]{2}{*}{ Vanadium } & $5+$ & Vanadate & $\mathrm{HV}_{2} \mathrm{O}_{7}^{3-}$ & 94 \\
\hline & $5+$ & Vanadate & $\mathrm{HVO}_{4}{ }^{2-}$ & 5 \\
\hline
\end{tabular}

aqueous species were calculated using the geochemical code PHREEQE (Parkhurst et al., 1980).

binformation for some species was taken from Rai and Zachara (1984). 
with respect to the mineral rhodochrosite $\left(\mathrm{MnCO}_{3}\right)$, and in the past, manganese was probably precipitated out of solution as rhodochrosite. These deposits form a secondary source of manganese that will continue to release manganese in equilibrium amounts (about 1 to $7 \mathrm{mg} / \mathrm{L}$ ) until the solids are completely dissolved. As a result, decreases in concentrations will be due to dilution and dispersion without the benefit of adsorption.

\section{Molybdenum}

Molybdenum is present at concentrations up to about $0.38 \mathrm{mg} / \mathrm{L}$ in alluvial monitor well 616. Molybdenum occurs in the contaminated ground waters as molybdate $\left(\mathrm{MoO}_{4}{ }^{2}\right)$, a negatively charged ion (Table 3.4). As with most negatively charged ions, adsorption of molybdenum is most effective under acidic conditions ( $\mathrm{pH}$ in the 3 to 4 range). Thus, adsorption of molybdenum in the near neutral $\mathrm{pH}$ ground waters at the Naturita site will be less important than dilution as a mechanism for decreasing concentrations.

\section{Selenium}

Selenium occurs at the Naturita site in concentrations of up to $0.08 \mathrm{mg} / \mathrm{L}$. The dominant selenium species in ground water at the Naturita site is hydrogen selenite $\left(\mathrm{HSeO}_{3}\right)$ followed by selenite $\left(\mathrm{SeO}_{3}{ }^{2-}\right)$ (Table 3.4). Adsorption of these selenium anionic species is most effective under acid conditions $(\mathrm{pH}$ less than 4). Thus, under the near neutral pH conditions at the Naturita site, both anionic species are mobile in ground water. Therefore, dilution and dispersion are likely to be the primary mechanisms for reducing selenium concentrations at the Naturita site.

\section{Sodium}

Sodium occurs in alluvial monitor well 616 on the Naturita site in concentrations of up to $1080 \mathrm{mg} / \mathrm{L}$. Concentrations of sodium in down gradient monitor well 548 are near background in the range of $50 \mathrm{mg} / \mathrm{L}$. This distribution is the result of slurrying of the alkaline leach tails on to the eastern half of the former tailings pile area (near alluvial monitor well 616) directly after they had been salt roasted with sodium chloride and leached with sodium bicarbonate. Sodium forms very soluble salts, and precipitation of those salts from ground water will not occur. Thus, dilution and dispersion will play the greatest role in reducing sodium concentrations at the Naturita site.

\section{Sulfate}

Sulfate occurs at concentrations of up to about $1450 \mathrm{mg} / \mathrm{L}$ in alluvial monitor well 616 . The sulfate ion $\left(\mathrm{SO}_{4}{ }^{2-}\right)$ is the dominant sulfur species in ground water at the Naturita site, followed by the sodium sulfate ion $\left(\mathrm{NaSO}_{4}{ }^{\circ}\right)$ and calcium sulfate $\left(\mathrm{CaSO}_{4} \mathrm{AO}\right.$ ) (Table 3.4). Modeling with the computer code PHREEOE (Parkhurst et al. 1980) indicates that gypsum is at equilibrium and should have a tendency to precipitate. These precipitates would then become a secondary 
source of contamination, supplying sulfate to the ground water in equilibrium concentrations $(200-500 \mathrm{mg} / \mathrm{L})$ until solids are completely dissolved.

\section{Uranium}

Uranium occurs at Naturita in concentration levels up to about $5.2 \mathrm{mg} / \mathrm{L}$. Uranium occurs in ground waters at the Naturita site dominantly as a uranyl carbonate ion (for example, $\mathrm{UO}_{2}\left(\mathrm{CO}_{3}\right)_{3}{ }^{4-}$ ) (Table 3.4). This ion is mobile in neutral to alkaline ground waters, and thus, dilution will be the primary control on uranium concentrations as ground water enters the San Miguel River.

\section{Vanadium}

Vanadium occurs at concentrations up to $10 \mathrm{mg} / \mathrm{L}$ in alluvial monitor well 616. With generally oxidizing conditions existing at the Naturita site, vanadium exists in ground waters in its maximum oxidation state $(+5)$ as a vanadate ion (primarily $\mathrm{HV}_{2} \mathrm{O}_{7}{ }^{3-}$ ) (Table 3.4). Little is known about the adsorptive behavior of vanadium species, but vanadates are known to be adsorbed by iron oxides (Rai and Zachara, 1984). Additionally, modeling with PHREEOE (Parkhurst et al., 1980 ) indicates that ground water on the Naturita site is saturated with respect to carnotite (potassium uranium vanadate) and iron vanadate. Thus, the bulk of vanadium contamination has been attenuated at the Naturita site.

\subsection{SURFACE WATER}

The Naturita site is adjacent to the San Miguel River and hydrologic gradients (Sections 2.4 and 2.5) indicate that alluvial aquifer from the Naturita site discharges to the river. Analyses of surface water from three locations along the San Miguel River are available from 1986 through 1994 (Figure 3.5). These include one upstream location, one location adjacent to the Naturita site, and one downstream location. Additionally, two rounds of surface water sampling and one round of sediment sampling were completed in 1994 to support this risk assessment that included one additional up stream and two additional down stream locations (Figure 3.5). The November 1994 sampling period was chosen to coincide with the onset of seasonal low flow in the river since the potential impact of contaminant discharge would be greatest during the low flow period. The results of all surface water sampling and analyses conducted between 1986 and 1994 are summarized in Table 3.5. The seep (surface location 538) that was sampled during November 1994 has been discussed with ground water in Section 3.2.

Results of the November 1994 sediment sampling analyses are presented in Table 3.6. Because there is only one round of sediment data, a rigorous statistical evaluation of sediment data cannot be made. Sediments do not mix as quickly or as completely as water, and rock types can vary widely from location to location making it more difficult to compare upstream and downstream sediment data than it is to compare upstream and downstream surface water data. A qualitative assessment shows that a few constituents 


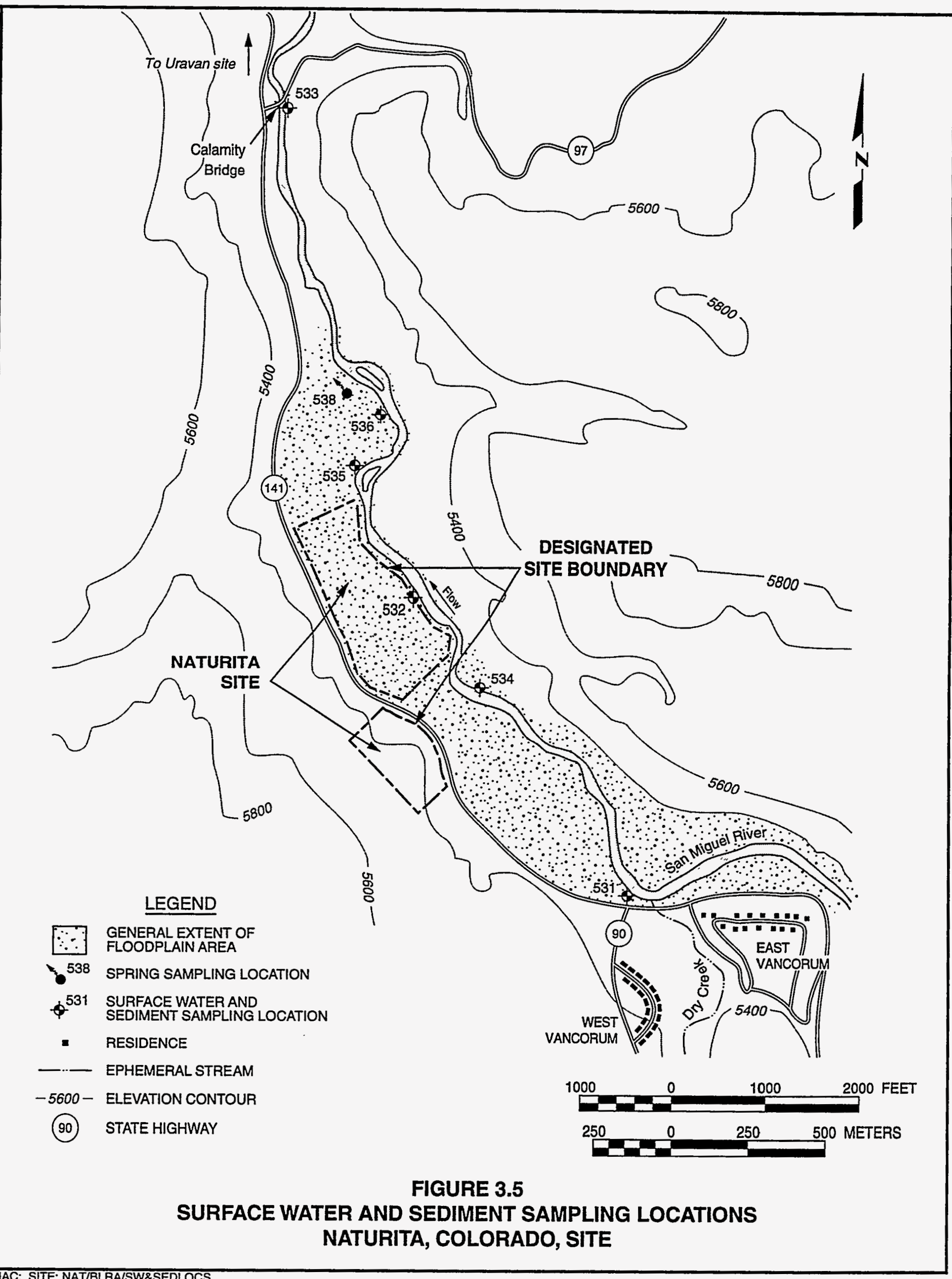


Table 3.5 Comparison of upstream and downstream water quality data for constituents above background in ground water, San Miguel River, Naturita, Colorado, site

\begin{tabular}{|c|c|c|c|c|c|c|}
\hline \multirow[b]{3}{*}{ Constituent } & \multirow{3}{*}{$\begin{array}{c}\text { Location } \\
\text { ID" }\end{array}$} & \multicolumn{4}{|c|}{ Filtered samples } & \multirow{3}{*}{$\begin{array}{c}\begin{array}{c}\text { Unfiltered } \\
\text { samples }\end{array} \\
\text { Maximum } \\
\text { (mg/L) } \\
\end{array}$} \\
\hline & & \multirow{2}{*}{$\begin{array}{c}\text { Frequency of } \\
\text { detection }\end{array}$} & Minimum & Median' & Maximum & \\
\hline & & & \multicolumn{3}{|c|}{ (mg/L) } & \\
\hline \multicolumn{7}{|c|}{ Chemical (inorganics) } \\
\hline \multicolumn{7}{|c|}{ Aluminum } \\
\hline $\begin{array}{l}\text { Upstream } \\
\text { Downstream } \\
\text { Downstream }\end{array}$ & $\begin{array}{l}531 \\
532 \\
533\end{array}$ & $\begin{array}{l}3 / 8 \\
3 / 8 \\
3 / 8\end{array}$ & $\begin{array}{l}<0.05 \\
<0.05 \\
<0.05\end{array}$ & $\begin{array}{l}<0.10 \\
<0.10 \\
<0.10\end{array}$ & $\begin{array}{l}0.50 \\
0.30 \\
0.50\end{array}$ & $\begin{array}{l}2.35 \\
2.10 \\
2.20\end{array}$ \\
\hline \multicolumn{7}{|l|}{ Antimony } \\
\hline $\begin{array}{l}\text { Upstream } \\
\text { Downstream } \\
\text { Downstream } \\
\text { Upstream } \\
\text { Downstream } \\
\text { Downstream }\end{array}$ & $\begin{array}{l}531 \\
532 \\
533 \\
534 \\
535 \\
536\end{array}$ & $\begin{array}{l}2 / 8 \\
0 / 9 \\
1 / 8 \\
0 / 2 \\
1 / 2 \\
0 / 2\end{array}$ & $\begin{array}{l}<0.003 \\
<0.003 \\
<0.003 \\
<0.003 \\
<0.003 \\
<0.003\end{array}$ & $\begin{array}{l}<0.003 \\
<0.003 \\
<0.003 \\
<0.003 \\
<0.003 \\
<0.003\end{array}$ & $\begin{array}{r}0.007 \\
<0.003 \\
0.003 \\
<0.003 \\
0.003 \\
<0.003\end{array}$ & $\begin{array}{l}0.005 \\
<0.003 \\
<0.003 \\
\text { NA } \\
\text { NA } \\
\text { NA }\end{array}$ \\
\hline \multicolumn{7}{|l|}{ Arsenic } \\
\hline $\begin{array}{l}\text { Upstream } \\
\text { Downstream } \\
\text { Downstream } \\
\text { Upstream } \\
\text { Downstream } \\
\text { Downstream }\end{array}$ & $\begin{array}{l}531 \\
532 \\
533 \\
534 \\
535 \\
536\end{array}$ & $\begin{array}{l}2 / 11 \\
1 / 11 \\
2 / 11 \\
0 / 2 \\
0 / 2 \\
0 / 2\end{array}$ & $\begin{array}{r}0.002 \\
<0.001 \\
0.001 \\
<0.005 \\
<0.005 \\
<0.005\end{array}$ & $\begin{array}{l}<0.01 \\
<0.01 \\
<0.01 \\
<0.005 \\
<0.005 \\
<0.005\end{array}$ & $\begin{array}{l}<0.01 \\
<0.01 \\
<0.01 \\
<0.005 \\
<0.005 \\
<0.005\end{array}$ & $\begin{array}{c}<0.01 \\
<0.01 \\
<0.01 \\
0.005 \\
0.005 \\
0.005\end{array}$ \\
\hline \multicolumn{7}{|l|}{ Barium } \\
\hline $\begin{array}{l}\text { Upstream } \\
\text { Downstream } \\
\text { Downstream }\end{array}$ & $\begin{array}{l}531 \\
532 \\
533\end{array}$ & $\begin{array}{l}3 / 7 \\
4 / 8 \\
3 / 7\end{array}$ & $\begin{array}{l}0.05 \\
0.05 \\
0.05\end{array}$ & $\begin{array}{l}<0.10 \\
<0.10 \\
<0.10\end{array}$ & $\begin{array}{r}<0.10 \\
0.30 \\
<0.10\end{array}$ & $\begin{array}{l}0.11 \\
0.10 \\
0.24\end{array}$ \\
\hline \multicolumn{7}{|l|}{ Boron } \\
\hline $\begin{array}{l}\text { Upstream } \\
\text { Downstream } \\
\text { Downstream }\end{array}$ & $\begin{array}{l}531 \\
532 \\
533\end{array}$ & $\begin{array}{l}1 / 3 \\
1 / 4 \\
1 / 3\end{array}$ & $\begin{array}{l}<0.10 \\
<0.10 \\
<0.10\end{array}$ & $\begin{array}{l}<0.10 \\
<0.10 \\
<0.10\end{array}$ & $\begin{array}{l}0.13 \\
0.10 \\
0.11\end{array}$ & $\begin{array}{l}<0.10 \\
<0.10 \\
<0.10\end{array}$ \\
\hline \multicolumn{7}{|l|}{ Calcium } \\
\hline $\begin{array}{l}\text { Upstream } \\
\text { Downstream } \\
\text { Downstream } \\
\text { Upstream } \\
\text { Downstream } \\
\text { Downstream } \\
\end{array}$ & $\begin{array}{l}531 \\
532 \\
533 \\
534 \\
535 \\
536 \\
\end{array}$ & $\begin{array}{l}11 / 11 \\
11 / 11 \\
11 / 11 \\
2 / 2 \\
2 / 2 \\
2 / 2 \\
\end{array}$ & $\begin{array}{l}41 \\
41 \\
29 \\
40.6 \\
40.0 \\
40.0 \\
\end{array}$ & $\begin{array}{l}80 \\
79 \\
79 \\
64.8 \\
66.8 \\
65.1 \\
\end{array}$ & $\begin{array}{c}121 \\
107 \\
115 \\
88.9 \\
93.6 \\
90.1 \\
\end{array}$ & $\begin{array}{l}96 \\
86 \\
87 \\
\text { NA } \\
\text { NA } \\
\text { NA }\end{array}$ \\
\hline
\end{tabular}


Table 3.5 Comparison of upstream and downstream water quality data for constituents above background in ground water, San Miguel River, Naturita, Colorado, site (Continued)

\begin{tabular}{|c|c|c|c|c|c|c|}
\hline \multirow[b]{3}{*}{ Constituent } & \multirow{3}{*}{$\begin{array}{c}\text { Location } \\
10^{*}\end{array}$} & \multicolumn{4}{|c|}{ Filtered samples } & \multirow{3}{*}{$\begin{array}{c}\begin{array}{c}\text { Unfiltered } \\
\text { samples }\end{array} \\
\text { Maximum } \\
\text { (mg/L) }\end{array}$} \\
\hline & & \multirow{2}{*}{$\begin{array}{c}\text { Frequency of } \\
\text { detection }^{b}\end{array}$} & Minimum & Median ${ }^{\circ}$ & Maximum & \\
\hline & & & \multicolumn{3}{|c|}{ (mg/L) } & \\
\hline \multicolumn{7}{|l|}{ Chloride } \\
\hline Upstream & 531 & $11 / 11$ & 1.7 & 4.4 & 15 & 7.0 \\
\hline Downstream & 532 & $11 / 11$ & 1.0 & 4.1 & 14 & 7.0 \\
\hline Downstream & 533 & $11 / 11$ & 1.8 & 3.7 & 13 & 6.0 \\
\hline Upstream & 534 & $2 / 2$ & 2.2 & 3.1 & 4.0 & NA \\
\hline Downstream & 535 & $2 / 2$ & 1.9 & 2.9 & 3.8 & NA \\
\hline Downstream & 536 & $2 / 2$ & 2.0 & 2.8 & 3.6 & NA \\
\hline \multicolumn{7}{|l|}{ Fluoride } \\
\hline Upstream & 531 & $8 / 9$ & $<0.10$ & 0.30 & 0.40 & 0.30 \\
\hline Downstream & 532 & $9 / 10$ & $<0.10$ & 0.27 & 0.40 & 0.30 \\
\hline Downstream & 533 & $8 / 9$ & $<0.10$ & 0.30 & 0.40 & 0.30 \\
\hline \multicolumn{7}{|l|}{ Magnesium } \\
\hline Upstream & 531 & $11 / 11$ & 8.1 & 21 & 53 & 28 \\
\hline Downstream & 532 & $11 / 11$ & 8.2 & 17 & 45 & 27 \\
\hline Downstream & 533 & $11 / 11$ & 6.2 & 18 & 48 & 25 \\
\hline Upstream & 534 & $2 / 2$ & 7.9 & 15 & 23 & NA \\
\hline Downstream & 535 & $2 / 2$ & 8.3 & 16 & 24 & NA \\
\hline Downstream & 536 & $2 / 2$ & 8.0 & 15 & 22 & NA \\
\hline \multicolumn{7}{|l|}{ Manganese } \\
\hline Upstream & 531 & $11 / 11$ & 0.01 & 0.03 & 0.05 & 0.15 \\
\hline Downstream & 532 & $11 / 11$ & 0.01 & 0.02 & 0.06 & 0.13 \\
\hline Downstream & 533 & $11 / 11$ & 0.01 & 0.02 & 0.10 & 0.20 \\
\hline Upstream & 534 & $1 / 2$ & $<0.01$ & $<0.02$ & 0.02 & 0.13 \\
\hline Downstream & 535 & $2 / 2$ & 0.01 & 0.02 & 0.02 & 0.10 \\
\hline Downstream & 536 & $2 / 2$ & 0.01 & 0.02 & 0.02 & 0.18 \\
\hline \multicolumn{7}{|l|}{ Molybdenum } \\
\hline $\begin{array}{l}\text { Upstream } \\
\text { Downstream }\end{array}$ & $\begin{array}{l}531 \\
532\end{array}$ & $\begin{array}{l}3 / 11 \\
3 / 11\end{array}$ & $\begin{array}{l}<0.01 \\
<0.01\end{array}$ & $\begin{array}{l}<0.01 \\
<0.01\end{array}$ & $\begin{array}{l}0.26 \\
0.27\end{array}$ & $\begin{array}{l}<0.01 \\
<0.01\end{array}$ \\
\hline Downstream & 533 & $3 / 11$ & $<0.01$ & $<0.01$ & 0.20 & $<0.01$ \\
\hline Upstream & 534 & $0 / 2$ & $<0.01$ & $<0.01$ & $<0.01$ & $<0.01$ \\
\hline Downstream & 535 & $0 / 2$ & $<0.01$ & $<0.01$ & $<0.01$ & $<0.01$ \\
\hline Downstream & 536 & $0 / 2$ & $<0.01$ & $<0.01$ & $<0.01$ & $<0.01$ \\
\hline
\end{tabular}


Table 3.5 Comparison of upstream and downstream water quality data for constituents above background in ground water, San Miguel River, Naturita, Colorado, site (Continued)

\begin{tabular}{|c|c|c|c|c|c|c|}
\hline \multirow[b]{3}{*}{ Constituent } & \multirow{3}{*}{$\begin{array}{c}\text { Location } \\
\text { ID }\end{array}$} & \multicolumn{4}{|c|}{ Filtered samples } & \multirow{3}{*}{$\begin{array}{c}\begin{array}{c}\text { Unfiltered } \\
\text { samples }\end{array} \\
\text { Maximum } \\
\text { (mg/L) }\end{array}$} \\
\hline & & \multirow{2}{*}{$\begin{array}{c}\text { Frequency of } \\
\text { detection }^{b}\end{array}$} & Minimum & Median ${ }^{c}$ & Maximum & \\
\hline & & & \multicolumn{3}{|c|}{$(\mathrm{mg} / \mathrm{L})$} & \\
\hline \multicolumn{7}{|l|}{ Potassium } \\
\hline Upstream & 531 & $9 / 10$ & 1.2 & 1.7 & 3.2 & 3.1 \\
\hline Downstream & 532 & $9 / 10$ & 1.2 & 1.7 & 2.9 & 3.1 \\
\hline Downstream & 533 & $9 / 10$ & 1.3 & 1.9 & 3.1 & 2.8 \\
\hline Upstream & 534 & $1 / 1$ & NA & 1.7 & NA & NA \\
\hline Downstream & 535 & $1 / 1$ & NA & 1.7 & NA & NA \\
\hline Downstream & 536 & $1 / 1$ & NA & 1.7 & NA & NA \\
\hline \multicolumn{7}{|l|}{ Selenium } \\
\hline Upstream & 531 & $1 / 10$ & $<0.002$ & $<0.005$ & 0.004 & $<0.005$ \\
\hline Downstream & 532 & $1 / 11$ & $<0.002$ & $<0.005$ & 0.002 & $<0.005$ \\
\hline Downstream & 533 & $1 / 11$ & $<0.002$ & $<0.005$ & 0.003 & $<0.005$ \\
\hline Upstream & 534 & $0 / 2$ & $<0.005$ & $<0.005$ & $<0.005$ & $<0.005$ \\
\hline Downstream & 535 & $0 / 2$ & $<0.005$ & $<0.005$ & $<0.005$ & $<0.005$ \\
\hline Downstream & 536 & $0 / 2$ & $<0.005$ & $<0.005$ & $<0.005$ & $<0.005$ \\
\hline \multicolumn{7}{|l|}{ Silica } \\
\hline Upstream & 531 & $3 / 3$ & 7.7 & 8.0 & 8.3 & 8.0 \\
\hline Downstream & 532 & $4 / 4$ & 3.0 & 7.7 & 8.5 & 10.0 \\
\hline Downstream & 533 & $3 / 3$ & 7.7 & 8.0 & 8.5 & 8.0 \\
\hline \multicolumn{7}{|l|}{ Silver } \\
\hline Upstream & 531 & $1 / 7$ & $<0.01$ & $<0.01$ & 0.020 & $<0.01$ \\
\hline Downstream & 532 & $1 / 8$ & $<0.01$ & $<0.01$ & 0.014 & $<0.01$ \\
\hline Downstream & 533 & $1 / 7$ & $<0.01$ & $<0.01$ & 0.013 & $<0.01$ \\
\hline \multicolumn{7}{|l|}{ Sodium } \\
\hline Upstream & 531 & $10 / 10$ & 7.0 & 21 & 100 & 30 \\
\hline Downstream & 532 & $10 / 10$ & 7.0 & 21 & 42 & 29 \\
\hline Downstream & 533 & $10 / 10$ & 7.0 & 22 & 100 & 28 \\
\hline Upstream & 534 & $1 / 1$ & NA & 6 & NA & NA \\
\hline Downstream & 535 & $1 / 1$ & NA & 7 & NA & NA \\
\hline Downstream & 536 & $1 / 1$ & NA & 7 & NA & NA \\
\hline \multicolumn{7}{|l|}{ Strontium } \\
\hline Upstream & 531 & $8 / 8$ & 0.37 & 0.90 & 1.2 & 1.1 \\
\hline Downstream & 532 & $8 / 8$ & 0.35 & 0.93 & 1.2 & 1.1 \\
\hline Downstream & 533 & $8 / 8$ & 0.34 & 0.93 & 1.2 & 1.1 \\
\hline Upstréam & 534 & $2 / 2$ & 0.34 & 1.45 & 1.11 & 0.36 \\
\hline Downstream & 535 & $2 / 2$ & 0.35 & 0.77 & 1.19 & 0.36 \\
\hline Downstream & 536 & $2 / 2$ & 0.34 & 0.77 & 1.10 & 0.38 \\
\hline
\end{tabular}


Table 3.5 Comparison of upstream and downstream water quality data for constituents above background in ground water, San Miguel River, Naturita, Colorado, site (Continued)

\begin{tabular}{|c|c|c|c|c|c|c|}
\hline \multirow[b]{3}{*}{ Constituent } & \multirow{3}{*}{$\begin{array}{c}\text { Location } \\
\text { ID" }\end{array}$} & \multicolumn{4}{|c|}{ Filtered samples } & \multirow{3}{*}{$\begin{array}{c}\begin{array}{c}\text { Unfiltered } \\
\text { samples } \\
\text { Maximum }\end{array} \\
\text { (mg/L) }\end{array}$} \\
\hline & & \multirow{2}{*}{$\begin{array}{c}\text { Frequency of } \\
\text { detection }^{b}\end{array}$} & Minimum & Median & Maximum & \\
\hline & & & \multicolumn{3}{|c|}{$(\mathrm{mg} / \mathrm{L})$} & \\
\hline \multicolumn{7}{|l|}{ Sulfate } \\
\hline Upstream & 531 & $11 / 11$ & 60 & 193 & 380 & 255 \\
\hline Downstream & 532 & $11 / 11$ & 59 & 146 & 319 & 253 \\
\hline Downstream & 533 & $11 / 11$ & 56 & 178 & 337 & 242 \\
\hline Upstream & 534 & $2 / 2$ & 56 & 38 & 193 & NA \\
\hline Downstream & 535 & $2 / 2$ & 55 & 132 & 208 & NA \\
\hline Downstream & 536 & $2 / 2$ & 60 & 125 & 190 & NA \\
\hline \multicolumn{7}{|l|}{ Uranium } \\
\hline Upstream & 531 & $9 / 11$ & $<0.001$ & 0.002 & 0.017 & 0.003 \\
\hline Downstream & 532 & $9 / 11$ & $<0.001$ & 0.002 & 0.006 & 0.002 \\
\hline Downstream & 533 & $9 / 11$ & $<0.001$ & 0.001 & 0.003 & 0.003 \\
\hline Upstream & 534 & $1 / 2$ & $<0.001$ & $<0.002$ & 0.002 & $<0.001$ \\
\hline Downstream & 535 & $1 / 2$ & $<0.001$ & $<0.002$ & 0.002 & $<0.001$ \\
\hline Downstream & 536 & $1 / 2$ & $<0.001$ & $<0.001$ & 0.001 & $<0.001$ \\
\hline \multicolumn{7}{|l|}{ Vanadium } \\
\hline Upstream & 531 & $5 / 10$ & $<0.01$ & $<0.02$ & 0.34 & $<0.01$ \\
\hline Downstream & 532 & $5 / 10$ & $<0.01$ & $<0.01$ & 0.20 & $<0.01$ \\
\hline Downstream & 533 & $5 / 10$ & $<0.01$ & $<0.01$ & 0.42 & $<0.01$ \\
\hline Upstream & 534 & $0 / 2$ & $<0.01$ & $<0.01$ & $<0.01$ & $<0.01$ \\
\hline Downstream & 535 & $0 / 2$ & $<0.01$ & $<0.01$ & $<0.01$ & $<0.01$ \\
\hline Downstream & 536 & $0 / 2$ & $<0.01$ & $<0.01$ & $<0.01$ & $<0.01$ \\
\hline
\end{tabular}


Table 3.5 Comparison of upstream and downstream water quality data for constituents above background in ground water, San Miguel River, Naturita, Colorado, site - (Continued)

\begin{tabular}{|c|c|c|c|c|c|c|}
\hline \multirow[b]{3}{*}{ Constituent } & \multirow{3}{*}{$\begin{array}{c}\text { Location } \\
\text { ID }\end{array}$} & \multicolumn{4}{|c|}{ Filtered samples } & \multirow{3}{*}{$\begin{array}{c}\begin{array}{c}\text { Unfiltered } \\
\text { samples } \\
\text { Maximum }\end{array} \\
\text { (pCi/L) }\end{array}$} \\
\hline & & \multirow{2}{*}{$\begin{array}{c}\text { Number of } \\
\text { samples }^{b}\end{array}$} & Minimum & Median" & Maximum & \\
\hline & & & \multicolumn{3}{|c|}{$(p C i / L)$} & \\
\hline \multicolumn{7}{|l|}{$\begin{array}{l}\text { Radionuclides } \\
\text { Lead-210 }\end{array}$} \\
\hline Upstream & 531 & 2 & 0.0 & 0.1 & 0.2 & 0.0 \\
\hline Downstream & 532 & 3 & 0.0 & 0.4 & 1.2 & 0.3 \\
\hline Downstream & 533 & 2 & 0.0 & 0.0 & 0.0 & 0.4 \\
\hline Upstream & 534 & $\overline{1}$ & NA & NA & NA & 1.7 \\
\hline Downstream & 535 & 1 & NA & NA & NA & 2.4 \\
\hline Downstream & 536 & 1 & NA & NA & NA & 0.3 \\
\hline \multicolumn{7}{|l|}{ Polonium-210 } \\
\hline Upstream & 531 & 2 & 0.0 & 0.1 & 0.2 & 0.6 \\
\hline Downstream & 532 & 3 & 0.0 & 0.0 & 0.0 & 0.0 \\
\hline Downstream & 533 & 2 & 0.0 & 0.0 & 0.0 & 0.8 \\
\hline Upstream & 534 & 0 & NA & NA & NA & 0.0 \\
\hline Downstream & 535 & 0 & NA & NA & NA & 0.0 \\
\hline Downstream & 536 & 0 & NA & NA & NA & 0.0 \\
\hline \multicolumn{7}{|l|}{ Radium-226 } \\
\hline Upstream & 531 & 8 & 0.0 & 0.1 & 0.1 & 0.3 \\
\hline Downstream & 532 & 9 & 0.0 & 0.1 & 0.4 & 0.4 \\
\hline Downstream & 533 & 8 & 0.0 & 0.1 & 0.6 & 0.2 \\
\hline Upstream & 534 & 1 & NA & 0.1 & NA & 0.1 \\
\hline Downstream & 535 & 1 & NA & 0.1 & NA & 0.0 \\
\hline Downstream & 536 & 1 & NA & 0.1 & NA & 0.5 \\
\hline \multicolumn{7}{|l|}{ Radium-228 } \\
\hline Upstream & 531 & 8 & 0.0 & 0.0 & 1.1 & 2.8 \\
\hline Downstream & 532 & 9 & 0.0 & 0.4 & 23 & 11.5 \\
\hline Downstream & 533 & 8 & 0.0 & 0.4 & 0.9 & 3.3 \\
\hline Upstream & 534 & 1 & NA & 0.0 & NA & NA \\
\hline Downstream & 535 & 1 & NA & 3.6 & NA & NA \\
\hline Downstream & 536 & 1 & NA & 0.0 & NA & NA \\
\hline
\end{tabular}


Table 3.5 Comparison of upstream and downstream water quality data for constituents above background in ground water, San Miguel River, Naturita, Colorado, site (Concluded)

\begin{tabular}{|c|c|c|c|c|c|c|}
\hline \multirow[b]{3}{*}{ Constituent } & \multirow{3}{*}{$\begin{array}{c}\text { Location } \\
\text { ID" }\end{array}$} & \multicolumn{4}{|c|}{ Filtered samples } & \multirow{3}{*}{ 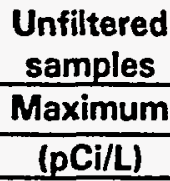 } \\
\hline & & \multirow{2}{*}{$\begin{array}{c}\text { Number of } \\
\text { samples }^{b}\end{array}$} & Minimum & Median $^{\circ}$ & Maximum & \\
\hline & & & \multicolumn{3}{|c|}{$(p C i / L)$} & \\
\hline \multicolumn{7}{|l|}{ Thorium-230 } \\
\hline Upstream & 531 & 2 & 0.0 & 0.1 & 0.1 & 0.2 \\
\hline Downstream & 532 & 3 & 0.1 & 0.1 & 0.5 & 0.3 \\
\hline Downstream & 533 & 2 & 0.0 & 0.1 & 0.1 & 0.2 \\
\hline Upstream & 534 & 0 & NA & NA & NA & 0.1 \\
\hline Downstream & 535 & 0 & NA & NA & NA & 8.6 \\
\hline Downstream & 536 & 0 & NA & NA & NA & 0.3 \\
\hline
\end{tabular}

${ }^{\circ}$ Frequency of detection = number of samples reported at or above the detection limit divided by the total number of samples.

'Median is the 50th percentile of the data. For parameters having only one round of sampling data, the single reported value is listed in the median column. When there is an even number of samples, the median is the average of the two middle data values.

'Locations 531, 532, 533 were sampled from January 1986 to November 1994. Locations 534, 535, 536 were sampled in April and November 1994.

NA - not available. 


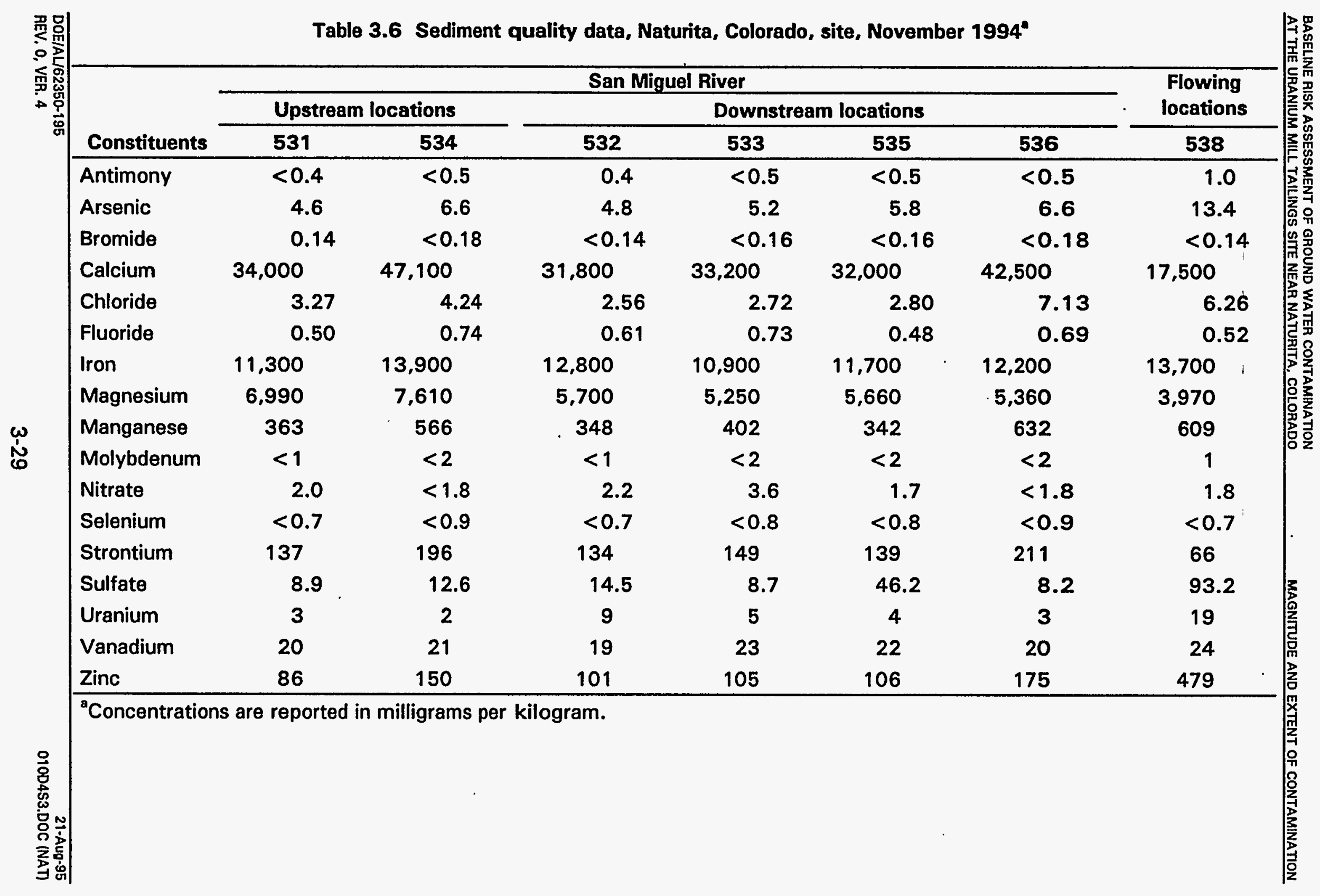


appear to be higher in downstream sediment locations than in upstream sediment locations. For example, upstream uranium values average 2.5 parts per million $(\mathrm{ppm})$ and downstream values average $5.2 \mathrm{ppm}$. Sulfate values average $10.7 \mathrm{ppm}$ upstream and $19.4 \mathrm{ppm}$ downstream. However, these values are low and uranium values compare well with average uranium values in crustal rocks of 2.7 to $5 \mathrm{ppm}$ (Krauskopf, 1979). Thus, it is difficult to attribute differences in so small a data set to influence from the Naturita site. More data would have to be collected to characterize the impact of the Naturita site on sediments in the San Miguel River, although it is possible that even with more data, the impact of the Naturita site on the river may not be clear. The zinc concentration in sediment at the spring location (538) is higher than sediment concentrations at the river locations and an order of magnitude higher than the average crustal abundance (Friberg et al., 1986). While it is difficult to interpret a single measurement, it is unlikely that zinc concentrations in sediment are site related because zinc concentrations in contaminated ground water are low (Table 3.1).

Water quality of the San Miguel River in the vicinity of the Naturita site is dominated by calcium and sulfate, with total dissolved solids concentrations fluctuating from near $200 \mathrm{mg} / \mathrm{L}$ up to $800 \mathrm{mg} / \mathrm{L}$ depending on the time of year. Statistical evaluation of 12 rounds of data from filtered and unfiltered water samples at surface locations 531,532 , and 533 identified no statistically significant elevations in downstream concentrations of the major cations, anions, or trace metals, including uranium. However, radium-226 concentrations in water samples from surface location 532 , immediately adjacent to the former tailings pile area, were statistically higher than samples from the upstream location 531. The actual difference between the two locations is small, with medians of 0.0 and $0.1 \mathrm{pCi} / \mathrm{L}$ from locations 531 and 532 , respectively.

The possible presence of additional radionuclides (thorium-230, polonium-210 and lead-210) in the river water adjacent to the Naturita site could not be assessed statistically at the present time because fewer data are available for these constituents. The chemical analysis results of water and sediment samples collected at the three new surface locations are insufficient to allow for statistical evaluation. Additional water and sediment data would be necessary to determine if the San Miguel River water quality is being affected by site contaminants. If the river is, in fact, being affected by the Naturita site, the mostly likely source is wind-blown tailings, because, as discussed below, the source is unlikely to be contaminated ground water originating under the Naturita site.

\section{Ground water discharge calculations}

In order to estimate the potential for contamination from the Naturita site to have an impact on water quality in the San Miguel River, mass balance calculations were performed. The calculations used the highest concentration of each potential contaminant ever observed in ground water at the Naturita site and a statistical estimate of 20 year low flow conditions in the San Miguel River of $20 \mathrm{ft}^{3}\left(0.6 \mathrm{~m}^{3)}\right.$ per second (see Section 2.5). Note that the statistical low 
flow rate for the river is far lower than the average yearly rate of $330 \mathrm{ft}^{3}$ $\left(9.3 \mathrm{~m}^{3}\right)$ per second. Under these assumptions, ground water from the Naturita site would proportionally contribute the greatest amount of contamination to the river.

These calculations are considered to be conservative. The calculations probably overestimate the effect of contaminated ground water. The high concentration of constituents observed in the ground water at the former tailings pile area would be subject to dispersion and dilution effects during the nearly one half mile $(0.8 \mathrm{~km})$ of travel required for them to be discharged near the spring location 538 (Figure 3.3). Furthermore, many contaminants are retarded or naturally attenuated by precipitation or adsorption onto the aquifer matrix. Thus, concentrations that actually reached the San Miguel River would be a fraction of initial concentrations.

The results of the mass balance calculations indicate that, using current methods and detection limits, only sodium, sulfate, and uranium could produce an increase in concentration above the analysis method detection limit (DOE, 1995a) and these changes would be trivial (Table 3.7).

Sulfate concentrations changes are similar to those for sodium. Uranium concentrations could increase by $0.001 \mathrm{mg} / \mathrm{L}$ during low flow conditions, an amount equal to the detection limit for uranium. No other constituent, including antimony, arsenic, manganese, molybdenum, selenium, vanadium, radium-226, radium-228, lead-210, and polonium-210 has the potential for measurable increases in river concentrations under statistical lowest flow conditions (Table 3.7). Thus, during conditions represented by statistical low flow, contaminated ground water at the Naturita site would not affect the quality of surface water in the San Miguel River. 
Table 3.7 Results of mass balance calculations showing calculated changes in concentrations of contaminants of potential concern in the San Miguel River attributable to ground water flowing from the Naturita, Colorado, site

\begin{tabular}{|c|c|c|c|c|}
\hline & $\begin{array}{l}\text { Maximum observed } \\
\text { concentration in } \\
\text { ground water at } \\
\text { the mill tailings }\end{array}$ & $\begin{array}{c}\text { Computed change } \\
\text { in surface water } \\
\text { concentrations } \\
\text { caused by ground } \\
\text { water discharge } \\
\text { into low flow } \\
\text { conditions in San } \\
\text { Miguel River } \\
\left(20 \mathrm{ft}^{3} / \mathrm{s} 0.6 \mathrm{~m}^{3} / \mathrm{s}\right) \\
\end{array}$ & $\begin{array}{c}\text { Computed change in } \\
\text { surface water } \\
\text { concentrations } \\
\text { caused by ground } \\
\text { water discharge into } \\
\text { average flow of the } \\
\text { San Miguel River } \\
\left(330 \mathrm{ft}^{3} / \mathrm{s}\right. \\
\left.9.3 \mathrm{~m}^{3} / \mathrm{s}\right) \\
\end{array}$ & $\begin{array}{l}\text { Lowest detection } \\
\text { limits for current } \\
\text { UMTRA Project } \\
\text { data from the } \\
\text { Naturita site }\end{array}$ \\
\hline Contaminant & area" & & $(\mathrm{mg} / \mathrm{L})$ & \\
\hline Antimony & 0.043 & 0.000009 & 0.0000005 & 0.003 \\
\hline Arsenic & 0.08 & 0.00002 & 0.000001 & 0.005 \\
\hline Manganese & 7.5 & 0.001 & 0.00009 & 0.01 \\
\hline Molybdenum & 0.38 & 0.00008 & 0.000005 & 0.01 \\
\hline Selenium & 0.08 & 0.00002 & 0.000001 & 0.005 \\
\hline Sodium & 1080 & 0.2 & 0.01 & 0.002 \\
\hline Sulfate & 1450 & 0.3 & 0.02 & 0.1 \\
\hline Uranium & 5.2 & 0.001 & 0.00006 & 0.001 \\
\hline Vanadium & 10 & 0.002 & 0.0001 & 0.01 \\
\hline Radium-226 ${ }^{\mathrm{b}}$ & 11 & 0.002 & 0.0001 & 1.0 \\
\hline Radium-228 & 9 & 0.002 & 0.0001 & 1.0 \\
\hline Lead-210 & 8.4 & 0.002 & 0.0001 & 1.5 \\
\hline Polonium-210 & 4.5 & 0.0009 & 0.00005 & 1.0 \\
\hline
\end{tabular}

Maximum concentration observed in ground water at the former tailings pile area. Values are for filtered ground water samples. Units are $\mathrm{mg} / \mathrm{L}$.

'These values are in $\mathrm{pCi} / \mathrm{L}$ 


\subsection{EXPOSURE ASSESSMENT}

Exposure can occur only if there are both a source of contamination and a mechanism of transport to a receptor population or individual. This section discusses the environmental interactions of affected media, exposure pathways and potential receptor scenarios (Figure 4.1). This section also quantifies the possible exposures that could be incurred by current or future residents, recreational users, and others who could use contaminated ground water or surface water at the Naturita uranium ore processing site. Direct exposures and resulting toxicities for livestock and other environmental receptors are evaluated in Section 7.0.

\subsection{POTENTIALLY EXPOSED POPULATION}

As discussed in Section 2.4 and 3.2, contaminants related to former mill operations are limited in extent to ground water in the alluvial aquifer. The downgradient extent of the alluvial aquifer and hence the extent of contamination is limited to the northwest trending San Miguel River channel about $3500 \mathrm{ft}(1000 \mathrm{~m})$ north of the former mill yard. North of the Naturita site, most of the ground water in the alluvial aquifer discharges to the San Miguel River, where it is quickly diluted. It is likely however, that some underflow exists where the alluvial aquifer is present beneath the river channel at the Naturita site. However, because of limited saturated thickness of the alluvial aquifer (approximately 6 to $13 \mathrm{ft}$ [2 to $4 \mathrm{~m}$ ]), the significance of underflow may be minor, given the probability of a reduced aquifer thickness beneath the river channel. The alluvial aquifer is bounded to the east by the river and to the west by low permeability rocks of the Brushy Basin Member. Therefore, ground water contaminated by the Naturita site in the alluvial aquifer is assumed to constitute all of the potential points of exposure downgradient of the Naturita site.

Ground water contaminated by uranium ore processing at the former Naturita plant is not currently used by area residents. As shown in Figure 2.8, ground water is not currently withdrawn within $2 \mathrm{mi}(3 \mathrm{~km})$ downgradient of the Naturita site. Area residents living downgradient of the Naturita site haul water for domestic purposes from the municipal water system in the town of Naturita which obtains water from the San Miguel River about $7 \mathrm{mi}(11 \mathrm{~km})$ upstream of the Naturita site. Shallow private wells situated on the properties downgradient of the Naturita site are inactive. However, the possibility exists for exposure via spring water on the private property downgradient of and adjacent to the Naturita site. The nearest active private domestic wells, which are completed in the alluvial aquifer are about 6400 and $6900 \mathrm{ft}(1900$ and $2000 \mathrm{~m})$ southeast (hydrologically upgradient) of the Naturita site (locations 2 and 3 in Figure 2.8). Therefore, these private wells are considered to be representative of background conditions.

Although plans for future land use do not specify residential developments at the Naturita site, such land uses cannot be precluded. Therefore, it is assumed that 


\begin{tabular}{cccc|c|c|c|} 
HISTORICAL & CURRENT & RELEASE & ENVIRONMENTAL \\
SOURCE & SOURCE & MECHANISM & $\begin{array}{c}\text { TRANSPORT } \\
\text { MEDIUM }\end{array}$ & $\begin{array}{c}\text { POSSIBLE } \\
\text { EXPOSURE } \\
\text { ROUTES }\end{array}$ & \multicolumn{2}{|c|}{ POTENTIAL RECEPTORS } \\
\cline { 3 - 6 } & FUTURE & $\begin{array}{c}\text { FERRESTRIAL } \\
\text { RELANTS AND } \\
\text { ANIMALSI } \\
\text { AIVESTOCK }\end{array}$ & $\begin{array}{c}\text { AQUATIC } \\
\text { PLANTS AND } \\
\text { ANIMALS }\end{array}$ \\
\hline
\end{tabular}
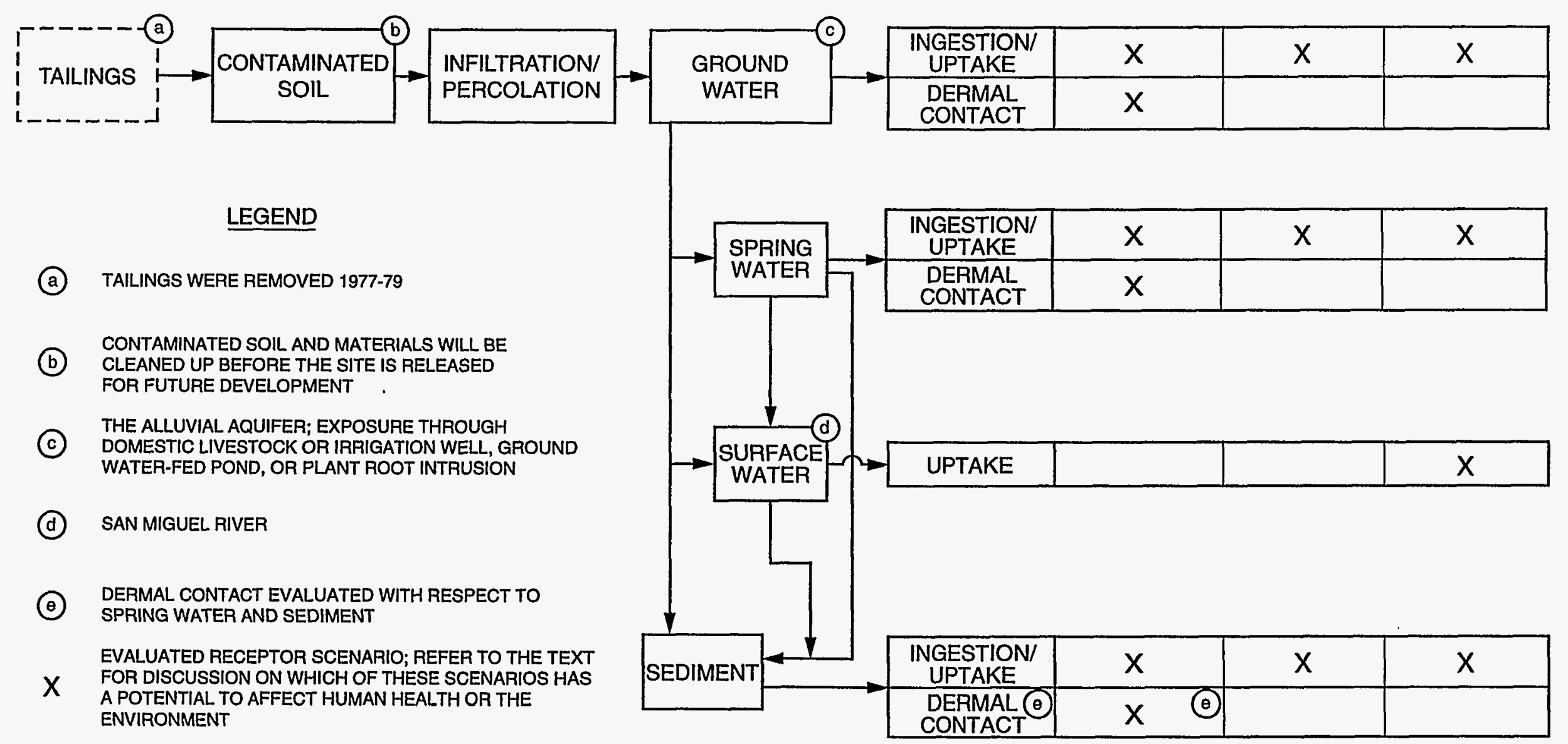

(a) TAILINGS WERE REMOVED 1977-79

CONTAMINATED SOIL AND MATERIALS WILL BE

CLEANED UP BEFORE THE SITE IS RELEASED FOR FUTURE DEVELOPMENT

(D) THE ALLUVIAL AQUIFER; EXPOSURE THROUGH

(c) DOMESTIC LIVESTOCK OR IRRIGATION WELL, GROUND WATER-FED POND, OR PLANT ROOT INTRUSION

(d) SAN MIGUEL RIVER

(e) DERMAL CONTACT EVAlUated WITH RESPECT TO SPRING WATER AND SEDIMENT

EVALUATED RECEPTOR SCENARIO; REFER TO THE TEXT

$X$ FOR DISCUSSION ON WHICH OF THESE SCENARIOS HAS A POTENTIAL TO AFFECT HUMAN HEALTH OR THE ENVIRONMENT

FIGURE 4.1

CONCEPTUAL MODEL NATURITA, COLORADO, SITE 
in the future, a private well could be installed in the most contaminated portion of the aquifer at the Naturita site creating the potential for exposure through drinking, bathing, livestock watering or irrigation. However, the likelihood of residential development in the future at the Naturita site is considered low. In addition, the residents living immediately downgradient of the Naturita site may use the ground water from the contaminated zone in the alluvial aquifer for watering livestock and a domestic garden in the future.

The hypothetical future resident scenario evaluates domestic ground water use consistent with current water uses by the population in the region. The potentially exposed population includes residents of the following age groups: infants (birth to 1 year old); children ( 1 to 10 years old), and adults (11 to 65 years old). These age groups were selected for the following reasons:

- Survey data for population variables such as age, weight, and daily water intake are available for these age groups.

- Toxicological variables are similar within these age groups, including responsiveness of sensitive subgroups (infants, children, and adults) to the contaminants of potential concern, toxicant intake-to-body-weight ratios, and toxicokinetics (a study of the time course of absorption, distribution, metabolism, and excretion of a contaminant in an individual's body).

The hypothetical direct exposure to contaminated spring water and its sediment associated with the drainage channel of the spring (the sediment) is evaluated for older children ( 9 to 10-years-olds), because they are likely to play on the floodplain and would receive higher exposures than adults. Secondary exposures, such as meat or milk ingestion from cattle grazed and watered on the floodplain near the spring, could occur in both children and adults.

Some individuals and /or subpopulations could be more vulnerable to possible exposures than the general population. These sensitive subpopulations could include infants, children, the elderly, or people with preexisting illness, such as diabetes or kidney insufficiency with the absence of diabetes.

\subsection{EXPOSURE PATHWAYS}

An exposure pathway describes the course a contaminant takes from the source to the exposed individual or population. Therefore, the exposure pathway can be completed only if there is a source of contamination, a point of contact with a population or individual, and the way a chemical enters the body after contact (e.g., water ingestion). The tailings pile was removed from the Naturita site and relocated to Coke Oven, Colorado. Although there are still about $250,000 \mathrm{yd}^{3}$ $\left(190,000 \mathrm{~m}^{3}\right)$ of contaminated soils at the Naturita site these contaminated soils and materials are being removed. They will be relocated to a disposal cell at the Uravan site, before the Naturita site is released for any future use. Also, access to the contaminated area has been restricted until the surface cleanup is completed. Therefore, soil or air exposure pathways (such as incidental soil 
ingestion, dermal contact with soil, or inhalation of particulates) are not considered.

This assessment evaluates both the ground water and the water and sediment pathways from the spring. Although recreational fishing is typical for the region and it could form an additional possible exposure pathway, the fish ingestion pathway is not considered because the Naturita site contamination impact to the river water quality is not measurable. Figures 4.1 and 4.2 provide a conceptual model of the possible and future ground water and the water and sediment from the spring exposure pathways that are believed to lead to the greatest exposure possible at the Naturita site. Pathways that are not considered in this model but could possibly be completed include exposure to soil contaminated via irrigation with contaminated ground water. These could include inhalation of fugitive dust and incidental soil ingestion. Preliminary calculations demonstrate that the sum of these pathways typically contributes much less to the total exposure dose than exposure from drinking water ingestion and would not be associated with health problems (DOE, 1995a). Under some future land uses or construction activities, these pathways could constitute a significant exposure. Upon determination of a specific land use or construction activity, these pathways might require additional evaluation.

\subsubsection{Ground water exposure pathways}

Although it is unlikely that the ground water in the alluvial aquifer at the Naturita site will be used in the future for drinking purposes because of the availability of a municipal water supply system in the town of Naturita, this risk assessment evaluates a hypothetical future use of the ground water from the alluvial aquifer.

In addition, the residents living immediately downgradient of the Naturita site may use the ground water from the alluvial aquifer for other beneficial uses in the hypothetical future.

Water in the region is used primarily for household purposes such as drinking, cooking, and bathing. Because the Naturita site is located in an agricultural zone (DOE, 1995a) and the water rights restrict the use of the San Miguel River water, other ground uses typical of the region, which could lead indirectly to human exposure, are crops irrigation or livestock watering.

\section{Drinking water ingestion}

Drinking water ingestion is generally the dominant exposure route for ground water contaminated with metals and other nonvolatile compounds (DOE, 1994a). In this evaluation, drinking water consumption includes amounts of water ingested by drinking and amounts of water used for food preparation (e.g., reconstituted juices, soup, rice, and beans). Because drinking water ingestion is typically the dominant pathway, it is the only pathway evaluated probabilistically in Section 4.4.1. 


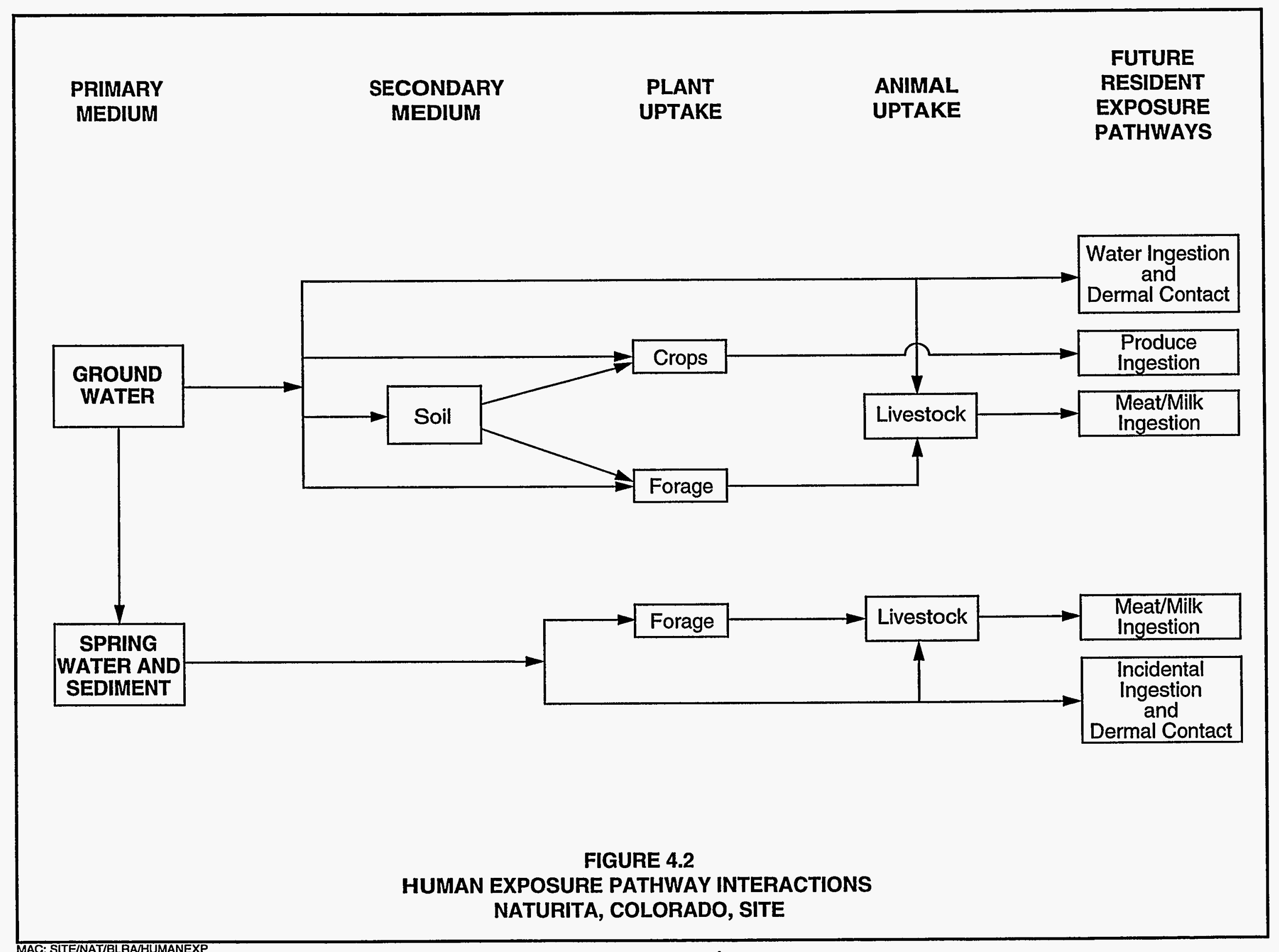




\section{Dermal absorption}

Dermal absorption is the process by which chemicals coming into contact with the skin become absorbed into the blood vessels near the skin surface. Although some compounds are absorbed easily in this manner, metals are generally poorly absorbed through intact skin (EPA, 1992a).

To determine if the dermal exposure route is important, a screening level calculation for the contaminants of potential concern was performed to compare dermal absorption to the exposure dose from ingesting water. Although the dermal dose is an absorbed dose, and only a percentage of the ingested dose will be absorbed, the very low ( 0.2 percent) relative contribution of dermal absorption is assumed to be insignificant compared to drinking water ingestion exposure route (DOE, 1995a). Because chemical-specific absorption factors are not available for these contaminants (metals are assumed to be absorbed like water); the assumptions used to estimate the dermal absorption exposure dose probably overestimate the potential exposure; and because the dose is less than a 1 percent incremental contribution to the exposure dose from drinking water ingestion, and would not be associated with health problems, this pathway is not further evaluated in this risk assessment.

\section{Produce ingestion}

Contaminants in ground water could be taken up by plants either through roots in soil saturated with contaminated ground water or from irrigation water obtained by a hypothetical well in the contaminated ground water. These plants could be eaten by humans or could enter the food chain and subsequently be consumed in the form of meat or milk, as discussed below. The amount this exposure route contributes could be substantial if the contaminants concentrate in plants; however, there are currently not enough data to evaluate this potential contribution based on literature values. The UMTRA Ground Water Project is currently studying contaminant uptake by irrigated vegetables and grasses. When these data become available, this pathway can be evaluated for this site; any results will be included in a site-specific National Environmental Policy Act (NEPA) document. If applicable, these data will also be considered in the development of a ground water compliance strategy for the Naturita site.

An evaluation of the potential damage to plants from contaminated ground water is presented in Section 7.0.

\section{Meat and milk ingestion}

Contaminants in ground water can enter the food chain when livestock or wildlife consume ground water that has reached the land surface or when animals consume plants that have taken up contaminants through roots tapping contaminated ground water. This exposure route is considered feasible because the Naturita site is located within an agricultural zone (DOE, 1995a). As with plant uptake, there are not sufficient data available in the literature to 
quantitatively evaluate this pathway for the contaminated ground water at the Naturita site. The results of the plant uptake studies and additional site characterization will enable this pathway to be better characterized. Any pertinent results will be included in a site-specific NEPA document and will be considered in the ground water compliance strategy, if applicable.

An evaluation of the direct toxicity of contaminants to livestock or wildlife is presented in Section 7.0.

\subsubsection{Floodplain exposure pathways}

This exposure scenario is considered because the spring waters are present on the residential portion of the San Miguel River floodplain downgradient of and adjacent to the Naturita site (538 in Figure 2.8). This spring may form possible indirect pathways to humans via the consumption of meat or milk from livestock grazed and watered at or near the spring (538 in Figure 2.8) on the floodplain. Although cattle are not currently kept on this property, the meat or milk ingestion pathways may be completed in the future because the property is within an agriculture zone where cattle grazing occurs. In the future, cattle may consume both the spring water and vegetation that become contaminated through the uptake of contaminants from shallow ground water. Incidental access to the spring by residents (children or adults) and subsequent direct contact with surface water body contaminated by spring waters may create another possible human exposure pathway. Contaminants of potential concern detected in the spring water, sediment, and vegetation associated with the spring (538 in Figure 2.8) are selected for a detailed evaluation of these pathways in Section 4.4.2.

\subsection{EXPOSURE CONCENTRATIONS}

Exposure concentration of a contaminant in a medium is that concentration contacted by an individual over the period of exposure being considered.

\subsubsection{Ground water}

In this evaluation, it is assumed that the contaminant concentrations and exposures will remain at current levels, even though actual exposure concentrations are expected to decrease with time because the tailings have been removed and the contaminated soils at the Naturita site will be cleaned up. Nonetheless, current levels are reasonable for chronic exposure soon after surface remediation. Chronic exposure for noncarcinogens is considered to be any period longer than 7 years. For carcinogens, a lifetime exposure over 50 years is considered.

To evaluate potential toxicity of noncarcinogens from human ingestion of ground water, exposure concentrations are described as a probability of occurrence based on ground water data collected from alluvial monitor wells 616 and 632 . Alluvial monitor wells 616 and 632 were in the former tailings pile area and with 
one exception, they consistently showed the highest contamination levels through 4 years of monitoring from 1989 to 1992 (the 600 series wells were removed or destroyed in late 1992). Manganese levels were consistently higher in alluvial monitor well 656 than in alluvial monitor wells 616 and 632 . Therefore, the analysis of manganese toxicity is conducted based on concentrations observed in ground water from alluvial monitor well 656.

For each contaminant of potential concern, a probability distribution was selected as a model of the random variation in water quality currently accessible by the most contaminated alluvial monitor wells on the Naturita site (DOE, 1995a). Concentrations of most contaminants have been stable for the last five years (not trending upward or downward), and the selected probability distribution had the same mean and standard deviation and approximately the same shapes as occurred in the actual data. A subset of constituents (molybdenum, uranium, and vanadium) showed statistically significant trends in concentration since 1989. For these constituents, the probability distribution was shifted to reflect the more recently acquired data on concentration levels. The tails of the distributions were truncated in an attempt to place a reasonable upper limit on potential future exposures below $0.0 \mathrm{mg} / \mathrm{L}$ and above the 99th percentile. The probability associated with the disallowed portion was assigned proportionally to the allowable values, so that the total probability under the truncated curve remained equal to 1.0. Specifications for the probability distributions for contaminant concentrations are shown in Table 4.1.

To estimate carcinogenic risks, point estimates of exposure are used. The upper 95 percent confidence interval estimate for the mean of the concentration is used for uranium-234/-238, radium-226, and radium-228 activities, and for the mean arsenic concentration. Maximum observed activities are used to evaluate lead-210, polonium-210, and thorium-230 carcinogenicity. This is because only two rounds of ground water sampling data are available for these constituents. Carcinogenic effects associated with exposure to uranium-234/-238, radium-226, radium-228, lead-210, polonium-210, thorium-230 and arsenic are evaluated in Section 6.0.

\subsubsection{Spring water, associated sediment, and plants}

Spring water and sediment pathways are of interest because of incidental human ingestion. Plant uptake and food chain transfer may also occur under current conditions near the Naturita site (i.e., from the steadily flowing spring on the property downgradient of and adjacent to the Naturita site).

For the human exposure pathways associated with incidental ingestion of the spring water and sediment, incidental dermal contact with the spring water and sediment, and ingestion of meat and milk from livestock grazed and watered on the San Miguel River floodplain, observed contaminant concentrations in the spring water, sediment, and adjacent plants are used (Table 4.2). 
Table 4.1 Concentration probability distributions for the chemical contaminants of potential concern in the alluvial aquifer, Naturita, Colorado, site

\begin{tabular}{llccc}
\hline $\begin{array}{c}\text { Contaminant of } \\
\text { potential concern }\end{array}$ & \multicolumn{1}{c}{$\begin{array}{c}\text { Type of } \\
\text { distribution }\end{array}$} & $\begin{array}{c}\text { Mean value } \\
(\mathrm{mg} / \mathrm{L})\end{array}$ & $\begin{array}{c}\text { Standard } \\
\text { deviation } \\
(\mathrm{mg} / \mathrm{L})\end{array}$ & $\begin{array}{c}\text { Maximum } \\
\text { allowed value } \\
\text { (mg/L) }\end{array}$ \\
\hline Antimony & Lognormal & 0.008 & 0.012 & 0.055 \\
Arsenic & Exponential & 0.032 & 0.0 & 0.15 \\
Manganese & Normal & 4.9 & 1.9 & 9.2 \\
Molybdenum & Normal & 0.28 & 0.03 & 0.35 \\
Selenium & Lognormal & 0.022 & 0.023 & 0.11 \\
Sodium & Lognormal & 972 & 103 & 1237 \\
Sulfate & Normal & 1208 & 144 & 1542 \\
Uranium & Normal & 1.8 & 0.7 & 3.4 \\
Vanadium & Normal & 10 & 2 & 15 \\
\hline
\end{tabular}

mg/L - milligrams per liter. 
Table 4.2 Exposure concentration for the spring water, sediment, and plants (November 1994 sampling round), Naturita, Colorado, site

\begin{tabular}{|c|c|c|c|}
\hline $\begin{array}{l}\text { Contaminant of } \\
\text { potential concern }\end{array}$ & $\begin{array}{c}\text { Spring water } \\
\text { concentration" } \\
\text { (Cw) } \\
\text { (mg/L) }\end{array}$ & $\begin{array}{l}\text { Spring sediment } \\
\text { concentration } \\
\text { (Cs) } \\
\text { (mg/kg) }\end{array}$ & $\begin{array}{c}\text { Plant concentration } \\
\text { (Cp) } \\
(\mathbf{m g} / \mathbf{k g})\end{array}$ \\
\hline Antimony & $<0.003$ & 1 & 1.7 \\
\hline Arsenic & $<0.005$ & 13 & 49 \\
\hline Manganese & 0.98 & 610 & 2250 \\
\hline Molybdenum & $<0.01$ & 1 & $<5$ \\
\hline Sulfate & 391 & 93 & NA \\
\hline Uranium & 0.11 & 19 & 22 \\
\hline Vanadium & $<0.01$ & 24 & 55 \\
\hline $\begin{array}{l}{ }^{a} \text { Unfiltered water sa } \\
\text { mg/L - milligrams } p \\
\text { mg/kg - milligrams } \\
\mathrm{NA} \mathrm{-} \mathrm{not} \mathrm{available.} \\
\mathrm{CW} \text { - Contaminant } \\
\mathrm{Cs} \text { - Contaminant } \\
\mathrm{Cp} \text { - Contaminant }\end{array}$ & $\begin{array}{l}\text { s. } \\
\text { ilogram. } \\
\text { ntration in surf } \\
\text { ntration in sedim }\end{array}$ & $\begin{array}{l}\text { ter body (milligra } \\
\text { illigrams per kilc } \\
\text { grams per kilogra }\end{array}$ & $\begin{array}{l}\text { per liter). } \\
\text { m). }\end{array}$ \\
\hline
\end{tabular}




\subsection{ESTIMATION OF INTAKE}

\subsubsection{Ground water ingestion pathway}

Individuals within the population of future residents are anticipated to vary with respect to water consumption habits, stable body weight, and length of residence in the potential contamination zone. Consequently, health risks associated with ground water consumption will also vary among members of the population. To adequately describe the range of potential risks to the future population, naturally occurring variability in daily water intake, body weight and residency time were incorporated in this assessment, where possible, through probability distributions selected from published public health and census documents for the United States. All distributions were truncated at the upper and lower 0.01 percentile (DOE, 1995a). Values disallowed through this truncation have a probability of less than 1 in 10,000 of occurring within the hypothetical population.

The potential toxicity of noncarcinogenic contaminants in drinking water and potential carcinogenicity of arsenic depend primarily on long-term average daily consumption of the contaminant per kilogram of body weight (measured in milligrams per kilogram per day [mg/kg-day]). "Long-term" or "chronic" is defined as at least 7 years for noncarcinogens and 50 years for arsenic carcinogenicity. For noncarcinogens, chronic daily intake is calculated as follows:

\begin{tabular}{|c|c|c|c|c|}
\hline \multirow{3}{*}{$\begin{array}{l}\text { Intake } \\
(\mathrm{mg} / \mathrm{kg} \text {-day })=\end{array}$} & & Ingestion & \multirow{2}{*}{$\begin{array}{l}\text { Exposure } \\
\text { frequency } \\
\text { (days/year) }\end{array}$} & \multirow{2}{*}{$\begin{array}{c}\text { Exposure } \\
\times \text { duration } \\
\text { (vears) }\end{array}$} \\
\hline & $\begin{array}{c}\text { Concentration } \\
(\mathrm{mg} / \mathrm{L})\end{array}$ & $\begin{array}{c}\text { rate } \\
\text { (L/day) }\end{array}$ & & \\
\hline & & $\begin{array}{l}\text { weight } x \\
\mathrm{~kg} \text { ) }\end{array}$ & $\begin{array}{l}\text { Averaging } \\
65 \text { days } \times \text { ED }\end{array}$ & $\begin{array}{l}\text { ne } \\
\text { years]) }\end{array}$ \\
\hline
\end{tabular}

Potential carcinogenicity of arsenic increases with total intake over a lifetime. Therefore, arsenic exposure is estimated as a daily intake of the contaminant per kilogram of body weight averaged over the 70-year life span exposure duration and is measured in $\mathrm{mg} / \mathrm{kg}$-day. Thus, for arsenic as a carcinogen, the daily intake is calculated as follows:

(2)

\begin{tabular}{|c|c|c|c|c|c|}
\hline \multirow[b]{2}{*}{$\begin{array}{l}\text { Intake } \\
(\mathrm{mg} / \mathrm{kg}-\text { day })=\end{array}$} & & \multicolumn{2}{|r|}{ Ingestion } & \multirow{2}{*}{$\begin{array}{l}\text { Exposure } \\
\text { frequency } \\
\text { (days/year) }\end{array}$} & \multirow{2}{*}{$\begin{array}{l}\text { Exposure } \\
\times \text { duration } \\
\text { (vears) }\end{array}$} \\
\hline & $\begin{array}{c}\text { Concentration } \\
(\mathrm{mg} / \mathrm{L})\end{array}$ & $x$ & $\begin{array}{c}\text { rate } \\
\text { (L/day) }\end{array}$ & & \\
\hline
\end{tabular}

The potential carcinogenicity of radionuclides is thought to increase with total intake over time, instead of with average daily intake as for noncarcinogens. Also, body weight is relatively insignificant in determining risk from exposure. 
Intake of radionuclides (measured in $\mathrm{pCi}$ ) is therefore quantified as total exposure to radioactivity through the residency period of an individual:

(3) $\begin{aligned} & \text { Intake } \\ & (\mathrm{pCi} / \text { lifetime })=\underset{(\mathrm{pCi} / \mathrm{L})}{\text { Concentration }} \times \underset{(\mathrm{L} / \text { day })}{\text { rate }}\end{aligned} \times \begin{gathered}\text { Exposure } \\ \text { (days/year) }\end{gathered} \times \begin{gathered}\text { Exposure } \\ \text { (dears) }\end{gathered}$

Average daily intake (L/day)

Lognormal probability distributions were used to describe variations in average daily tap water intake among members of the population (Roseberry and Burmaster, 1992). These distributions were developed from data collected during a 1977-78 food consumption survey conducted by the U.S. Department of Agriculture. During the survey, total tap water consumption during a 3-day period was recorded for 26,081 survey participants nationwide (Figure 4.3).

\section{Body weight $(\mathrm{kg})$}

Extensive national data on weights of males and females, by age, were collected during a health and nutrition survey conducted from 1976 to 1980 . These data were used to develop lognormal probability distributions for body weight by age and separately by gender. The distributions for males and females were then combined using census data on the national ratio of males and females within each age group (Figure 4.4).

\section{Exposure frequency (days/vear)}

Individuals generally are not present at their homes and are not drinking water from the same source for $\mathbf{3 6 5}$ days per year. Individuals vary in their travel and vacation habits, but it could not be assumed that residents of Naturita, Colorado would follow national norms in this respect. Therefore, calculation of intake incorporated a fairly narrow range of possible exposure frequencies from a minimum of 300 to a maximum of 365 days per year. The most common exposure was assumed to be $\mathbf{3 5 0}$ days per year, which allows for a two week absence from home. The probability distribution for exposure frequency was selected to be triangular, because no actual site data were available to support the choice of a more complicated shape.

\section{Exposure duration (vears)}

For noncarcinogenic effects, the exposure duration in the numerator and denominator of the drinking water intake equations (see equation (1)) cancels out, assuming all exposures are chronic (i.e., at least 7 years). Thus, deviations from the standard residence time assumptions do not affect the results. However, for carcinogenic effects of arsenic, uranium, and other radionuclides, risk is cumulative throughout a lifetime; therefore, deviations from the hypothesized residency distribution could considerably affect the risk estimate. 

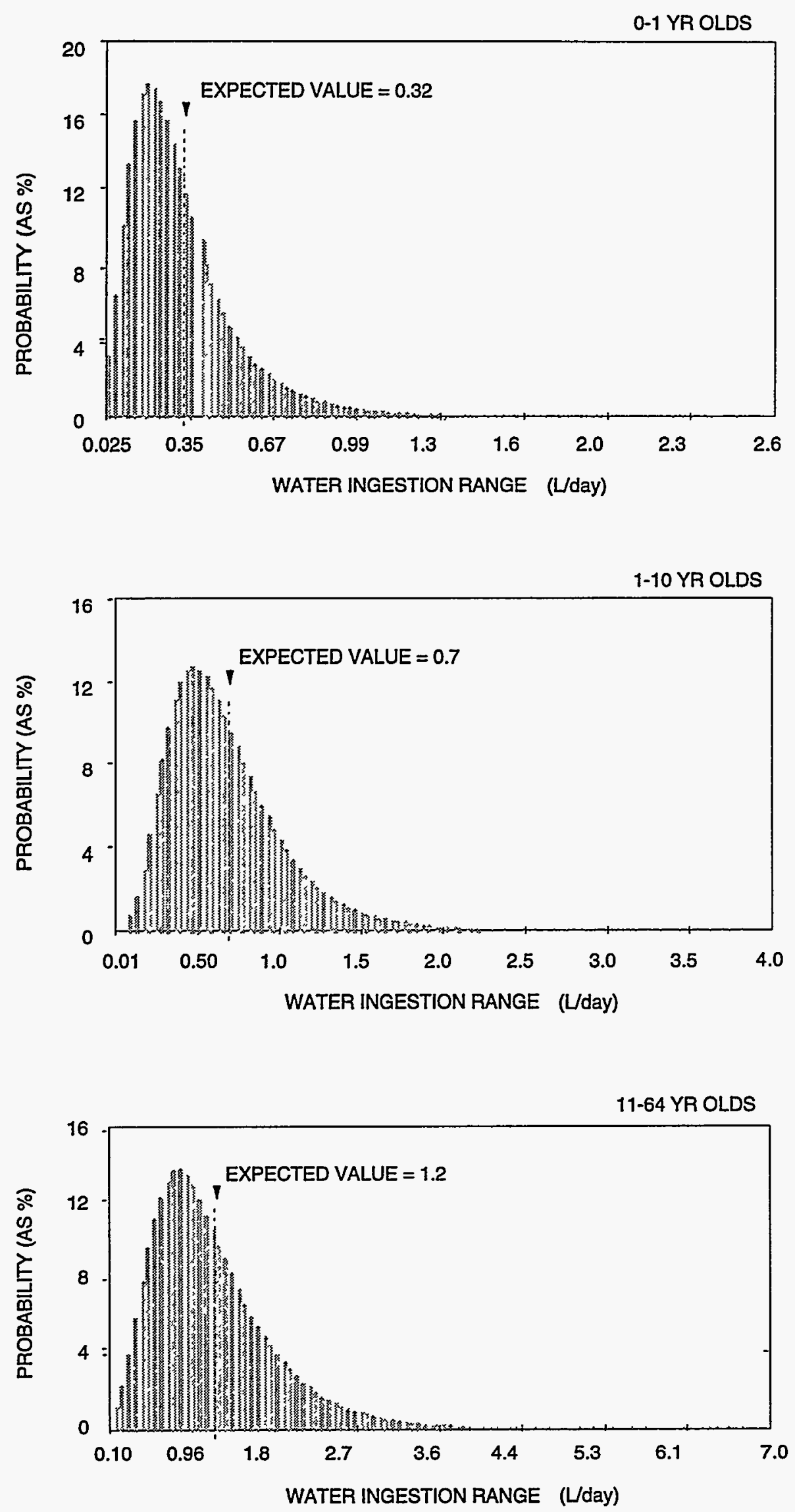

FIGURE 4.3

PROBABILITY DISTRIBUTIONS FOR TAP WATER INGESTION RATES 

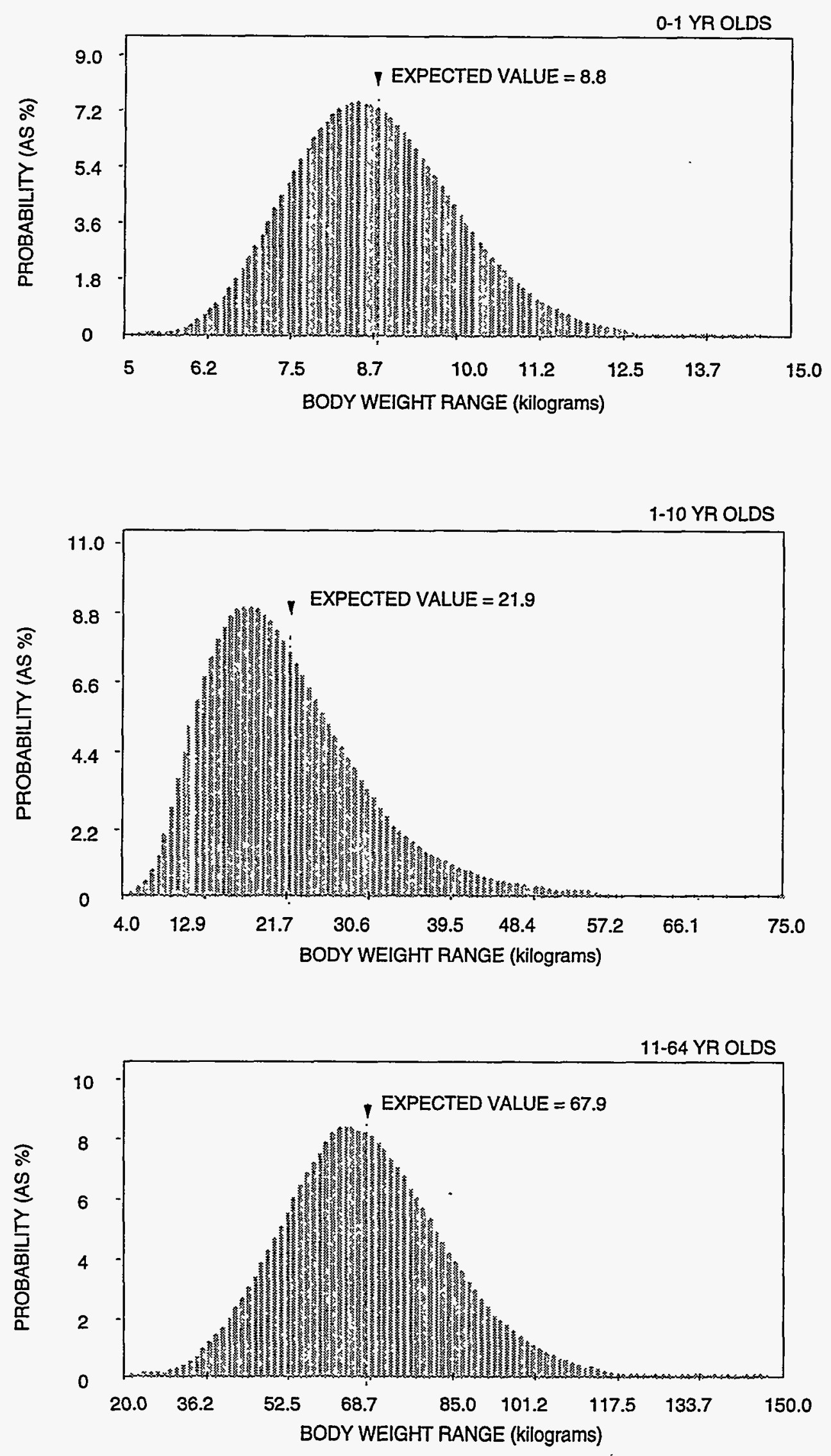

FIGURE 4.4 PROBABILITY DISTRIBUTIONS FOR BODY WEIGHT 
Because the Naturita site area is located within an agricultural zone where very low mobility would be expected, a fixed lifetime exposure of 50 years, assumed for Naturita residents, is used to estimate lifetime cancer risks.

Using exposure concentration distributions discussed in Section 4.3.1 and the intake parameter distribution from this section, total intake distributions were simulated for the three age groups 10- to 1-, 1- to 10-, and 11- to 65-year-olds) using the @RISK software package (Palisade Corporation, 1992) and 10,000 iterations (DOE, 1995a). The 1-to 10-year-old group consistently showed the highest intake-to-body-weight ratio (Table 4.3) and therefore is the most conservative age group to evaluate. This age group is likely more susceptible to metal toxicity than adults, because of higher gastrointestinal absorption efficiency and other toxicokinetic factors (Casarett and Doull, 1991). However, because infants are the most sensitive group for sulfate toxicity, the intake distributions for this age group (i.e., age 0 to 1 year) are used for this contaminant. Simulated intake distributions for appropriate age groups for contaminants of potential concern evaluated probabilistically are generally asymmetric, being skewed toward high values. Table 4.3 summarizes basic characteristic of the intake distributions for chemical contaminants of potential concern. The intake estimates used to calculate carcinogenic risk are presented in Section 6.2.

\subsubsection{Floodplain exposure pathways}

To describe the potential risk for the future population, daily water intake, body weight, and other pertinent variables are incorporated into this assessment using the default values, according to the standard EPA procedure (EPA, 1989a).

The pathways that may occur in the future on the floodplain include incidental ingestion of the spring water and sediment, dermal contact with the spring water and sediment while wading, and consumption of contaminated meat and milk from livestock grazed and watered at or near the spring identified on the floodplain.

For this evaluation, it is assumed that incidental ingestion of water and sediment from the spring, as well as dermal contact with water and sediment, would most likely occur during summer. Older children (about 9-10 years olds) are considered the subpopulation most likely to play on the floodplain.

\section{Incidental ingestion of spring water and associated sediment}

Incidental ingestion of the spring water and sediment ingestion could occur when children play on the floodplain. During this play, it is assumed that children may incidentally ingest a few tablespoons of water and about $100 \mathrm{mg}$ of sediment. It is further assumed that children would visit the spring area every day during the summer as well as visiting it on weekends during three other months of the year. Table 4.4 summarizes the results of possible human intake of contaminants of potential concern through incidental ingestion of the 
Table 4.3 Intake probability distributions for the chemical contaminants of potential concern in the alluvial aquifer, Naturita, Colorado, site

\begin{tabular}{|c|c|c|c|c|c|c|c|}
\hline \multirow{2}{*}{$\begin{array}{c}\text { Contaminant } \\
\text { of potential } \\
\text { concern }\end{array}$} & \multirow{2}{*}{$\begin{array}{c}\text { Age } \\
\text { group } \\
\text { (years) }\end{array}$} & $\begin{array}{c}\text { Minimum } \\
\text { value }\end{array}$ & $\begin{array}{l}\text { Mean } \\
\text { value }\end{array}$ & $\begin{array}{c}\text { Median } \\
\text { value }\end{array}$ & $\begin{array}{l}\text { Standard } \\
\text { deviation }\end{array}$ & $\begin{array}{c}\text { Maximum } \\
\text { value }\end{array}$ & $\begin{array}{c}\text { 99th } \\
\text { percentile }\end{array}$ \\
\hline & & \multicolumn{6}{|c|}{ (mg/kg-day) } \\
\hline Antimony & $1-10$ & $1 \mathrm{E}-06$ & $3 E-04$ & $1 \mathrm{E}-04$ & $4 \mathrm{E}-04$ & $9 E-03$ & $2 E-03$ \\
\hline Arsenic & $1-10$ & $1 \mathrm{E}-08$ & $1 E-03$ & $6 \mathrm{E}-04$ & $1 E-03$ & $2 E-02$ & 7E-03 \\
\hline Manganese & $1-10$ & 0 & 1.7E-01 & $1.3 \mathrm{E}-01$ & 1.4E-01 & $2.5 E+00$ & 7E-01 \\
\hline Molybdenum & $1-10$ & $6 \mathrm{E}-04$ & 1E-02 & $8 E-03$ & 7E-03 & $9 E-02$ & $4 E-02$ \\
\hline Selenium & $1-10$ & $5 E-06$ & 7E-04 & $4 \mathrm{E}-04$ & 9E-04 & $1.8 \mathrm{E}-02$ & $4.5 \mathrm{E}-03$ \\
\hline Sodium & $1-10$ & $2 E+00$ & $33 E+00$ & $27 E+00$ & $24 E+00$ & $42 E+01$ & $12.3 E+01$ \\
\hline \multirow[t]{3}{*}{ Sulfate } & $0-1$ & $3 E+00$ & $41 E+00$ & $34 E+00$ & $30 E+00$ & $34 E+01$ & $15.6 E+01$ \\
\hline & $1-10$ & $3 E+00$ & $42 E+00$ & $34 E+00$ & $30 E+00$ & $39 E+01$ & $15.2 E+01$ \\
\hline & $11-65$ & $2 E+00$ & $21 E+00$ & $18 E+00$ & $13 E+00$ & $15 E+01$ & $65.5 E+00$ \\
\hline Uranium & $1-10$ & 0 & $6 \mathrm{E}-02$ & $5 E-02$ & $5 E-02$ & 7.6E-01 & $2.5 \mathrm{E}-01$ \\
\hline Vanadium & $1-10$ & $1.6 \mathrm{E}-02$ & 3.4E-01 & 2.8E-01 & 2.6E-01 & $3.8 E+00$ & $1.3 E+00$ \\
\hline
\end{tabular}


Table 4.4 Exposure dose calculations and equation definitions for the hypothetical, incidental ingestion of spring water and sediment by children on the floodplain, Naturita, Colorado, site

\begin{tabular}{lllllll}
\hline & & \multicolumn{5}{c}{$\begin{array}{c}\text { Exposure dose from } \\
\text { ingestion of }\end{array}$} \\
\cline { 5 - 6 } $\begin{array}{c}\text { Contaminant of } \\
\text { potential concern }\end{array}$ & $\begin{array}{c}\text { Cw } \\
\text { (mg/L) }\end{array}$ & $\begin{array}{c}\text { Cs } \\
\text { (mg/kg) }\end{array}$ & $\begin{array}{c}\text { WATER } \\
\text { (mg/kg- day) }\end{array}$ & $\begin{array}{c}\text { SEDIMENT } \\
\text { (mg/kg-day) }\end{array}$ & $\begin{array}{r}\text { Total exposure dose } \\
\text { (mg/kg-day) }\end{array}$ \\
\hline Antimony & ND & 1 & NA & $8 E-07$ & $8 E-07$ \\
Arsenic & ND & 13 & NA & $1 E-05$ & $1 E-05$ \\
Manganese & 0.98 & 610 & 4E-04 & $5 E-04$ & $9 E-04$ \\
Molybdenum & ND & 1 & NA & $8 E-07$ & $8 E-07$ \\
Sulfate & 391 & 93 & $2 E-01$ & $7 E-05$ & $2 E-01$ \\
Uranium & 0.11 & 19 & 4E-05 & $2 E-05$ & $6 E-05$ \\
Vanadium & ND & 24 & NA & $2 E-05$ & $2 E-05$ \\
\hline
\end{tabular}

Equation definitions for exposure dose calculations

Intake from incidental ingestion of surface water is calculated as follows:

Chemicals: $\quad$ Chronic daily intake $\left(\mathrm{mg} / \mathrm{kg}\right.$-day) $=\frac{\mathrm{CW} \times \operatorname{IRW} \times \mathrm{EF} \times \mathrm{ED}}{\mathrm{BW} \times \mathrm{AT}}$

Radionuclides: Lifetime intake ( $\mathrm{pCi} / \mathrm{lifetime)}=\mathrm{Cw} \times \mathrm{IRw} \times \mathrm{EF} \times \mathrm{ED}$

Intake from incidental ingestion of sediment is calculated as follows:

Chemicals: $\quad$ Chronic daily intake $(\mathrm{mg} / \mathrm{kg}$-day) $=\mathrm{Cd} \times \mathrm{Csf} \times \mathrm{Rs} \times \mathrm{F}(\times \mathrm{EF} \times \mathrm{ED}$

BW $\times A T$

Radionuclides: Lifetime intake ( $\mathrm{pCi} /$ lifetime) $=\mathrm{Cs} \times \mathrm{Csf} \times \mathrm{IRs} \times \mathrm{FI} \times \mathrm{EF} \times \mathrm{ED}$

Where:

$\mathrm{Cw}=$ Contaminant concentration in spring water (for location 538).

Irw = Ingestion rate for water $(0.05 \mathrm{~L} /$ day for older children).

$\mathrm{EF}=$ Exposure frequency (events/year) $(3$ months per year during 7 events per week $=84$ events, and 3 months per year during weekends = 24 events; total incidental exposure frequency equals 108 events per year).

$E D=$ Exposure duration (7 years for older children playing in the spring area).

BW $=$ Body weight $138.3 \mathrm{~kg}$ for older children; 90 th percentile body weight for 9- to 10-year old male child, EPA, 1989a).

$A T=$ Averaging time ( 365 days $\times$ ED for noncarcinogens; 365 days $\times 70$ years for carcinogens)

Cs = Contaminant concentration in sediment (for location 538).

Csf = Conversion factor $\left(10^{-6} \mathrm{~kg} / \mathrm{mg}\right)$ (EPA, 1989a).

$\mathrm{FI}=$ Fraction ingested from sediment (1.0; unitless)

Irs $=$ Ingestion rate for sediment (100 mg/day) (EPA, 1989a).

$C_{w}$ - contaminant concentration in surface water.

Cs - contaminant concentration in sediment water.

ND - not detected.

NA - not applicable.

$\mathrm{mg} / \mathrm{kg}$-day - milligrams per kilogram per day. 
spring water and sediment. These human exposure pathways are further evaluated in Section 6.0.

\section{Dermal contact with spring water and sediment}

For the same scenario presented above, it is assumed that children's arms and legs will come into contact with the spring water and sediment. These lead to the potential exposure route from dermal absorption, although metals are generally poorly absorbed through the intact skin.

To determine whether dermal exposure route is likely to be a significant route of exposure, screening level calculations were performed to learn what is the relative contribution of dermal absorption as compared to exposure doses from the incidental ingestion of surface water and sediment for the contaminants of potential concern detected in these media (DOE, 1995a). Because chemicalspecific absorption factors from water are not available for these contaminants, they are assumed to absorbed across intact skin at the same rate as water. This assumption probably overestimates the potential exposure contribution from dermal absorption of contaminants from surface water. Also, because literature information is limited on chemical-specific absorption factors from sediment, the upper end of the absorption factor developed for cadmium is used (EPA, 1992a). Cadmium is the only inorganic chemical known to have the skin absorption factor from soil developed experimentally (EPA, 1992a).

Although dermal dose is an absorbed dose, and only a percentage of the ingested dose will be absorbed, the low relative contribution (1 percent for both water and sediment) of dermal absorption from the water and sediment is low compared to incidental ingestion of surface water and sediment exposure routes (DOE, 1995a). Therefore, these pathways are not further evaluated in this risk assessment.

\section{Ingestion of meat and milk}

Although cattle is not currently kept at the private property where the surface expression of ground water exists, these human exposure pathways are considered because the Naturita site area is located within an agricultural zone where cattle grazing occurs. Therefore, these human exposure pathways may possibly be completed in the future.

The floodplain area affected by the spring is very limited. Therefore, it is conservatively assumed that future cattle grazing on the floodplain could obtain about half of the amount of water drunk daily, about 0.2 percent of the total daily amount of ingested sediment and 0.3 percent of the pasture, at or near the spring. It is further assumed that the residents could consume all of their meat and milk from these cattle. These assumptions, however, are likely to overestimate potential future human exposure from these pathways. 
Manganese, uranium, antimony, arsenic, and vanadium are the contaminants of potential concern evaluated quantitatively. Because no data were collected on sulfate concentration in plants growing at the spring location, sulfate intake from drinking the milk and eating the meat from cattle grazing near the spring could not be evaluated quantitatively. The results of this evaluation are summarized in Table 4.5. These human exposure pathways are further evaluated in Section 6.0.

\subsection{EXPOSURE ASSESSMENT UNCERTAINTIES}

Several potential sources of error may arise in all phases of an exposure assessment. Some meaningful sources of uncertainty are listed below.

- Uncertainties resulting from the lack of thorough environmental characterization of the Naturita site. This uncertainty could lead to an underestimate or overestimate in the exposure analysis.

- Uncertainties associated with the lack of seasonal characteristics of ground water/surface water interaction which could result in an underestimate or overestimate in the exposure assessment.

- Uncertainties arising from the use of filtered versus unfiltered ground water samples. The results of the exposure assessment presented in this document are primarily based on filtered $(0.45$-micrometer $[\mu \mathrm{m}])$ ground water samples. Therefore, the potential loss of certain ground water constituents as a results of filtration is associated with an additional source of uncertainty.

- Uncertainties arising from the assumption that the ground water contaminant source term at the Naturita site has reached a steady state and that contaminant concentrations at the exposure point will remain constant for chronic periods of exposure (generally greater than 7 years). This assumption likely overestimates true future exposures as contaminant concentrations decline after removal of the source term.

- Uncertainties associated with the additivity of exposures from other pathways. Although the drinking water ingestion pathway is considered the major determinant of exposure in this risk assessment, the incremental contribution from the ground water-irrigated produce-ingestion and/or meat and milk ingestion pathways (which could not be estimated here) should be considered.

- Uncertainties associated with estimating the amount of contaminant absorbed through the skin.

- Uncertainties associated with differing sensitivities of subpopulations, such as diabetics, children, and the elderly. 
Table 4.5 Exposure dose calculations and equation definitions for future hypothetical adult meat and milk consumption from cattle grazed and watered on the floodplain area, Naturita, Colorado, sịte

\begin{tabular}{|c|c|c|c|c|c|c|c|c|}
\hline \multirow{2}{*}{$\begin{array}{l}\text { Contaminant } \\
\text { of potential } \\
\text { concem }\end{array}$} & \multirow{2}{*}{$\begin{array}{c}\text { Cw } \\
\text { (mg/L }\end{array}$} & \multirow{2}{*}{$\begin{array}{c}\text { Cs } \\
\text { (mg/kgl }\end{array}$} & \multirow{2}{*}{$\begin{array}{c}\mathrm{Cp} \\
(\mathrm{mg} / \mathrm{kg}) \\
\end{array}$} & \multicolumn{2}{|c|}{$\begin{array}{c}\text { Transfer } \\
\text { coefficients }\end{array}$} & \multicolumn{2}{|c|}{$\begin{array}{l}\text { Exposure dose } \\
\text { (mg/kg-day) }\end{array}$} & \multirow{2}{*}{$\begin{array}{c}\text { Total } \\
\text { intake } \\
\text { (mg/kg-day) }\end{array}$} \\
\hline & & & & $\mathbf{F b}$ & Fm & Beef & Milk & \\
\hline Antimony & $<0.003$ & 1.0 & 1.7 & 0.001 & 0.0001 & 7E-08 & $3 E-08$ & $1 \mathrm{E}-07$ \\
\hline Arsenic & $<0.0005$ & 13.0 & 49.0 & 0.002 & 0.00006 & $4 E-06$ & $5 E-07$ & $5 E-06$ \\
\hline Manganese & 0.98 & 610 & 2250 & 0.0004 & 0.00035 & $4 E-05$ & $2 E-04$ & $2 E-04$ \\
\hline Uranium & 0.11 & 19.0 & 22.0 & 0.0002 & 0.0006 & $7 E-07$ & $8 E-06$ & $9 E-06$ \\
\hline
\end{tabular}

Equation definitions for exposure dose calculations

Intake from consumption of contaminated meat from cattle grazed on pasture grasses irrigated with contaminated water and watered with contaminated water is calculated as follows:

Chemicals: Chronic daily intake (mg/kg-day) $=\frac{\mathrm{Cb} \times \mathrm{IRb} \times \mathrm{FI} \times \mathrm{EF} \times \mathrm{ED}}{\mathrm{B}}$

$B W \times A T$

and

$\mathrm{Cb}=\mathrm{Fb}[(\mathrm{Cp} \times \mathrm{Op})+(\mathrm{Os} \times \mathrm{Cs})+(\mathrm{Ow} \times \mathrm{Cw})]$

Intake from consumption of contaminated meat from cattle grazed on pasture grasses irrigated with contaminated water and watered with contaminated water is calculated as follows:

Chemicals: Chronic daily intake (mg/kg-day) $=\underline{\mathrm{Cm} \times \operatorname{Rm} \times \mathrm{F} \mid \times E F \times E D}$

$$
B W \times A T
$$

and

$C m=F m[(C p \times Q p)+(C s \times Q s)+(C w \times Q w)]$

Where:

$\mathrm{Cb}=$ Contaminant concentration in beef (calculated value; chemical-specific; milligrams per kilogram).

$\mathrm{Cm}$ = Contaminant concentration in milk (calculated value; chemical-specific; milligrams per kilogram).

Irb = Ingestion rate for homegrown beef $(0.075 \mathrm{~kg} /$ day) (EPA, 1989a).

$\mathrm{IRm}=$ Ingestion rate for milk $(0.03 \mathrm{~kg} /$ day, EPA, 1989a).

FI Fraction of diet ingested $(0.75$, unitless; subsistence farm family).

$\mathrm{EF}=$ Exposure frequency ( 350 days/year).

$E D=$ Exposure duration (7 years).

$B W=$ Body weight $(70 \mathrm{~kg}$ for an adult $)$.

$A T=$ Averaging time $(365$ days $\times \mathrm{ED})$

$\mathrm{Fb}=$ Forage-to-beef transfer coefficient (chemical-specific; unitless) (Baes et al., 1984).

$\mathrm{Fm}=$ Feed-to-milk transfer coefficient (chemical-specific; unitless; Baes et al., 1984).

$C_{p}=$ Contaminant concentration in plants milligrams per kilogram. 
Table 4.5 Exposure dose calculations and equation definitions for future hypothetical adult meat and milk consumption from cattle grazed and watered on the floodplain area, Naturita, Colorado, site (Concluded)

Qp = quantity of pasture ingested daily by cattle $10.05 \mathrm{~kg}$ dry weight per day; assumption: 0.3 percent of the total amount of pasture ingested daily; this amount is $19 \mathrm{~kg}$ dry weight per day (EPA, 1989a).

Qs = Quantity of soil ingested daily by cattle $10.0008 \mathrm{~kg}$; assumption: 0.2 percent of the total amount of soil ingested daily; this amount is $0.38 \mathrm{~kg}$ based on 2 percent of dry matter from feed ingestion rate; EPA, 1989a).

Cs = Contaminant concentration in sediment (milligrams per kilogram).

$\mathrm{OW}_{\mathrm{w}}=$ Quality of water ingested daily by cattle $(28 \mathrm{~L} / \mathrm{day}$; assumption: half of the amount of water drunk daily; this amount is $56 \mathrm{~L}$ /day; EPA, 1989a).

$\mathrm{Cw}=$ Contaminant concentration in surface water body (milligrams per liter). 
Despite these uncertainties, the use of probability distributions that incorporate all definable sources of variability should provide a representative picture of the potential range of exposures from the drinking water ingestion pathway. 


\subsection{TOXICITY ASSESSMENT}

A number of contaminants that have the potential for causing adverse human health and environmental effects have been detected in ground water at the Naturita site. This section summarizes the toxicological effects of the chemical contaminants and the carcinogenic potentials of the radionuclides and arsenic.

The following source materials were used to develop toxicological profiles on these chemical contaminants and the potentially carcinogenic radionuclides:

- The Integrated Risk Information System (IRIS) (EPA, 1994a).

- The Agency for Toxic Substances and Disease Registry Toxicological Profiles, published by the Department of Health and Human Services (DHHS).

- The Handbook on the Toxicology of Metals (Friberg et al., 1986).

- Peer-reviewed scientific literature when these review documents were not available.

Basing toxicity information on the standardized review documents cited above ensures consistency in risk evaluation at all UMTRA Project processing sites.

The toxicity profiles presented here focus on drinking water data in humans. Animal information is used only when human data are not available. Animal data are represented on the toxicity range graphs by widely spaced, dotted lines. Uncertainty about the beginning and ending point of an exposure range that produces specific toxic effects is represented by closely spaced dots.

\subsection{CONTAMINANT TOXICITY SUMMARIES}

The following summaries address the basic toxicokinetics and toxicity of the chemical contaminants of potential concern at the Naturita site. These contaminants are antimony, arsenic, manganese, molybdenum, selenium, sodium, sulfate, uranium, and vanadium. Although the toxic effects of these contaminants vary with exposure levels, toxic effects observed in the exposure range most relevant to contamination at this site are discussed in this document.

\subsubsection{Antimony}

\section{Absorption}

Antimony can be absorbed both through inhalation and ingestion. Antimony trioxide or mixture of antimony trioxide and pentoxide was absorbed through the skin in rabbits following application of high doses of these compounds (quantitative data are not available) (DHHS, 1992a). No quantitative data exist 
on the absorption of antimony from the gastrointestinal tract in humans (DHHS, 1992a). Based on animal studies, absorption of trivalent antimony salts from the gastrointestinal tract is estimated to be less than 10 percent in humans. Gastrointestinal absorption of antimony may be affected by various factors, including the chemical form of ingested antimony, age of exposed individuals and their diet (DHHS, 1992a). Although quantitative information is not available for all forms, rates for the gastrointestinal absorption in humans of 10 percent for antimony tartrate and 1 percent for all other forms of antimony have been identified (DHHS, 1992a). Based on geochemical models for the Naturita site, antimony exists in both pentavalent and trivalent forms in ground water (Table 3.3), with the pentavalent form being the predominant form.

\section{Tissue accumulation and clearance}

No human data are.available on the distribution of antimony following oral exposure. The major sites of antimony accumulation after oral exposure in laboratory animals are the gastrointestinal tract, liver, kidney, bone, lung, spleen, and thyroid gland (DHHS, 1992a). There was a lack of dose-relationship for the increase of antimony levels in these tissues. Species differences exist in the elimination of antimony from the tissues in animals. An elimination half-time was about 40 days for the thyroid gland in rats, and about 15 days for the liver, lung, and kidney in voles (DHHS, 1992a). A single study in mice revealed a higher antimony body burden during pregnancy (DHHS, 1992a).

No human or animal data are available on the excretion of antimony following oral exposures. Data obtained from human and animal studies in which antimony was administered parenterally provide some insight with respect to routes and rates of excretion from the body that can be anticipated after oral exposure in humans (DHHS, 1992a).

Antimony absorbed from the gastrointestinal tract appears to be excreted in the urine and feces to a variable degree, depending on the valence state (DHHS, 1992a). Pentavalent antimony injected intravenously or intramuscularly to humans or animals is excreted predominantly in the urine, whereas injected trivalent antimony is excreted mainly in the feces.

\section{Environmental sources of antimony}

Dietary antimony intake ranged from 0.25 to $1.25 \mathrm{mg} /$ day in a study of institutional diets for children in the United States (Friberg et al., 1986). Assuming an average body weight of $35 \mathrm{~kg}$, this intake is equivalent to 0.007 to $0.04 \mathrm{mg} / \mathrm{kg}$-day. However, a more recent study of nutrients in a human diet using mixed diet composites representative of the intake of a 25- to 30-year-old male suggested a daily dietary intake level was as low as $4.6 \mu \mathrm{g}$ of antimony (this corresponds to about $0.00007 \mathrm{mg} / \mathrm{kg}$-day for a 70-kg man) (DHHS, 1992a). 
In freshwater fish, antimony concentrations on the order of 3 micrograms per kilogram $(\mathrm{mg} / \mathrm{kg}$ ) wet weight have been reported (Friberg et al., 1986). Levels of 3 and $8 \mathrm{mg} / \mathrm{kg}$ have been found in milk and potato powder. Antimony is sometimes present in the binding coat between enamel and metal, especially in older cooking utensils, and can be dissolved by acidic food and drink when the enamel coating is worn. In soil, antimony usually ranges from 0.1 to $10 \mathrm{mg} / \mathrm{kg}$ dry weight (DW).

\section{Toxicity of antimony}

The only data available on antimony toxicity in orally exposed humans lother than side effects associated with therapeutic use of antimony compounds) came from the report on incidental ingestion of lemonade contaminated with potassium antimony tartrate (DHHS, 1992a). After drinking lemonade containing 0.013 percent antimony, 70 people developed acute symptoms, including burning stomach pain, colic, nausea, and vomiting. It is estimated that a $70-\mathrm{kg}$ adult consuming 300 milliliters $(\mathrm{mL})$ of lemonade would have received a dose of approximately $0.5 \mathrm{mg} / \mathrm{kg}$ (DHHS, 1992a).

One study indicated that female workers exposed in an antimony plant experienced a greater incidence of spontaneous abortions than did a control group of nonexposed working women. A high rate of premature deliveries among women who worked in antimony smelting and processing was also observed (Friberg et al., 1986). Reconstruction of dose and exposure conditions in the occupational setting is not available. Myocardial effects are among the best-characterized adverse health effects associated with repeated prolonged exposure to antimony in humans via inhalation in occupational settings (EPA, 1994a; DHHS, 1992a). The estimated no-observed-adverse-effect level for myocardial damage of about $0.5 \mathrm{mg} / \mathrm{m}^{3}$ is approximately equivalent to an oral dose of $0.003 \mathrm{mg} / \mathrm{kg}$-day for a $70-\mathrm{kg}$ man, where an uncertainty factor of 10 , for protection of sensitive individuals, is applied (EPA, 1994a).

In several studies involving laboratory animals (rats), prenatal and postnatal exposure to antimony trichloride in drinking water impaired the development of certain cardiovascular reflexes that are important in regulating systemic arterial blood pressure (DHHS, 1992a). However, because comparisons were not made between the hypotensive response in pups exposed prenatally and the response in pups exposed postnatally, the potential of antimony trichloride to produce developmental cardiovascular effects cannot be assessed based on these studies.

The EPA oral reference dose (RfD) for antimony is $0.0004 \mathrm{mg} / \mathrm{kg}$-day. The RfD is based on a lifetime study of rats exposed to antimony trioxide in drinking water. The lowest dose producing adverse health effects (increased mortality of animals and alteration of blood chemistry) was $0.42 \mathrm{mg} / \mathrm{kg}$-day (EPA, 1994a).

The health effects from exposure to antimony as a function of dose are summarized in Figure 5.1. 


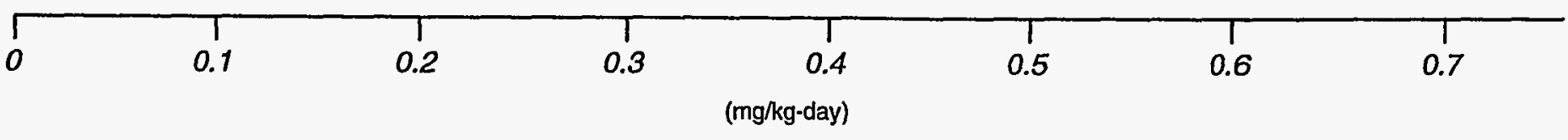

L J

DIETARY INTAKE LEVELS

A ORAL RfD $(0.0004 \mathrm{mg} / \mathrm{kg} \cdot$ day $)$

- NO-OBSERVED-ADVERSE EFFECT LEVEL FOR

MYOCARDIAL DAMAGE IN HUMANS $(0.003 \mathrm{mg} / \mathrm{kg}$-day);

DOSE RECONSTRUCTED FROM INHALATION

MILD TOXICITY IN RATS

(DECREASED LONGEVITY, ALTERED BLOOD CHEMISTRY) EXPOSURE DOSE

MILD TOXICITY IN HUMANS

(GASTROINTESTINAL DISTRESS AFTER ACUTE EXPOSURE)

FIGURE 5.1

ANTIMONY TOXICITY RANGES 


\subsubsection{Arsenic}

\section{Absorption}

Arsenic is absorbed through the gastrointestinal tract and via inhalation. Relative to gastrointestinal absorption, dermal absorption is negligible. In humans, approximately 80 percent of an ingested amount of dissolved inorganic trivalent (arsenite) or pentavalent arsenic (arsenate) is absorbed from the gastrointestinal tract (Pershagen and Vahter, 1979; Marafante and Vahter, 1987; DHHS, 1993).

\section{Tissue accumulation and clearance}

After absorption by the gastrointestinal tract, arsenic is transported via the blood to most tissues. In humans as well as in most animal species, exposure to either arsenite or arsenate leads to an initial accumulation in the liver, kidneys, and lungs. The clearance from these tissues is very rapid, and a long-term retention of arsenic is seen in organs rich in sulfhydryl-containing proteins, such as the hair, skin, squamous epithelium of the upper gastrointestinal tract, epididymis, thyroid, lens, and skeleton (Lindgren et al., 1982). Specific target tissue depends on the form of arsenic. Higher retention of arsenic occurs after exposure to trivalent arsenic than to the pentavalent form, and tissue distribution is altered (Webb, 1966; Casarett and Doull, 1991).

In humans and rats, inorganic arsenic passes through the placental barrier. It has also been demonstrated to enter both cow and human milk (Marcus and Rispin, 1988).

In the human body, where methylcobalamine acts as a major methyl group donor in the biotransformation process, inorganic arsenic is converted to methylated compounds. It has been demonstrated that the major site of arsenic methylation is the liver (Marcus and Rispin; 1988). Trivalent arsenic is the substrate for methylation, and pentavalent arsenic must be reduced to trivalent arsenic before methylation can occur. Dimethylarsenic acid is a major metabolite found in animals and humans. Methylation results in a detoxification of inorganic arsenic (about one order of magnitude per methyl group) and increases the rate of arsenic excretion from the body.

The major route of excretion following human exposure to inorganic arsenic is via the kidneys (Ishinishi et al., 1986). Only a few percent is excreted in feces. The rate of excretion in urine varies depending on the chemical form of arsenic, the duration of exposure, and the species exposed. In humans exposed to a single low dose of arsenite, about 35 percent was excreted in urine over a period of 48 hours (Buchet et al., 1980; 1981). In the case of continuous human intake over a few days, 60 to 70 percent of the daily dose is excreted in urine (Buchet et al., 1981). Following exposure to arsenate, the limited human data available indicate a rate of excretion similar to that of arsenite. Other, less 
important routes of elimination of inorganic arsenic include skin, hair, nails, and sweat.

After oral intake of radiolabeled pentavalent arsenic, 66 percent was excreted with a half-time of 2.1 days, 30 percent with a half-time of 9.5 days, and 3.7 percent with a half-time of 38 days (Marcus and Rispin, 1988).

\section{Environmental sources of arsenic}

Arsenic is ubiquitous in nature in both inorganic and organic compounds. Water is the major means of arsenic transport under natural conditions. In oxygenated water, arsenic occurs in a pentavalent form; under reducing conditions, the trivalent form predominates.

As a result of arsenic's widespread occurrence, the general human population is exposed to it primarily from drinking water and foodstuffs. Certain target groups are exposed to arsenic from industrial and agricultural uses. Medicinal use has also been a significant means of human exposure.

Drinking water usually contains a few micrograms of arsenic, predominantly as inorganic salts in the trivalent and pentavalent states (WHO, 1981; DHHS, 1993). Surveys of drinking water in the United States have revealed that over 99 percent of the public water supplies have arsenic levels below $0.05 \mathrm{mg} / \mathrm{L}$ (DHHS, 1993) $10.05 \mathrm{mg} / \mathrm{L}$ is an equivalent to $0.001 \mathrm{mg} / \mathrm{kg}$-day for a $70-\mathrm{kg}$ adult drinking two liters of water per day). However, concentrations of up to $1.1 \mathrm{mg} / \mathrm{L}$ in drinking water have been reported in Chile, Argentina, Taiwan, the United States, and the United Kingdom (WHO, 1981).

Seafood, meats, and grains contain the highest levels of arsenic. Much of the arsenic present in seafood is in organic forms, which are nontoxic (DHHS, 1993). For most people, the diet is the largest source of exposure, with average intakes of about $50 \mu \mathrm{g} /$ day, which corresponds to $0.0007 \mathrm{mg} / \mathrm{kg}$-day for a 70-kg man (DHHS, 1993). Wine and mineral waters can contain several hundred micrograms of arsenic per liter (Crecelius, 1977; WHO, 1981).

\section{Toxicity of arsenic}

Levels of exposure associated with arsenic toxicity vary with the valency form of the element. Trivalent arsenicals (arsenites) are considered somewhat more toxic than pentavalent (arsenates) (Morrison et al., 1989; DHHS, 1993), and inorganic arsenic compounds are more toxic than organic (Shannon and Strayer, 1989; DHHS, 1993). Based on.geochemical models for the Naturita site, arsenic exists primarily in the pentavalent form in ground water (Table 3.3). For arsenic trioxide, the reported estimated acute oral lethal dose in humans ranges from 70 to $300 \mathrm{mg}$ (1 to $4 \mathrm{mg} / \mathrm{kg}$ ) (EPA, 1984). Acute exposure to inorganic arsenic compounds may lead to severe inflammation of the gastrointestinal tract, encephalopathy, and acute renal failure after ingestion. 
Increasing chronic doses of arsenic ingested orally progressively produce systemic effects, including 1) arterial thickening in children and adults $(0.02 \mathrm{mg} / \mathrm{kg}$-day); 2) neurological symptoms, including peripheral neuropathy $(0.04 \mathrm{mg} / \mathrm{kg}$-day); 3) fibrosis of the liver $(0.05 \mathrm{mg} / \mathrm{kg}$-day); and 4) cirrhosis of the liver $(0.08 \mathrm{mg} / \mathrm{kg}$-day) (DHHS, 1993). Liver enlargement was observed at arsenic doses as low as $0.02 \mathrm{mg} / \mathrm{kg}$-day.

Chronic arsenic intoxications result from exposure to even small doses of arsenic over a long period of time. These intoxications are frequently caused by arsenic content in drinking water and in food. Changes of the skin leading to skin cancer are commonly seen in populations exposed to high concentrations of arsenic in drinking water. Endemic arsenic poisoning is seen in Cordoba, Argentina, where the concentration of arsenic in drinking water ranges from 0.9 to $3.4 \mathrm{mg} / \mathrm{L}$ (equivalent to 0.026 to $0.097 \mathrm{mg} / \mathrm{kg}$-day). Certain areas in Taiwan also have high natural arsenic concentrations in drinking water that cause Blackfoot disease (a peripheral extremity vascular disorder resulting in gangrene). A dose-response relationship between the incidence of Blackfoot disease and the duration of exposure to arsenic has been documented (Tseng, 1977; EPA, 1994a). The lowest dose of arsenic associated with Blackfoot disease in continuously exposed individuals has been determined to be $0.014 \mathrm{mg} / \mathrm{kg}$-day (DHHS, 1993).

Hyperpigmentation, hyperkeratosis, and skin cancer with prevalence of 7.1 percent, 18.4 percent, and 1.1 percent, respectively, were reported in Taiwanese studies of more than 40,000 people exposed to arsenic in drinking water at daily intakes ranging from 1.4 to $6.3 \mathrm{mg}$. However, hyperkeratosis and hyperpigmentation were observed at an exposure level as low as $0.014 \mathrm{mg} / \mathrm{kg}$-day (DHHS, 1993).

Teratogenic effects of arsenic compounds administered intravenously or intraperitoneally at high doses have been demonstrated in laboratory animals only (Ferm, 1971; Hood, 1972; EPA, 1984). Teratogenic effects, also referred to as birth defects, are defined as effects resulting in structural or functional anomalies in live offspring.

Certain characteristics of exposed human populations may influence arsenic toxicity at high exposure levels. Genetic dispositions (rapid versus poor acetylators) and protein-deficient diet may decrease the methylation of arsenic. This can result in an increased deposition of the element in the target organs (e.g., lung or skin).

The EPA oral reference dose for inorganic arsenic is based on results from Taiwanese studies where hyperpigmentation, keratosis and vascular complications were observed in people as a result of long-term drinking of water naturally contaminated with arsenic (EPA, 1994a). It was derived from an arithmetic mean $(0.009 \mathrm{mg} / \mathrm{L})$ of arsenic concentrations in drinking water that were not associated with adverse health effects no-observed-adverse-effect 
level (NOAEL) following drinking the water for a long time. This NOAEL also included estimation of arsenic intake from food. The uncertainty factor of 3 was applied to account for both the lack of data to preclude teratogenic or reproductive toxicity as a critical effect and to protect sensitive individuals. However, there are some. other uncertainties associated with these studies such as the possible presence of other contaminants in drinking water. Also, arsenic doses were not well characterized.

The EPA has classified inorganic arsenic as a Group A (human) carcinogen (EPA, 1994a), based on the occurrence of increased lung cancer mortality (in populations exposed primarily via inhalation) and of increased skin cancer prevalence (in populations exposed by consuming drinking water containing high concentrations of arsenic). The current slope factor (SF) for oral exposure to arsenic, given in Table 5.1, which is based on a unit cancer risk for skin cancer (the upper-bound excess cancer risk from lifetime exposure to water containing $1 \mu \mathrm{g}$ of arsenic/L) of $5 \times 10^{-5}$ calculated from a study by Tseng et al. (1968) (DHHS, 1993). This SF is currently under review by the EPA with respect to recent data suggesting arsenic ingestion may result in increased cancers in internal organs (bladder, kidneys, lungs, prostate, and liver) as well as skin cancers (EPA, 1994a; Wu et al., 1989). The health effects from exposure to arsenic as a function of dose are summarized in Figure 5.2.

\subsubsection{Manganese}

\section{Absorption}

Following ingestion, manganese absorption is homeostatically controlled: the absorption rate depends on both the amount ingested and the existing manganese levels in tissue. Adults absorb approximately 3 to 4 percent of dietary manganese (Saric, 1986). Manganese can be absorbed following exposure by inhalation, ingestion, and dermal contact. In humans, available data indicate that only 3 percent of an ingested dose of manganese chloride is absorbed (Mena et al., 1969). Manganese in water appears to be more efficiently absorbed than manganese in foodstuff (EPA, 1994a). The absorption rate is influenced by iron and other metals. In states of iron deficiency, manganese is actively absorbed from the intestine. Individuals with anemia can absorb more than twice the percentage of an ingested dose. However, in states of excess iron, manganese absorption is by diffusion only (Saric, 1986). High levels of dietary calcium and phosphorus are shown to increase the requirements for manganese in several species (Lönnerdal et al., 1987).

\section{Tissue accumulation and clearance}

Absorbed manganese is widely distributed throughout the body. The highest concentrations are found in the liver and kidney. The manganese elimination half-time from the human body is 2 to 5 weeks, depending on body stores. Manganese readily crosses the blood-brain barrier and is more slowly cleared 
Table 5.1 Toxicity values: potential carcinogenic effects

\begin{tabular}{|c|c|c|c|c|}
\hline Parameter & $\begin{array}{c}\text { Oral slope } \\
\text { factor }^{\circ}(\mathrm{pCi})^{-1} \\
(\mathrm{mg} / \mathrm{kg-day})^{-1}\end{array}$ & $\begin{array}{c}\text { Weight of } \\
\text { evidence } \\
\text { classification }\end{array}$ & Type of cancer & $\begin{array}{c}\text { Source of } \\
\text { slope factor }\end{array}$ \\
\hline $\begin{array}{l}\text { Arsenic, } \\
\text { inorganic }\end{array}$ & $1.8 \mathrm{E}+00^{c}$ & A & Skin & $\operatorname{IRIS}^{d}$ \\
\hline Lead-210 & 1.01E-09 & A & Bone & HEAST \\
\hline Polonium-210 & $3.26 E-10$ & A & Liver, kidney, spleen & HEAST \\
\hline Radium-226 ${ }^{\circ}$ & $2.96 \mathrm{E}-10$ & A & Bone & HEAST \\
\hline Radium-228 & $2.48 \mathrm{E}-10$ & A & Bone & HEAST \\
\hline Thorium-230 & 3.75E-11 & A & $f$ & HEAST \\
\hline Uranium-238 & $6.20 E-11$ & A & $\mathbf{g}$ & HEAST \\
\hline Uranium-234 & 4.44E-11 & A & g & HEAST \\
\hline \multicolumn{5}{|c|}{$\begin{array}{l}\text { For each individual radionuclide listed, oral slope factors (SFs) correspond to the risks } \\
\text { per unit intake (risk/pCi) for that radionuclide, except as noted. } \\
\text { bFrom EPA (1994b). } \\
\text { 'Oral slope factor is based on oral unit risk of } 5 \times 10^{-5} \text { (EPA, 1994a). } \\
{ }^{\text {d} F r o m ~ E P A ~(1994 a) . ~} \\
{ }^{\circ} \text { Oral SF includes the contributions from short-lived decay products, assuming equal } \\
\text { activity concentrations (i.e., secular equilibrium) with the principal nuclide in the } \\
\text { environment. } \\
\text { 'Target organs systems have not been identified for oral exposure to thorium. } \\
\text { 'No human or animal studies have shown a definite association between oral } \\
\text { exposure to uranium and development of cancer. }\end{array}$} \\
\hline
\end{tabular}




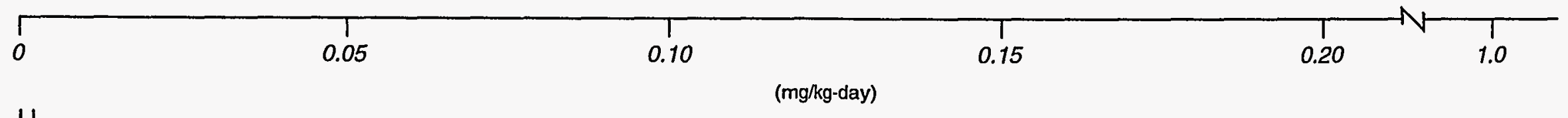

$U$

BACKGROUND INTAKE LEVELS FROM DRINKING WATER

1

AVERAGE DIETARY INTAKE $(0.0007 \mathrm{mg} / \mathrm{kg}$-day $)$

$\triangle$ ORAL RfD $(0.0003 \mathrm{mg} / \mathrm{kg}$-day $)$

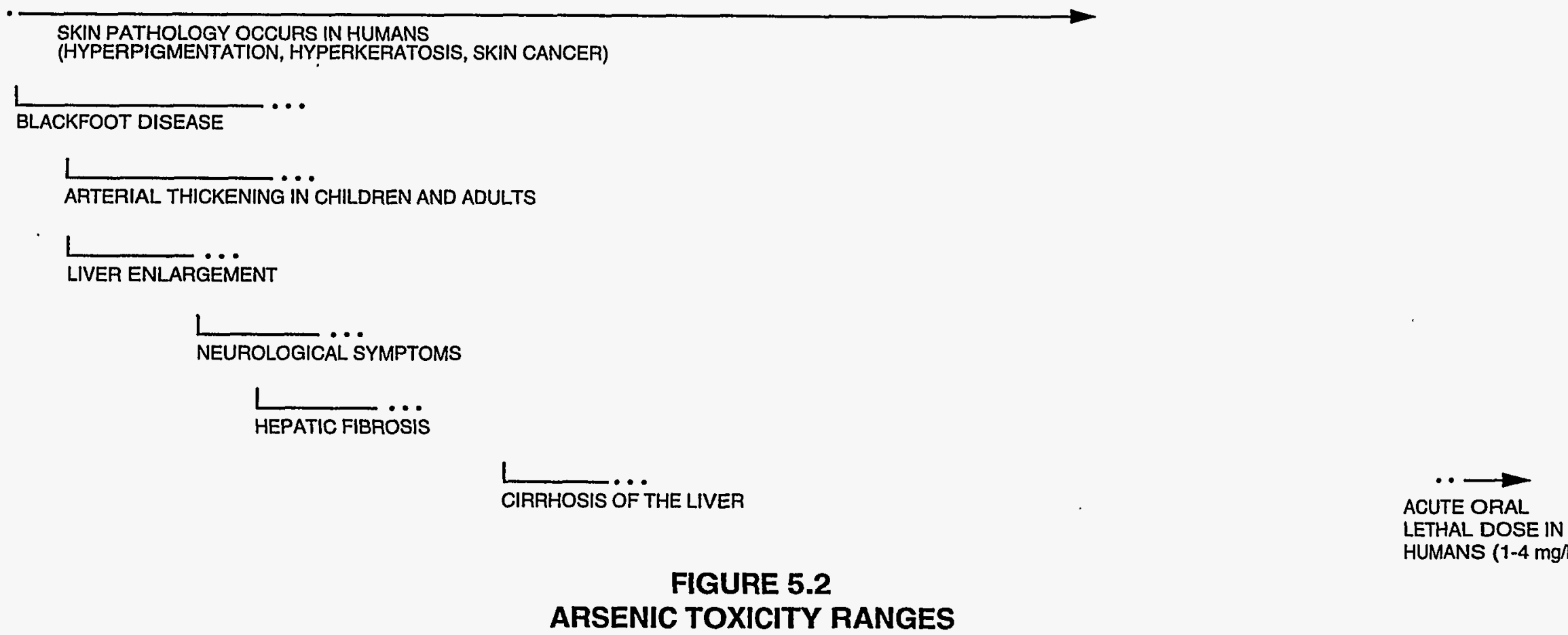


from the brain than from other tissue (Goyer, 1991). Normal concentrations in the brain are low, but the half-time in the brain is longer and the metal may accumulate in the brain with excessive absorption (National Research Council, 1973).

Absorbed manganese is rapidly eliminated from the blood and concentrates in mitochondria. Initial concentrations are greatest in the liver. Manganese penetrates the placental barrier in all species and is more uniformly distributed throughout the fetus than in adults. It is secreted into milk.

Absorbed manganese is almost totally secreted in bile and reabsorbed from the intestine as needed to maintain body levels. At excessive exposure levels, other gastrointestinal routes may participate. Excess manganese is eliminated in the feces; urinary excretion is negligible (Goyer, 1991; Saric, 1986).

\section{Environmental sources of manganese}

On the whole, food constitutes the major source of manganese intake for humans. The highest manganese concentrations are found in plants, especially wheat and rice. Drinking water generally contains less than $0.1 \mathrm{mg} / \mathrm{L}$. Manganese levels in soil range from 1 to $7000 \mathrm{mg} / \mathrm{kg}$, with an average of 600 to $900 \mathrm{mg} / \mathrm{kg}$. Mining and natural geological background variations contribute to this variability. Manganese bioaccumulates in marine mollusks up to 12,000-fold, and there is evidence for toxic effects in plants (phytotoxicity) and plant bioaccumulation. The Illinois Institute for Environmental Quality has recommended a criterion of 1 to $2 \mathrm{mg} / \mathrm{kg}$ for manganese in soil and $200 \mathrm{mg} / \mathrm{kg}$ in plants (Saric, 1986).

Variations in manganese intake can be explained to a large extent by differences in nutritional habits. In populations using cereals and rice as main food sources, the intake will be higher than in areas where meat and dairy products are a larger part of the diet. The average daily intake has been estimated to be between 2.0 to $8.8 \mathrm{mg} /$ day (0.03 to $0.13 \mathrm{mg} / \mathrm{kg}$-day) (EPA, 1994a), but intakes as high as $12.4 \mathrm{mg}$ (about $0.2 \mathrm{mg} / \mathrm{kg}$-day) are reported in countries with high cereal intake (Saric, 1986).

Drinking water generally results in an intake of less than $0.2 \mathrm{mg}$ $(0.003 \mathrm{mg} / \mathrm{kg}$-day), although some mineral waters can increase this amount by more than threefold (Saric, 1986). One study from Greece reported drinking water concentrations of manganese in excess of $2 \mathrm{mg} / \mathrm{L}$, which would result in daily intakes in the range of 0.06 to $0.07 \mathrm{mg} / \mathrm{kg}$-day (EPA, 1994a).

\section{Toxicity of manganese}

Manganese is an essential nutrient. The estimated safe and adequate daily dietary intake ranges from 0.03 to $0.07 \mathrm{mg} / \mathrm{kg}$-day for adults (Saric, 1986). The EPA (NOAEL) for drinking water is identified at $0.005 \mathrm{mg} / \mathrm{kg}$-day, while the lowest-observed-adverse-effect level (LOAEL) for drinking water is 
$0.06 \mathrm{mg} / \mathrm{kg}$-day (EPA, 1994a). The EPA RfD for drinking water of 0.005 $\mathrm{mg} / \mathrm{kg}$-day is based on human data (Kondakis et al., 1989). The study group was a population of older adults exposed to manganese in drinking water over a lifetime; because this population was considered sensitive, an uncertainty factor of 1 was applied (EPA, 1994a). The RfD for ingested food is $0.14 \mathrm{mg} / \mathrm{kg}$-day. Manganese in drinking water may be more bioavailable (i.e., more readily absorbed) than manganese in dietary food sources. This bioavailability would result in toxic effects at lower ingested doses in drinking water than in food (EPA, 1994a). However, insufficient data exist to quantify these differences.

Industrial settings are the largest source of data on chronic manganese toxicity. The data indicate that inhalation of manganese can result in a central nervous system disorder characterized by irritability, difficulty in walking, speech disturbances, and compulsive behavior that may include running, fighting, and singing. With continued exposure, this condition can progress to a mask-like face, retropulsion or propulsion, and a Parkinson-like syndrome. These effects are largely irreversible, although some recovery can be expected when exposure ceases (DHHS, 1992b). Metal-chelating agents are ineffective in treatment, but L-dopa has been effective in treatment (Goyer, 1991).

Information on the effects of manganese ingestion is limited. Because effects from manganese in drinking water can appear at lower manganese levels than in food sources, only studies on water consumption will be considered here. A Japanese study of 25 people drinking well water with manganese concentrations of $14 \mathrm{mg} / \mathrm{L}(0.4 \mathrm{mg} / \mathrm{kg}$-day estimated intake) reported symptoms of intoxication, including a mask-like face, muscle rigidity and tremors, and mental disturbances. Two deaths ( 8 percent) occurred among the intoxicated people. A Greek study of more than 4000 adults at least 50 years old drinking water with manganese concentrations varying from 0.081 to $2.3 \mathrm{mg} / \mathrm{L}$ lestimated intakes at $2 \mathrm{~L}$ per day for a $70-\mathrm{kg}$ individual range from 0.002 to $0.07 \mathrm{mg} / \mathrm{kg}$-day) showed varying degrees of neurological effects in individuals drinking from 0.007 to $0.07 \mathrm{mg}$ manganese $/ \mathrm{kg}$-day, but no effects in individuals drinking less than $0.005 \mathrm{mg} / \mathrm{kg}$-day (Kondakis et al., 1989). However, there are many limitations to these studies which make data interpretation difficult. Among the limitations is uncertainty regarding the exposure level or whether the effects seen were solely attributable to manganese. Despite these limitations, the similarity of the effects seen in the cases of oral exposure compared with those associated with inhalation exposure suggests that excess manganese intake by humans might lead to neurological injury (DHHS, 1992b).

The chemical form of manganese has complex effects on its toxicity. Although the more soluble forms are more readily absorbed from the gastrointestinal tract, they also appear to be more rapidly cleared. Exposure to insoluble forms results in lower manganese absorption but higher chronic tissue levels and therefore greater toxicity (EPA, 1994a). Information on the effects of various forms of manganese is limited. 
Few data are available on manganese toxicity in infants, but infants are probably more susceptible to manganese toxicity due to greater absorption and greater penetration into the central nervous system (EPA, 1994a; Saric, 1986). Figure 5.3 summarizes manganese toxicity as a function of dose.

\subsubsection{Molybdenum}

\section{Absorption}

Molybdenum absorption in the gastrointestinal tract depends on the species of the metal. Inorganic hexavalent forms such as molybdenum trioxide, sodium molybdate, and ammonium molybdate are readily absorbed from both food and water, whereas molybdenite is not. Based on the geochemical models for the Naturita site, all of the molybdenum exists in the form of well absorbable molybdate in ground water (Table 3.3). Human absorption rates of 40 to 70 percent have been observed for the soluble forms of molybdenum (Tipton et al., 1969; Robinsón et al., 1973; Alexander et al., 1974).

\section{Tissue accumulation and clearance}

In humans, the highest concentrations of molybdenum occur in the liver, kidney, and adrenals (Casarett and Doull, 1991). With normal dietary intake, molybdenum levels in the body slowly increase until approximately age 20 , then begin to decline steadily. Urine is the principal excretion route in humans.

Human studies indicate that the biological half-life in humans is considerably longer than in animals and may be as long as 2 weeks (Rosoff and Spencer, 1964).

\section{Environmental sources of molybdenum}

Molybdenum occurs naturally in combination with other metals, including uranium, lead, iron, cobalt, and calcium. Native soil concentrations can vary by as much as 2 orders of magnitude, from 0.1 to $10 \mathrm{mg} / \mathrm{kg}$, leading to large variations in molybdenum concentrations in plant materials. Natural concentrations in ground water are reported from 0.00011 to $0.0062 \mathrm{mg} / \mathrm{L}$. Human dietary intake of molybdenum is estimated at 0.05 to $0.24 \mathrm{mg}$ per day $(0.0007$ to $0.003 \mathrm{mg} / \mathrm{kg}$-day). The contribution of drinking water is estimated to range from 0 to 95 percent. The nutritional intake range for molybdenum is from 0.0015 to $0.0054 \mathrm{mg} / \mathrm{kg}$-day. No symptoms of molybdenum deficiency have been reported in humans. Nonetheless, molybdenum is an essential trace element that functions as a necessary constituent of several enzymes, including xanthine oxidase (which is involved in the metabolism of uric acid) and nitrate reductase (Friberg et al., 1986). 


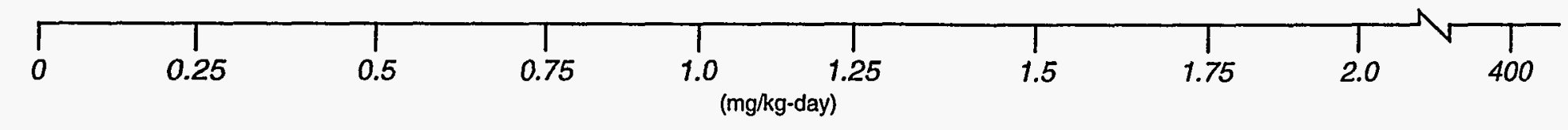

A BACKGROUND DRINKING WATER INTAKE $(0.003 \mathrm{mg} / \mathrm{kg}$-day)

$\sqcup$

DIETARY INTAKE FROM FOOD

$\triangle$ EPARfD - DRINKING WATER $(0.005 \mathrm{mg} / \mathrm{kg}$-day)

MILD NEUROLOGGICAL SYMPTOMS

PARKINSON-LIKE EFFECTS 


\section{Toxicity of molybdenum}

Acute toxic effects of molybdenum have not been reported. No adverse health effects have been reported with a chronic intake of less than $0.008 \mathrm{mg} / \mathrm{kg}$-day of molybdenum (EPA, 1994a). Molybdenum toxicity primarily is related to its interactions with copper and sulfur, leading to altered excretion patterns for these elements. Increased levels of molybdenum also increase the levels of xanthine oxidase, which is responsible for the production of uric acid. Uric acid can accumulate in joints, leading to symptoms of gout and other joint disorders.

A molybdenum intake of 0.008 to $0.022 \mathrm{mg} / \mathrm{kg}$-day can produce a mineral imbalance as a result of increased copper excretion (EPA, 1994a). Copper excretion is reported to double with molybdenum intake at the upper end of this range. Copper is an essential nutrient important in many metabolic pathways, including the synthesis and function of hemoglobin. A copper deficiency resulting from excess excretion will impair the oxygen-carrying capacity of the blood, and severe copper deficiencies can lead to hypochromic microcytic anemia. In humans, gout-like symptoms and joint deformities are reported in regions of Russia where elevated molybdenum concentrations in soil and subsequent increased molybdenum concentrations in food lead to molybdenum intakes in the range of 0.14 to $0.21 \mathrm{mg} / \mathrm{kg}$-day. The EPA oral reference dose of $0.005 \mathrm{mg} / \mathrm{kg}$-day for molybdenum was derived from results of these studies (EPA, 1994a). An uncertainty factor of 30 was used for two reasons: to protect the sensitive human population and to use the (LOAEL of $0.14 \mathrm{mg} / \mathrm{kg}$ day) rather than the preferred NOAEL which should be identified from a longterm study in a human population. Figure 5.4 summarizes the health effects of molybdenum as a function of dose.

\subsubsection{Selenium}

\section{Absorption}

Although water-soluble forms of selenium such as selenite are approximately 90 percent absorbed in the gastrointestinal tract in rats, humans show lower percentages of absorption ( 40 to 80 percent) (Bopp et al., 1982). Based on the geochemical models for the Naturita site, all of the selenium exists in the form of well absorbable selenite in ground water (Table 3.3). Absorption by ruminants is only $\mathbf{3 0}$ to 35 percent, probably due to bacterial reduction in the rumen. Absorption of the less soluble elemental selenium or selenium sulfide is poor in rats (Medinsky et al., 1981; Cummins and Kimura, 1971).

\section{Tissue accumulation and clearance}

Studies suggest similar distributions of selenium between humans and laboratory animals (Bopp et al., 1982). At low intake levels, selenium is retained and accumulates in the reproductive organs, brain, and thymus, with only transient accumulation in other organs. Selenite-derived selenium accumulates in the liver 


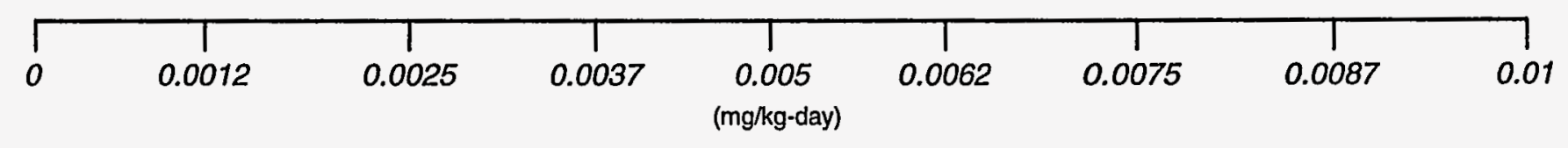

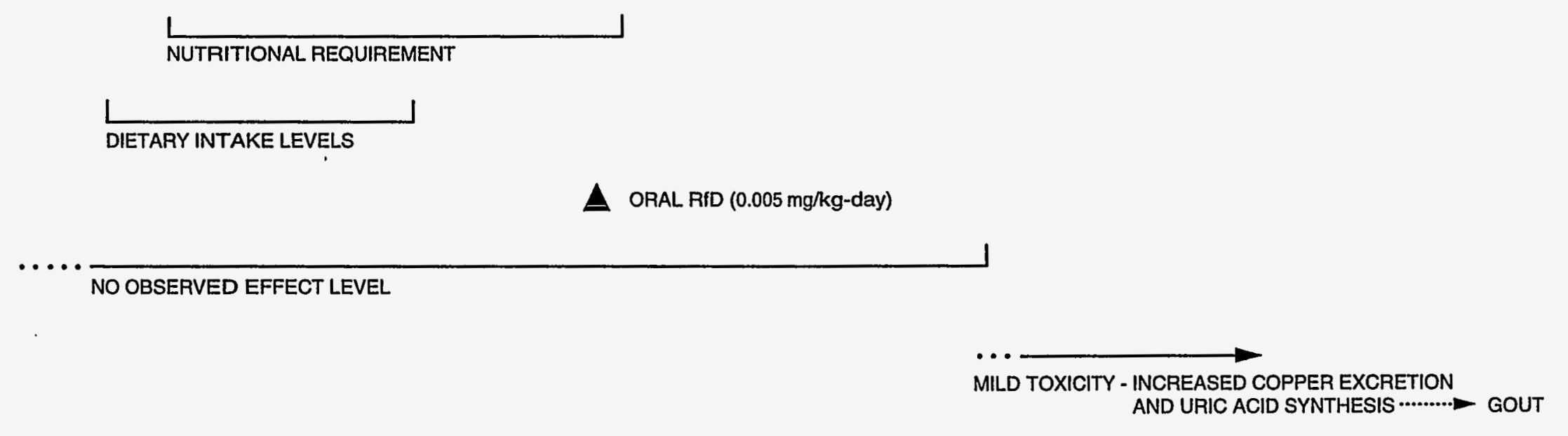

FIGURE 5.4

MOLYBDENUM TOXICITY RANGES 
and kidneys more rapidly than selenium derived from selenate (Millar et al., 1973). There is some indication that organically bound forms of selenium exist in a separate, more bioavailable pool than either selenite or selenate.

Selenium is a component of an enzyme glutathione peroxidase found in most human and animal tissues (DHHS, 1989). This enzyme is mainly involved in the metabolism and removal of hydrogen peroxide and lipid hydroperoxide from the body. Therefore, this enzyme protects cellular membranes and lipid-containing organelles from peroxidative damage. There are other human proteins that contain or require selenium. The metabolism of selenium involves pathways both for incorporation of selenium into the selenium-dependent enzymes and for excretion of selenium from the body.

Although urinary excretion is the primary route of selenium elimination under normal dietary conditions (67 percent), in deficiency states fecal excretion is the major pathway. At toxic doses, the major route of excretion is through expired air as dimethylselenide (50 to 60 percent) (Friberg et al., 1986). Although these data were obtained in rats, available data suggest that human excretion is similar (Bopp et al., 1982). The elimination of selenium in humans follows three phases with the following half-times: 1 day; 8 to 20 days; and 65 to 116 days.

\section{Environmental sources of selenium}

The main source of selenium for the general population is foods such as seafood, meat, and grains. Dietary intake of selenium in the United States ranges from 0.0007 to $0.0029 \mathrm{mg} / \mathrm{kg}$-day. Selenium concentrations in ground water and surface water range from 0.00006 to $0.400 \mathrm{mg} / \mathrm{L}$, with highs of $6 \mathrm{mg} / \mathrm{L}$ being reported (Friberg et al., 1986). Concentrations in U.S. public water supplies rarely exceed $0.010 \mathrm{mg} / \mathrm{L}$ (EPA, 1980). High selenium concentrations occur in volcanic rock $(0.120 \mathrm{mg}$ per gram) and in sandstone uranium deposits $(1.0 \mathrm{mg}$ per gram). The soil content of selenium varies widely, as does the rate of accumulation by plants: Although grasses and grains do not accumulate selenium in concentrations greater than $50 \mathrm{mg} / \mathrm{kg}$, some plants can accumulate as much as $10,000 \mathrm{mg} / \mathrm{kg}$ if grown in high-selenium regions. These high-accumulating plants are generally not used as food sources but can produce toxic effects if consumed by livestock.

\section{Toxicity of selenium}

Selenium is an essential nutrient. The RDA for adults is 0.04 to $0.07 \mathrm{mg} / \mathrm{day}$ (equivalent to $0.0006-0.001 \mathrm{mg} / \mathrm{kg}-$ day for a $70-\mathrm{kg}$ individual) (NRC, 1989). Although some biochemical alterations, including prolonged prothrombin time and reduced blood glutathione concentrations, can be observed with intakes of selenium from 0.0107 to $0.0121 \mathrm{mg} / \mathrm{kg}$-day, no clinical signs of selenosis are observed with these intakes (DHHS, 1989; EPA, 1994a). Mild toxicity, including hair loss or breakage, thickening and brittleness of nails, and a garlic odor in dermal excretions and breath, were reported in human populations with dietary intakes of selenium from $0.015 \mathrm{mg} / \mathrm{kg}$-day. However, selenium intake 
as low as $0.013 \mathrm{mg} / \mathrm{kg}$-day can produce symptoms of selenosis such as hair and nail loss in susceptible populations.

Persistent clinical symptoms of selenosis are attributed to the chronic dietary intake of selenium by human populations living in areas of China with high selenium concentrations in soil (from $7 \mathrm{mg} / \mathrm{kg}$ to $12 \mathrm{mg} / \mathrm{kg}$ ). Clinical signs observed included the characteristic garlic odor of excess selenium excretion in the breath and urine, thickened and brittle nails, hair and nail loss, lowered hemoglobin levels, mottled teeth, skin lesions, and central nervous system abnormalities (peripheral anesthesia, acroparesthesia, and pain in the extremities). Estimated selenium dietary intake was reported to be $0.018 \mathrm{mg} / \mathrm{kg}$-day for adult women and $0.021 \mathrm{mg} / \mathrm{kg}$-day for adult men (Yang et al., 1989a; 1989b). The average blood selenium concentration associated with this intake of selenium was $1.3 \mathrm{mg} / \mathrm{L}$ (ranging from $1.05 \mathrm{mg} / \mathrm{L}$ to $1.85 \mathrm{mg} / \mathrm{L}$ ). In the same study, symptoms of chronic selenosis (hair and nail loss and below-normal hemoglobin levels) were reported with a selenium intake of $0.071 \mathrm{mg} / \mathrm{kg}$-day. A serious outbreak of selenium poisoning, including the possible occurrence of neurotoxic effects such as peripheral anesthesia, acroparesthesia, and pain in extremities, was observed with selenium intake of $0.54 \mathrm{mg} / \mathrm{kg}$-day in both women and men. Protein intake by members of this population is unknown. The EPA oral reference dose of $0.005 \mathrm{mg} / \mathrm{kg}$-day for selenium is based on results from this study (EPA, 1994a). The EPA estimated the NOAEL for clinical selenosis at $0.015 \mathrm{mg} / \mathrm{kg}$-day of selenium and applied an uncertainty factor of 3 to this selenium level to protect sensitive human populations. These health effects are summarized in Figure $\mathbf{5 . 5}$ as a function of dose.

Ingestion of 350 to $4300 \mathrm{mg}$ (5 to $61 \mathrm{mg} / \mathrm{kg}$ ) of selenium by adults has produced vomiting, diarrhea, abdominal cramps, numbness in arms, and marked hair loss and irregular menstrual bleeding in women. Higher intakes can result in unsteady gait, cyanosis of mucous membranes, labored breathing, and sometimes death.

Symptoms of alkali disease and blind staggers have been seen in grazing livestock feeding over a long period of time upon selenium-accumulating plants in areas with high soil selenium content (Rosenfeld and Beath, 1964). These symptoms include neurological dysfunction such as. impaired vision, ataxia, disorientation, and respiratory distress.

\subsubsection{Sodium}

\section{Absorption}

Sodium is rapidly and fully absorbed from the gastrointestinal tract. The skin and lungs also absorb sodium rapidly, by simple diffusion and ion exchange (National Research Council, 1980). 

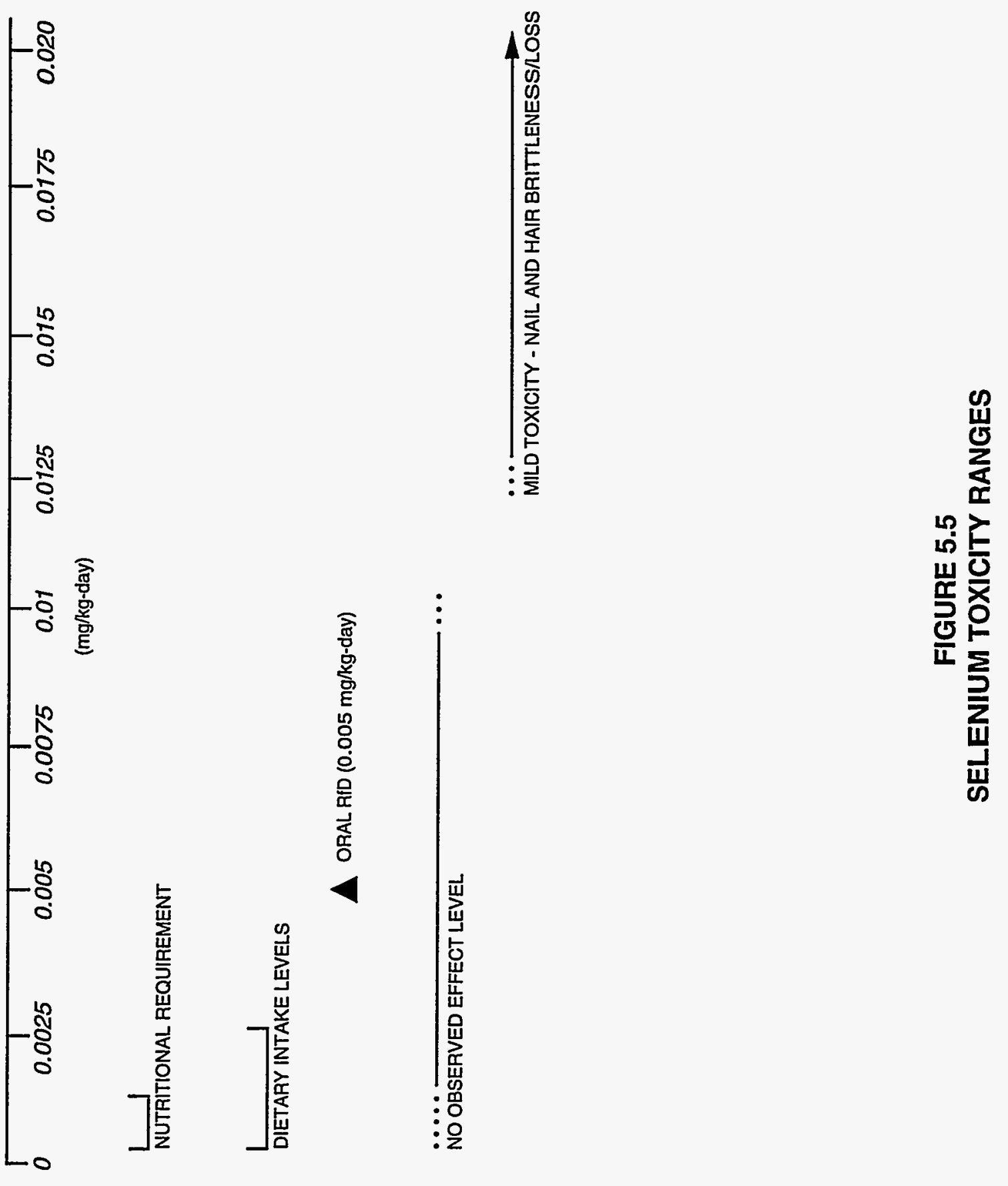


\section{Tissue accumulation and clearance}

Sodium is the major extracellular ion. The sodium ion is essential to the regulation of the acid-base balance and is an important contributor to extracellular osmolarity. It is an essential constituent in the electrophysiological functioning of cells and is required for impulse propagation in excitable tissues. Furthermore, sodium is essential for active nutrient transport, including the active transport of glucose across the intestinal mucosa. About $\mathbf{3 0}$ to 40 percent of the body's sodium is thought to be stored on the surfaces of the bone crystals, where it is easily recovered if blood sodium levels drop.

Sodium is excreted mainly in urine, with appreciable amounts also excreted in feces, sweat, and tears (Venugopal and Luckey, 1978). Mammalian renal sodium excretion is a two-phase process involving glomerular filtration and reabsorption in proximal tubules; of about 600 grams of sodium involved in 24-hour glomerular filtration, approximately 99.5 percent is reabsorbed in human adults. A homeostatic mechanism for sodium functions at the renal excretory level.

\section{Environmental sources of sodium}

The total sodium intake is influenced mainly by the amount of salt (sodium chloridel added to food, the inherent salt content of the foods consumed, and the amount of other sodium salts in the diet and in medication. Sodium is a natural constituent of both vegetable and animal products in varying concentrations. Other sources of sodium are drinking water, cooking water, soft drinks, and alcoholic beverages.

At 2 months, infants consume approximately $300 \mathrm{mg}$ of sodium a day; at 12 months, approximately $1400 \mathrm{mg} /$ day. Human breast milk contains $161 \mathrm{mg} / \mathrm{L}$, and cow's milk contains approximately $483 \mathrm{mg} / \mathrm{L}$ (Carson et al., 1986).

No RDA is set for sodium. The National Research Council recommends limiting daily sodium intake to less than $2400 \mathrm{mg}$ ( $34 \mathrm{mg} / \mathrm{kg}$-day); the American Heart Association recommends limiting dietary sodium intake to $3000 \mathrm{mg}$ daily. A healthy person requires about $115 \mathrm{mg}$ sodium daily $(1.6 \mathrm{mg} / \mathrm{kg}$-day), yet sodium dietary intake is estimated at 57 to $85 \mathrm{mg} / \mathrm{kg}$-day. However, dietary sodium intakes as high as $134 \mathrm{mg} / \mathrm{kg}$-day are reported (National Research Council, 1980).

The sodium content of drinking water is extremely variable. Analyses of water supply systems indicate sodium concentrations in 630 systems range from less than 1 to $402 \mathrm{mg} / \mathrm{L}$ (resulting in sodium intake from less than 0.03 to $11 \mathrm{mg} / \mathrm{kg}$-day), with 42 percent greater than $20 \mathrm{mg} / \mathrm{L}$ and 3 percent over $200 \mathrm{mg} / \mathrm{L}$ (Carson et al., 1986). 


\section{Toxicity of sodium}

Symptoms of acute sodium chloride toxicity accompanied by visible edema may occur in healthy adult males with an intake as low as 35 to 40 grams of salt per day (200 to $223 \mathrm{mg} / \mathrm{kg}$-day, because sodium is 39 percent of the weight of sodium chloride) (Meneely and Battarbee, 1976). The mean lethal dose of sodium for humans is reportedly $3230 \mathrm{mg} / \mathrm{kg}$ (Venugopal and Luckey, 1978).

Epidemiological studies indicate that long-term, excessive sodium intake is one of many factors associated with hypertension in humans. A high sodium-topotassium ratio in the diet may be detrimental to persons susceptible to high blood pressure. Some adults, however, tolerate chronic intake above $\mathbf{4 0}$ grams of sodium chloride per day (equivalent to $223 \mathrm{mg} / \mathrm{kg}$-day) (Carson et al., 1986).

Research indicates that critical levels of sodium ingestion cause blood pressure to rise with age, leading to hypertension. Hypertension was absent (Freis (1976) with sodium intake below $227 \mathrm{mg} / \mathrm{day}$ ( $3 \mathrm{mg} / \mathrm{kg}$-day for a $70-\mathrm{kg}$ adult). In the range of 227 to $1591 \mathrm{mg} /$ day ( 3 to $23 \mathrm{mg} / \mathrm{kg}$-day for a $70-\mathrm{kg}$ adult), a few cases of hypertension may appear, while in the range of 1591 to 8000 $\mathrm{mg} /$ day (23 to $114 \mathrm{mg} / \mathrm{kg}$-day for a $70-\mathrm{kg}$ adult), approximately 15 percent of adults exhibit hypertension. When sodium intake rises above $8000 \mathrm{mg} / \mathrm{day}$, hypertension may be found in about 30 percent of the population. Because sodium chloride is present in nearly all processed and packaged foods, limiting dietary intake is difficult. The average daily dietary intake in the United States often causes hypertensive effects.

Drinking water generally contains relatively low levels of sodium and therefore does not significantly contribute to the total intake unless sodium is at higherthan-average levels in the water supply. However, people on sodium-restricted diets can obtain a significant portion of daily sodium from drinking water. Because the kidney is the major organ involved in regulating sodium balance, individuals with compromised kidney function may be placed on a low-sodium diet. Other individuals may be on low-sodium diets to control hypertension. Because of the high prevalence of such individuals in our society, the American Heart Association has proposed that public drinking water supplies in the United States adopt a standard of $20 \mathrm{mg} / \mathrm{L}$ sodium (Calabrese and Tuthill, 1977). This standard measure would limit the additional intake of sodium from drinking water to approximately $0.6 \mathrm{mg} / \mathrm{kg}$-day for a $70-\mathrm{kg}$ adult. Figure 5.6 summarizes the potential health effects of sodium as a function of dose.

\subsubsection{Sulfate}

\section{Absorption}

Following oral ingestion, soluble salts of sulfate are well absorbed from the intestine (about 90 percent at low doses, i.e., less than $50 \mathrm{mg} / \mathrm{kg}$ ) and 

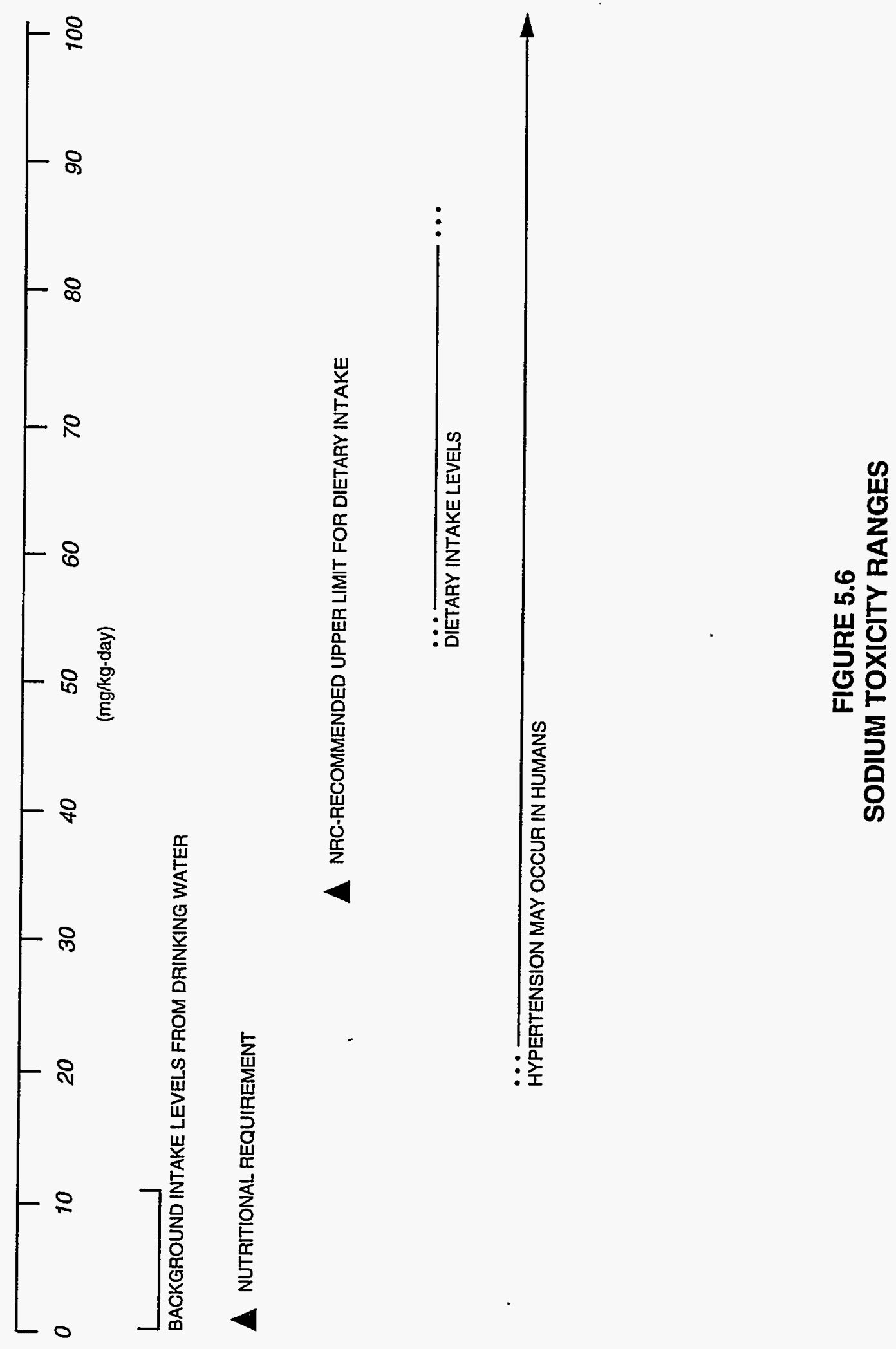
distributed throughout the body (EPA, 1992b). At higher doses (50 to 100 $\mathrm{mg} / \mathrm{kg}$ body weight) sulfate is incompletely absorbed (about 60 to 70 percent), which results in diarrhea.

Tissue accumulation and clearance

In humans, sulfate is a normal component of both extracellular and intracellular fluids (EPA, 1992b).

Ingesting high levels of sulfate results in transient increases in both blood and urine concentrations (EPA, 1992b). Inorganic sulfate is eliminated from the body almost entirely in urine without biotransformation (Morris and Levy, 1983). Approximately 50 percent of a $75-\mathrm{mg} / \mathrm{kg}$ dose is excreted over 72 hours (EPA, $1992 \mathrm{~b})$. The urinary excretion mechanism is transport-limited and can become saturated at high doses of sulfate. Excess sulfate may be excreted in feces in its inorganic form. To date, no data indicate that sulfate accumulates, even with chronic ingestion of above-normal levels.

Sulfate is used to biosynthesize collagen, cartilage, and dentin and to form sulfate esters of both endogenous compounds (such as lipids and steroids) and exogenous compounds (such as phenols). Sulfation is important in detoxication pathways because it increases the solubility of these compounds, enhancing their excretion in the urine. Exposure to high concentrations of compounds that are conjugated with sulfate and excreted can produce a transient decrease in plasma sulfate concentrations.

\section{Environmental sources of sulfate}

In 1978, drinking water sulfate concentrations in the western United States (EPA, 1992b) ranged from 0 to $820 \mathrm{mg} / \mathrm{L}$, with a mean concentration of $99 \mathrm{mg} / \mathrm{L}$ (which corresponds to sulfate daily intake of up to about $23 \mathrm{mg} / \mathrm{kg}$-day for a 70-kg man drinking $2 \mathrm{~L}$ of water per day, with an average of about $3 \mathrm{mg}$ sulfate $/ \mathrm{kg}$-day). The highest sulfate concentrations in drinking water of $1110 \mathrm{mg} / \mathrm{L}$ were reported in California (EPA, 1992b). This amount of sulfate in drinking water can result in a daily intake of $32 \mathrm{mg} / \mathrm{kg}$-day (assuming that a $70-\mathrm{kg}$ man ingests $2 \mathrm{~L}$ of water daily). The EPA estimates a normal sulfate intake range of 0.00023 to $0.0064 \mathrm{mg} / \mathrm{kg}$-day from air. Estimates on sulfate intake from food are not available.

\section{Toxicity of sulfate}

Little information is available on the toxic effects of sulfate on humans (EPA, 1992b). There are no health problems reported following chronic exposure to high concentrations of sulfate. The effects of the sulfate ion are limited to its laxative effect following short-term exposure (EPA, 1992b).

Sulfate salts of magnesium and sodium are used medicinally as cathartics. High concentrations of unabsorbed sulfate salts in the gut can pull large amounts of 
water into the gut, greatly increasing the normal volume of feces (EPA, 1992b). This action is also the basis of sulfate's toxic effects. Ingestion of excessive doses of cathartics without corresponding water ingestion leads to dehydration (EPA, 1992b). Extreme dehydration may lead to death.

Toxicity in humans is primarily manifested in diarrhea; the severity of the diarrhea is dose-dependent. The effect is reversible and diarthea discontinues after ceasation of exposure. About 5 grams of sodium sulfate or magnesium sulfate in a single dose produces diarrhea in most adults (Chien et al., 1968). This corresponds to sulfate intake of about $30 \mathrm{mg} / \mathrm{kg}$. It is generally accepted that cathartic effects are commonly experienced by people introduced to drinking water with sulfate concentrations above $600 \mathrm{mg} / \mathrm{L}$ (equivalent to above $17 \mathrm{mg} / \mathrm{kg}$-day for a 70-kg man drinking $2 \mathrm{~L}$ of water a day) (Chien et al., 1968; EPA, 1992b). Such water is usually a little bitter. If only taste of water is considered, sulfate water concentration should not exceed $400 \mathrm{mg} / \mathrm{L}$ (Chien et al., 1968; EPA, 1992b). In regions with high sulfate concentrations in the drinking water, such as Saskatchewan where well water may contain from 400 to $1000 \mathrm{mg} / \mathrm{L}$ of sulfate (from about 11 to $29 \mathrm{mg} / \mathrm{kg}$-day for a $70-\mathrm{kg}$ man drinking $2 \mathrm{~L}$ of water a dayl, residents adapt to the taste and find the water palatable (Chien et al., 1968). They also become immune to the laxative action of these levels of sulfate in their drinking water. These results appear to be consistent with data from North Dakota. A survey of 248 private well users in North Dakota indicated that sulfate concentration of 1,000 to $1,500 \mathrm{mg}$ sulfate per liter (equivalent to $29-43 \mathrm{mg}$ sulfate $/ \mathrm{kg}$-day for a $70-\mathrm{kg}$ man drinking $2 \mathrm{~L}$ of water a day) caused diarrhea in 62 percent of respondents (Moore, 1952, as cited in EPA, 1992b). In those exposed to sulfate concentrations from 200 to $500 \mathrm{mg} / \mathrm{L}$, approximately 20 percent reported laxative effects; however, no dose-response was observed in this group. Infants appear to be the most susceptible population for sulfate-induced diarrhea. Also, some data indicate that diabetic and elderly populations with compromised kidney function may be more sensitive than healthy adults to the effects of sulfates (EPA, 1992b).

Three infants were reported to develop diarrhea from sulfate in drinking water at concentrations from 475 to $680 \mathrm{mg} / \mathrm{L}$ (equivalent to $80-114 \mathrm{mg} / \mathrm{kg}$-day for a 4-kg infant drinking $0.67 \mathrm{~L}$ of water a day) (Chien et al., 1968). These infants recovered from diarrhea when water with high sulfate levels was replaced with "safe water" (sulfate concentration was not reported). Three other cases of severe diarrhea in infants $(5,10$, and 12 months old) were reported following ingestion of well water with sulfate content of 630,720 , and $1150 \mathrm{mg} / \mathrm{L}$ (Chien et al., 1968). These levels of sulfate correspond to sulfate intakes of about 106,121 , and $193 \mathrm{mg} / \mathrm{kg}$-day, assuming that a $4-\mathrm{kg}$ infant drinks $0.67 \mathrm{~L}$ of water a day. In two cases, diarrhea developed promptly; the third infant developed persistent diarrhea several days after the family moved to the area with high sulfate content in drinking water. In all cases, recovery was dependent upon substitution of water low in sulfate for the well water. Also, in all there cases infectious etiology of diarrhea was excluded; however, neither the nature nor the concentrations of the other constituents present in the water were specified. Adults (parents) drinking water with sulfate content of 630 and 
$720 \mathrm{mg} / \mathrm{L}(18$ and $21 \mathrm{mg} / \mathrm{kg}$-day for a 70-kg man drinking $2 \mathrm{~L}$ of water daily) showed no health problems. However, intermittent diarrhea developed in adults and children (age unknown) drinking water with $1150 \mathrm{mg}$ sulfate per liter (equivalent to $33 \mathrm{mg} / \mathrm{kg}$-day for a $70-\mathrm{kg}$ man drinking $2 \mathrm{~L}$ of water daily). The onset of the diarrhea was about two weeks after the family moved to the area. Figure 5.7 summarizes these health effects as a function of dose.

Sulfate toxicity data are based primarily on epidemiologic studies of human adults and infants who report to hospitals with symptoms of sulfate exposure. In most cases, exposure doses have been back-calculated from sampling their drinking water. Therefore, these data do not represent well-controlled studies with readily defined dosage ranges.

Based on the study by Chien et al. (1968) and data from North Dakota evaluated by Moore (1952), as cited in EPA, (1992b), the EPA has proposed the sulfate primary drinking water standard of $500 \mathrm{mg} / \mathrm{L}$ (40 CFR Parts 141, 142, and 143 (1994)).

\subsubsection{Uranium}

The uranium that occurs naturally at UMTRA Project sites consists of three radioactive isotopes: uranium-234, uranium-235, and uranium-238. More than 99 percent of natural uranium occurs in the form of uranium-238 (Cothern and Lappenbusch, 1983). Uranium-238 undergoes radioactive decay by emitting alpha particles to form uranium-234, thorium-230, radium-226, radon-222, polonium-210, lead-210, and other radioisotopes. Figure 5.8 summarizes the radioactive decay chain of uranium-238 and uranium-234: Because all natural uranium isotopes are radioactive, the hazards of a high uranium intake are from both its chemical toxicity and its potential radiological damage. The chemical toxicity of natural uranium is discussed here; the carcinogenic potential associated with exposure to radioactive isotopes of natural uranium is discussed in Section 5.3.

\section{Absorption}

Uranium absorption in the gastrointestinal tract depends on the solubility of the uranium compounds. The hexavalent uranium compounds, especially the uranyl salts, are water soluble, while tetravalent compounds generally are not (Weigel, 1983). However, only a small fraction of the soluble compounds is absorbed. Wrenn et al. (1985) have determined human gastrointestinal absorption rates of 0.76 to 7.8 percent.

Uranium may absorb through the skin when applied in concentrated solutions (the concentration level was not reported). The extent of absorption appears to be dose-dependent. 


\begin{tabular}{|c|c|c|c|c|c|c|c}
\hline & 1 & 1 & 1 & 1 & 1 & 1 \\
0 & 50 & 100 & 150 & $\begin{array}{c}200 \\
\text { (mg/kg-day) }\end{array}$ & 250 & 300 & 400
\end{tabular}

Lلـ

DACKGROUND INTAKE LEVELS FROM

DRINKING WATER BY ADULTS

L...

NO OBBSERVED EFFECTS IN ADULTS

ii. TOXICITY RANGING FROM

MILD TOXICITY RANGING FROM LAXATIVE EFFECT IN ADULTS TO DIARRHEA IN INFANTS

S̈EVERE TOXICITY - PERSISTENT INFANT DIARRHEA LEADING TO DEHYDRATION

FIGURE 5.7

SULFATE TOXICITY RANGES 


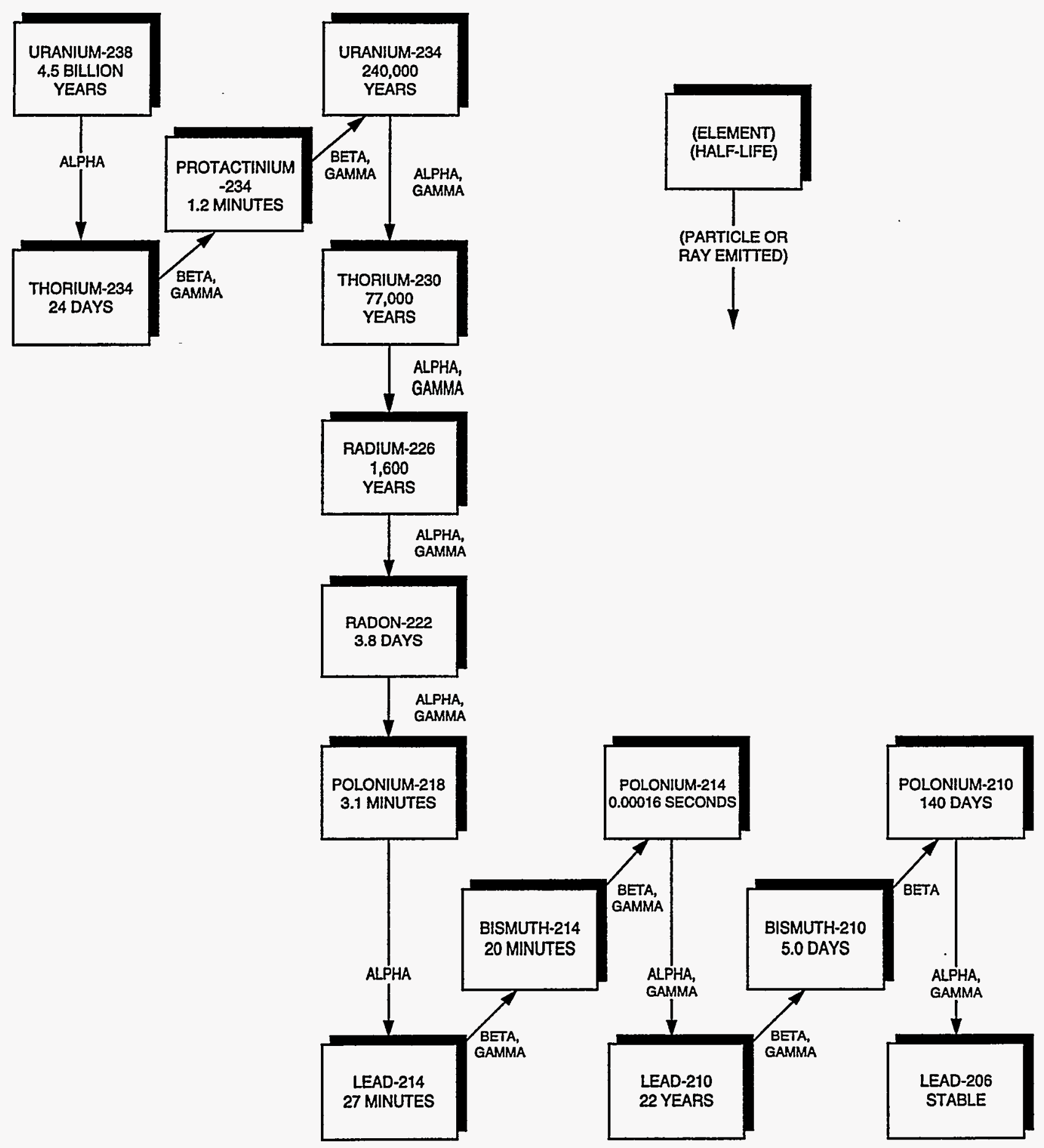

MODIFIED FROM SHLEIEN, 1992; ALL THE HALF-LIFE VALUES ARE ROUNDED TO THE TWO SIGNIFICANT DIGITS.

FIGURE 5.8

HALF-LIVES AND EMISSIONS FROM DECAY CHAIN OF URANIUM-238 


\section{Tissue accumulation and clearance}

In humans exposed to background levels of uranium, the highest concentrations were found in the bones, muscles, lungs, liver, and kidneys (Fisenne et al., 1988). Uranium retention in bone consists of a short retention half-time of $\mathbf{2 0}$ days, followed by a long retention half-time of $\mathbf{5 0 0 0}$ days for the remainder (Tracy et al., 1992).

In body fluids, uranium tends to convert into water-soluble hexavalent uranium (Berlin and Rudell, 1986). Approximately 60 percent of the uranium in plasma complexes with low-molecular-weight anions (e.g., bicarbonates, citrates), while the remaining 40 percent binds to the plasma protein transferrin (Stevens et al., 1980). Following oral exposure to uranium, humans excrete more than 90 percent of the dose in the feces. Of the small percent that is absorbed (typically less than 5 percent), animal studies show that approximately 60 percent is excreted through the urine within 24 hours, whereas the remainder is distributed to the skeleton and soft tissue; 98 percent of that amount is excreted within 7 days (Ballou et al., 1986; Leach et al., 1984; Sullivan et al., 1986). A small portion of the absorbed uranium is retained for a longer period.

\section{Environmental sources of uranium}

Uranium is a ubiquitous element, present in the earth's crust at approximately $4 \mathrm{ppm}$. Uranium concentrations in ground water and surface water average $1 \mathrm{pCi} / \mathrm{L}$ and $3 \mathrm{pCi} / \mathrm{L}$, respectively lequivalent to 0.001 and $0.004 \mathrm{mg} / \mathrm{L}$, assuming $1 \mathrm{mg}$ of uranium equals $686 \mathrm{pCi}$ ) (NCRP, 1984). The extent of uptake from the soil into plant tissues depends on the plant species and the depth of its root system (Berlin and Rudell, 1986). Tracy et al. (1983) report plant uranium concentrations averaging $0.075 \mu \mathrm{g} / \mathrm{kg}$ of fresh plant material.

The main dietary source of natural uranium for the general population is food (e.g., potatoes, grains, meat, and fresh fish) that may contain uranium concentrations between 10 and $100 \mu \mathrm{g} / \mathrm{kg}$ (Prister, 1969). The total uranium dietary intake from consuming average foods is approximately $1 \mu \mathrm{g} /$ day; approximately 20 to 50 percent of that total can come from drinking water. Cereals and vegetables, particularly root crops, probably contribute most to daily uranium intake (Berlin and Rudell, 1986).

\section{Toxicity of uranium}

No human deaths are reported that are definitely attributable to uranium ingestion; therefore, no lethal dose has been determined for humans. Lethal doses of uranium $\left(L D_{50,23}\right)$ are reported to be as low as $14 \mathrm{mg} / \mathrm{kg}$-day following 23-day oral exposure, depending on the solubility of the uranium compound tested (higher solubility compounds have greater toxicity), exposure route, and 
animal species. High doses of uranium cause complete kidney and respiratory failure.

No chronic toxic effects are reported in humans following oral exposure to uranium. Data from populations occupationally exposed to high concentrations of uranium compounds through inhalation and information from studies on experimental animals indicate that the critical organ for chronic uranium toxicity is the proximal tubule of the kidney (Friberg et al., 1986). In humans, chemical injury reveals itself by increased catalase excretion in urine and proteinuria. Dose-response data for the toxic effects of uranium on the human kidney are limited.

The LOAEL of uranyl nitrate that caused moderate renal damage was given to rabbits in diet at $2.8 \mathrm{mg}$ uranium per kilogram per day (Maynard and Hodge, 1949). The EPA oral reference dose of $0.003 \mathrm{mg} / \mathrm{kg}$-day was derived based on this study (EPA, 1994a). The EPA applied an uncertainty factor of 1000 to the LOAEL $(2.8 \mathrm{mg} / \mathrm{kg}$-day $)$, which reflects intraspecies and interspecies variability and an uncertainty associated with the use of a LOAEL rather than the preferred use of a NOAEL. Figure 5.9 summarizes the health effects of uranium as a function of dose.

\subsubsection{Vanadium}

\section{Absorption}

Absorption of vanadium from the gastrointestinal tract is low. The International Commission on Radiological Protection estimate for the absorption of soluble vanadium compounds is 2 percent (ICRP, 1960), but the WHO (1988) states that absorption of even very soluble forms of vanadium is less than 1 percent from the gastrointestinal tract (WHO, 1988). Limited human data (from three individuals) have suggested that as much as 10 percent of a repeated oral dose may be absorbed (Proescher et al., 1917; Tipton et al., 1969). Soluble vanadium compounds that are inhaled and deposited are more readily absorbed (about 25 percent) (WHO, 1988). Although soluble forms of vanadium may be absorbed through the skin, absorption via this route is probably minimal (EPA, 1977; WHO, 1988).

\section{Tissue accumulation and clearance}

Vanadium is found in all body tissues in concentrations ranging from $0.08 \mu \mathrm{g}$ per gram wet weight in spleen tissue to $0.14 \mu \mathrm{g}$ per gram in brain and heart tissue and $0.33 \mu \mathrm{g}$ per gram in aorta tissue (Yakawa and Suzuki-Yasumoto, 1980). Concentrations of vanadium in human blood serum are reported to be 0.016 to 0.939 nanograms per milliliter $(\mathrm{ng} / \mathrm{mL})$. In hair, concentrations of vanadium ranging from 20 to $60 \mathrm{ng}$ per gram have been reported by different authors, with higher values found in manic-depressive patients ( $57 \mathrm{ng}$ per gram) than in normal control groups (29 ng per gram). 


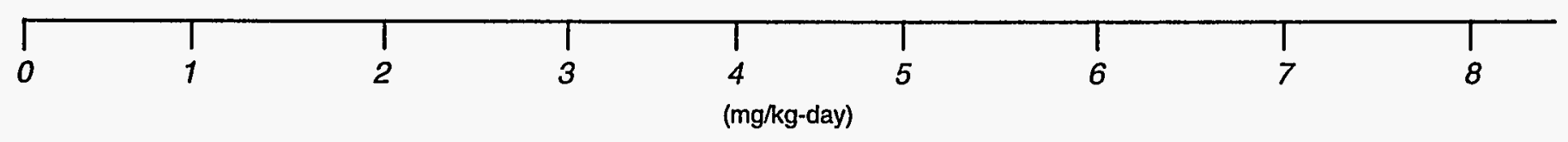

1

DIETARY INTAKE

$\triangle$ ORAL RID $(0.003 \mathrm{mg} / \mathrm{kg}$-day)

NO OBSERVED EFFECTS IN EITHER MICE OR RATS

(SUFFICIENT HUMAN DATA NOT AVAILABLE)

\section{L.P $\cdot>$}

(RABBITS, RENAL DAMAGE)

FIGURE 5.9

NONCARCINOGENIC URANIUM TOXICITY RANGES 
The distribution of vanadium in humans following oral exposure may be extrapolated from animal studies. In acute-duration exposures, vanadium is rapidly distributed, primarily in the bones. After intermediate-duration exposure, vanadium concentrations reaching the tissues are low, with the kidneys, bones, liver, and lungs initially showing the highest levels.

Vanadium is an element and is not metabolized. However, in the body, there is an interconversion of two oxidation states of vanadium: vanadyl and vanadate. Vanadium can reversibly bind to the protein transferrin in the blood and then be taken up into erythrocytes. There is a slower uptake of vanadyl into erythrocytes compared to the vanadate form, possibly due to the time required for the vanadyl form to be oxidized to vanadate. Initially, vanadyl leaves the blood more rapidly than vanadate, possibly because of the slower vanadyl uptake into cells (Harris et al., 1984). Five hours after administration, blood clearance is essentially identical for the two forms.

Because vanadium is poorly absorbed in the gastrointestinal tract, a large percentage of vanadium in rats is excreted unabsorbed in the feces following oral exposure. In rats, the principal route of excretion of the small absorbed portion of vanadium is through the kidneys. The mean urinary output per 24 hours is reported to be $10 \mu \mathrm{g}$.

\section{Environmental sources of vanadium}

Elemental vanadium does not occur in nature, but its compounds exist in more than 50 different mineral ores and in association with fossil fuels. The single largest release of vanadium to the atmosphere occurs through the combustion of fossil fuels, particularly residual fuel oils. The largest amount of vanadium released to soil and water occurs through natural weathering of geological formations (Byerrum et al., 1974; Van Zinderen Bakker and Jaworski, 1980).

Food constitutes the major source of exposure to vanadium for the general population (Lagerkvist et al., 1986). As a whole, dietary intake is estimated to be 6 to $18 \mu \mathrm{g} /$ day (Pennington and Jones, 1987), although other estimates from older studies using different (and possibly less sensitive) analytical methods have been as high as $2 \mathrm{mg} / \mathrm{day}$ (Schroeder et al., 1963).

Drinking water is not considered an important source of vanadium exposure for the general population. Water samples taken from across the United States show 92 percent with values below $10 \mu \mathrm{g} / \mathrm{L}$. Typical values appear to be around $1 \mu \mathrm{g} / \mathrm{L}$ (Lagerkvist et al., 1986). The estimated daily intake of vanadium by inhalation is $1 \mu \mathrm{g}$ (Byrne and Kosta, 1978).

Although vanadium is considered an essential element for chickens and rats, there is no certainty about human dietary requirements. For animals, the daily requirement is about 10 to $25 \mu \mathrm{g} /$ day (Pennington and Jones, 1987). 


\section{Toxicity of vanadium}

In laboratory animals, the toxicity of vanadium varies with the animal species and route of administration (WHO, 1988). Smaller animals (rats and mice) tolerate vanadium better than larger animals (rabbits or horses). Toxicity of vanadium is low with oral exposure, moderate by inhalation, and high by injection. The toxicity of vanadium also varies with the nature of the compound (WHO, 1988). Toxicity increases as valence increases, with pentavalent vanadium being the most toxic. Based on geochemical models for the Naturita site, all of the vanadium exists in the form of pentavalent vanadate in ground water (Table 3.3).

The major adverse health effect to humans from vanadium is seen in workers exposed to large amounts of vanadium pentoxide dusts. The probable oral lethal dose of vanadium pentoxide for humans is between 5 and $50 \mathrm{mg} / \mathrm{kg}$ (Gosselin et al., 1976). No adverse health effects have been reported from ingestion of vanadium at levels normally found in food or water (Waters, 1977).

Systemic effects of vanadium excessive exposure have been observed in the liver, kidneys, nervous and cardiovascular systems, and blood-forming organs. Metabolic effects include interference with the biosynthesis of cystine and cholesterol, depression and stimulation of phospholipid synthesis, and, at higher concentrations, inhibition of serotonin oxidation. Other effects of vanadium on mammalian metabolism include depression of phospholipid synthesis (Snyder and Cornatzer, 1958), reduction of coenzyme $Q$ levels in mitochondria (Aiyar and Sreenivasan, 1961), and stimulation of monoamine oxidase, which oxidizes serotonin (Perry et al., 1955).

Vanadium salts were given to patients in several experimental studies to reduce cholesterol levels (Curran et al., 1959; Somerville and Davies, 1962; Dimond et al., 1963; Schroeder et al., 1963). The doses of vanadium in these studies varied from 7 to $30 \mathrm{mg} /$ day lequivalent to $0.1-0.4 \mathrm{mg} / \mathrm{kg}$-day for a $70-\mathrm{kg}$ individual). Transient decreases in serum cholesterol levels were observed in some patients, as were loosened stool or diarrhea and intestinal cramps. Green tongue, a hallmark of vanadium exposure, was observed in all patients.

A relationship between the concentration of vanadium in drinking water and the incidence of dental caries in children is reported by Tank and Storvick (1960). Dental caries incidence in children aged 7 to 11 years was reduced three times (compared to controls) by applying ammonium vanadate in glycerol to the teeth (Belehova, 1969). This relationship was not found in other studies (Hadjimarkos, 1966; 1968).

It has been suggested that raised tissue levels of vanadium are important in the etiology of manic-depressive illness. Improvement after treatment with ascorbic acid or reduced vanadium intake was seen both in manic and depressed patients. 
Although animal studies have reported impaired conditioned reflexes following doses of vanadium from $0.05 \mathrm{mg} / \mathrm{kg}$-day (after 6 months of exposure) to $0.5 \mathrm{mg} / \mathrm{kg}$-day (after 21 days of exposure), effects on the nervous system have not been observed following repeated oral administration of vanadium in humans. Workers exposed by inhalation to fairly high concentrations of vanadium compounds have reported nonspecific symptoms, including headache, weakness, vomiting, nausea, and ringing of the ears (WHO, 1988). These symptoms disappeared after ceasation of exposure.

Available data on vanadium toxicity are insufficient to evaluate its effect on cholesterol levels, iron metabolism, blood-cell production, and mutagenesis. However, due to poor absorption from the gastrointestinal tract, the metal is not considered very toxic following oral administration (WHO, 1988). The EPA oral RfD of $0.007 \mathrm{mg} / \mathrm{kg}$-day was obtained from a lifetime drinking water study with vanadyl sulfate in rats (EPA, 1987a; EPA, 1994b; Schroeder et al., 1970). Vanadyl sulfate at $5 \mathrm{mg} / \mathrm{L}$ in drinking water did not produce toxicity in exposed animals over their lifetime (Schroeder et al., 1970). None of the parameters studied (growth and body weight, survival and longevity, glucose and cholesterol levels in the blood, and glucose level and proteins in the urine) was affected when compared with the control. The intake level of vanadium estimated from this study is $0.7 \mathrm{mg} / \mathrm{kg}$-day (DHHS, 1992c) and it represents a NOAEL for the kidney and other systemic effects. The EPA applied an uncertainty factor of 100 to a NOAEL to account for uncertainties associated with intraspecies and interspecies variability (EPA, 1994b). The toxicity of vanadium is summarized in Figure 5.10.

\subsection{CONTAMINANT INTERACTIONS}

Some information is available on potential interactions between contaminants found at UMTRA Project sites. However, discussions of potential interactions can generally be presented only qualitatively. In addition to physiological variables between individuals that can affect toxicity, uncertainties in interactions also result from 1) differences in the relative exposure concentrations of the different contaminants compared to the concentrations tested experimentally; 2) the presence of additional ground water constituents in sufficient quantities to modify predicted toxicities even though they themselves are not considered contaminants of potential concern for human health. Therefore, the interactions described below should be recognized as factors that can influence the predicted toxicity, although the precise nature and magnitude of that influence cannot be determined.

A primary concern at the Naturita site is the potential for interactions between metals. Interactions between several similar metals can alter the predicted absorption, distribution in the body, metabolism, clearance, or toxicity of a metal of interest.

For example, the gastrointestinal absorption, and consequently toxicity, of manganese can be considerably increased under conditions of low dietary iron 

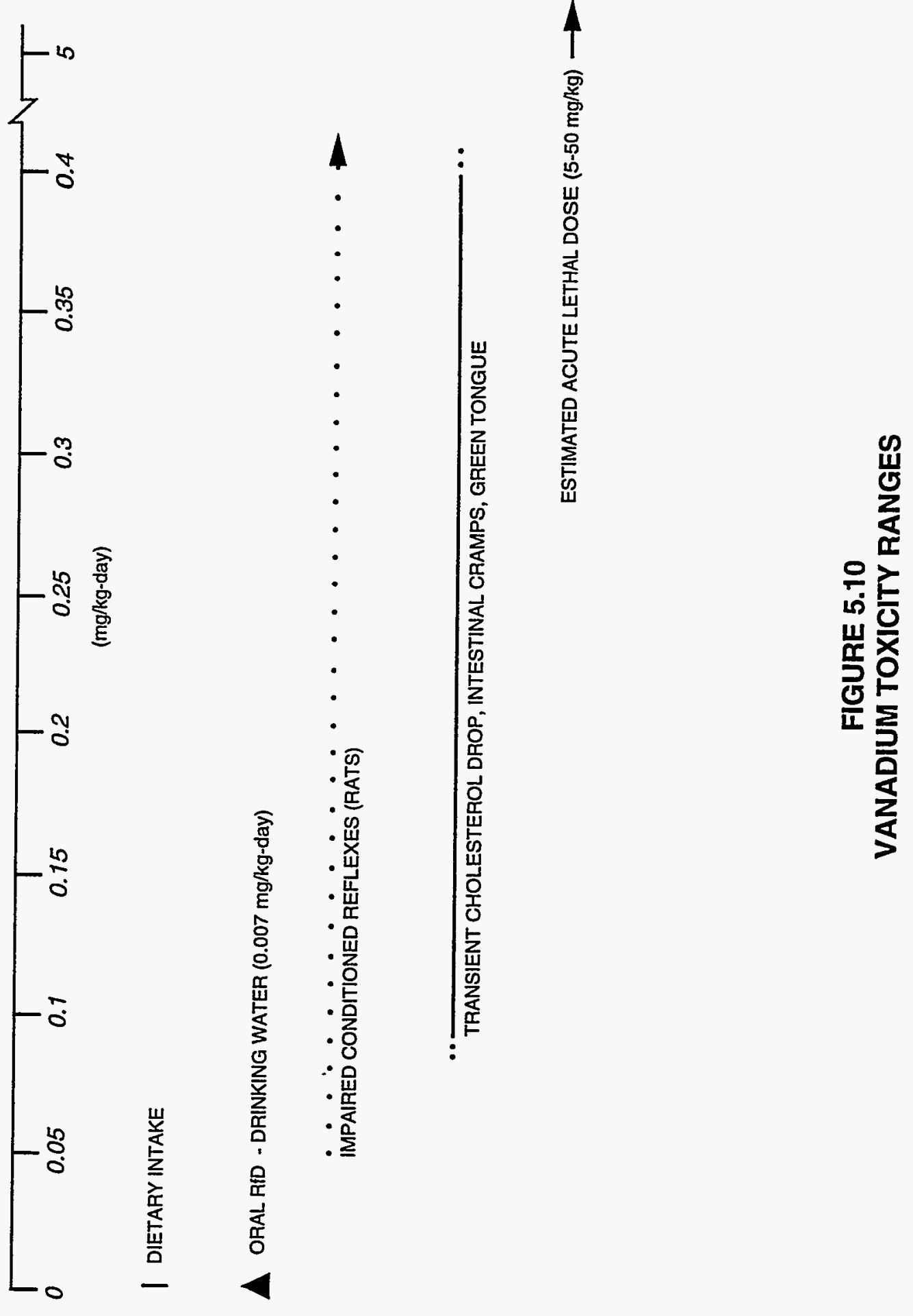
concentrations (DHHS, 1992d). Short-term effects of this type probably result from kinetic competition between iron and manganese for a limited number of binding sites on intestinal transport enzymes; while longer-term effects of iron deficiency are probably the result of adaptive changes in the level of intestinal transport capacity. Aluminum can decrease the intestinal absorption of fluoride in humans, therefore, it may have a protective effect against fluoride toxicity (DHHS, 1992d). Because calcium and strontium are competitive with respect to their absorptive sites, and excess of any of these elements may partially inhibit the absorption of another. Oral administration of vanadium may interfere with copper metabolism by inhibiting the intestinal absorption of copper, leading to copper deficiency. Copper deficiency may be triggered by the presence of molybdenum at levels observed at the Naturita site.

Manganese can induce synthesis of the metal-binding protein metallothionein (DHHS, 1992b). The formation of metallothionein-manganese complex would enhance manganese excretion, decreasing its toxicity.

A single study in mice suggests that vanadium and manganese interact, producing some alterations in behavioral development of the pups as compared to either element administered alone (DHHS, 1992c).

Selenium interacts with a wide range of elements, including arsenic, fluoride, and sulfate (Friberg et al., 1986; DHHS, 1989). Selenium and arsenic together can reduce their respective toxicities. However, some methylated metabolites of selenium can increase the toxicity of arsenic. Fluoride may increase the toxicity of inorganic compounds of selenium in rats when both elements are administered in drinking water. The effect of this interaction can manifest as decreased growth and increased mortality. However, the severity of this effect appears to depend upon the dose. Sulfate can also interact with selenium, but the result of interaction is inconsistent. Sulfate can reduce some toxic effects of selenium, but not others such as liver damage from high doses of selenium.

Sulfate also interacts in a complex manner with molybdenum and copper. Sulfate reduces molybdenum accumulation by competing for protein carriers and enhances its excretion by inhibiting tubular reabsorption. Molybdenum can produce a functional copper deficiency. The antagonism of molybdenum to copper is augmented by sulfate. Ruminants seem to be the most susceptible species to imbalances between molybdenum, copper, and sulfate. In ruminants, copper sulfate can protect against molybdenum toxicity. It has also been suggested that sulfide (a reduced form of sulfate) can displace molybdate in the body. In laboratory animal models, the toxicity of molybdenum is more pronounced in situations where dietary copper intake is low (EPA, 1994a).

Because ingesting high levels of sulfate produces diarrhea that leads to dehydration, and ingesting high levels of sodium and chloride leads to water retention, a physiological interaction might be expected to occur with simultaneous ingestion of all of them. However, available data do not predict the net effects of chronic ingestion of sulfate and sodium chloride at high 
concentrations. Although high-concentration sodium chloride solutions are used to treat diarrhea-induced hyponatremia and hypochloremic metabolic alkalosis, the electrolyte concentrations in these solutions are physiologically balanced. Disproportionally high sodium and chloride levels could intensify the electrolyte loss produced by severe diarrhea.

No information has been found on interactions of antimony and uranium with other metals present in the alluvium ground water at the Naturita site. However, the common target organ suggests that uranium, arsenic, vanadium, molybdenum, and manganese interact to enhance kidney toxicity. In addition, diarrhea-induced dehydration may cause contaminants excreted in urine to concentrate in the kidney. Thus, diarrhea-induced dehydration may enhance the predicted toxicities of these contaminants.

\subsection{CONTAMINANT RISK FACTORS}

The EPA Office of Research and Development has calculated acceptable intake values, or RfDs, for long-term (chronic) exposure to noncarcinogens. These values are estimates of route-specific exposure levels that would not be expected to cause adverse effects when exposure occurs for a considerable portion of the lifetime. The RfDs include safety factors to account for uncertainties associated with limitations of the toxicological data base. These safety factors include accounting for uncertainties associated with extrapolating results from animal studies to humans, accounting for response variabilities in sensitive individuals, and accounting for uncertainties associated with extrapolation from a LOAEL to a NOAEL and from shorter term or subchronic exposures to chronic exposures. These values are updated quarterly and are published in the Health Effects Assessment Summary Tables (HEAST). Following more stringent review, they are published through the EPA's Integrated Risk Information System (IRIS) data base. The most recent oral RfDs for the noncarcinogenic contaminants of potential concern are summarized in Table 5.2 .

The EPA currently classifies all radionuclides as Group A, or known human carcinogens, based on their property of emitting ionizing radiation and on the evidence provided by epidemiological studies of radiation-induced cancer in humans. At sufficiently high doses, ionizing radiation acts as a complete carcinogen (both initiator and promoter), capable of increasing the probability of cancer development (EPA, 1994b). However, the actual risk is difficult to estimate, particularly for the low doses encountered in the environment.

Most of the reliable data were obtained under conditions of high doses delivered acutely. It is not clear whether cancer risks at lower doses are doseproportional (i.e., the linear dose-response hypothesis) or whether the risk is greatly reduced at low doses and rates (i.e., the threshold hypothesis) (Latarjet, 1992; Shadley and Wiencke, 1989; Rigaud et al., 1993; Lazo, 1994; Oftedal, 1989; Casarett and Doull, 1991). A conservative assumption rejects the 


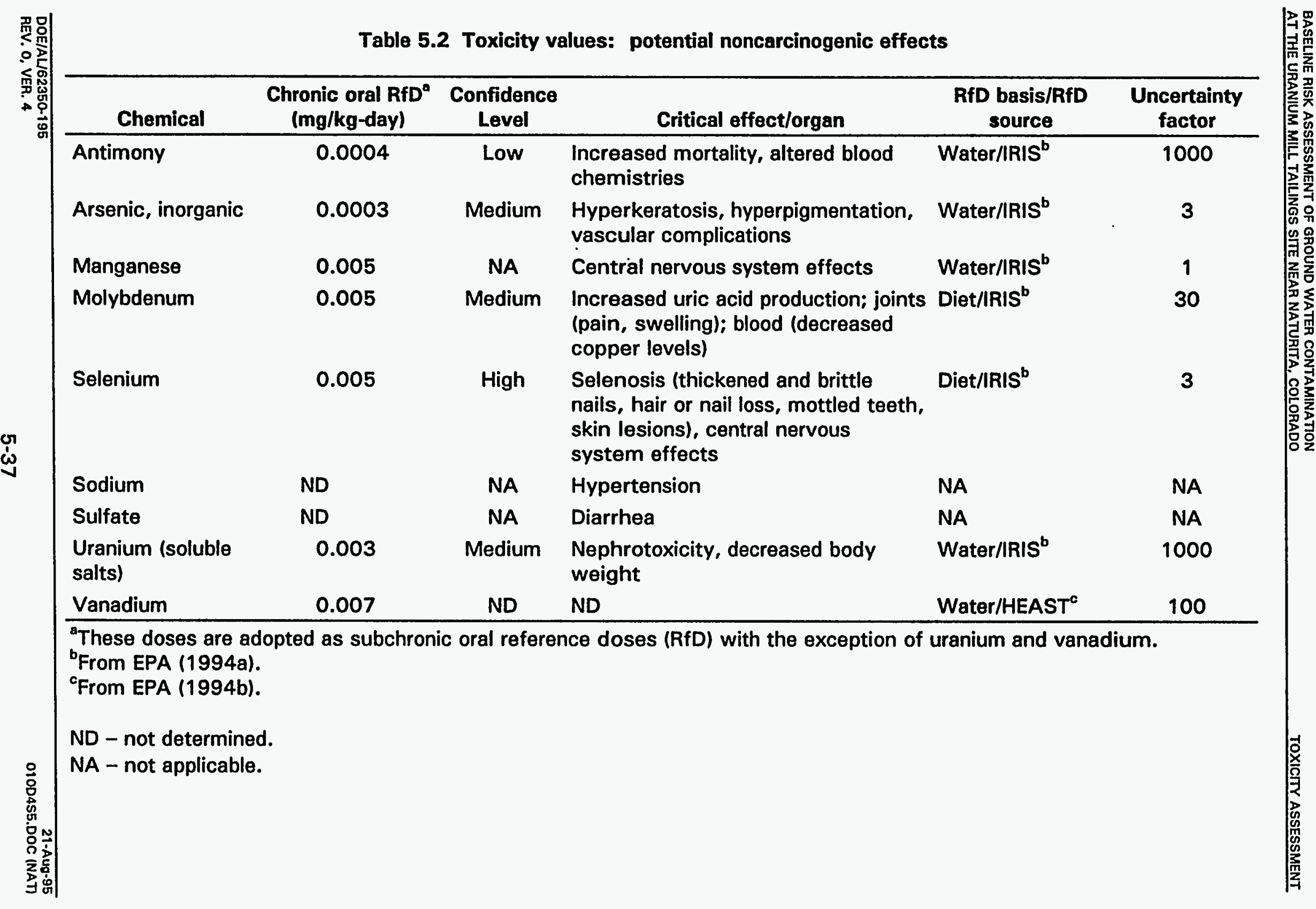


threshold hypothesis and assumes that any dose and dose rate add to the risk of cancer.

Risk factors published in HEAST and IRIS correlate the intake of carcinogens over a lifetime with the increased excess cancer risk from that exposure. The most recent cancer slope factors for the uranium-234/-238 radioactive decay series, radium-228 and the chemical carcinogen arsenic are given in Table 5.1 . 


\subsection{HUMAN HEALTH RISK EVALUATION}

Health risks to an individual or population are evaluated by combining the results of both the exposure and toxicity assessments. As discussed in Section 5.0, potential adverse health effects and their severity depend on the amount of the contaminant an individual takes into his or her body. At lower levels, some contaminants associated with the uranium processing are beneficial to health, because they are essential nutrients. At higher levels, these same elements can cause adverse health effects. Also, some individuals may be more sensitive to a given contaminant at the same level of exposure than others.

\subsection{POTENTIAL NONCARCINOGENIC HEALTH EFFECTS}

\subsubsection{Alluvial ground water potential use}

The results from the exposure assessment showing either the highest intake-tobody-weight ratios (i.e., highest doses) or the toxicologically most sensitive group of population are used to evaluate potential health effects of noncarcinogens. Infant exposures are used to evaluate the health risks of sulfate exposure, because this is the most toxicologically sensitive population. Although infants appear to be more sensitive than other groups of population to manganese toxicity, insufficient data are available to support a quantitative analysis. Therefore, for antimony, arsenic, manganese, molybdenum, selenium, sodium, uranium, and vanadium, the highest intake-to-body-weight group is children 1 to 10 years old.

Exposure to sulfate presents the most significant health risk associated with the contaminated ground water at the Naturita site. As can be seen in Figure 6.1 about 70 percent of the exposure distribution for sulfate is in the range where mild diarrhea could be expected in infants, and about 4 percent of the expected exposures is in the range of severe diarrhea, which can lead to dehydration. Further, these effects would be expected after very short-term exposures. However, the sulfate concentrations may cause the water to be unpalatable to infants, thus reducing their exposure.

Because the predicted sulfate toxicity from drinking water is serious, and because this is the only exposure pathway for infants, any additive contribution from other dietary or environmental sources would not alter the interpretation of health risks.

The exposure distribution for infants is based on tap water intake rates across a population that includes breast-fed and canned-formula-fed infants. Infants consuming powdered or concentrated formula reconstituted with well water could be in the upper percentiles of this exposure distribution and would be at higher risk of severe diarrhea. 


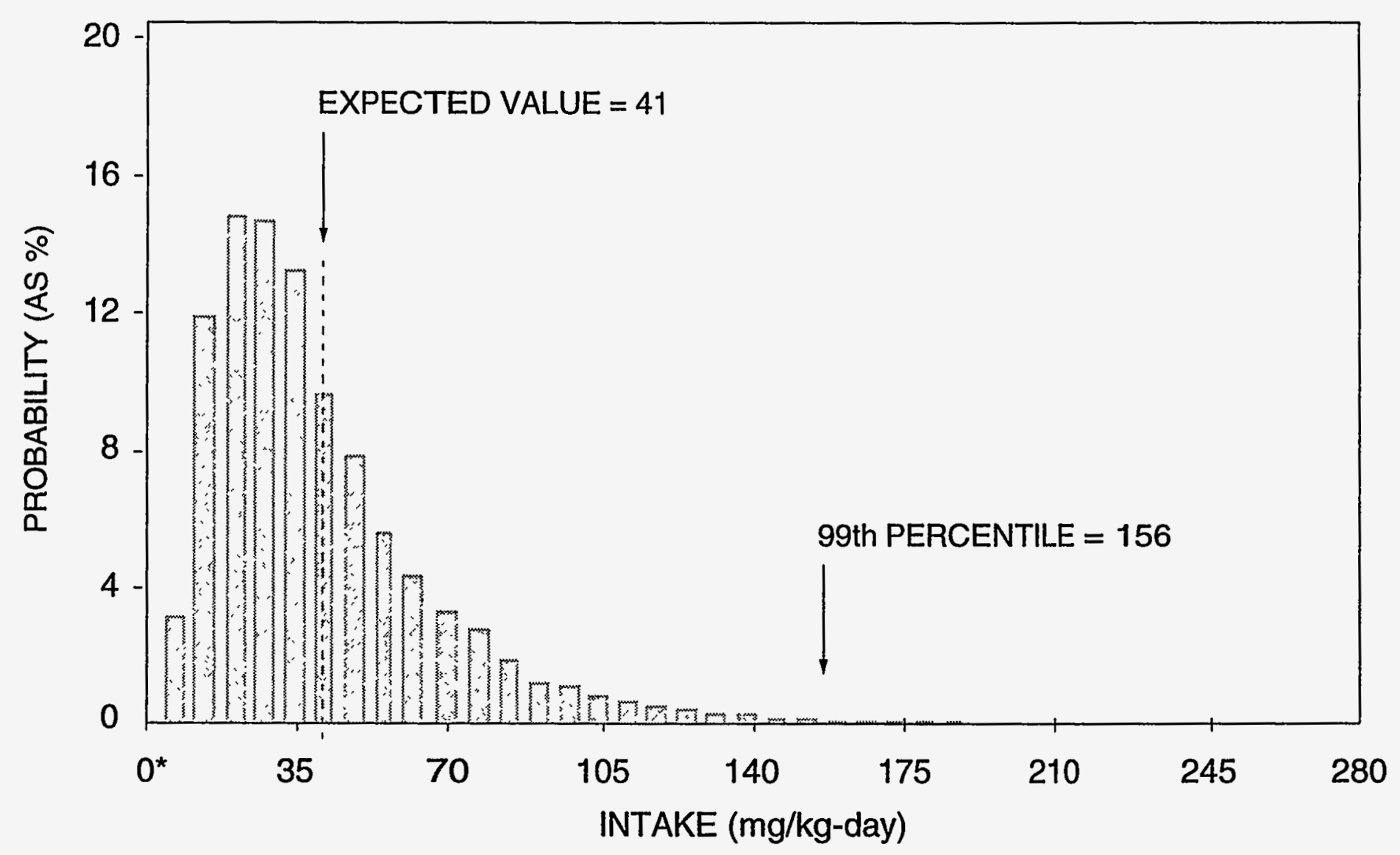

\section{BACKGROUND INTAKE LEVELS}

MILD TOXICITY RANGING FROM LAXATIVE EFFECTS IN ADULTS

TO DIARRHEA IN INFANTS
*ESTIMATED VALUE FOR THE SPRING WATER AND SEDIMENT INCIDENTAL INGESTION $=0.2 \mathrm{mg} / \mathrm{kg}$-day

NOTE: SEVERE DIARRHEA COULD RESULT FROM ABOUT $4 \%$ OF THE PREDICTED EXPOSURES.

SEVERE TOXICITY - PERSISTENT DIARRHEA

IN INFANTS LEADING TO DEHYDRATION

FIGURE 6.1

HEALTH EFFECTS OF POTENTIAL SULFATE EXPOSURE RANGES FOR INFANTS NATURITA, COLORADO, SITE 
In addition to sulfate-induced diarrhea, vanadium alone could also cause diarrhea and intestinal cramps. More than 90 percent of the predicted range of children exposures to vanadium could be associated with intestinal cramps and diarrhea (Figure 6.2).

Infants exposed to vanadium from the drinking water ingestion route could have about 5 times the exposures of children. Therefore, expected vanadium toxicity could be more serious in infants than in children. Simultaneous exposure to vanadium and sulfate in drinking water could augment the severity of sulfateinduced diarrhea.

Drinking ground water would lead to acute toxicity in infants, children, and adults due to sulfate levels, which could preclude chronic exposures. However, because different ground water contaminants flush out at different rates and because remedial action strategies may differ for different contaminants, the effects from long-term exposures to contaminants other than sulfate are also discussed.

The entire exposure distribution for manganese (Figure 6.3) is above the threshold levels of mild neurological symptoms including memory loss, irritability, muscle rigidity, and above the EPA RfD derived from drinking water consumption studies. About 6 percent of the exposure distribution is above the threshold for Parkinson-like disease. As discussed in Section 5.1.3 and earlier in this section, infants may be more susceptible to manganese toxicity than children and adults. Therefore, toxic effects may appear in infants at levels lower than those in children.

Although only 4 percent of sodium chronic exposures exceeds the upper end of sodium normal dietary intake levels, 60 percent of the exposure distribution is above the threshold level of hypertension in sensitive humans (Figure 6.4). Therefore, the development of hypertension would be expected in children and sensitive adults from the majority of sodium exposures. In addition, sustained ingestion of chloride present at levels observed in the most contaminated ground water may contribute to the development of hypertension in sensitive individuals, although some uncertainty is associated with literature data (NRC, 1989). Diarrhea caused by sulfate and other preexisting illnesses such as renal insufficiency or liver disease could augment this health effect.

About 75 percent of chronic molybdenum intake distribution from contaminated ground water falls above the acceptable intake level recommended by the EPA (RfD of $0.005 \mathrm{mg} / \mathrm{kg}$-day) (Figure 6.5). About 50 percent of the exposure range could be associated with mild toxicity resulting from copper loss from the body and possibly manifested as copper deficiency anemia and increased production of uric acid, if ground water were ingested for long periods of time.

With regard to noncarcinogenic effects (carcinogenic effects will be discussed in Section 6.2), the entire exposure distributions for uranium and arsenic fall within the NOAEL range (Figures 6.6 and 6.7 ), and only about 30 percent of arsenic 


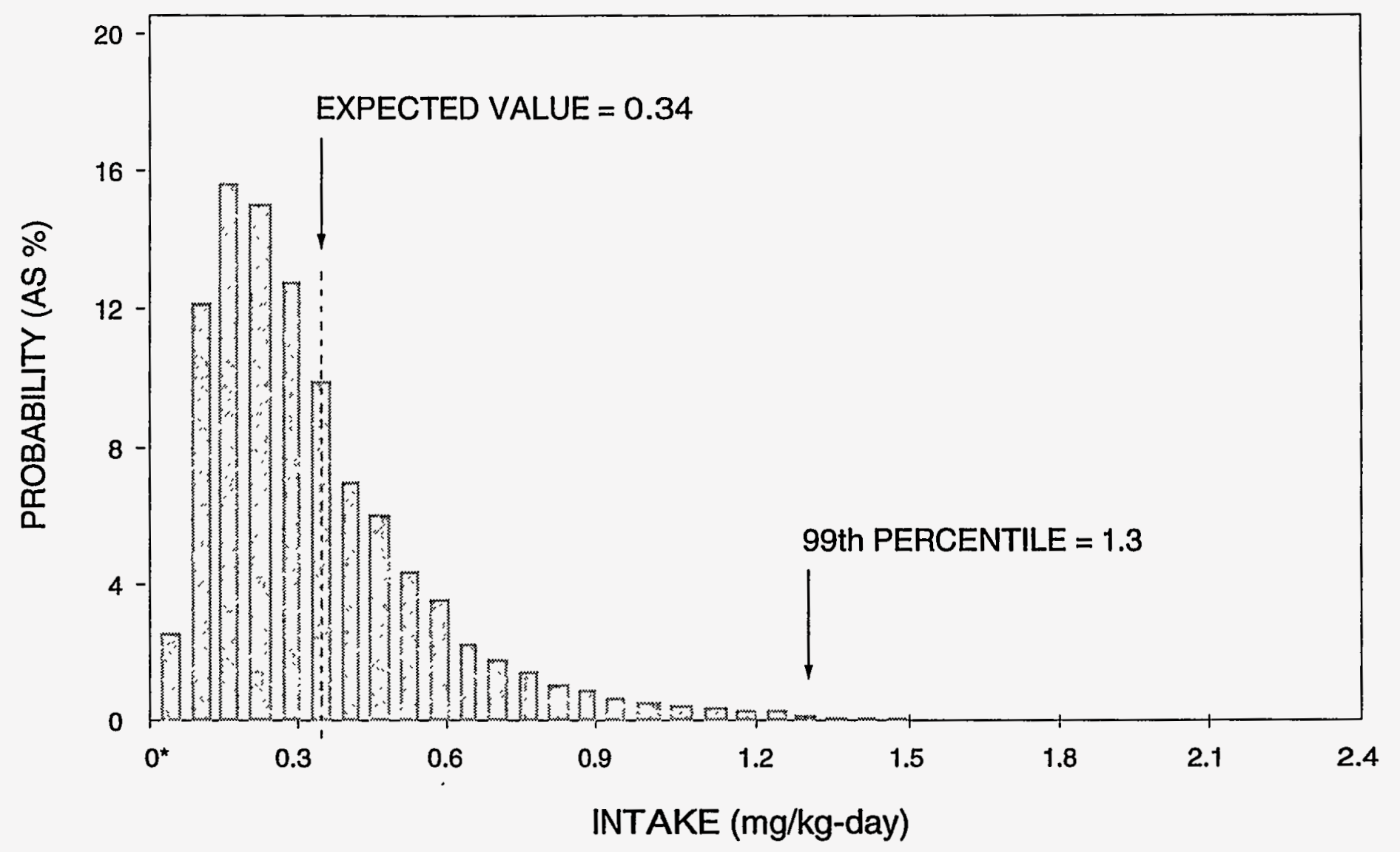

I DIETARY INTAKE

* ESTIMATED VALUE FOR THE SPRING WATER AND SEDIMENT INCIDENTAL INGESTION $=0.00002 \mathrm{mg} / \mathrm{kg}$-day

A ORAL RfD (0.007 mg/kg-day)

NOTE: MILD TOXICITY MANIFESTED AS INTESTINAL CRAMPS AND DIARRHEA COULD RESULT FROM ALL BUT ABOUT 6\% OF IMPAIRED CONDITIONED REFLEXES (RATS)

THE PREDICTED RANGE OF EXPOSURES.

INTESTINAL CRAMPS, DIARRHEA, GREEN TONGUE

FIGURE 6.2

HEALTH EFFECTS OF POTENTIAL VANADIUM EXPOSURE RANGES FOR CHILDREN NATURITA, COLORADO, SITE 


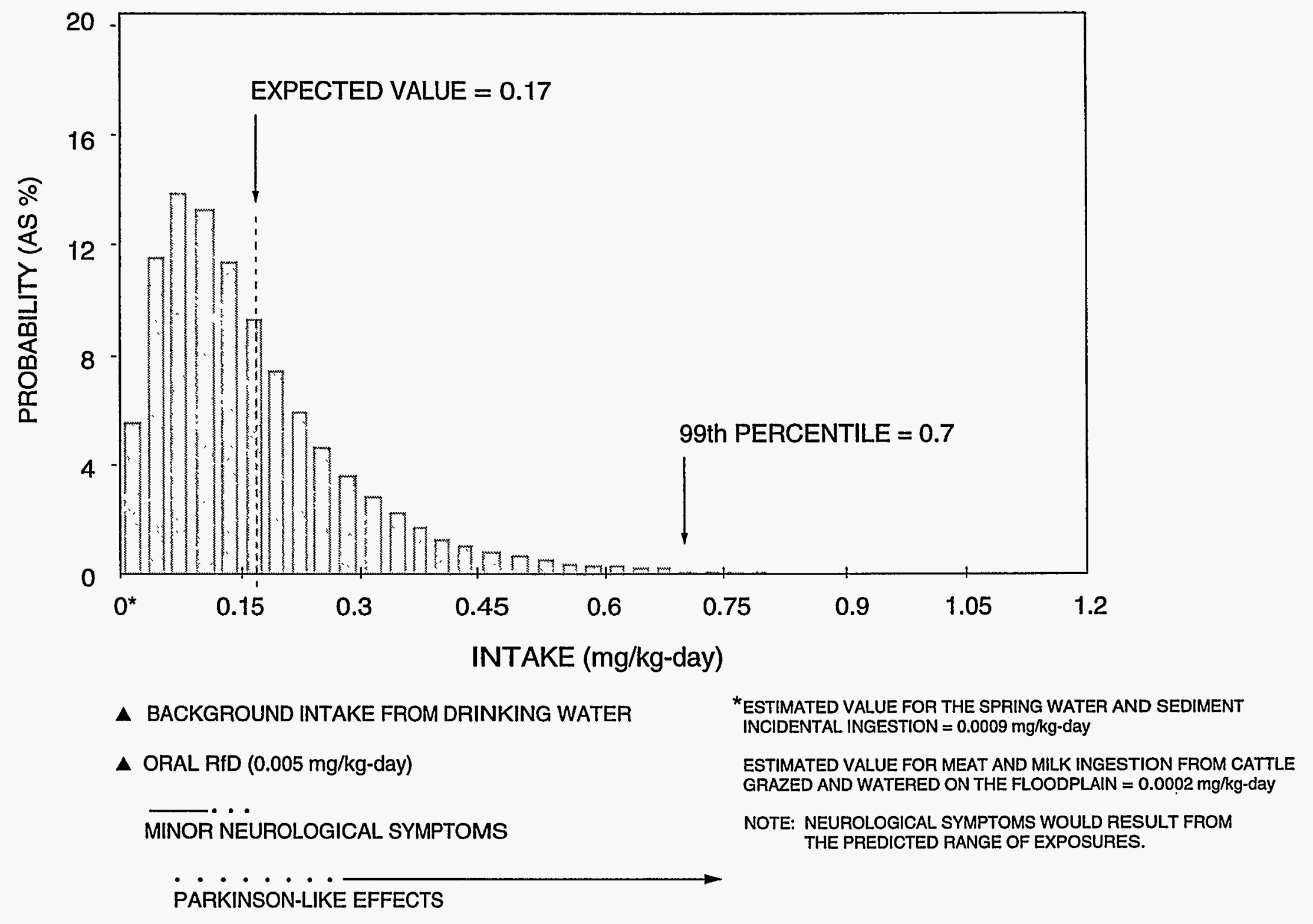

FIGURE 6.3

HEALTH EFFECTS OF POTENTIAL MANGANESE EXPOSURE RANGES FOR CHILDREN NATURITA, COLORADO, SITE 


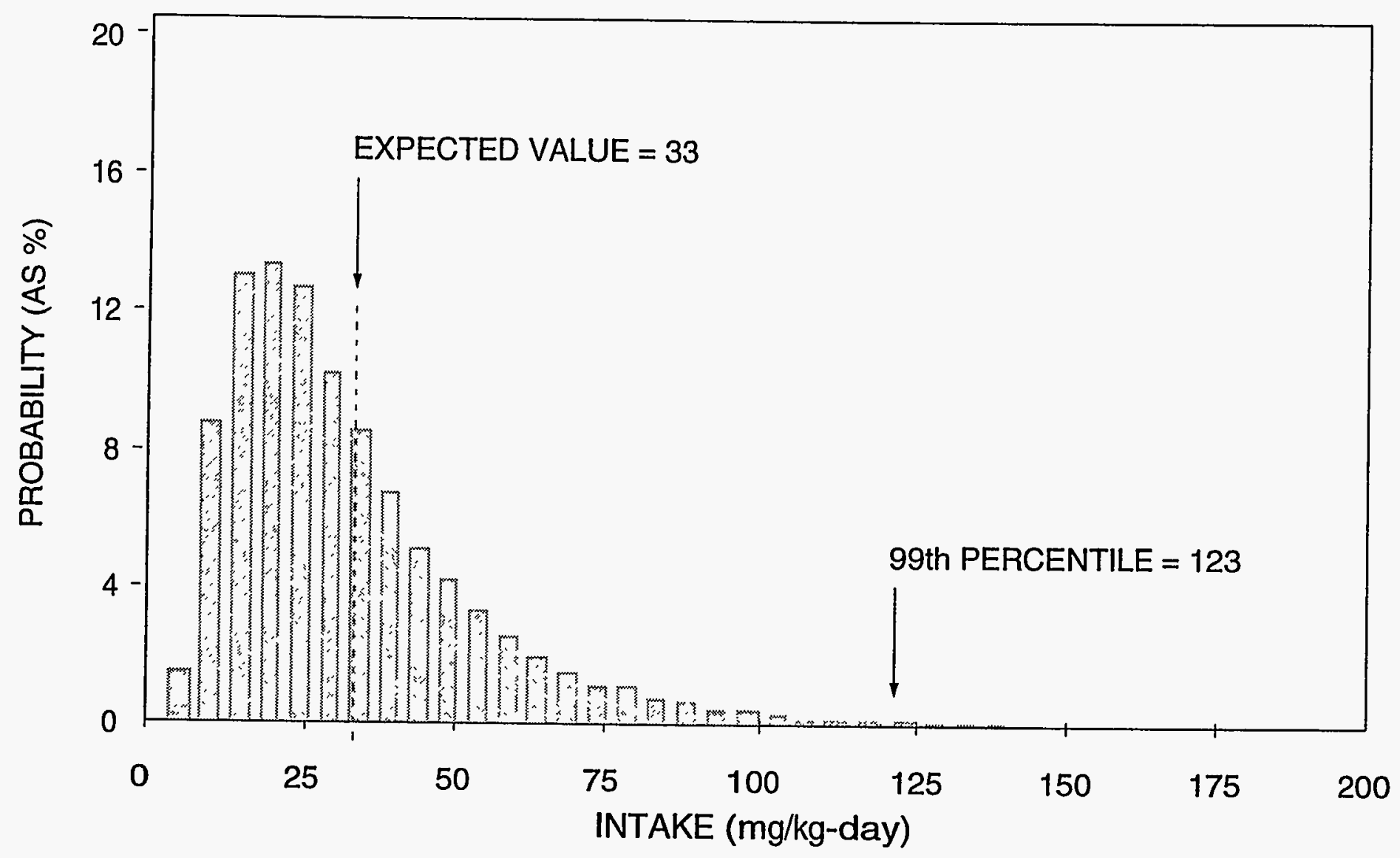

BACKGROUND INTAKE LEVELS FROM DRINKING WATER

- NUTRITIONAL REQUIREMENT

NOTE: HYPERTENSION COULD RESULT IN SENSITIVE INDIVIDUALS FROM ABOUT 60\% OF THE PREDICTED RANGE OF EXPOSURES.

$\triangle$ NRC-RECOMMENDED UPPER LIMIT FOR DIETARY INTAKE

DIETARY INTAKE LEVELS

HYPERTENSION MAY OCCUR IN HUMANS

FIGURE 6.4

HEALTH EFFECTS OF POTENTIAL SODIUM EXPOSURE RANGES FOR CHILDREN NATURITA, COLORADO, SITE 

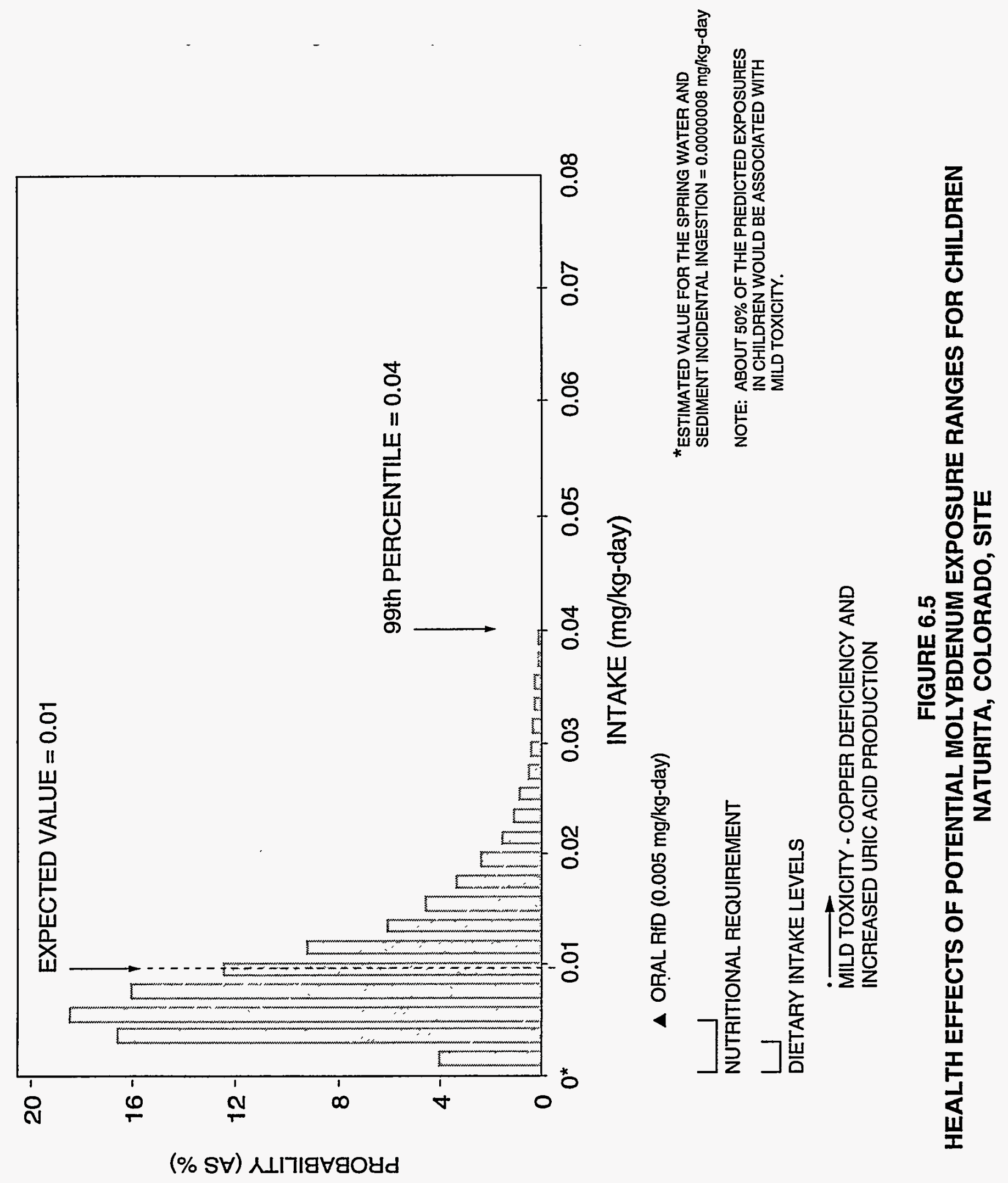


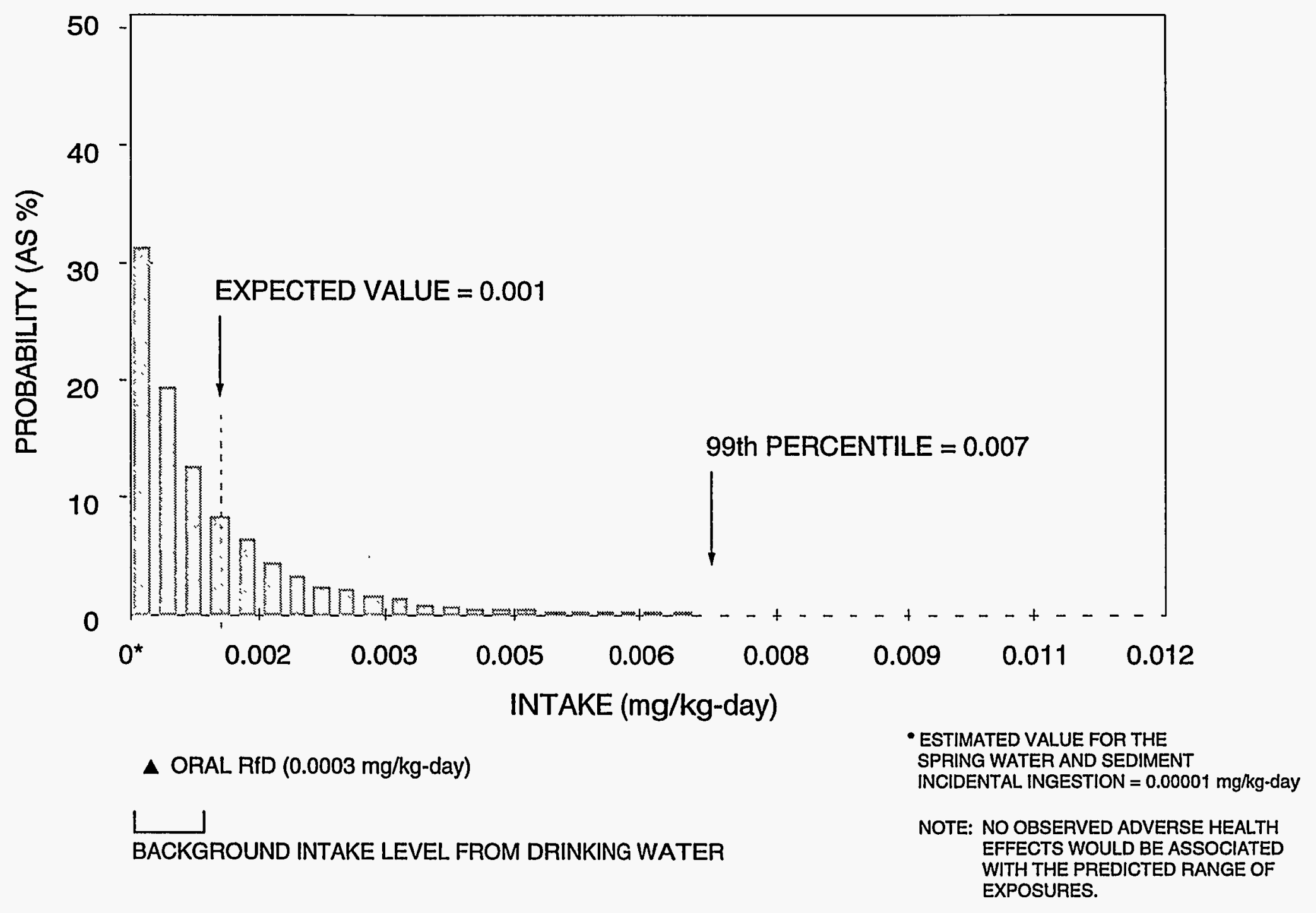

FIGURE 6.7

HEALTH EFFECTS OF POTENTIAL ARSENIC EXPOSURE RANGES FOR CHILDREN NATURITA, COLORADO, SITE 
intake distribution exceeds the upper end of background arsenic intake range from drinking water (Figure 6.7). However, almost 100 percent of the exposure distribution for uranium and about 70 percent of that for arsenic is above the EPA acceptable intake level (RfD of $0.003 \mathrm{mg} / \mathrm{kg}$-day for uranium and RfD of $0.0003 \mathrm{mg} / \mathrm{kg}$-day for arsenic). Note that diabetics and the elderly may be more sensitive to uranium toxic effects on the kidney than healthy individuals (see also Section 5.1.9). Arsenic and selenium together may reduce their respective toxicities; however, some methylated metabolites of selenium can increase arsenic toxicity.

Although about 17 percent of the antimony exposures (Figure 6.8) exceed the EPA oral RfD (RfD of $0.0004 \mathrm{mg} / \mathrm{kg}$-day), these intake levels fall below the lower end of dietary intake range and are well below any level associated with adverse health effects (see Section 5.1.1).

These apparent discrepancies seen between the EPA acceptable intake levels (RfDs) and the intake levels of arsenic, uranium, and antimony reported in literature to be associated with adverse health effects occur largely because the toxicological database is incomplete. EPA takes this uncertainty into account by lowering the acceptable intake levels. Although these low intake levels of arsenic, uranium, and antimony have not been associated with adverse health effects in humans or test animals, it is important that a portion of the exposure distributions fall above the RfD criterion.

Finally, all but about 3 percent of selenium intake distribution falls within the dietary intake range and the entire exposure distribution is within the NOAEL (Figure 6.9). An insignificant portion of these intake levels (less than 1 percent) exceeds the EPA acceptable intake level (RfD of $0.005 \mathrm{mg} / \mathrm{kg}$-day).

The potential exposure contribution from other pathways, including produce ingestion or meat and milk ingestion, could not be estimated with current data. The UMTRA Project is conducting additional studies, and the results will be used to better characterize these pathways. Although drinking water ingestion is believed to result in the greatest exposure and therefore toxicity, these pathways may contribute considerably to overall exposure.

\subsubsection{Floodplain spring water potential use}

Potential health effects were evaluated for older children (aged 9 to 10 years) who might be exposed to contaminants while playing on the floodplain. Antimony, arsenic, manganese, molybdenum, sulfate, uranium, and vanadium were detected in surface water body at the spring location on the floodplain. As can be seen in Figures 6.1 through 6.3 and 6.5 through 6.8 , no adverse health effects would be expected from incidental exposures (such as incidental ingestion of sediments and surface water) estimated for this subpopulation. Also, where applicable, estimated exposure levels for each of the contaminants of potential concern are well below corresponding the EPA acceptable intake level. 


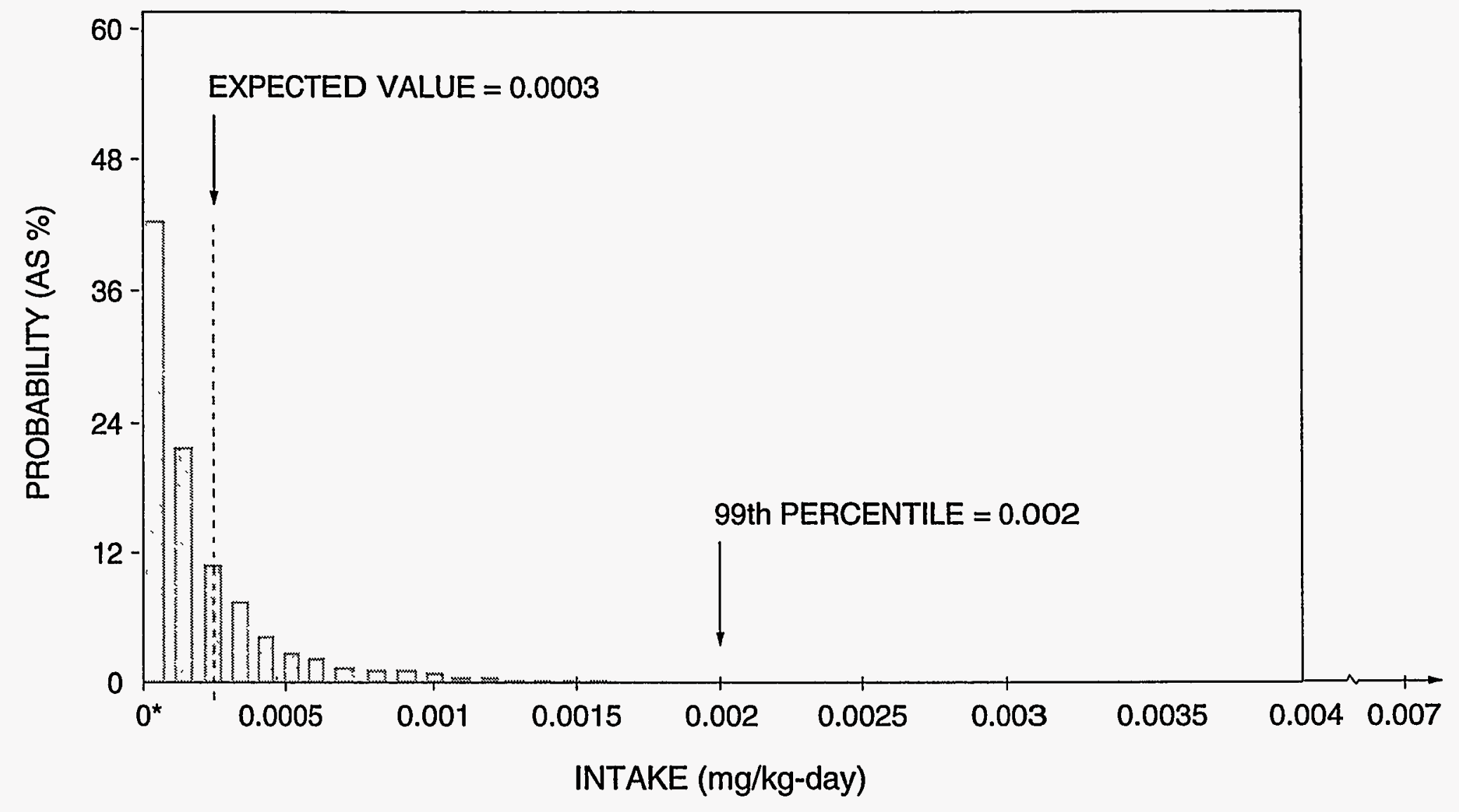

A ORAL RfD (0.0004 mg/kg-day)

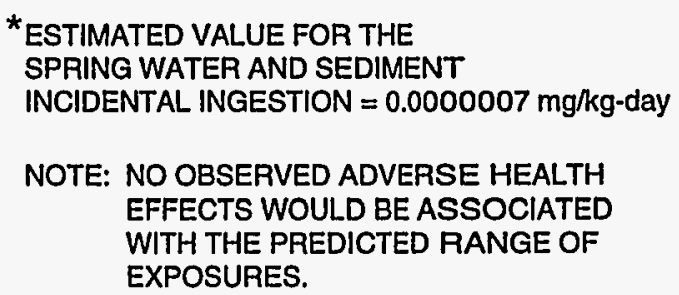



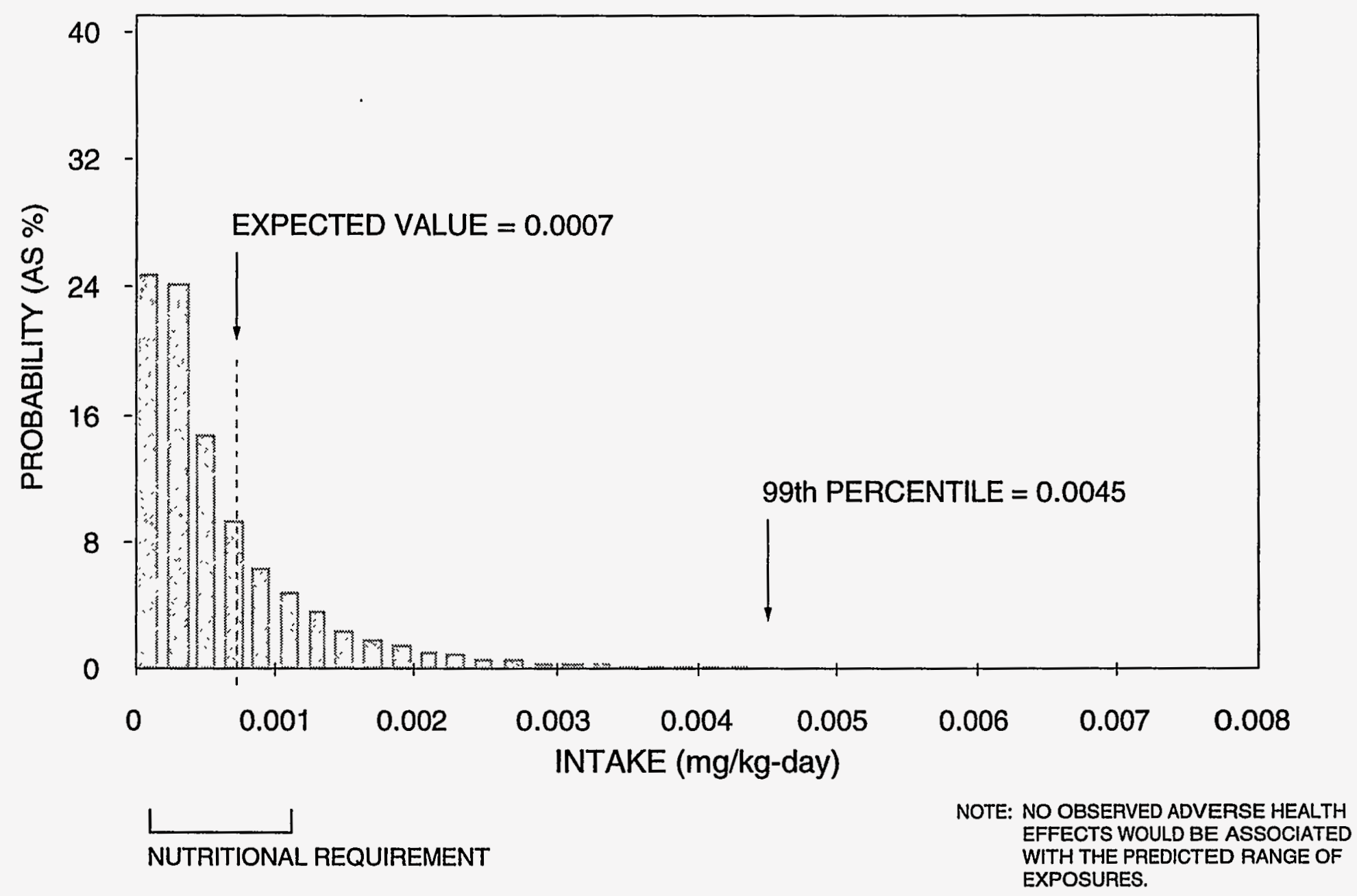
EFFECTS WOULD BE ASSOCIATED WITH THE PREDICTED RANGE OF EXPOSURES.

NUTRITIONAL REQUIREMENT

DIETARY INTAKE LEVELS

A ORAL RfD $(0.005 \mathrm{mg} / \mathrm{kg}$-day $)$

NO OBSERVED EFFECT LEVEL

FIGURE 6.9

HEALTH EFFECTS OF POTENTIAL SELENIUM EXPOSURE RANGES FOR CHILDREN

NATURITA, COLORADO, SITE 
Likewise, chronic exposure to manganese (Figure 6.3 ) by consuming meat and milk from cattle grazed and watered on the floodplain at or near the spring is not expected to cause adverse health effects in humans.

\subsection{POTENTIAL CARCINOGENIC HEALTH EFFECTS}

All uranium isotopes are radioactive and, as such, are considered carcinogens. Also, radium-228, which is the product of natural thorium-232 radioactive decay is considered a carcinogen. Table 6.1 shows estimated excess lifetime cancer risks resulting from potential ingestion of ground water contaminated with uranium-234/238, longer-lived radioactive progeny of the uranium decay series (lead-210, polonium-210, radium-226, and thorium-230), and radium-228. These estimates are based on the cancer slope factors developed by the EPA (EPA, 1994b); however, natural uranium has not been demonstrated to cause cancer in humans or animals following ingestion exposures. The potential exposure values result in a overall excess lifetime cancer risk of about 4 in 1,000. This exceeds the EPA's National Contingency Plan (NCP) guidance (developed for Superfund sites), of a maximum increased cancer risk of 1 in 10,000 .

If contaminated ground water at the Naturita site were used as drinking water, the risk of skin cancer could increase as a result of lifetime exposure to detected arsenic levels (Table 6.1). This evaluation is based on the EPA oral slope factor of $1.8(\mathrm{mg} / \mathrm{kg} \text {-day) })^{-1}$ for skin cancer development. The estimated arsenic exposure value could result in an excess lifetime cancer risk of about 2 in 1,000 .

The cancer risk estimates presented here are thought to be conservative because they are based on the worst case (highest level) concentrations and a cumulative lifetime (50-year) exposure duration. However, few people (if any) would spend their lifetime near the Naturita site. In addition, ground water concentrations may decline over this time because the Naturita site will be cleaned up.

\subsection{LIMITATIONS OF HUMAN RISK EVALUATION}

The following potential limitations should be kept in mind when interpreting this risk evaluation.

- Populations with potentially increased sensitivity, such as the elderly or individuals with preexisting diseases, were not specifically addressed on the toxicity ranges presented in the graphs. Expected sensitivities in certain groups were discussed in the text to the extent possible.

- Some individuals may be more sensitive to the toxic effects of certain constituents for reasons that have not been determined. Therefore, adverse health effects may occur at lower exposure levels in sensitive individuals. 
Table 6.1 Calculation of excess lifetime cancer risks from ingestion of ground water, Naturita, Colorado, site

\begin{tabular}{|c|c|c|c|c|}
\hline $\begin{array}{l}\text { Contaminant of } \\
\text { potential concern }\end{array}$ & $\begin{array}{c}\text { Exposure } \\
\text { concentration } \\
\text { (pCi/L) }\end{array}$ & $\begin{array}{c}\text { Exposure dose }^{b} \\
\text { (pCi/lifetime) }\end{array}$ & $\begin{array}{l}\text { Oral slope factor } \\
\qquad(p \mathrm{C} i)^{-1}\end{array}$ & Cancer risk $^{d}$ \\
\hline $\begin{array}{l}\text { Chemicals } \\
\text { Arsenic }\end{array}$ & $0.054^{\circ}$ & $1.1 \mathrm{E}-03^{f}$ & $1.8 E+00^{f}$ & $2 \mathrm{E}-03$ \\
\hline $\begin{array}{l}\text { Radionuclides } \\
\text { Lead-210 } \\
\text { Polonium-210 } \\
\text { Radium-226 } \\
\text { Radium-228 } \\
\text { Thorium-230 } \\
\text { Uranium-234 } \\
\text { Uranium-238 }\end{array}$ & $\begin{array}{l}13.5^{\mathfrak{g}} \\
4.5^{9} \\
7.6 \\
4.8 \\
0.9^{\mathfrak{g}} \\
823 \\
823\end{array}$ & $\begin{array}{l}4.7 E+05 \\
1.6 E+05 \\
2.7 E+05 \\
1.7 E+05 \\
3.2 E+04 \\
2.9 E+07 \\
2.9 E+07\end{array}$ & $\begin{array}{l}1.01 \mathrm{E}-09 \\
3.26 \mathrm{E}-10 \\
2.96 \mathrm{E}-10 \\
2.48 \mathrm{E}-10 \\
3.75 \mathrm{E}-11 \\
4.44 \mathrm{E}-11 \\
6.20 \mathrm{E}-11\end{array}$ & $\begin{array}{l}5 E-04 \\
5 E-05 \\
8 E-05 \\
4 E-05 \\
1 E-06 \\
1 E-03 \\
2 E-03\end{array}$ \\
\hline Total radionuclides: & & & & $4 E-03$ \\
\hline \multicolumn{5}{|c|}{$\begin{array}{l}\text { The exposure concentration is represented by the upper } 95 \text { percent confidence interval } \\
\text { for mean contaminant concentration in ground water. } \\
\text { b Calculated using equations }(2) \text { and }(3) \text { in Section } 4.4 \text { for arsenic and radionuclides, } \\
\text { respectively, and the following exposure assumptions: contaminant concentrations in } \\
\text { ground water are represented by the } 95 \% \text { confidence interval for mean unless otherwise } \\
\text { specified; the ingestion rate }=2 \mathrm{~L} \text { of water/day; the exposure frequency }=350 \text { days/year; the } \\
\text { exposure duration }=50 \text { years; body weight }=70 \mathrm{~kg} \text {. } \\
\text { 'The basis for these oral slope factors is presented in Table } 5.1 \text {. } \\
\text { d Cancer risk = exposure dose } x \text { slope factor. } \\
\text { Units are milligrams per liter. } \\
\text { 'Units are milligrams per kilogram per day. } \\
\text { 'The exposure concentration is represented by maximum observed contaminant concentration. } \\
\text { "The upper } 95 \text { percent confidence limit for the mean of uranium concentration in ground water is } \\
2.4 \text { milligrams per liter; } 1 \text { milligram uranium is assumed to equal } 686 \text { picocuries; the secular } \\
\text { equilibrium between U-234 and }-238 \text { is assumed to estimate activity of different radioisotopes of } \\
\text { uranium. }\end{array}$} \\
\hline
\end{tabular}


- Available data on potential adverse health effects may not always be sufficient to accurately determine all health effects because human data are not sufficient or exposure ranges differed from exposures expected at this site.

- Although contaminated ground water areal extent and movement have been evaluated hydrologically and geochemically, it is possible that the monitoring locations sampled were not in the most contaminated portion of the ground water. Additionally, constituent concentrations will decrease as the contaminated ground water moves.

- The risk evaluation results presented in this document are based on filtered $(0.45-\mu \mathrm{m})$ ground water samples. Therefore, the potential loss of certain ground water constituents as a consequence of filtration is associated with a source of uncertainty.

- Only the drinking water ingestion pathway was considered in depth, and the dermal absorption pathway was screened out. However, the incremental contribution from the ground water-irrigated produce and meat or milk ingestion pathways, which could not be estimated here, should also be considered.

The evaluation presented here has considered these limitations and compensated whenever possible by presenting toxicity ranges and probabilistic exposure assessments rather than point estimates to incorporate as much variability as could be reasonably defined. The impact of these potential limitations is discussed more fully in Section 8.2. 


\subsection{ECOLOGICAL AND LIVESTOCK RISK EVALUATION}

The objective of this section is to assess the potential for site-related contaminants to adversely affect existing biological communities, livestock grazing, and other agricultural practices in the Naturita site area. Currently, the EPA has no guidance for quantifying potential ecological impacts of the release of hazardous constituents. The EPA has, however, developed a qualitative approach to be used in ecological risk evaluations (EPA, 1989b). As part of this qualitative approach, the EPA recommends that ecological assessments be conducted in a phased approach, which makes the most effective use of resources while ensuring that all necessary work is conducted (EPA, 1992c). This approach consists of four increasingly complex phases: identifying potentially exposed habitats, collecting chemistry data, collecting biological samples, and conducting toxicity testing. If the initial habitat inspection and the media sample analysis indicate little or no potential for ecological risk, the assessment will likely be complete. If the early phases of the assessment indicate that the contaminants may be adversely affecting ecological receptors, a higher level of analysis may be warranted.

Because habitats at the Naturita site may have been affected, and because water chemistry data collected for several years are available, the ecological risk assessment implements the first two phases of EPA's approach. Existing water quality, sediment, and vegetation data were used to prepare this assessment. This qualitative approach provides a screening-level assessment of the risks associated with potential exposure to contaminated media at the Naturita site.

It is often difficult to determine whether contaminants have affected the biological component of an ecosystem and to predict whether observed effects will damage the ecosystem. Samples of environmental media, such as surface water, can be used to assess the possibility of ecological risk. For an ecological risk to occur, there must be both a source of contamination and a pathway for this contamination to reach the biological communities. The remaining sections of this ecological assessment identify the following:

- Areas of contamination and the potential pathways by which this contamination may be entering the aquatic and terrestrial biological communities at the Naturita site.

- Potential ecological receptors at the Naturita site.

- Contaminants of potential concern.

- Potential hazards the contaminants of concern may pose to the ecological resources, livestock, and agricultural crops.

\subsection{EXPOSURE PATHWAYS}

The designated Naturita site covers 53 ac (21 ha), much of which is the floodplain of the San Miguel River. See Sections 2.1 and 2.6 for a more detailed description of the Naturita site. 
The alluvial aquifer was contaminated beneath the Naturita site during and after the operation of the uranium processing facility. Section 3.0 summarizes the degree and extent of this ground water contamination. A potential pathway for this contamination to reach the environment is via deep-rooted plants transporting contaminants to the surface directly out of this alluvial aquifer. Although the contaminated ground water is entering the San Miguel River, siterelated contaminants have not been detected above background levels in the surface water and sediments, nor would they be expected, based on the worstcase scenario (low river flow) calculations discussed earlier (Section 3.6). Therefore, the river is not considered an exposure point for environmental receptors. Contaminated ground water has entered a small spring-fed pond near the river. Therefore, this pond represents an exposure point for environmental receptors.

A potential future exposure pathway that does not now exist at the Naturita site is the installation of a well in a contaminated aquifer to create a stock pond and/or irrigate crops. A contaminated stock pond could affect livestock or wildlife that drink the water as well as aquatic organisms, including fish, that could inhabit the pond. Humans and wildlife could also ingest contaminants by eating crops irrigated with contaminated ground water.

\subsection{ECOLOGICAL RECEPTORS}

This section describes the terrestrial and aquatic resources present at and near the Naturita site and is based on information collected during field surveys at the Naturita site. Since 1986, ecological surveys have been conducted almost every year at the Naturita site (TAC, 1994a; 1994b; 1992; 1991; 1990; 1988; and 1986). These surveys were principally conducted to determine terrestrial ecological resources at the Naturita site, with an emphasis on describing riparian plant communities and associated wildlife along the San Miguel River and conducting surveys for the endangered southwestern willow flycatcher. One field trip was conducted to collect water, sediment, and vegetation samples and to collect qualitative information on the river's qualitative aquatic resources (TAC, 1994a).

This assessment provides a summary description of the riparian plant communities, threatened and endangered species, and other ecological resources at the Naturita site. More details regarding these resources is provided in the Naturita environmental assessment (EA) (DOE, 1994C).

\subsubsection{Terrestrial resources}

Three types of vegetation grow at and near the Naturita site: riparian, upland desert shrub, and mostly bare ground with early successional plant species in disturbed areas (Figure 7.1). The riparian areas occupy narrow bands along reaches of the river that are flanked by steep hillsides and broader expanses of relatively level ground where the river flows away from the hillsides. The 
vegetation in the narrow bands grows in three distinct zones. The zone closest to the river is the cottonwood/willow seedling plant community and consists of rocky bars that are flooded frequently. The cottonwood/willow sapling zone typically occurs on terraces above the river and is dominated by dense growths of cottonwood saplings and willow. The upper zone is dominated by mature cottonwoods that typically grow up to the base of the hillsides and mark the beginning of the upland plant communities.

The plant communities in the broader expanses of the riparian areas are an interspersion of various types (Figure 7.1). Low-lying areas are dominated by willow. Drier ground is typically covered by cottonwood stands of various ages, with willow and other woody species in the understory and a ground cover of grass and herbs. Still drier areas are covered by the upper riparian shrub plant community, with willow and squawbush and more upland plant species such as rabbitbrush and big sagebrush being common.

The upland desert shrub plant community occurs in small elevated areas along the river between the pockets of riparian vegetation. Common shrub species observed are greasewood, big sagebrush, squawbush, rabbitbrush, saltbush, yucca, prickly pear cactus, and Mormon tea.

Land areas have been disturbed in the former mill yard and former tailings pile area. Much of the former mill yard is flat, hard-packed gravel with little, if any, soil. As a result, there is much bare ground with very widely dispersed, early successional species such as Russian thistle and white sweet clover. The eastern part of the former tailings pile area is rocky and largely devoid of vegetation. A dense growth of cottonwood saplings and young willows and salt cedars has developed in the western half of this area.

Sixty-four species of nesting birds have been observed in the Naturita site area. Three nesting bird censuses were conducted over a 6 -year period. The yellow warbler is the most common species in the riparian habitat types. The spotted sandpiper was also common and was most often seen along the river. The great blue heron and belted kingfisher were occasionally seen fishing in the river but are not known to nest in the Naturita site area. Mallards, alone or in pairs, have been observed. Nest sites for birds of prey have not been observed along the river, but the prairie falcon and golden eagle could use the area for foraging. Large numbers (up to 22) of turkey vultures have been roosting for a number of years in a stand of mature cottonwoods across the river from the Naturita site.

At least 19 species of mammals may occur in the riparian habitat along the San Miguel River. In 1986, small beaver dams had been constructed in the drainages that run through the dense growth of cottonwoods in the former tailings pile area. Observations in 1988 revealed very little fresh beaver sign. Mule deer were observed along the river, and their sign (droppings) was common. This area is likely a mule deer winter range but not a critical winter range. There are also year-round resident deer in the area. 


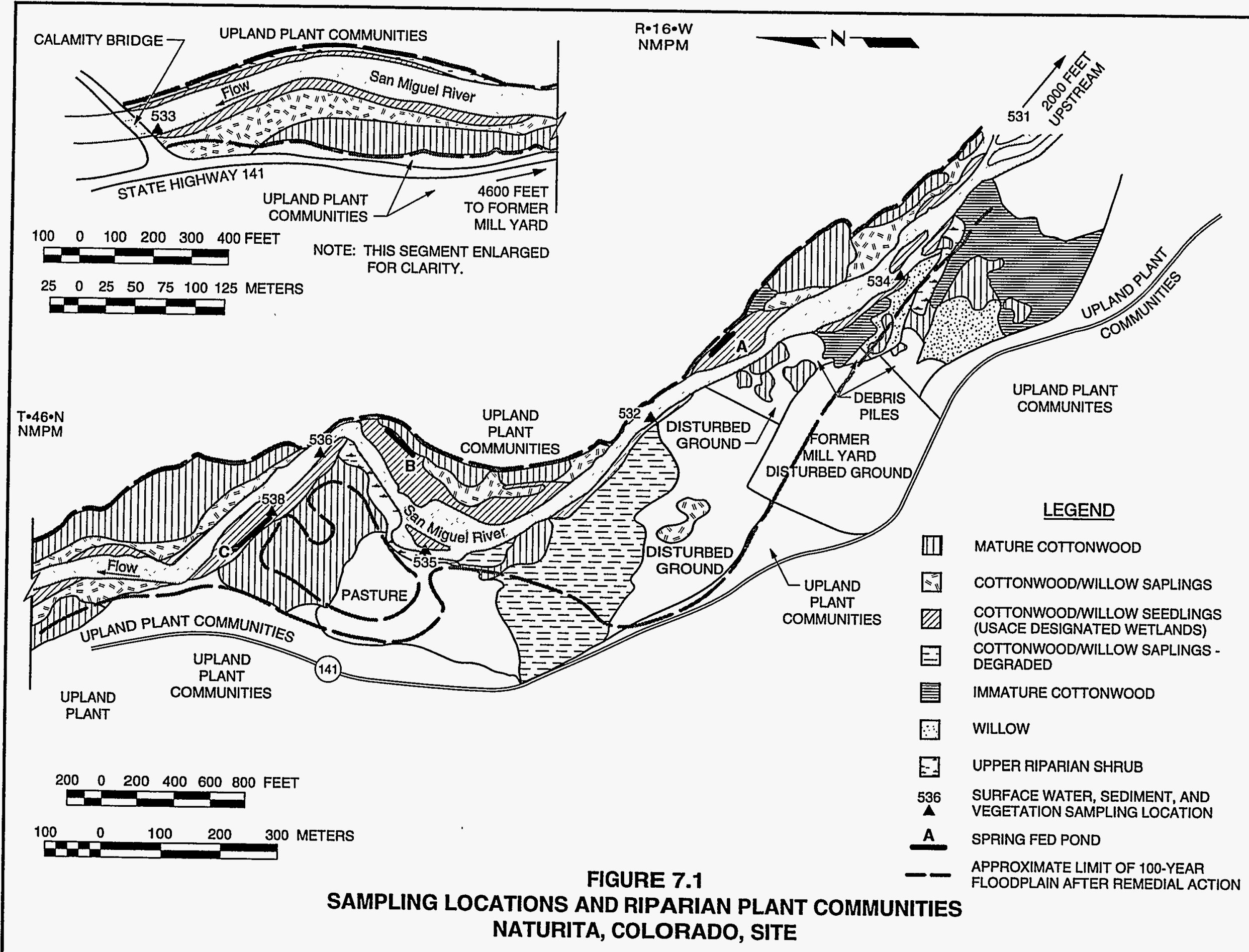




\subsubsection{Aquatic resources}

Aquatic resources in the Naturita site area consist of the San Miguel River and spring-fed wetlands and ponds in the floodplain of the San Miguel River (Figure 7.1).

\section{San Miguel River}

The San Miguel River originates in the San Juan Mountains near Telluride, Colorado, and joins the Dolores River $20 \mathrm{mi}(32 \mathrm{~km})$ downstream from the town of Naturita. Approximately 31 ac (13 ha) of the former tailings and former mill yard areas are within the 100-year floodplain of the San Miguel River. Limited fish sampling in the San Miguel River (Table 7.1) resulted in six species being recorded (CDOW, 1977). The flannelmouth sucker and rainbow trout were the most common species collected. The following qualitative information was collected regarding aquatic life at each river sampling location (TAC, 1994a); see Figure 7.1 for sampling locations.

Table 7.1 Fish species recorded in the San Miguel River at the Naturita, Colorado, site

\begin{tabular}{ll}
\hline \multicolumn{1}{c}{ Scientific name } & \multicolumn{1}{c}{ Common name } \\
\hline Salmo giarderneri & rainbow trout \\
Salmo clarki & cutthroat trout \\
Rhinichthys osculus & speckled dace \\
Catostomus discobolus & bluehead sucker \\
Catostomus latipinnis & flannelmouth sucker \\
Cottus bairdi & mottled sculpin \\
\hline
\end{tabular}

From CDOW (1977).

Qualitative information regarding aquatic life in the San Miguel River was collected at site sampling locations in 1994 (TAC, 1994b) (see Figure 7.1 for sampling locations). The river bottom was similar at all locations and consisted of 4 to 12 in $(10$ to $30 \mathrm{~cm}$ ) diameter rock covered with silt. Snails, dipteran, and chrinomid worms were abundant. Sensitive benthos (Ephemeoptera, Plecoptera, and Trichoptera) including caddisfy larvae in stone cases, mayfly and stonefly nymphs were observed at some locations.

\section{Spring fed ponds}

Two ponds ( $A$ and $B$ ), believed to be recharged by the alluvial aquifer, a spring (538), at times forming a pond (C), and their associated wetlands occur in the floodplain of the San Miguel River at the Naturita site (see Figure 7.1). They occur in old meander channels of the river and are likely flooded during periods of high flow. During most of the year they are cut-off from the river and yet hold water. 
Ponds $A$ and $B$ are on the northeast side of the river across from the Naturita site. Both ponds contain aquatic plants such as cattail, Juncus sp., Carex sp., bullrush, and a dense growth of spikerush were observed. No observation for aquatic invertebrates was made (TAC, 1992; 1994b).

Pond $C$ is on the south side of the river downgradient from the Naturita site. Surface water, sediment, and vegetation samples were collected at sampling location 538 in November 1994. This location is about $120 \mathrm{ft}(37 \mathrm{~m})$ south of the river in an area of standing water; there was a small amount of water flowing out of this area to the river. Pond $C$ is spring fed. During sampling (16 November 1994), it was noted that the water temperature was noticeably warmer than the San Miguel River water. This body of water was approximately 5 to $15 \mathrm{ft}(2$ to $4.6 \mathrm{~m})$ wide and about $250 \mathrm{ft}(76 \mathrm{~m})$ long and about $4 \mathrm{ft}(1 \mathrm{~m})$ deep in some parts. A couple patches of cattail were observed; Carex sp., rabbitsfoot grass, and spikerush were also seen. The most common aquatic plant was an unidentified submergent broad-leafed species. The water was clear in most of this pond. A film was observed at the southeast end of pond $\mathrm{C}$, and a dense growth of brown and green filamentous algae and ironcolored deposits were on the bottom in this area. Sampling occurred at this location of the pond. Several damselfly nymphs, a few amphipods, waterboatmen, and backswimmers were seen at the west end of this pond. Spiders were seen on the surface throughout.

\subsubsection{Threatened and endangered species}

This section describes the status of the threatened and endangered species and other species of concern that may occur in the study area; threatened and endangered species are addressed in detail in the Naturita site biological assessment, which is attached to the EA (DOE, 1994c). The following is a summary of that more detailed discussion.

\section{Bald Eagle}

The bald eagle is an endangered species and is generally associated with river habitat where suitable perches and viable fisheries are available; large cottonwood trees are used for perching or roosting sites. The bald eagle is not known to nest along the San Miguel River but does hunt along the river during the winter. Although bald eagles have been seen perched in the cottonwoods in the riparian habitat, there are no known, regularly used roost sites along the river in the area of the Naturita site. The bald eagle density is generally low (approximately six) along the river in the Naturita site area, and use in the upland Naturita site areas is sporadic (Welch, 1993; Sherman, 1987; Carruthers, 1986).

\section{Southwestern willow flycatcher}

The southwestern willow flycatcher is an endangered species. This species generally nests in willows; in recent years it has started nesting in salt cedars. 
The preferred habitat is riparian habitat along bodies of water, such as that which occurs along the San Miguel River (Unit, 1987). In 1986, two male willow flycatchers (subspecies not determined) were heard calling repeatedly in the dense cottonwoods and willows growing in the western part of the former tailings pile area (TAC, 1986). Additional field surveys were conducted for this species in June of 1990, 1991, 1993, and 1994 (TAC, 1994a; 1993; 1991; 1990). It was not heard or observed in the area of the Naturita site. Based on these surveys, it was determined that the willow flycatcher does not currently nest along the San Miguel River near the Naturita site.

\section{Endangered and candidate fish}

The historical range of the endangered Colorado squawfish, boneytail chub, humpback chub, and razorback sucker included the Colorado River and all of the larger tributaries, such as the San Miguel River. Currently, these fish species do not occur in the San Miguel River (Carruthers, 1986).

7.3 CONTAMINANTS OF POTENTIAL ECOLOGICAL CONCERN AND ECOLOGICAL RISK

\subsubsection{San Miguel River}

As discussed in Section 3.6, there is no difference in water quality upstream and downstream from the Naturita site which indicates that the Naturita site activities do not have an effect on the San Miguel River water. One round of sediment samples has been analyzed from six locations along the San Miguel River (Figure 7.1). As discussed in Section 3.6, these limited data indicate no consistent difference in sediment quality from the upstream and downstream sampling locations (Table 3.6). One round of vegetation samples was collected from the same six locations along the San Miguel River. Spikerush was sampled from saturated substrate next to the river at all locations. Based on these limited data, there is no consistent difference in the levels of constituents upstream and downstream from the Naturita site (Table 7.2). Because only one round at samples has been collected, the sediment and plant data are viewed as preliminary.

Bioconcentration factors from sediments to plants were calculated for some of the constituents (Table 7.3). As can be seen in Table 7.3, plants did not bioconcentrate iron, manganese, strontium, or vanadium (the mean bioconcentration factor is about 1). However, they did bioconcentrate arsenic and uranium (the mean bioconcentration factor is 1.4 and 1.6, respectively).

\subsubsection{Other surface water bodies}

Of the spring fed ponds only pond $\mathrm{C}$ at location 538 was sampled.

The analysis of water quality data of the contaminated alluvial aquifer (Section 3.2) and the pond indicates that site related contaminants have reached this 
Table 7.2 Concentrations of constituent in plants collected in November 1994 from six locations in the San Miguel River at the Naturita, Colorado, site

\begin{tabular}{|c|c|c|c|c|c|c|}
\hline \multirow[b]{3}{*}{ Constituent } & \multicolumn{6}{|c|}{ Sample location } \\
\hline & \multicolumn{2}{|c|}{ Upstream } & \multicolumn{4}{|c|}{ Downstream } \\
\hline & Loc 531 & Loc 534 & Loc 532 & Loc 535 & Loc 536 & Loc 533 \\
\hline Antimony & 0.4 & 0.6 & 0.9 & 0.5 & 0.3 & $<0.3$ \\
\hline Arsenic & 7.8 & 7.8 & 9.9 & 7.7 & 7.4 & 3.8 \\
\hline Iron & 11,800 & 10,700 & 13,300 & 9,080 & 8,950 & 6,730 \\
\hline Manganese & 481 & 552 & 565 & 415 & 420 & 387 \\
\hline Molybdenum & 3 & 2 & 2 & $<1$ & 1 & 1 \\
\hline Selenium & 0.9 & $<0.5$ & $<0.5$ & $<0.5$ & 0.7 & 0.9 \\
\hline Silver & $<1$ & 1 & $<1$ & $<1$ & $<1$ & $<1$ \\
\hline Strontium & 134 & 115 & 109 & 149 & 175 & 128 \\
\hline Uranium & 5 & 3 & 4 & 7 & 8 & 7 \\
\hline Vanadium & 15 & 14 & 21 & 32 & 30 & 26 \\
\hline
\end{tabular}

Concentrations in milligrams per kilogram.

Table 7.3 Sediment to plant bioconcentration factors for six sampling locations along the San Miguel River near the Naturita, Colorado, site

\begin{tabular}{|c|c|c|c|c|c|c|c|}
\hline \multirow[b]{3}{*}{ Constituent } & \multicolumn{7}{|c|}{ Sampling location } \\
\hline & \multicolumn{2}{|c|}{ Upstream } & \multicolumn{5}{|c|}{ Downstream } \\
\hline & 531 & 534 & 532 & 535 & 536 & 533 & Mean \\
\hline Arsenic & 1.7 & 1.2 & 2.1 & 1.3 & 1.2 & 0.7 & 1.4 \\
\hline Iron & 1.0 & 0.8 & 1.0 & 0.8 & 0.7 & 0.6 & 0.8 \\
\hline Manganese & 1.3 & 1.0 & 1.6 & 1.2 & 0.7 & 1.0 & 1.1 \\
\hline Strontium & 1.0 & 0.6 & 0.8 & 1.0 & 0.8 & 0.9 & 0.9 \\
\hline Uranium & 1.7 & 1.5 & 0.4 & 1.8 & 2.7 & 1.4 & 1.6 \\
\hline Vanadium & 0.8 & 0.7 & 1.1 & 1.5 & 1.5 & 1.1 & 1.1 \\
\hline
\end{tabular}


location. However, water, sediment, and vegetation samples have not been collected from a comparable background location.

Based on one sampling round, the water quality in this pond does not exceed any of the available aquatic life water quality criteria (Table 7.4) or any of the available screening benchmarks for terrestrial plants or wildlife.

National Oceanic and Atmospheric Administration (NOAA) effects-based sediment quality values are available for evaluating the potential for constituents in sediment to cause adverse biological effects. These values are not standards or criteria. Effects range-low (ER-L) values are concentrations equivalent to the lower 10th percentile of available data screened by NOAA and indicate the low end of the concentration range in specific sediments at which adverse biological effects were observed or predicted in sensitive species and/or life stages. The effects-range median (ER-M) values are concentrations based on the NOAA screened data at which effects were observed or predicted in 50 percent of the test organisms evaluated. The NOAA ER-L and ER-M values were compared with the concentrations of the contaminants of potential concern detected in sediment of the pond at location 538 (Table 7.4). One of the limitations of the ER-L and ER-M is that the concentration at which toxicity was observed cannot be readily extrapolated from one sediment location to another; sediment characteristics (e.g., organic carbon content, grain/particle size) greatly influence contaminant toxicity. Therefore, the ER-L and ER-M cannot be used as direct indicators of adverse effects to benthic organisms, but can be provided as a benchmark for evaluating the potential for adverse effects.

The analysis of sediment samples showed that concentrations of arsenic and manganese exceed the sediment screening benchmark levels (Table 7.4). Although concentrations of uranium and vanadium were also high, no potential impact to environmental receptors can be determined because sediment benchmarks for these constituents are not available.

\section{Arsenic}

The arsenic concentration in the sediments was $13 \mathrm{mg} / \mathrm{kg}$ (Table 7.4), which exceeds the ER-L of $8.5 \mathrm{mg} / \mathrm{kg}$ where adverse effects may first be expected but is well below the effects range where adverse effects are expected in most cases (ER-M of $70 \mathrm{mg} / \mathrm{kg}$ ) (Long et al., 1993, as cited in Hull and Suter [1994]). This indicates that the arsenic in the sediments of pond 538 may be affecting sensitive benthic organisms but that widespread effects as a result of arsenic are unlikely.

\section{Manganese}

The manganese concentration of $610 \mathrm{mg} / \mathrm{kg}$ in the sediments at location 538 (Figure 7.2 and Table 7.4) exceeds the ER-L (460 mg/kg) but is less then the severe effects level $(1110 \mathrm{mg} / \mathrm{kg})$ established by the Province of Ontario (Persaud et al., 1990). This may indicate that manganese-contaminated 
Table 7.4 Water, sediment, and vegetation analysis at pond 538 near the Naturita, Colorado, site

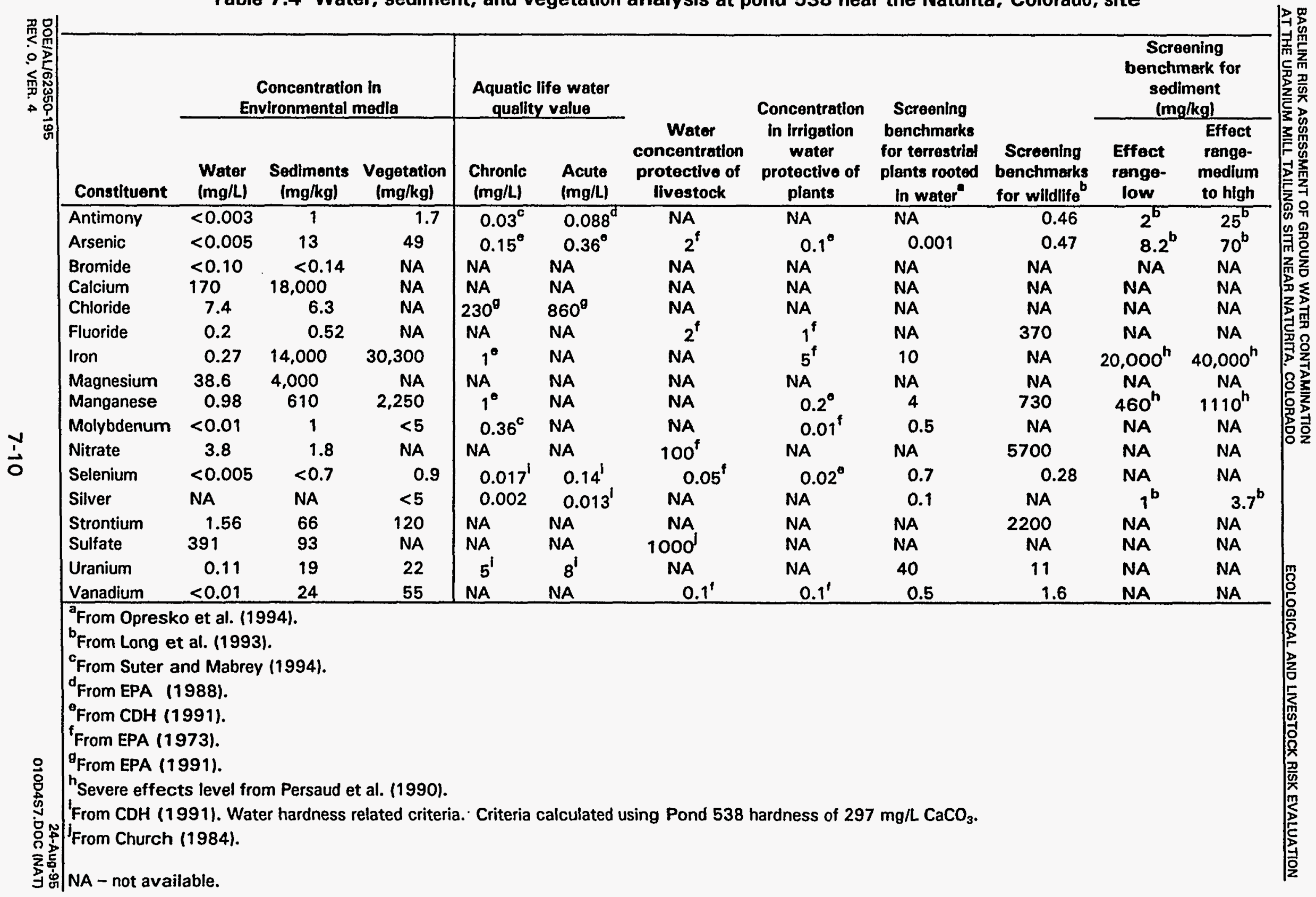




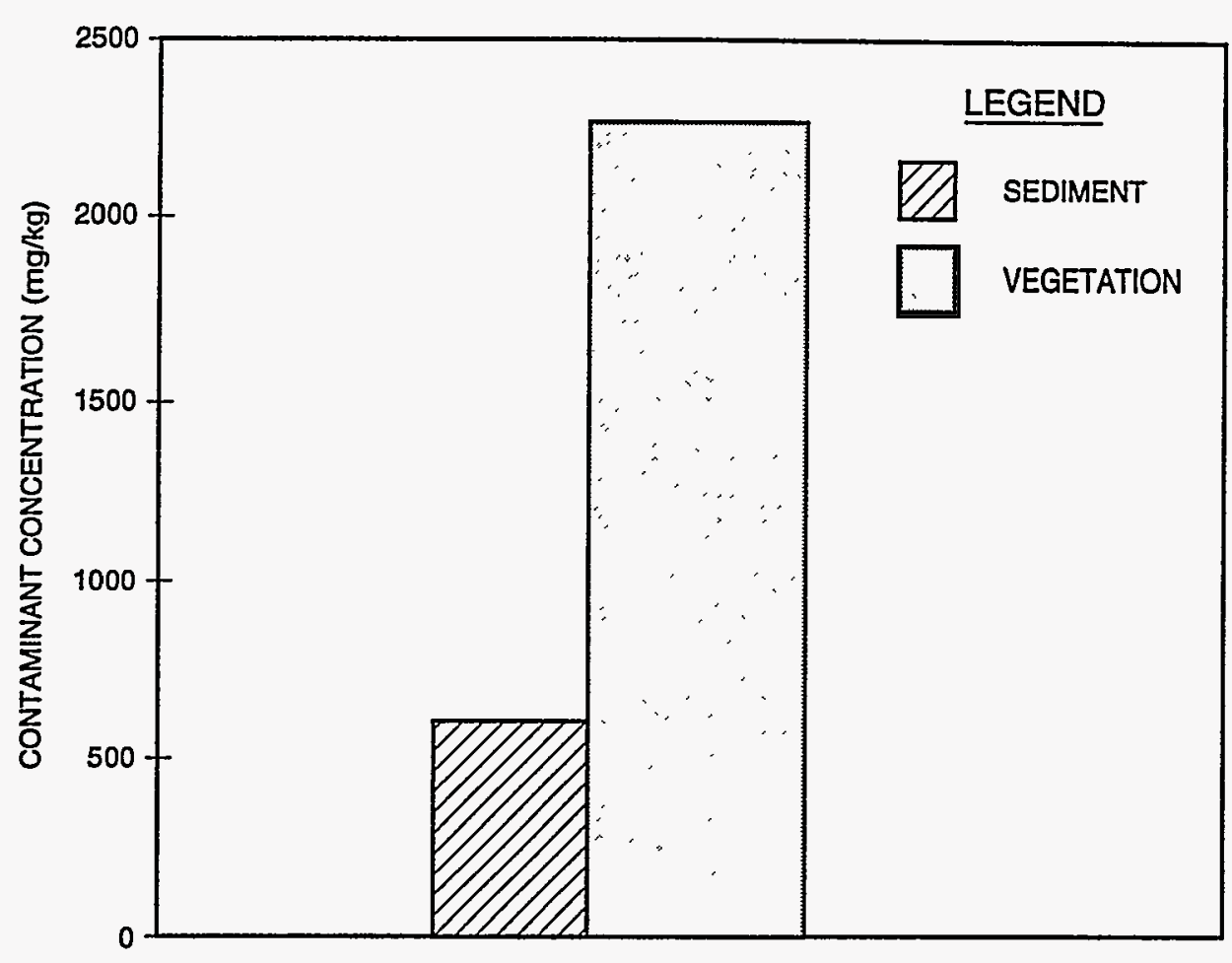

(a) managanese

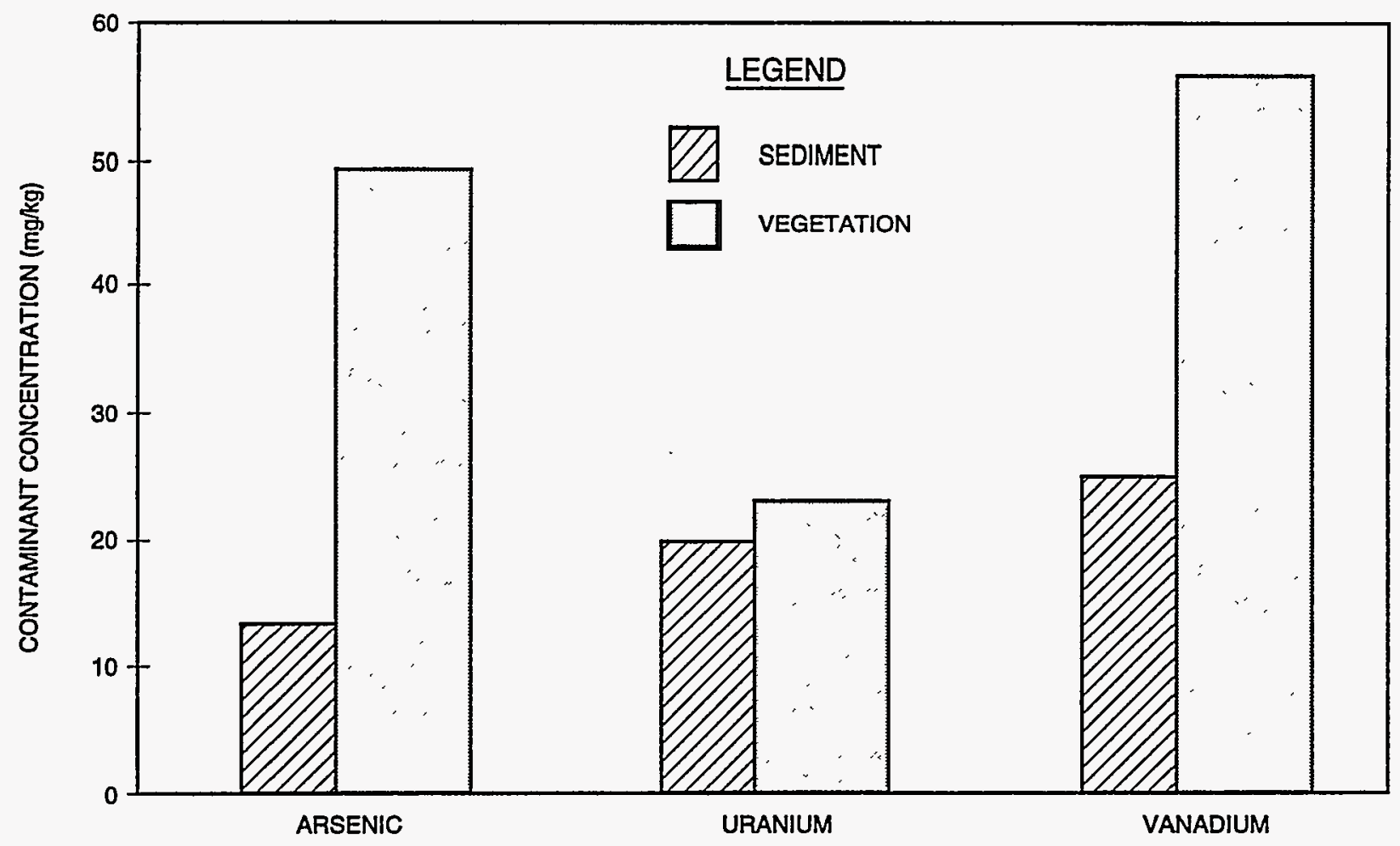

(b) arsenic, uranium, and vanadium

FIGURE 7.2

CONCENTRATIONS OF MANGANESE (a) AND ARSENIC, URANIUM, AND VANADIUM (b) IN SEDIMENT AND VEGETATION IN POND AT LOCATION 538

NATURITA, COLORADO, SITE 
sediment has a potential to result in toxic effects to benthic organisms; however, the range of these effects would be low.

Manganese is mostly insoluble in upland soils, but when those soils are flooded, microbial action renders manganese more soluble and available to plants (Gambrell, 1994). As shown in Table 7.4, the concentration of manganese in the plants at location $538(2250 \mathrm{mg} / \mathrm{kg})$ and the calculated sediment to plant bioconcentration factor for manganese is 3.7. This high bioconcentration factor of manganese in the plants may have resulted from anaerobic conditions at this location.

Plant tolerance to manganese varies with plant genotype and with nutritional and climatic factors. Therefore, the "specification of a critical toxicity concentration for manganese is hardly possible" (Horst, 1988). However, Horst (1982, as cited in Horst [1988]) did show that the leaves of some plant species were damaged and leaf shedding occurred at plant concentrations between 119 and $326 \mathrm{mg} / \mathrm{kg}$ while Horst (1988) determined that concentrations of 350 to $400 \mathrm{mg} / \mathrm{kg}$ manganese in plant tissue can cause leaf damage, particularly in older leaves. Concentrations of manganese at pond $538(2250 \mathrm{mg} / \mathrm{kg})$ may be phytotoxic. The effects of manganese on aquatic and terrestrial animal species are not known, although it is anticipated that the levels of this constituent in sediments and plants may have a deleterious affect on aquatic organisms living in the pond and terrestrial animals living near the pond.

\subsubsection{Alluvial ground water}

The contaminants of potential concern in the ground water from the alluvial aquifer are listed in the first column of Table 3.3. These contaminants can reach the environment by discharge to surface water bodies or by plant-root uptake of water directly out of the aquifer. The discharge of ground water from the alluvial aquifer to the pond at location 538 was addressed in Sections 3.2 and 7.3.2. An additional point of exposure, one that currently does not exist, would be the construction of a pond filled with the most contaminated ground water. The potential ecological impacts of constructing such a pond is discussed below.

\section{Potential ecological risk associated with plant root uptake of contaminants}

As indicated in Section 7.2 and shown in Figure 7.1, much of the Naturita site is within the floodplain of the San Miguel River. This floodplain sits on top of the alluvial aquifer, where the ground water level is 3 to $18 \mathrm{ft}(1$ to $6 \mathrm{~m})$ below land surface. Most of the plant species growing in the floodplain, such as willow and cottonwood, are rooted in this alluvial aquifer and depend on it for survival.

The upper ninety-fifth percent confidence level for the mean concentration of the contaminants of potential concern were compared to the screening benchmarks for terrestrial plants determined for water. Benchmarks are 
available for 9 of the 24 constituents. Of these, arsenic, manganese, and vanadium exceeded the benchmarks (Table 7.5).

\section{Arsenic}

Arsenic concentrations in the alluvial ground water were 54 times greater then the benchmark. Arsenic is actively taken up by plant roots. Symptoms of phytotoxicity noted in the literature include wilting of leaves, retardation of root and shoot growth, and leaf necrosis (Aller et al., 1990, as cited in Will and Suter [1994]). Phytotoxicity varies with the form of arsenic, with the inorganic forms being more toxic then the organic forms (Will and Suter, 1994). According to geochemical modeling, arsenic in the alluvial ground water is likely arsenate, as discussed in Section 3.5 (Table 3.4). Sanders and Osman (1985) determined that cordgrass growth was 25 percent less in the arsenic-dosed study plot than in control plots. The average arsenic concentration of the water in the Sanders and Osman (1985) study was $0.037 \mathrm{mg} / \mathrm{L}$, which is comparable to the contaminated ground water from the alluvial aquifer $(0.054 \mathrm{mg} / \mathrm{L})$. This indicates that the arsenic concentrations in the contaminated alluvial aquifer may be having a detrimental effect on plants. However, sampling of the vegetation and associated soil in the floodplain over the contaminated aquifer has not taken place, so the impact of arsenic contamination, if any, on the Naturita site-specific vegetation is not known.

\section{Manganese}

The manganese concentration in the contaminated alluvial aquifer $(6.4 \mathrm{mg} / \mathrm{L})$ is just above the screening benchmark for terrestrial vegetation $(4.0 \mathrm{mg} / \mathrm{L})$

(Table 7.5). Manganese is readily taken up by plant roots and transported to the shoots. Symptoms of toxicity include development of brown spots on the leaves, growth inhibition of young leaves, and chlorosis of young leaves (Horst, 1988). As indicated in Section 7.3.2, the effects of manganese on plants is variable, rendering the determination of a critical toxicity concentration difficult. Because the level of manganese in the contaminated ground water is close to the screening benchmark, the effect of this contaminant on vegetation, if any, is probably slight. However, sampling of the vegetation growing in the contaminated ground water has not taken place, so this assumption has not been verified.

\section{Vanadium}

The concentration of vanadium in the contaminated alluvial aquifer $(13 \mathrm{mg} / \mathrm{L})$ is 26 times greater then the screening benchmark for terrestrial plants $(0.5 \mathrm{mg} / \mathrm{L})$ (Table 7.5). After plant uptake, most vanadium remains in the root system where excessive amounts can inhibit root growth (Wallace and Romney, 1977; Pratt, 1966, as cited in Will and Suter, 1994). Various studies (Will and Suter, 1994) have shown that concentrations of vanadium ranging from 0.51 to 10 $\mathrm{mg} / \mathrm{L}$ have resulted in a reduction of plant root and shoot weight and length. Concentrations of vanadium in the contaminated alluvial aquifer may be 
Table 7.5 Contaminants of potential concern in the alluvial aquifer, Naturita, Colorado, site

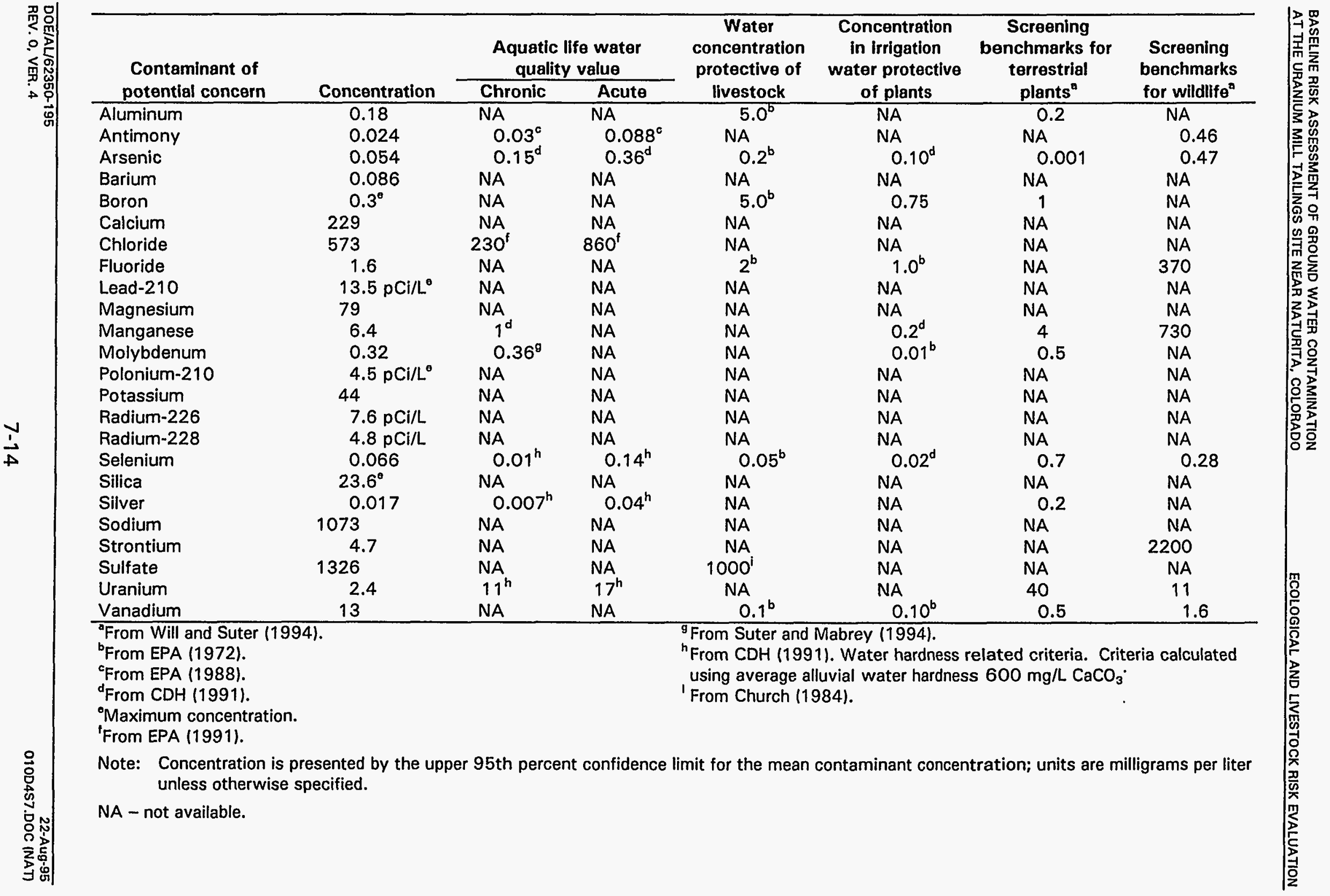


inhibiting the growth of plants in the floodplain at the Naturita site. However, as for other contaminants in the ground water, this potential for these effects has not been verified by site-specific field studies.

\section{Potential ecological risk of constructing a pond filled with water from the contaminated alluvial aquifer}

Construction of a pond filled with ground water from the alluvial aquifer (hypothetical pond) could result in a contaminated surface water body, thus creating a potential exposure point to ecological receptors and livestock. Such a hypothetical pond does not presently exist and there are no known plans to build such a pond. However, the potential does exist for such a hypothetical pond to be constructed in the future. The concentrations of the 24 contaminants of potential concern (see Table 7.5 ) observed in the contaminated ground water were compared with state and federal aquatic life water quality criteria and wildlife screening benchmarks. Eight constituents had aquatic life criteria. Of these, chloride, manganese, selenium, and silver exceeded the criteria (Table 7.5).

\section{Chloride}

Chloride concentrations ( $573 \mathrm{mg} / \mathrm{L}$ ) exceeded the federal chronic water quality criterion of $230 \mathrm{mg} / \mathrm{L}$. Data regarding the nature and severity of the effects of elevated chloride in aquatic and terrestrial ecological systems are not available.

\section{Manganese}

Manganese concentrations in the alluvial aquifer $(6.4 \mathrm{mg} / \mathrm{L})$ exceed the aquatic criterion for chronic effects of $1.0 \mathrm{mg} / \mathrm{L}$ (Table 7.5). Manganese could enter the hypothetical pond and likely accumulate in the sediments and aquatic plants that grow in the water, as was observed at location 538. As indicated above, manganese could be toxic to plants and aquatic life. The screening benchmark for terrestrial wildife is $730 \mathrm{mg} / \mathrm{L}$, which indicates that the hypothetical pond water would probably not have a detrimental effect on terrestrial wildlife that use the water for drinking.

\section{Selenium}

Selenium concentration $(0.066 \mathrm{mg} / \mathrm{L})$ exceeds the Colorado chronic criterion of $0.017 \mathrm{mg} / \mathrm{L}$ and is below the acute toxicity value of $0.14 \mathrm{mg} / \mathrm{L}$. The state criterion would likely be protective of aquatic life, but recent studies indicate that this criterion may not be protective of all components of the ecosystem. The safe selenium concentration in water recommended by the U.S. Fish and Wildlife Service is $0.002 \mathrm{mg} / \mathrm{L}$ (Lemly and Smith, 1987). Therefore, the worstcase concentrations in the contaminated alluvial aquifer exceed this safe level by 33 times. 
If a hypothetical pond were filled with the most contaminated ground water, selenium could impact aquatic vegetation and associated aquatic and terrestrial fauna. In addition, rooted aquatic plants that have bioconcentrated selenium could provide an additional source of selenium in this pond. As the plants die, this selenium would reenter the biological community through a variety of processes. Selenium that enters a relatively closed system could cycle through this environment for years, even if the selenium concentration in the ground water declines. The hypothetical pond would be a relatively closed system in that there would be little inflow and outflow of water; such a system could take several decades to recover from selenium contamination (Lemly and Smith, 1987). However, actual contaminant concentrations in such a hypothetical pond may differ from the levels in the most contaminated ground water, due to such factors as variability of ground water concentrations, rainfall, and evaporation.

\section{Silver}

Concentration of silver in the contaminated alluvial aquifer $(0.017 \mathrm{mg} / \mathrm{L})$ is approximately twice the Colorado chronic aquatic life criterion (Table 7.5). This indicates that use of this water for a hypothetical pond could result in chronic effects to aquatic invertebrates and fish. Harmful effects to aquatic plants are also possible. For example, the 96-hour median effective concentration (EC50) reported for some algae is as low as $0.0026 \mathrm{mg} / \mathrm{L}$. However, silver concentrations in the alluvial aquifer may not affect vascular aquatic plants, which have EC50s ranging from 0.27 to $7.5 \mathrm{mg} / \mathrm{L}$ (EPA, 1987b). The levels of silver in the contaminated alluvial aquifer are not expected to result in phytotoxicity based on a terrestrial plant benchmark of $0.2 \mathrm{mg} / \mathrm{L}$ (Table 7.5). Because there is no terrestrial wildlife benchmark for silver, the effect of silver on terrestial wildlife cannot be evaluated.

\section{Vanadium}

There is no state or federal aquatic life criterion for vanadium, but this constituent is of potential concern because it exceeds all the benchmarks presented in Table 7.5. Studies of aquatic organisms indicate that lethal concentrations of vanadium of 6.4 to $30.8 \mathrm{mg} / \mathrm{L}$ could result in the death of 50 percent of freshwater fish and freshwater aquatic worm (Smith et al., 1991). Aquatic life chronic criteria have not been established for vanadium, but EC20 benchmarks (comparable to chronic values) for fish and daphnids are 0.041 $\mathrm{mg} / \mathrm{L}$ and $0.43 \mathrm{mg} / \mathrm{L}$, respectively (Suter and Mabrey, 1994). Thus, the level of vanadium in the contaminated alluvial aquifer falls within the range of acute toxicity and is well above the concentrations that could result in chronic effects to aquatic life. Therefore, the vanadium concentrations in the hypothetical pond could be toxic to aquatic organisms.

Vanadium concentrations are 26 times greater then the screening level benchmark for terrestrial plants (Table 7.5) and exposure to this concentration may result in phytotoxicity. The concentrations of vanadium in the hypothetical 
pond may also be toxic to terrestrial wildlife because the concentration exceeds the terrestrial wildlife benchmark (Table 7.5).

\subsection{POTENTIAL AGRICULTURAL AND LIVESTOCK IMPACTS}

The potential effects of using contaminated water from location 538 and ground water for irrigation and stock watering are considered in this section. The concentrations of contaminants of potential concern were compared to values provided in the state of Colorado water quality standards (CDH, 1991) and EPA water quality criteria (EPA, 1973).

\section{Irrigation water}

Comparison of the contaminants of potential concern at location 538 with the irrigation benchmarks indicates that manganese concentrations are above the level considered safe for use in irrigation water (Table 7.4). However, it is unlikely that water from location 538 (the spring) would be used for irrigation, because considerably more effort is needed to capture the water from the spring than from other nearby sources.

The concentrations of manganese, molybdenum, selenium, and vanadium in the contaminated alluvial aquifer exceed the irrigation benchmarks (Table 7.5). Manganese levels of a few tenths to a few milligrams per liter can be toxic to some crops although this toxicity can be reduced by increasing the $\mathrm{pH}$ of the soil. Molybdenum concentrations in the contaminated alluvial aquifer $(0.32 \mathrm{mg} / \mathrm{L})$ would not be toxic to irrigated plants. However, molybdenum could bioconcentrate in plant tissue and become potentially toxic to livestock that fed on the forage irrigated with water from this aquifer (EPA, 1973). Selenium phytotoxicity varies greatly among agricultural plants (Lauchli, 1993). It has been found that concentrations as low as $0.025 \mathrm{mg} / \mathrm{L}$ in nutrient solution decreased the yields of alfalfa (Broyer et al., 1966, as cited in EPA [1973]). Studies have shown that concentrations of vanadium ranging from 0.5 to 10 $\mathrm{mg} / \mathrm{L}$ were toxic to a number of crops (EPA, 1973).

Sodium, calcium, and magnesium were used to calculate a sodium adsorption ratio (SAR) of 12 for the contaminated alluvial aquifer. Water having a SAR greater then 10 is not recommended for irrigation because it could lead to a breakdown in the soil causing it to become hard and compact when dry and increasingly impervious to water penetration (Follett and Soltanpour, 1985). Therefore, the use of the contaminated alluvial aquifer for irrigation could result in toxicity to plants because of elevated concentrations of metals and a breakdown in the soil structure as a result of high sodium concentrations.

\section{Stock watering}

Water concentrations protective of livestock have been established for some constituents (EPA, 1973) found in the water at location 538 and ground water in the alluvial aquifer at the Naturita site. Comparison of these levels with water 
quality data from surface water location 538 indicates that none of the levels considered protective of livestock were exceeded (Table 7.4).

Comparison of contaminant concentrations protective of livestock with the contaminant concentration from the worst quality ground water of the alluvial aquifer indicates that selenium and vanadium exceed established guideline values. In addition, sulfate concentrations $(1326 \mathrm{mg} / \mathrm{L})$ exceeded $1000 \mathrm{mg} / \mathrm{L}$; water with sulfate above $1000 \mathrm{mg} / \mathrm{L}$ may cause livestock to develop diarrhea (Church, 1984). The concentration of selenium in the alluvial aquifer is only slightly above the level protective of livestock, but would not result in chronic selenosis (Eisler, 1985). The concentration of vanadium in the alluvial aquifer exceeds the criterion protective of livestock by 130 times, indicating that this water could be toxic to livestock. Based on this information, use of the contaminated alluvial aquifer for livestock watering is not advisable.

\subsection{LIMITATIONS OF THE ECOLOGICAL RISK ASSESSMENT}

The qualitative evaluation of potential ecological risks presented here is a screening-level assessment. Sources of uncertainty in any ecological assessment arise from the monitoring data, exposure assessments, toxicological information, and inherent complexities of the ecosystem. In addition, methods of predicting nonchemical stresses (e.g., drought), biotic interactions, behavior patterns, biological variability (e.g., differences in physical conditions, nutrient availability), and resiliency and recovery capacities are often unavailable. In general, limitations for the Naturita ecological risk assessment include the following:

- Only a small amount of ecological data was collected during this screening.

- Little is known about site-specific intake rates for wildlife or amounts of contaminants taken up by plants.

- Only limited ecotoxicological reference data are available.

- Considerable uncertainty is associated with the toxicity of mixtures.

\subsection{SUMMARY}

The potential ecological risks associated with the site-related contamination of the alluvial aquifer at the Naturita site were assessed. The analysis focused on surface water bodies near the Naturita site and the contaminated alluvial aquifer beneath the Naturita site. This assessment also considered potential risks associated with using contaminated ground water for irrigation and livestock watering.

Water quality data show that contaminants of potential concern have not been detected above background levels in the San Miguel River, indicating that the 
activities of the Naturita site are not affecting the water quality of San Miguel River. Ground water discharge modeling confirms the validity of these observations. One round of river sediment and vegetation samples have been analyzed for a selected group of constituents. These limited data show that, for the constituents tested, there does not appear to be any difference in concentrations at the upstream and downstream locations.

Selected constituents from the spring-fed pond (location 538) were analyzed once. None of the constituents exceeded state or federal water quality aquatic life criteria. No data were collected at a background location. However, the concentrations of arsenic and manganese in sediment at location 538 are just above the low range of the sediment benchmarks, indicating they may be affecting the most sensitive species but probably not causing widespread toxicity.

Many plant species growing in the floodplain root in the aquifer. The comparison of screening benchmarks for terrestrial plants indicates that arsenic and vanadium concentrations in contaminated ground water are well above these benchmarks and may be toxic to plants growing in the floodplain of the Naturita site. However, no terrestial plants have been sampled from the Naturita site. Therefore, the effects to the plants growing in the floodplain cannot be determined.

The analysis of potential aquatic and terrestrial effects of building a pond that would be fed with water from the worst part of the contaminated aquifer indicates that chloride, manganese, selenium, and silver exceeded state or federal aquatic life criteria and have the potential to result in toxic effects to aquatic life. In addition, it is possible that contaminants such as selenium and silver could bioaccumulate and contaminate terrestrial biological communities. Vanadium concentrations are within the range of values known to result in acute toxicity and are well above the range of values known to cause chronic effects in aquatic life. Vanadium concentrations are also above the screening benchmark for wildlife, indicating that this contaminant could be toxic to terrestrial wildlife as well as aquatic life.

Based on limited sampling, location 538 water may not be safe for use in irrigation water because manganese exceeds the level considered protective of irrigation water. However, using the spring water for irrigation would be impractical. Water from the contaminated alluvial aquifer would not be appropriate for irrigating because manganese, molybdenum, selenium, and vanadium are above levels considered safe. In addition, the sodium adsorption ratio is above 10, indicating that use of this water may cause a breakdown in the soil structure.

Based on limited sampling, location 538 water would be safe for livestock to drink. Concentrations of selenium, sulfate, and vanadium in the contaminated alluvial aquifer is in excess of levels considered safe for livestock watering and could result in diarrhea and selenium poisoning. 


\subsection{INTERPRETATION AND RECOMMENDATION}

\subsection{RISK SUMMARY}

The UMTRA Project is required by the UMTRCA to protect public health and the environment from radiological and nonradiological hazards associated with 24 designated uranium mill sites. This baseline risk assessment was conducted on the contaminated ground water at the Naturita site to evaluate the presence of these hazards. This risk assessment is conservative in the sense that it evaluates a residential scenario which is associated with the highest level of exposure from drinking the water from the most contaminated wells on the Naturita site. Because contaminated ground water is not being used by area residents, human health is not currently at risk. This situation should continue if land use and water use at and downgradient of the Naturita site remain the same. Changes of land use may or may not create future risks. When specific land uses are determined for the Naturita site, these uses should be evaluated to identify potential health and environmental risks from the contaminated ground water.

Health risks could be associated with possible future use of contaminated ground water from the alluvial aquifer as drinking water; however, the likelihood of such use is considered low. The risks associated with possible future use of ground water for drinking might be unacceptable for sulfate, vanadium, manganese, sodium, and molybdenum. Persistent diarrhea could result in infants (the most sensitive population group) from short-term exposures to sulfate levels in ground water. The effect is reversible and diarrhea would terminate after the substitution of water low in sulfate for contaminated water. Vanadium exposure could intensify sulfate-induced diarrhea and other symptoms of gastrointestinal distress (such as intestinal cramps). Therefore, sulfate and vanadium acute toxicities could preclude chronic exposures. However, because different ground water contaminants flush out at different rates and because remedial action strategies may differ for different contaminants, the health effects from long-term exposures to contaminants other than sulfate and vanadium are also discussed. This water is potentially in the mild toxicity range following long-term ingestion exposures to manganese, sodium, and molybdenum. Manganese levels could produce neurological symptoms including memory loss, irritability, and muscle rigidity. Sodium levels could cause hypertension in sensitive individuals. Copper deficiency anemia and increased production of uric acid in the human body could be associated with molybdenum exposure levels. If this ground water were used for drinking water, possible lifetime exposures to radioactive uranium, its progeny and radium-228 could be associated with an overall excess lifetime cancer risk of about 4 in 1,000; this exceeds the maximum excess cancer risk of 1 in 10,000 recommended as acceptable by the EPA for Superfund sites (40 CFR Part 300 (1994)). In addition, lifetime excess risk of skin cancer associated with arsenic levels (about 2 in 1,000) could also exceed the maximum excess cancer risk of 1 in 10,000 recommended by the EPA (40 CFR Part 300 (1994)). Note, however, that in 
the future resident scenario, only the people who would drill a well in the most contaminated portion of the aquifer (a fraction of the Naturita site) could experience health problems discussed above. Drinking the water from a future well drilled further off site would be associated with risks lower than estimated here. Furthermore, the ground water contaminant concentrations are expected to decline over time after removal of contaminated soils from the Naturita site.

The potential human exposure contribution from other pathways, including ingestion of ground water-irrigated produce, consumption of meat or milk from cattle grazed on ground water-irrigated pasture and watered with contaminated ground water, could not be estimated with current data. Although drinking water ingestion is assumed to result in the greatest exposure, other pathways may contribute to overall exposure and are of interest because plant uptake could occur under current site condition and food chain transfer has a potential to occur in the future.

Although the potential for current exposure to a surface expression of ground water (the spring) exists in the area of the floodplain downgradient of and adjacent to the Naturita site, based on current data, these exposures are not expected to adversely affect human health. Additionally, adverse health effects would not be expected following ingestion of meat and milk from future cattle grazed and watered on the San Miguel River floodplain. However, this evaluation is based on very limited data. Additional data are required to completely evaluate the meaningfulness of these exposure pathways.

Use of the contaminated ground water to create a pond is not recommended because levels of chloride, manganese, selenium, silver, and vanadium may result in toxicity to aquatic and terrestrial life, while levels of selenium, sulfate, and vanadium could be harmful to livestock. In addition, this contaminated ground water is not recommended for irrigation due to high levels of manganese, molybdenum, selenium, radium and vanadium.

The spring water is safe for aquatic and terrestrial organisms as well as for livestock watering. The spring sediment, however, may be toxic to aquatic organisms and terrestrial plants. It is difficult to determine from limited sediment data whether the San Miguel River sediments at the Naturita site are contaminated from site-related activities.

\subsection{LIMITATIONS OF THIS RISK ASSESSMENT}

The following limitations to this evaluation of health and environmental risks should be noted:

- Because future land development is unknown, actual exposure pathways could not be determined.

- Uncertainties arise from the use of filtered versus unfiltered water samples. In general, the results presented in this document are based on filtered 
$(0.45-\mu \mathrm{m})$ water samples. The effect of filtration differs for different elements. Filtered samples for some constituents can have concentrations equal to or lower than unfiltered samples. Constituents in suspension may be lost with filtration, but can still produce toxic effects if ingested and broken down in the acidic environment of the stomach.

- This risk assessment does not address all individual sensitivities to toxicity of contaminants of potential concern. Contaminant toxicities vary from person to person. Presenting probability distributions for potential exposure and exposure ranges that can produce toxic effect emphasizes these variabilities. However, it is not possible to account for all sources of variability. Specific subpopulations known to be more sensitive to the toxicity of given constituents are noted. Adverse health effects might occur at lower exposure levels in sensitive individuals.

- Standardized reference values from regulatory agencies and literature values are used to determine toxic effects in humans. However, some data obtained from laboratory animal testing at exposure doses different from those expected at the Naturita site were used to determine toxicity. The relationship between dose and response is not always linear, and humans do not always exhibit the same responses as animals. Additionally, data used to determine toxicity generally are based on exposure to only the constituent of concern. In reality, exposures generally occur simultaneously to multiple constituents. The interactive effects of multiple constituents and the impact of these interactions on expected toxicity generally cannot be accurately assessed from existing data.

- Although considerable effort was directed at determining the areal extent of contaminated ground water, its movement and placing monitor wells in locations that capture maximum contamination, variability in physical systems and models used to determine contaminant plume migration could still result in well placements that do not measure the highest contaminant concentrations or determine the fullest extent of plume impact.

- Some variability may have been introduced through sampling and analytical processes. However, the data at UMTRA Project sites have been collected over many years and subjected to rigorous quality assurance procedures to minimize this source of uncertainty. Testing multiple samples introduces high confidence in the reliability and validity of the collected data.

- The incremental contribution from the ground water-irrigated produceingestion or meat-ingestion pathways to the total exposure could not be estimated here. Therefore, the exposure from these pathways should be considered.

- A limited amount of ecological data was collected for this screening. In addition, little is known about site-specific intake rates for wildlife and 
amounts of contaminants taken up by plants. Limited ecotoxicological reference data and considerable uncertainty associated with the toxicity of mixed contaminants add to the limitations of this risk assessment.

By presenting ranges of toxic effects, probable exposure distributions, summaries of available data on health effects and interactions, and outlines of potential limitations, this risk assessment ensures a reasonable interpretation of potential health risks associated with ground water site-related contamination at the Naturita site.

\subsection{GROUND WATER CRITERIA}

In 1983, the EPA established health and environmental protection standards for the UMTRA Project (40 CFR Part 192). The standards were revised and the final rule was published 11 January 1995 (60 FR 2854 (1995)). The ground water standards consist of ground water protection standards to evaluate disposal cell performance and ground water cleanup standards for existing contamination at processing sites. Concentration limits for constituents at the Naturita site are summarized in Table 8.1. Maximum concentration limits (MCLs) are not established for every contaminant; for contaminants without MCLs, background levels must be met, although the standards also allow for supplemental standards or alternate concentration limits $(A C L)$ where appropriate.

In general, the EPA ground water standards are sufficient to protect human health and the environment. However, there may be site-specific factors that suggests these standards are not appropriate. For example, standards may be too restrictive if there is no potential for exposure and a less restrictive ACL may be sought. In other cases, the standards may not be sufficiently protective (e.g., if many contaminants near the MCL have additive or synergistic adverse health effects).

While these ground water standards apply specifically to the UMTRA Project, the EPA has also published drinking water health advisory levels (EPA, 1995) for both long-term and short-term exposures. These advisories are also shown in Table 8.1.

The following site-related contaminants have consistently exceeded the EPA ground water standards and/or the EPA health advisory levels in contaminated alluvial monitor wells: antimony, arsenic, molybdenum, selenium, vanadium, radium-226/-228, and uranium. Cadmium exceeded its $M C L$ (in alluvial monitor well 630) and health advisory (in alluvial monitor wells 630 and 656) once. Nitrate slightly exceeded its $\mathrm{MCL}$ and health advisory ( $45 \mathrm{mg} / \mathrm{L}$ versus $44 \mathrm{mg} / \mathrm{L}$ ). Radium-226/-228 slightly exceeded its MCL in background well 547 once. Uranium is the only contaminant which exceeded its $\mathrm{MCL}$ and health advisories in the spring water. 
Table 8.1 Concentration limits of constituents for the ground water, Naturita, Colorado, site

\begin{tabular}{|c|c|c|c|}
\hline \multirow[b]{2}{*}{ Constituent } & $\begin{array}{c}\text { EPA maximum } \\
\text { concentration of } \\
\text { constituents in ground } \\
\text { water for UMTRA } \\
\text { Project sites }\end{array}$ & $\begin{array}{c}\text { Health advisories, } \\
\text { 10-kg } \\
\text { child, 10-day }\end{array}$ & $\begin{array}{c}\text { Health advisories, } \\
70-\mathrm{kg} \\
\text { adult, lifetime } \\
\end{array}$ \\
\hline & \multicolumn{3}{|c|}{$(\mathrm{mg} / \mathrm{L})$} \\
\hline \multicolumn{4}{|l|}{ Chemical (inorganic) } \\
\hline Antimony & NA & $0.01^{b}$ & $0.003^{b}$ \\
\hline Arsenic & $0.05^{b}$ & NA & NA \\
\hline Barium & 1.0 & NA & 2 \\
\hline Boron & NA & 0.9 & 0.6 \\
\hline Cadmium & $0.01^{b}$ & 0.04 & $0.005^{b}$ \\
\hline Chromium & 0.05 & $1.0^{c}$ & $0.1^{c}$ \\
\hline Lead & 0.05 & NA & $0.015^{d}$ \\
\hline Mercury (inorganic) & 0.002 & NA & 0.002 \\
\hline Molybdenum & $0.1^{b}$ & $0.04^{b}$ & $0.04^{b}$ \\
\hline Nickel & NA & 1.0 & 0.1 \\
\hline Nitrate & $44^{b, e}$ & $44^{b, f}$ & NA \\
\hline Selenium & $0.01^{b}$ & NA & NA \\
\hline Silver & 0.05 & 0.2 & 0.1 \\
\hline Strontium & NA & 25.0 & 17 \\
\hline Thallium & NA & $0.007^{g}$ & $0.0004^{9}$ \\
\hline Zinc & NA & 6.0 & 2 \\
\hline \multicolumn{4}{|l|}{ Radionuclide } \\
\hline Radium-226/-228 & $5 \mathrm{pCi} / \mathrm{L}^{\mathrm{b}, \mathrm{h}}$ & NA & NA \\
\hline Uranium (U-234/ & $30 \mathrm{pCi} / L^{b, i}$ & $0.03 \mathrm{mg} / \mathrm{L}^{\mathrm{b}, \mathrm{i}, \mathrm{j}}$ & $0.1 \mathrm{mg} / \mathrm{L}^{\mathrm{b}, \mathrm{i}, \mathrm{k}}$ \\
\hline & (0.044 mg/L) & & \\
\hline 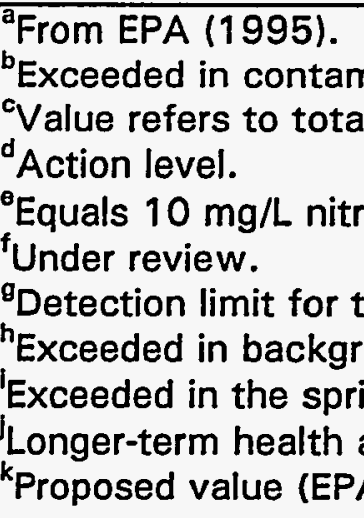 & $\begin{array}{l}\text { inated well samples. } \\
\text { chromium. } \\
\text { te as nitrogen. } \\
\text { allium was } 0.01 . \\
\text { und well samples. } \\
\text { g. } \\
\text { dvisory. } \\
\text { 1989e), under revie }\end{array}$ & sion experter & 5 \\
\hline
\end{tabular}




\subsection{RISK MITIGATION MEASURES}

Use of the contaminated ground water from the alluvial aquifer below the Naturita former uranium processing site could cause health problems. However, water from the affected aquifer is not known to be used for any purpose at the downgradient of the Naturita site. Note, however, that contaminated ground water expresses itself in the spring on the San Miguel River floodplain creating possible exposure pathways to environmental receptors.

Institutional controls are defined in the EPA ground water standards as mechanisms that can be effectively used to protect human health and the environment by controlling access to contaminated ground water. Although institutional controls may be used for long periods of time (e.g., up to 100 years during natural flushingl, they can also be applied to short-term restriction of access to contaminated ground water. Since not all 24 UMTRA Project sites can be evaluated simultaneously, short-term institutional controls may be needed before remedial action decisions are made and implemented for individual sites.

\section{Well permits}

All of the Colorado UMTRA Project sites are located on the Colorado West Slope and are outside the designated ground water basins. Construction of new wells in Colorado outside the designated basins requires a written application to the Colorado state engineer for a permit. Designated basins are isolated hydrogeologic areas where groundwater use is stringently evaluated based on the demands for water rights. The State Engineer is required to act on applications for new well permits within $\mathbf{4 5}$ days after their receipt. If a well would effect existing water rights or if an applicant wants to establish a legal right, adjudication would likely be required prior to the permit being granted.

\section{Ground water quality}

The Colorado Department of Public Health is the state agency responsible for setting water quality standards. Within the Colorado Department of Public Health the State Water Quality Control Commission is responsible for adopting the water quality standards and classifications for state waters in Colorado.

The state of Colorado proposed ground water quality standards require ground water to be free of substances in concentrations shown to be "carcinogenic, mutagenic, teratogenic or toxic to human beings and /or a danger to public health, safety, or welfare." (CDH, 1990).

The state engineer is authorized to enforce the state water quality standards. However, the Colorado state engineer does not have jurisdiction to deny a permit for drilling new wells based on water quality; private domestic well water quality is not regulated by the state. However, the state engineer's office can issue a warning to well users if the well is placed in a known contaminated 
aquifer. Well water to be consumed by 25 or more people does have to meet state water quality standards and use can be restricted by the Colorado Department of Health, Water Quality Control Division, Drinking Water Section.

\section{Land restrictions}

The former uranium processing site is located outside of the town of Naturita and not subject to city requirements; Montrose County has jurisdiction over the Naturita site. The land is currently zoned agricultural by the county zoning ordinance. For land uses other than agricultural, a special use permit has to be obtained from the county. If the land is used for grazing or other agricultural activities, no permit is required.

\subsection{RECOMMENDATIONS}

The shallow ground water under and downgradient of the Naturita site in the alluvial aquifer is currently not being used for domestic purposes. It is recommended that the use of this ground water for domestic, agricultural, and livestock purposes be restricted in the future until the water quality improves.

Several additional characterization activities are recommended for consideration in future site characterization workplans to help resolve uncertainties associated with potential risks to human health and the environment and to provide input to future decisions regarding site-related contamination in ground water.

- Sampling (under filtered and unfiltered conditions) of designated monitor wells should be considered to develop a statistically defensible data set for ground water decisions.

- Subsurface information concerning the alluvium/bedrock interface would be useful to determine the vertical extent of the alluvial aquifer and the relationship of the river channel to the alluvial aquifer and underlying bedrock.

- The installation of additional monitor wells at the Naturita site and at locations downgradient from the Naturita site, the collection of additional samples from upgradient (background), on-site wells, and at locations downgradient from the Naturita site, would provide useful information regarding the extent of contamination, contaminant transport characteristics, and the effectiveness of surface program source removal actions.

- Site-specific information on the seasonal aspects of surface water/ground water interaction would be useful to verify assumed recharge and discharge characteristics for the alluvial aquifer. 
- Additional ground water quality samples should be considered from the north side of the San Miguel River, downgradient from the Naturita site, to assess the potential for exposure and/or need for ground water use restrictions due to underflow.

- A background spring location should be identified and sampled to compare the water to location 538 sampling.

- Vegetation and soil samples should be collected from the floodplain above the contaminated alluvial aquifer and at a background location to determine the impact, if any, of the contaminated ground water on vegetation growing in the floodplain area. 


\subsection{LIST OF CONTRIBUTORS}

The following individuals contributed to the preparation of this report.

\begin{tabular}{ll}
\hline Name & Contribution \\
\hline R. Neri Zagal & Document coordinator; risk mitigation measures \\
B. Malczewska-Toth & Risk assessment; toxicology \\
C. Burt, M. Randall & Ecology \\
K. Smith & Statistics \\
J. Carmen & Hydrogeology \\
D. Erskine & Geochemistry \\
J. Storm, J. Gibb & Senior technical review \\
R. Saar, A. Holm & Technical review \\
E. Artiglia & Site manager \\
& Document review \\
& Graphic design \\
D. Tamez & Editing \\
L. Sanchez & Text processing \\
\hline
\end{tabular}




\subsection{REFERENCES}

Ackerman, D.J., and F. E. Rush, 1984. Hydrogeological Reconnaissance of the San Miguel River Basin, Southwestern Colorado, U.S. Geological Survey, Water Resources Investigation Report 84-4133, USGS, Lakewood, Colorado.

Aiyar, A. S., and A. Sreenivasan, 1961. "Effect of Vanadium Administration on Coenzyme Q Metabolism in Rate," in Proc. Sauce. Exp. Biol. Med., Vol. 107, pp. 914-916.

Alexander et al. (F. W. Alexander, B. E. Clayton, and H. T. Delves), 1974. "Mineral and Trace-metal Balances in Children Receiving Normal and Synthetic Diets," in O.J. Med., Vol. 43, pp. 89-111.

Aller et al. (A. J. Aller, J. L Bernal, M. J. del Nozal, and L. Deban), 1990. "Effect of Insecticide Fertilizer Mixtures and Seed Treatments on Emergence of Sugar Beet Seedlings," Journal of Science Food Agriculture, Volume 51. pp. 447-479.

Baes et al. (C. F. Baes III, R. D. Sharp, A. L. Sjoreen, and R. W. Shor), 1984. A Review and Analysis of Parameters for Assessing Transport of Environmentally Released Radionuclides Through Agriculture, ORNL-5786, prepared for Oak Ridge National Laboratory, Health and Safety Research Division, Oak Ridge, Tennessee.

Ballou et al. (J. E. Ballou, R. A. Gies, A. C. Case, D. L. Haggard, R. L. Buschbom, and J. L. Ryan), 1986. "Deposition and Early Disposition of Inhaled Uranium-233 Uranyl Nitrate and Uranium-232 Uranyl Nitrate in the Rat," Health Physics, No. 51, pp. 755-772.

Belehova, B. A., 1969. Scientific Transactions of the Irkutsk State Medical Institute, Vol. 96, pp. 20-23 (in Russian).

Berlin, M., and B. Rudell, 1986. "Uranium," in Handbook on the Toxicology of Metals, second edition, L. Friberg, G. F. Nordberg, and V. B. Vouk, eds., pp. 647-658, Elsevier Science Publishers, New York, New York.

Bopp et al. (B. A. Bopp, R. C. Sanders, and J. W. Kesterson), 1982. "Metabolic Fate of Selected Selenium Compounds in Laboratory Animals and Man," in Drug Metab. Rev., Vol. 13, pp. 271-318.

Brod, R. C. and Stone, W. J., 1981. Hydrogeology of Ambrosia Lake - San Mateo area, McKinley and Cibola Counties, New Mexico: Hydrologic Sheet 2 New Mexico Bureau of Mines and Mineral Resources, Socorro, NM.

Broyer et al. (T. C. Broyer, D. C. Lee, and C. J. Asher), 1966. "Selenium Nutrition of Green Plants; Effect of Selenite Supply on Growth and Selenium Content of Alfalfa and Subterranean Clover," Plant Physiology, Volume 9. pp. 1425-1428. 
Buchet et al. (J. P. Buchet, R. Lauwerys, and H. Roels), 1981. "Urinary Excretion of Inorganic Arsenic and its Metabolites After Repeated Ingestion of Sodium Metaarsenite by Volunteers", in International Archives of Occupational and Environmental Health, No. 48, pp. 111-118.

Buchet et al. (J. P. Buchet, H. Roels, and R. Lauwerys), 1980. "Repeated Surveillance of Exposure to Cadmium, Manganese, and Arsenic in School-Age Children Living in Rural, Urban, and Nonferrous Smelter Areas in Belgium," in Environmental Research, No. 22, pp. 95-108.

Byerrum et al. (R. U. Byerrum, R. E. Eckardt, L. L. Hopkins), 1974. Vanadium, National Academy of Sciences, Washington, D.C.

Byrne, A. R., and L. Kosta, 1978. Sci. Total Environ., Vol. 10, pp. 17-30.

Calabrese, E. J., and R. W. Tuthill, 1977. "Elevated Blood Pressure and High Sodium Levels in the Public Drinking Water," in Archives of Environmental Health, September/October 1977, pp. 200-202.

Carruthers, R. V., 1986. Umcompahgre Basin Resource Area, U.S. Bureau of Land Management, Montrose, Colorado, personal communication to Charles Burt, Jacobs Engineering Group, Inc., Albuquerque, New Mexico, dated March 27, 1986.

Carson et al. (B. L. Carson, H. V. Ellis III, and J. L. McCann), 1986. Toxicology and Biological Monitoring of Metals in Humans, Lewis Publishers, Inc., New York, New York, pp. 226-230.

Casarett, L. J., and J. Doull, 1991. Toxicology: The Basic Science of Poisons, fourth edition, M. O. Amdur, J. Doull, and C. D. Klaassen, eds., Pergamon Press, New York, New York.

CDH (Colorado Department of Health), 1991. Basic Standards and Methodologies for Surface Water, 3.1.0, Water Quality Control Commission, Denver, Colorado.

CDH (Colorado Department of Health), 1990. Ground Water Quality Standards, 3.11.5A, The Basic Standards for Ground Water, Water Quality Control Commission, Denver, Colorado.

CDOW (Colorado Division of Wildlife), 1977. "San Miguel River \#1 (Fisheries Survey of the San Miguel River)," Code No. 46842, CDOW, Montrose, Colorado.

Chenoweth, W. L., 1978. Uranium in Western Colorado, The Mountain Geologist, V14, No. 3, p. 89-96.

Chien et al. (L. Chien, H. Robertson, and J. W. Gerrard), 1968. "infantile Gastroenteritis," in Canadian Medical Association Journal, Vol. 99, July 20, pp. 102-104. 
Church, D. C., 1984. Livestock Feeds and Feeding, second edition, McGraw-Hill Publishing Co., New York, New York.

Cothern, C. R., and W. L. Lappenbusch, 1983. "Occurrence of Uranium in Drinking Water in the United States," in Health Physics, No. 45, pp. 89-99.

Crecelius, E. A., 1977. "Changes in the Chemical Speciation of Arsenic following Ingestion by Man," in Environmental Health Perspective, No. 19, pp. 147-150.

Cummins, L. M., and E. T. Kimura, 1971. Toxicological Applied Pharmacology, Vol. 20, pp. 89-96.

Curran et al., (G. L. Curran, D. L. Azarnoff, and R. E. Bolinger), 1959. "Effect of Cholesterol Synthesis Inhibition in Norme-cholesteramic Young Men," in J. Clin. Invest., Vol. 38, pp. 1251-1261.

DHHS (U.S. Department of Health and Human Services), 1992a. Toxicological Profile for Antimony and Compounds, U.S. Department of Health and Human Services, Public Health Service, Agency for Toxic Substances and Disease Registry.

DHHS (U.S. Department of Health and Human Services), 1992b. Toxicological Profile for Manganese, U.S. Department of Health and Human Services, Atlanta, Georgia.

DHHS (U.S. Department of Health and Human Services), 1992c. Toxicology Profile for Vanadium and Compounds, U.S. Department of Health and Human Services, Public Health Service, Agency for Toxic Substances and Disease Registry.

DHHS (U.S. Department of Health and Human Services), 1992d. Toxicology Profile for Aluminum and Compounds, U.S. Department of Health and Human Services, Public Health Service, Agency for Toxic Substances and Disease Registry.

DHHS (U.S. Department of Health and Human Services), 1993. "Toxicological Profile for Arsenic," prepared by Syracuse Research Corporation for the U.S. Department of Health and Human Services, Public Health Service, Agency for Toxic Substances and Disease Registry, Atlanta, Georgia.

DHHS (U.S. Department of Health and Human Services), 1989. Toxicological Profile for Selenium, prepared by Clement Associates for the Agency for Toxic Substances and Disease Registry, U.S. Public Health Service, in collaboration with the U.S. Environmental Protection Agency.

Dimond et al. (E. G. Dimond, J. Caravaca, and A. Benchimol), 1963. "Vanadium: Excretion, Toxicity, Lipid Effect in Man," in American Journal of Clinical Nutrition, Vol. 12, pp. 49-53. 
DOE (U.S. Department of Energy), 1994a. Human Health Risk Assessment Methodology for the UMTRA Ground Water Project, DOE/AL/62350-170, prepared by the U.S. Department of Energy, UMTRA Project Office, Albuquerque Operations Office, Albuquerque, New Mexico.

DOE (U.S. Department of Energy), 1994b. Remedial Action Plan for the Inactive Uranium Processing Site at Naturita Colorado, DOE/AL/62350-142, prepared by the U.S. Department of Energy, UMTRA Project Office, Albuquerque Operations Office, Albuquerque, New Mexico.

DOE (U.S. Department of Energy), 1994c. Environmental Assessment of Remedial Action at the Naturita Uranium Processing Site Near Naturita, Colorado, DOE/EA-0464, DOE UMTRA Project Office, Albuquerque Operations Office, Albuquerque, New Mexico.

DOE (U.S. Department of Energy), 1995a. Supplement to the Baseline Risk Assessment of Ground Water Contamination at the Uranium Mill Tailings Site Near Naturita, Colorado, DOE/AL/62350-XXXS, prepared by the U.S. Department of Energy, UMTRA Project Office, Albuquerque Operations Office, Albuquerque, New Mexico.

DOE (U.S. Department of Energy), 1995b. Baseline Risk Assessment of Ground Water Contamination at the Uranium Mill Tailings Sites Near Rifle, Colorado, DOE/AL/62350-179, prepared by the U.S. Department of Energy, UMTRA Project Office, Albuquerque Operations Office, Albuquerque, New Mexico.

Eisler, R., 1985. "Selenium Hazards to Fish, Wildlife, and Invertebrates: A Synoptic Review", U.S. Fish and Wildlife Service, Biological Report 85(1.5), Patuxent Wildlife Research Center, Laurel Maryland.

EPA (U.S. Environmental Protection Agency), 1995. Drinking Water Regulations and Health Advisories, Office of Water, Washington, D.C.

EPA (U.S. Environmental Protection Agency), 1994a. Integrated Risk Information System (IR/S), database, Office of Research and Development, Washington, D.C.

EPA (U.S. Environmental Protection Agency), 1994b. Health Effects Assessment Summary Tables (HEAST), Supplement No. 2, Office of Research and Development, Washington, D.C.

EPA (U.S. Environmental Protection Agency), 1992a. Dermal Exposure Assessment: Principles and Applications, EPA/600/8-91/011B, Office of Health and Environmental Assessment, U. S. Environmental Protection Agency, Washington, D.C.

EPA (U.S. Environmental Protection Agency), 1992b. Drinking Water Criteria Document for Sulfate, final, Health and Environmental Criteria Division, Office of Science and Technology, U.S. Environmental Protection Agency, Washington, D.C. 
EPA (U.S. Environmental Protection Agency), 1991. 304(a) Criteria and Related Information for Toxic Pollutants, EPA Region IV, Water Management Division.

EPA (U.S. Environmental Protection Agency), 1989a. Risk Assessment Guidance for Superfund, Vol. 1, Human Health Evaluation Manual, EPA/540/1-89/002, Office of Emergency and Remedial Response, Washington, D.C.

EPA (U.S. Environmental Protection Agency), 1989b. Risk Assessment Guidance for Superfund, Vol. II, Environmental Evaluation Manual, EPA/504/1-89/001, Office of Emergency and Remedial Response, Washington, D.C.

EPA (U.S. Environmental Protection Agency), 1989c. Drinking Water Criteria Document for Uranium, external review draft, Criteria and Standards Division, Office of Drinking Water, Washington, D.C.

EPA (U.S. Environmental Protection Agency), 1988. Draft Ambient Aquatic Water Quality Criteria for Antimony (III), EPA, Office of Research and development, Environmental Research Laboratories, Duluth, Minnesota.

EPA (U.S. Environmental Protection Agency), 1987a. Health Effects Assessment for Vanadium and Compounds, U.S. Environmental Protection Agency, Environmental Criteria and Assessment Office, Cincinnati, Ohio, July 1987.

EPA (U.S. Environmental Protection Agency), 1987b. “Draft Ambient Water Quality Criteria for Sliver, "EPA, Office of Research and Development, Environmental Research Laboratories, Duluth, Minnesota.

EPA (U.S. Environmental Protection Agency), 1984. Health Assessment Document: Inorganic Arsenic, U.S. Environmental Protection Agency, Washington, D.C.

EPA (U.S. Environmental Protection Agency), 1980. Ambient Water Quality Criteria for Selenium, EPA 440/5-80-070, NTIS PB 81-117814, prepared by the Office of Health and Environmental Assessment, Environmental Criteria and Assessment Office, Cincinnati, Ohio, for the Office of Water Quality Planning Standards, Washington, D.C.

EPA (U.S. Environmental Protection Agency), 1977. Scientific and Technical Assessment Report on Vanadium, EPA-600-6-77-002, U.S. Environmental Protection Agency, Washington, D.C.

EPA (U.S. Environmental Protection Agency), 1973. Water Quality Criteria, National Academy of Science and National Academy of Engineering, Washington, D.C.

Evans, A. M., 1987. An Introduction to Ore Geology, Blackwell Scientific Publications, Boston, Massachusetts, 358 p. 
FB\&DU (Ford, Bacon \& Davis Utah, Inc.), 1981. Engineering Assessment of Inactive Uranium Mill Tailings, Naturita Site, Naturita, Colorado, prepared for the U.S. Department of Energy, UMTRA Project Office, Albuquerque Operations Office, Albuquerque, New Mexico.

Fenneman, N. M., 1946. Physical Divisions of the United States: U.S. Geological Survey map, scale 1:7,000,000 (Reprinted, 1964)

Ferm, V. H., 1971. "The Teratogenic Profile of Sodium Arsenate in the Golden Hamster," in Archives of Environmental Health, No. 22, pp. 557-560.

Fisenne et al. (I. M. Fisenne, P. M. Perry, and N. H. Harley), 1988. "Uranium in Humans," in Radiation Protection Dosimetry, No. 24, pp. 127-131.

Follett, R. H. and P. N. Soltanpour, 1985. "Irrigation Water Quality Criteria," Colorado State University Extension Service, Colorado State University, Fort Collins, Colorado.

Freis, E. D., 1976. "Salt, Volume and the Prevention of Hypertension," in Circulation, Vol. 53, No. 4, pp. 589-595.

Friberg et al. (L. Friberg, G. F. Nordberg, and V. B. Vouk), 1986. Handbook on the Toxicology of Metals, Volume II: Specific Metals, second edition, Elsevier, New York, New York.

Gambrell, R. P., 1994. "Trace and Toxic Metals in Wetlands - a Review," Journal of Environmental Quality, Volume 23. pp. 883-891.

Gosselin et al. (R. E. Gosselin, H. c. Hodge, and R. P. Smith), 1976. Clinical Toxicology of Commercial Products, fourth edition, Williams and Wilkins, Baltimore, Maryland.

Goyer, R. A., 1991. "Toxic Effects of Metals," in Toxicology: The Basic Science of Poisons, fourth edition, pp. 623-680, M. O. Amdur, J. Doull, and C.D. Klaassen, eds., Pergamon Press, New York, New York.

Hadjimarkos, D. M., 1968. Adv. Oral Biol., Vol 3, pp. 253-292.

Hadjimarkos, D. M., 1966. "Vanadium and Dental Caries," in Nature, Vol. 209, pp. 1137.

Harris et al. (W. R. Harris, S. B. Friedman, and D. Silberman), 1984. Journal of Inorganic Biochemistry, Vol. 20, pp. 157-169.

Hood, R. D., 1972. "Effects of Sodium Arsenite on Fetal Development," in Bulletin of Environmental Contamination and Toxicology, No. 7, p. 216.

Horst, W. J., 1988. "The Physiology of Manganese Toxicity," in Manganese in Soil and Plants, R.D. Graham, R.J. Hannam, and N.C. Uren, editors, Kluwer Academic Publishers, Boston. 
Horst, W. J., 1982. " Quick Screening of Cowpea Genotypes for Manganese Tolerance During Vegetative and Reproductive Growth, " Z. Pfanzenenaehr. Bodenk. Volume 145. pp. 423-435.

Hull, R. N., and G. W. Suter, 1994. Toxicological Benchmarks for Screening Contaminants of Potential Concern for Effects on Sediment-Associated Biota: 1994 Revision, ES/ER/TM-95/RI, U.S. Department of Energy, Oak Ridge National Laboratory, Oak Ridge Tennessee.

ICRP (International Commission on Radiological Protection), 1960. ICRP Publ., 2.

Ishinishi et al. (N. Ishinishi, K. Tsuchiya, M. Vahter, and B. A. Fowler), 1986. "Arsenic," in Handbook on the Toxicology of Metals, Volume II: Specific Metals, second edition, Elsevier Press Science Publishers B.V., Amsterdam, the Netherlands.

Kondakis et al. (X. G. Kondakis, N. Makris, M. Leotsinidis, M. Prinou, and T. Papapetropoulos), 1989. "Possible Health Effects of High Manganese Concentration in Drinking Water," in Archives of Environmental Health, Vol. 44, No. 3, pp. 175-178.

Krauskopf, K. B., 1979, Introduction to Geochemistry: McGraw-Hill, New York, 617 p.

Lagerkvist et al. (B. Lagerkvist, G. F. Nordberg, and V. Vouk), 1986. "Vanadium," in Handbook on the Toxicology of Metals, second edition, L. Friberg, G. F. Nordberg, and V. Vouk, eds., Elsevier Science Publishers, New York, New York.

Latarjet, R., 1992. "Radiation Carcinogenesis and Radiation Protection," in The Cancer Journal, Vol. 5, no. 1, pp. 23-27, January-February 1992.

Lauchli, A., 1993. "Selenium in Plants: Uptake, Functions, and Environmental Toxicity," Bot. Acta, Volume 106. pp. 455-468.

Lazo, T.,1994. "French Researcher Suggests Existence of a Threshold for Cancer Induction," The Health Physics Society's Newsletter, Vol. 22, no. 1, pp. 5-6.

Leach et al. (L. J. Leach, R. M. Gelein, B. J. Panner, C. L. Ylie, and C. C. Cox), 1984. The Acute Toxicity of the Hydrolysis Products of Uranium Hexafluoride (UFG) When Inhaled by the Rat and Guinea Pig, final report, ISS K/SUB-81-9039-3, NTIS DE84011539.

Lemly, A. D. and G. J. Smith, 1987. "Aquatic Cycling of Selenium: Implications for Fish and Wildlife," U.S. Fish and Wildlife Service, Washington D.C., Fish and Wildlife Leaflet 12.

Lindgren et al. (A. Lindgren, M. Vahter, and L. Dencker), 1982. "Autoradiographic Studies on the Distribution of Arsenic in Mice and Hamsters Administered ${ }^{74}$ As-arsenite or -arsenate," in Acta Pharmacology and Toxicology, No. 51, pp. 253-265. 
Long et al. (E. R. Long, D. D. MacDonald, S. L. Smith, and F. D. Calder), 1993. "Incidence of Adverse Biological Effects within Ranges of Chemical Concentrations in Marine and Estuarine Sediments," Submitted to Environmental Management October 15, 1993.

Lönnerdal et al. (B. Lönnerdal, C. L. Keen, J. G. Bell, and B. Sandstrom), 1987. "Manganese Uptake and Retention," in Nutritional Bioavailability of Manganese, C. Kies, ed., American Chemical Society, symposium series 354, pp. 9-20, American Chemical Society, Washington, D.C.

Marafante, E., and M. Vahter, 1987. "Solubility, Retentions and Metabolism of Intratracheally and Orally Administered Inorganic Arsenic Compounds in Hamsters," in Environmental Research, No. 42, pp. 72-82.

Marcus, W. L., and A. S. Rispin, 1988. "Threshold Carcinogenicity Using Arsenic as an Example," in Advances in Environmental Toxicology, Volume XV. Risk Assessment and Risk Management of Industrial and Environmental Chemicals, pp. 133-159, C. R. Cothern, M. A. Mehiman, and W. L. Marcus, eds., Princeton Scientific Publishing Co., New Jersey.

Maynard, E. A., and H. C. Hodge, 1949. "Study of Toxicity of Various Uranium Compounds When Fed to Experimental Animals," in Pharmacology and Toxicology of Uranium Compounds, National Nuclear Energy Services, Div. VI, Vol. 1, pp. 309-376, C. Voegtlin and H. C. Hodge, eds., McGraw Hill, New York, New York.

Medinsky et al. (M. A. Medinsky, R. G. Cuddihy, and R. O. McClellan), 1981. J. Toxicol. Environ. Health, Vol. 8, pp. 917-928.

Mena et al. (I. Mena, K. Horiuchi, K. Burke, and G. C. Cotzias), 1969. "Chronic Manganese Poisoning. Individual Susceptibility and Absorption of Iron," in Neurology, No. 19, pp. 1000-1006.

Meneely, G. R., and H. D. Battarbee, 1976. "Sodium and Potassium," in Nutrition Reviews, No. 8, pp. 225-235.

Merritt, R. C., 1971. The Extractive Metallurgy of Uranium, Colorado School of Mines Research Institute, Golden, Colorado, 1971.

Millar et al. (K. R. Millar, M. A. Gardiner, and A. D. Sheppard), 1973. New Zealand Journal of Agricultural Research, Vol. 16, pp. 115-127.

Morris, M. E., and G. Levy, 1983. "Absorption of Sulfate from Orally Administrated Magnesium Sulfate in Man," in J. Toxicol. Clin. Toxicol., 20:107-114.

Morrison et al. (G. M. P. Morrison, G. E. Batley, and T. M. Florence), 1989. "Metal Speciation and Toxicity," in Chem. Br., No. 25, p. 791. 
National Research Council, 1989. Recommended Dietary Allowances, tenth edition, National Academy Press, Washington, D.C.

National Research Council, 1980. Drinking Water and Health, Vol. 3, Safe Drinking Water Committee.

National Research Council, 1973. Medical and Biological Effects of Environmental Pollutants: Manganese, Committee on Biologic Effects of Atmospheric Pollutants, Division of Medical Sciences.

NCRP (National Council on Radiation Protection and Measurements), 1984. Exposures from the Uranium Series with Emphasis on Radon and its Daughter, NCRP Report No. 77, Bethesda, Maryland.

Oftedal, P., 1990. "A Holistic View of Low-level Radiation Effects in Biological Systems," in Canadian Journal of Physics, 68, pp. 974-978.

Opresko et al. (D. M. Opresko, B. E. Sample, and G. W. Suter), 1994. Toxicological Benchmarks for Wildlife: 1994 Revision, ES/ER/TM-86/RI, U.S. Department of Energy, Oak Ridge National laboratory, Oak Ridge, Tennessee.

Palisade Corporation, 1992. @RISK, Risk Analysis and Simulation Add-In for Lotus 1-2-3, Version 2.01, Newfield, New York.

Parkhurst et al. (D. L. Parkhurst, D. C. Thorstenson, and D. N. Plummer), 1980. PHREEQE - a computer program for Geochemical Calculations, U. S. Geological Survey, Water Resources Investigation 8-096, National Technical Information Services Report PB81-167-801, Springfield, Virginia.

Pennington, J. A., and J. W. Jones, 1987. "Molybdenum, Nickel, Cobalt, Vanadium, and Strontium in Total Diets," in Journal of the American Dietetic Association, Vol. 87, No. 12, December 1987, American Dietetic Association, Division of Nutrition and Division of Contaminants Chemistry, Center for Food Safety and Applied Nutrition, Food and Drug Administration, Washington, D.C.

Perry et al. (H. M. Perry, Jr., S. Teitlebaum, and P. L. Schwartz), 1955. "Effects of Antihypertensive Agents on Amino Acid Decarboxylation and Amino Oxidation," in Fed. Proc., Vol. 14, pp. 113-114.

Persaud et al. (D. Persaud, R. Jaagumagi, and A. Hayton), 1990. "The Provincial Sediment Quality Guidelines", Ontario Ministry of the Environment, Water Resources Branch, Toronto, Ontario.

Pershagen, G., and M. Vahter, 1979. Arsenic, Swedish Environmental Protection Board, Stockholm, Sweden.

Prister, B. S., 1969. GKIAE Report by Atomizdat, Moscow (Canadian translation AEC/TR/7178 (1970), and USCEAR Rep. A/AC.82/G/L 1298). 
Proescher et al. (F. Proescher, H. A. Seil, and A. W. Stillians), 1917. Am. J. Syph., Vol. 1, pp. 347-405.

Rai, D., and J. M. Zachara, 1984. Chemical Attenuation Rates, Coefficients, and Constants in Leachate Migration, Volume I: A Critical Review, prepared by Battelle Pacific Northwest Laboratories for EPRI, Palo Alto, California.

Rigaud et al. (O. Rigaud, D. Papadopoulo, and E. Moustacchi), 1993. "Decreased Deletion Mutation in Radiolabeled Human Lymphoblasts," Radiation Research, 133, pp. 94-101.

Robinson et al. (M. F. Robinson, J. M. McKenzie, C. Thompson, and A. L. Van Rijn), 1973. Br. J. Nutrition, Vol. 30, pp. 195-205.

Roseberry, A. M., and D. E. Burmaster, 1992. "Lognormal Distributions for Water Intake by Children and Adults, ${ }^{n}$ in Risk Analysis, Vol. 12, No. 1, pp. 99-104.

Rosenfeld, I., and O. A. Beath, 1964. Selenium, Geobotany, Biochemistry, Toxicity, and Nutrition, Academic Press, New York, New York.

Rosoff, B., and H. Spencer, 1964. Nature (London), Vol. 202, pp. 410-411.

Sanders, J. G. and R. W. Osman, 1985. "Arsenic Incorporation in a Salt Marsh Ecosystem," Estuarine, Coastal and Shelf Science, Volume 20. pp. 387-392.

Saric, M., 1986. "Manganese," Handbook on the Toxicology of Metals, Vol. II, pp. 354-386. L. Friberg, G. F. Nordberg, V. B. Vouk, eds., Elsevier, New York.

Schroeder et al. (H. A. Schroeder, M. Mitchener, and A. P. Nason), 1970. "Zirconium, Niobium, Antimony, Vanadium and Lead in Rats: Life Term Studies," in Journal of Nutrition, 100, pp. 59-68.

Schroeder et al. (H. A. Schroeder, J. J. Balassa, and I. H. Tipton), 1963. Journal of Chronic Diseases, Vol. 16, pp. 1047-1071.

Shadley, J. D., and J. K. Wiencke, 1989. "Induction of the Adaptive Response by X-rays is Dependent on Radiation Intensity," in International Journal of Radiation Biology, Vol. 56, no. 1, pp. 107-118.

Shannon, R. L., and D. S. Strayer, 1989. "Arsenic-Induced Skin Toxicity," in Human Toxicology, No. 8, pp. 99-104.

Sherman, R., 1987. Colorado Division of Wildlife, Montrose, Colorado, personal communication to Eloise Mulford, Jacobs Engineering Group Inc., Albuquerque, New Mexico, March 2, 1987.

Shleien, B., 1992. The Health Physics and Radiological Health Handbook, revised edition, Scinta, Inc., Silver Spring, Maryland. 
Smith et al. (D. P. Smith, J. H. Kennedy, and K. L. Dickson), 1991. "An Evaluation of a Naidid Oligóchaete as a Toxicity Test Organism," in Environmental Toxicology and Chemistry, Vol. 10, pp. 1459-1465.

Snyder, F., and W. E. Cornatzer, 1958. "Vanadium Inhibition of Phospholipid Synthesis and Sulphydryl Activity in Rat Liver, in Nature, Vol. 182, pp. 462.

Somerville, J., and B. Davies, 1962. Am. Health J., Vol. 54, pp. 54-56.

Stevens et al. (W. F. Stevens, W. Bruenger, D. R. Atherton, J. M. Smith, and G. N. Taylor), 1980. "The Distribution and Retention of Hexavalent ${ }^{233} \mathrm{U}$ in the Beagle," in Radiation Research, No. 83, pp. 109-126.

Sullivan et al. (M. F. Sullivan, P. S. Ruemmler, J. L. Ryan, and R. L. Bushhom), 1986. "Influence of Oxidizing or Reducing Agents on Gastrointestinal Absorption of U, $\mathrm{Pu}, \mathrm{Am}, \mathrm{Cm}$, and Pm by Rats," in Health Physics, No. 50, pp. 223-232.

Suter, G. W. and J. B. Mabrey, 1994. Toxicological Benchmarks for Screening Potential Contaminants of Concern for Effects on Aquatic Biota: 1994 Revision, ES/ER/TM-96/RI, U.S. Department of Energy, Oak Ridge National Laboratory, Oak Ridge Tennessee.

TAC (Technical Assistance Contractor), 1994a. "Unpublished Field Notes, Naturita, Colorado, Uranium Mill Tailings Site," unpublished report prepared by the TAC, Albuquerque, New Mexico, for the U.S. Department of Energy, UMTRA Project Office, Albuquerque Operations Office, Albuquerque, New Mexico, dated November 15 and 16, 1994.

TAC (Technical Assistance Contractor), 1994b. "Unpublished Field Notes, Naturita, Colorado, Uranium Mill Tailings Site," unpublished report prepared by the TAC, Albuquerque, New Mexico, for the U.S. Department of Energy, UMTRA Project Office, Albuquerque Operations Office, Albuquerque, New Mexico, dated June 15 and $17,1994$.

TAC (Technical Assistance Contractor), 1993. "Unpublished Field Notes, Naturita, Colorado, Uranium Mill Tailings Site," prepared by the TAC, Albuquerque, New Mexico, for the U.S. Department of Energy, UMTRA Project Office, Albuquerque Operations Office, Albuquerque, New Mexico, dated June 29 through July 1, 1993.

TAC (Technical Assistance Contractor), 1992. "Unpublished Field Notes, Naturita, Colorado, Uranium Mill Tailings Site," unpublished report prepared by the TAC, Albuquerque, New Mexico, for the U.S. Department of Energy, UMTRA Project Office, Albuquerque Operations Office, Albuquerque, New Mexico, dated September 29 and 30, 1992. 
TAC (Technical Assistance Contractor), 1991. "Unpublished Field Notes, Naturita, Colorado, Uranium Mill Tailings Site," unpublished report prepared by the TAC, Albuquerque, New Mexico, for the U.S. Department of Energy, UMTRA Project Office, Albuquerque Operations Office, Albuquerque, New Mexico, dated June 19 and $21,1991$.

TAC (Technical Assistance Contractor), 1990. "Unpublished Field Notes, Naturita, Colorado, Uranium Mill Tailings Site," unpublished report prepared by the TAC, Albuquerque, New Mexico, for the U.S. Department of Energy, UMTRA Project Office, Albuquerque Operations Office, Albuquerque, New Mexico, dated June 11,12 , and $14,1990$.

TAC (Technical Assistance Contractor), 1988. "Unpublished Field Notes, Naturita, Colorado, Uranium Mill Tailings Site," unpublished report prepared by the TAC, Albuquerque, New Mexico, for the U.S. Department of Energy, UMTRA Project Office, Albuquerque Operations Office, Albuquerque, New Mexico dated August 30 and $31,1988$.

TAC (Technical Assistance Contractor), 1986. "Unpublished Field Notes, Naturita, Colorado, Uranium Mill Tailings Site," unpublished report prepared by the TAC, Albuquerque, New Mexico, for the U.S. Department of Energy, UMTRA Project Office, Albuquerque Operations Office, Albuquerque, New Mexico dated June 9 and 11, 1986.

Tank, G., and C. A. Storvick, 1960. "Effect of Naturally Occurring Selenium and Vanadium on Dental Caries," in J. Dent. Res., Vol. 39, pp. 473-488.

Tipton et al. (I. H. Tipton, P. L. Stewart, and J. Dickson), 1969. Health Physics, Vol. 9, pp. 103-145.

Tracy et al. (B. L. Tracy, J. M. Quinn, J. Lahey, A. P. Gilman, K. Mancuso, A. P. Yagdinas, and D. C. Villeneuve), 1992. "Absorption and Retention of Uranium from Drinking Water by Rats and Rabbits," in Health Physics, Vol. 62, pp. 65-73.

Tseng, W. P., 1977. "Effects and Dose-Response Relationship of Skin Cancer and Blackfoot Disease with Arsenic," in Environmental Health Perspectives, No. 19, pp. 109-119.

Tseng, et al. (W. P. Tseng, H. N. Chu, S. W. How, J. M. Fong, C. S. Lin, and S. Yeh), 1968. "Prevalence of Skin Cancer in an Endemic Area of Chronic Arsenicism in Taiwan," in Journal of National Cancer Institute, 40, 3, pp. 453-463.

Unit, P., 1987. "Empidonax trailli extimus: An Endangered Subspecies," Western Birds, Vol. 18, pp. 137-162.

USGS (U.S. Geological Survey), 1979. Water Resources Data for Colorado, Water Year 1978, Vol. 3, Dolores River Basin \& Green River Basin, Denver Colorado. 
Van Zinderen Bakker, and J. F. Jaworski, 1980. Effects of Vanadium in the Canadian Environment, Ottawa, Canada, National Research Council of Canada, Associate Committee, Scientific Criteria for Environmental Quality.

Venugopal, B., and T. D. Luckey, 1978. "Chemical Toxicity of Metals and Metalloids," in Metal Toxicity in Mammals, Plenum Press, New York, New York.

Wallace, A. and E. M. Romney, 1977. “Roots of Higher Plants as a Barrier to Translocation of Some Metals to Shoots of Plants, "In: Biological Implications of Metals in the Environment, Proceedings of the Fifteenth Annual Hanford Life Science Symposium, Richland, Washington.

Water Information Center, 1973. Water Atlas of the United States, Geraghty-Miller-Van der Leeden-Troise, A Water Information Center Publication.

Waters, M. D., 1977. "Toxicology of Vanadium," in Goyer, R. A., Melhman M.A., ed. Toxicology of Trace Elements, Advances in Modern Toxicology, Vol. 2, pp. 147189, New York: Halsted Press.

Webb, J. L., 1966. Enzymes and Metabolic Inhibitors, Academic Press, New York, New York.

Weigel, F., 1983. "Uranium and Uranium Compounds," in Kirk-Othmer Encyclopedia of Chemical Technology, Vol. 23, third edition, pp. 502-547, M. Grayson, ed., John Wiley and Sons, New York, New York.

Weir et al. (J. E. Weir, Jr., E. Blair Maxfield, and E. A. Zimmerman), 1984. Regional Hydrology of the Dolores River Basin, Eastern Paradox Basin, Colorado and Utah, Water-Resources Investigation Report 83-4217, U. S. Geological Survey.

Welch, R., 1993. Uncompahgre Basin Resource Area, Bureau of Land Management, Montrose, Colorado, personal communication to Charles Burt, Jacobs Engineering Group, Inc., Albuquerque, New Mexico, dated May 27, 1993.

WHO (World Health Organization), 1988. Vanadium, Environmental Health Criteria 81, published under the joint sponsorship of the United Nations Environment Programme, the International Labour Organisation, and the World Health Organization, Geneva, Switzerland.

WHO (World Health Organization), 1981. Arsenic, Environmental Health Criteria 18, published under the joint sponsorship of the United Nations Environment Programme, the International Labour Organisation, and the World Health Organization, Geneva, Switzerland.

Will, M. E. and G. W. Suter, 1994. Toxicological Benchmarks for Screening Potential Contaminants of Concern for Effects on terrestrial plants: 1994 revision, ES/ER/TM-85/RI, U.S. Department of Energy, Oak Ridge National Laboratory, Oak Ridge Tennessee. 
Wu et al. (M. M. Wu, T. L. Kuo, Y. H. Hwang, and C. J. Chen), 1989. "Dose-response Relation Between Arsenic Concentration in Well Water and Mortality from Cancers and Vascular Diseases," in American Journal of Epidemiology, Vol. 130, no. 6, pp. 1123-1132.

Wrenn et al. (M. E. Wrenn, P. W. Durbin, B. Howard, J. Lipsztein, J. Rundo, E. T. Still, and D. L. Willis), 1985. "Metabolism of Ingested U and Ra," Health Physics, Vol. 48, pp. 601-633.

Yakawa, M., and M. Suzuki-Yasumoto, 1980. "Distribution of Trace Elements in the Human Body Determined by Neutron Activation Analysis," in Arch. Environ. Health, Vol. 35, pp. 36-44.

Yang et al. (G. Yang, R. Zhou, and S. Yin), 1989a. "Studies of Safe Maximal Daily Dietary Selenium Intake in a Seleniferous Area in China," I, in J. Trace Elem. Electrolytes Health Dis., Vol. 3(2), pp. 77-87.

Yang et al. (G. S. Yang, R. Zhou, and S. Yin), 1989b. "Studies of Safe Maximal Daily Dietary Selenium Intake in a Seleniferous Area in China," II, Relation Between Selenium Intake and the Manifestation of Clinical Signs and Certain Biochemical Alterations in Blood and Urine," in J. Trace Elem. Electrolytes Health Dis., Vol. 3(2), pp. 123-130.

\section{CODE OF FEDERAL REGULATIONS}

40 CFR Parts 141, 142, 143, National Primary Drinking Water Regulations-Sulfate; Proposed Rule, U.S. Environmental Protection Agency (1994).

40 CFR Part 192, Health and Environmental Protection Standards for Uranium and Thorium Mill Tailings, U.S. Environmental Protection Agency (1994).

40 CFR Part 300, National Oil and Hazardous Substances Pollution Contingency Plan; Final Rule, U.S. Environmental Protection Agency (1995).

\section{FEDERAL REGISTER}

60 FR 2854, Groundwater Standards for Remedial Actions at Inactive Uranium Processing Sites, final rule, U.S. Environmental Protection Agency, 11 January 1995.

\section{UNITED STATES CODE}

42 USC $\$ 7901$ et seq., Uranium Mill Tailings Radiation Control Act, November 8, 1978.

42 USC $\$ 7922$ et seq., Uranium Mill Tailings Remedial Action Amendments Act, November 5, 1988. 


\section{UNITED STATES CODE}

42 USC $\$ 7901$ et seq., Uranium Mill Tailings Radiation Control Act, November 8, 1978.

42 USC $\$ 7922$ et seq., Uranium Mill Tailings Remedial Action Amendments Act, November 5, 1988. 